\author{
HWS- 5967 \\ Specification For Fuels \\ Recycle Pilot Plant
}




\section{DISCLAIMER}

This report was prepared as an account of work sponsored by an agency of the United States Government. Neither the United States Government nor any agency Thereof, nor any of their employees, makes any warranty, express or implied, or assumes any legal liability or responsibility for the accuracy, completeness, or usefulness of any information, apparatus, product, or process disclosed, or represents that its use would not infringe privately owned rights. Reference herein to any specific commercial product, process, or service by trade name, trademark, manufacturer, or otherwise does not necessarily constitute or imply its endorsement, recommendation, or favoring by the United States Government or any agency thereof. The views and opinions of authors expressed herein do not necessarily state or reflect those of the United States Government or any agency thereof. 


\section{DISCLAIMER}

Portions of this document may be illegible in electronic image products. Images are produced from the best available original document. 
HWS -5967

SPECIEICATIONS FOR

FUELS RECYCLE PILOT PLANT

BUILDING 324

PROJECT CAH-916

November 15, 1962

Prepared by General Electric Co.

Conuturtion Engineexing \& Utilities Operation

Desing Encineering Operation
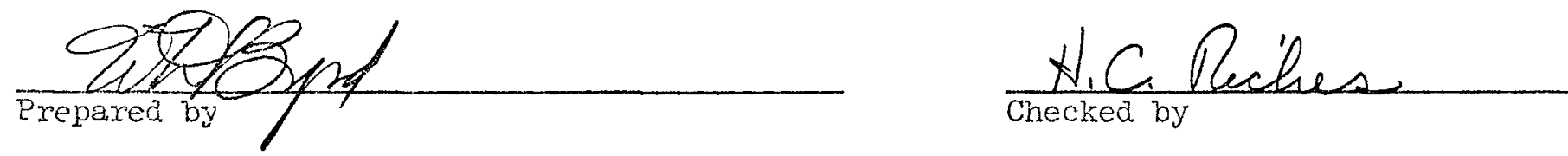

Design Evineering Operation
Corswation Engineering \& Utilities Operation
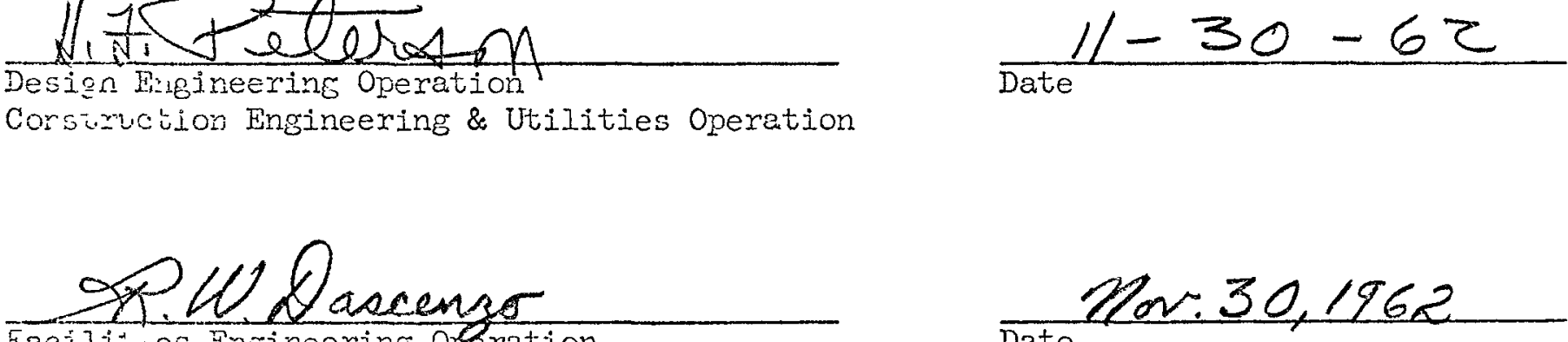

Encilivies Engineering oferation

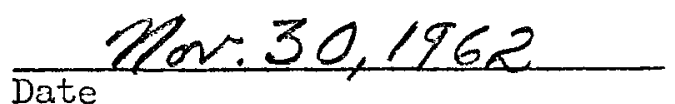

Ianforc Laboratories Operation

\section{NOTICE-}

This report was prepared as an account of work sponsored by the United States Government, Neither the United States nor the United States Atomic Energy Coming Commission, hor any of therr employees, nor any of their contractors, subcontractors, or therr employees,

makes any warranty, express or implied, or assumes any

legal liability or responsibility for the accuracy, com-

pleteness or usefulness of any information, apparat us,

product or process disclosed, or represents that its use

would not infringe privately owned rights. 
TABTE OF CONTENTS

\begin{tabular}{|c|c|c|}
\hline 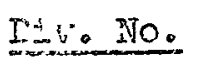 & Title & Page \\
\hline 空 & Excavating, Backfilling \& Grading & 1 \\
\hline$=1$ & Concrete \& Masonry & 5 \\
\hline $2 \pi$ & High-Density Concrete & 11 \\
\hline$\therefore$ & Structural Steel \& Miscellaneous Metal Items & 20 \\
\hline 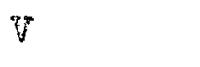 & Welding & 28 \\
\hline 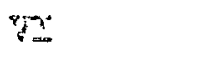 & Piping \& Plumbing & 32 \\
\hline 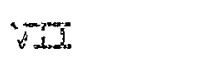 & Roof Decks \& Roofing & 84 \\
\hline PTI & Plaster \& Stucco Work \& Suspended Metal-Pan Ceiling & 89 \\
\hline \pm & Metal Wall Panesl \& Insulated Siding & 100 \\
\hline 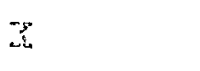 & Heating \& Ventilatin & 104 \\
\hline 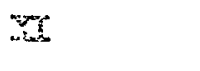 & Standard Doors, Windows \& Hardware & 175 \\
\hline 20 & Special Doors \& Shielding & 189 \\
\hline YII & Sprinkler System & 197 \\
\hline$x .7$ & Cranes̃ \& Hoists & 202 \\
\hline$r y$ & Elevator \& Dumbwaiter & 213 \\
\hline$x$ & Painting, Protective Coating \& Floor Covering & 224 \\
\hline XII & Electrical & 239 \\
\hline$x \sqrt{2} I$ & Substation \& Switchgear & 278 \\
\hline $2 \pi$ & Cormunication Systems \& Building Alarms & 295 \\
\hline$x:$ & Instmumentation & 303 \\
\hline$x y$ & Viewing Windows & 311 \\
\hline$x$ & Special Equipment \& Furnishings & 318 \\
\hline$\therefore I I I$ & Roads \& Paving & 332 \\
\hline sery & Exhaust Stack & 334 \\
\hline & $\begin{array}{l}\text { Appendix "A" } \\
\text { Appendix "B" } \\
\text { Appendix "C" }\end{array}$ & $\begin{array}{l}A-1 \\
B-1 \\
C-1\end{array}$ \\
\hline
\end{tabular}




\section{DIVISION I}

EXCAVATING, BACKFILLING, AND GRADING

\section{GENERAL}

1. SCOPE

This division of the specification covers all excavating, filling, backfilling, and grading for the Fuels Recycle Pilot Plant, Building 324, except

that required for roadways and the pariing lot.

2. EFEEERENCED STANDARDS AND SPECIFICATIONS

The standards and specifications listed below form a part of this specifica tion to the extent indicated by subsequents references.

2.1 AMERTCAN ASSOCIATION OF STATE HIGHWAY OFEICIALS (AASHO)

T180.57 Moisture-Density Relations of Soils Using a 10 Ib. Rammer and 18" Drop

TI47 054 Field Determination of Density of Soil in Place

\section{MATERIALS \& WORKMANSHIP}

\section{EXCAVATTING}

\subsection{FOOIINGS AND FOUNDATIONS}

a. Excavations will be made in predominantly sandy soil interspersed with strata of cemented gravel and small boulders up to approximately two feet in diameter.

b. All excavations for footings and foundation slabs shall be made to proper depth and width with adequate allowances made for forms and bracing. Bottoms of such excavations shall be level and true and free of loose materials.

c. Machine excavation for structures to bear on undisturbed earth shall be stopped 2 inches or more above the elevation of the bottom of the footing or base slab as show on the drawings. The remaining excavation to the required elevation shall be done by manual means.

d. II over-excavation occurs where footings or foundations are to be placed on undisturbed earth, it shall be corrected at the time of placing concrete by extending the concrete to undisturbed earth.

e. Excarated or other materials shall not be stored closer than 4 feet from the edge of the excavation and shall be so stored and retained 
3. EXCATATITYS

\section{I FOOTIUSS AND FOUNDATIONS}

e. (Continued)

as to prevent them from falling or sliding into the excavation, and

to prevent excessive pressure on the sides of the excavation.

f. Sides and siopes of excavations shall be maintained in a safe conditrior. by scaling, benching, or barricading. Excavations shall be mainiained free from standing water at all times.

g. Ali footings and foundations shall bear on undisturbed earth. Where footings and foundations are to bear adjacent to the edges of deeper excarations, the Contractor chall provide means for maintaining these bearing areas in the undisturbed condition. The Contractor shall furaish sketches, of the method he proposes to use to accomplish the shove requirement, to the Commission for approval one week before strarting the deeper excavations.

\subsection{PIPE TRENCHES}

9. All excavations for piping shall be true to line and grade as shown cri the arawings. They shall be of adequate width to permit handing of pipe and accessories and making necessary connections. They shall be of sufficient depth to permit the placement of a compacted sand cushion ( 4 inches minimum thickness) beneath pipe except where excavation ¿s in unåsturbed sand.

b. Shoring will be required for all trench excavations more than 4 feet deep in which the sides are sloped steeper than one horizontal to one yertical. Shoring shall be installed as excavation progresses and shall be removed as backfilling is accomplished.

c. Shoring and bracing shall be designed to withold all material and surcharge pressures the full depth of the trench.

a. Pipe trenches shall be maintained free from standing water at all tirnes.

\section{BACKEITLINC}

4.1 GENESAE

a. For the purposes of this specification, the term backfilling shall refer to the placement and compaction of soil whether excavated at the site or borrowed from other locations.

b. Only selected material shall be used for backfill. Frozen particles or iumps, vegetable matter or trash shall not be used in any backfill. Backfill shall not be placed on frozen ground. 
4. BACKFITITING

4.1 GENERAI, (Continued)

c. Backfilling by or with sluicing or flooding with water will not be permitted. This requirement shall not prohibit the saturation and vibration of the sand cushion beneath underground pipelines.

d. Borrowed material for fill and backfill shall be obtained at the borrow pit specified in the Special Conditions. Backfill shall be placed and compacted uniformly on both sides of walls to prevent unbalanced load ing.

\subsection{MON-IOAD-BEARING BACKFIII,}

a. Material for non-load-bearing backfill shall contain no rocks larger then 8 inches in any dimension.

b. Mon-load-bearing backfill shall be placed in layers not more than 12 inches thick, loose measurement. Each layer shall be compacted full width, by at least two passes of a vibratory type compactor.

\subsection{PIPE TRENCH BACKFIII}

8. Backfill material under the haunches of the pipe, around the sides, and up to a point one foot above the top of the pipe shall be sand, or excavated material containing no stones or gravel larger than $\frac{1}{2}$ inch in greatest dimension. Any over excavation of pipe trenches shall be corrected by bringing the ditch up to proper profile with load-bearing backfill, prior to laying pipe.

b. Backfill for pipe and conduit trenches, above a point one foot above the top of the pipe, shall conform to the requirements stated in Section 4.2 above for non-load-bearing backfill, except in those low cations where loadbearing backfill is required. Backfill shall not be piaced over joints in underground lines until pressure testing of the line has been completed.

c. The sand cushion placed in pipe trenches for underground pipelines shall be material complying with paragraph $4.3 a$, above. The material shail be compacted by two passes of a vibratory type compactor prior to laying pipe.

d. Feavy construction equipment shall not pass over buried lines until at least 3 feet of compacted backfill has been placed over the line. 


\section{BACKFILIING (Continued)}

\subsection{LOAD JEARING BACKFILI}

a. Materials for load-bearing backfill shall contain no rocks larger than three inches in any dimension.

b. Load-bearing backfill shall be placed as follows:

(I) Materials shall be placed in layers not more than 8 inches thick, loose measurement. Each layer shall be uniformly spread, and compacted to the required density shown below.

(2) Loadmearing backfill shall be compacted with a vibratory type compactor until 95\% of the "maximum density" is achieved. The "maximum density" shall be determined by the method specified in AASHO Designation: TI80, Method D. The compacted backfill shall be tested by the method specified in AASHO Designation: T147.

c. The Contractor shall submit, in writing, a proposed method for compacting load-bearing backfill, for approval by the Commission. The Contractor will be required to demonstrate by physical test at the site that the proposed method will provide the degree of compaction specified in paragraph $b$ (2) above, at least five working days before starting backfill work.

d. When a specific procedure has been agreed upon by both the Commission and the contractor it shall be followed in compacting all load-bearing backfill.

e. All fill and backfill inside the foundation lines of the building shall be load wearing backfill. All fill or backfill placed outside the building lines but under concrete slabs, walks, and basement ramp shall be load-bearing backfill. Other specific locations requiring loadbearing backfill shall be as shown on the drawings.

\section{FINISH GRADING AND STABILIZATION}

a. As a last item of work, the area surrounding the building shall be graded to the new contours shown on drawing H-3-20152. The area shall be raked free of large surface stones, trash, forms, chips and other debris.

b. The finish graded areas shall be covered with a 3 inch thick course of 2" nilnus pitwrun gravel. Finish graded areas shall extend to the limits ixificed by the contour lines on drawing $\mathrm{H}-3-20152$. 


\section{DIVISION II}

\section{CONCRETE AND MASONRY}

GENERAI

1. SCOPE

This division of the specification covers all masonry work and structural concrete work, other than high density concrete and the exhaust stack, for the Fuels Recycle Pilot Plant, Building 324. High-density concrete work is specified in Division III. The Exhaust Stack is specified in Division XXIV.

\section{REFERENCED STANDARDS AND SPECIFICATIONS}

The standards and specifications listed below form a part of this specification to the extent indicated by subsequent references.

\subsection{AMERICAN SOCIETY FOR TESTING AND MATERIALS}

ASTM A82-6IT Cold Drawn Steel Wire for Concrete Reinforcement

ASTM C33-61T Concrete Aggregates

ASTM C90-59 Hollow Load-Bearing Concrete Masonry Units, Grade A

ASTM C94-6I Ready-Mixed Concrete

ASTM C144-52T Aggregate for Masonry Mortar

ASTM C150-61 Portland Cement

ASTM C207-49 Hydrated Lime for Masonry Purposes, Type N

\subsection{ELDERAL SPECIFICATIONS}

SS-S-1590, Sealing Compound; Cold Application Mastic, For Joints in Concrete ITT-C-598 Compound; Caulking, Plastic; Type II

\subsection{HANFORD STANDARD SPECIFICATIONS}

HW-4798-S, Rev. 5 Placing Reinforced Concrete

\subsection{AMERICAN STANDARDS ASSOCIATION (ASA)}

ASA 116.1 - 1960, Polysulphide - Base Sealing Compounds For the Building
Trades

\section{SIBMISSION OF DRAWINGS}

Prior to fabrication, the Contractor shall submit complete reinforcing fabrication and placing drawings to the Conmission for approval. Drawings shall be submitted in accordance with the requirements stated in the Special Conditions. 


\section{MATERIAIS}

4. CONCRETTE

a. Structural portland cement concrete shall conform to the requirements of ASTM C94. Fine aggregate shall be washed natural sand conforming to the requirements of ASTM C33.

D. Cement for structural concrete shall conform to the requirements of ASTM CI50, Type II.

c. Maximum size of coarse aggregate shall be 1-1/2". Coarse aggregate shall be crushed stone or crushed gravel conforming to the requirements of ASTM C33. Coarse aggregate for stair treads and landings shall be $3 / 4$ " max.

a. Stmuctural concrete shall have a minimum allowable compressive strength of 3000 psi at 28 days.

e. An air-entraining admixture will be permitted in structural concrete except in walls or slabs 24 inches or more in thickness. Where an air entraining adrixture is used the air content of the concrete shali be within the range 3 to 6 percent.

f. Slump of concrete at the time of deposit in the forms shall conform to the following:

\section{Type of Stmucture}

Floors and slabs

Walls: 6" to $10^{\prime \prime}$ thick

Walls: $10^{\prime \prime}$ to $18^{\prime \prime}$ thick

-Walls: thicker than 18"

Tops of walls, piers, curbs and parapets

Other parts
Max. Slump in Inches

3

4.

3

2

2

3

\section{CONCRETE BLOCKS}

a. Concrete blocks shall be $8 \times 8 \times 16$ or $4 \times 8 \times 16$ nominal size as shown $\mathrm{cn}$ the drawings, uniform dusty-pinis colored, hollow, load-bearing concrete blocks conforming to the requirements of ASTM C90, Grade A.

b. Single core blocks and specials for jambs, comers and lintels shall be of the same material as full-size blocks and shall be matching color. 
5. CONCREIE BLOCKS (Continued)

c. Pattern blocks as shown on drawing $\mathrm{H}-3-20175$, shall be Layrite Concrete Products Company "Shadowal", or approved equal, dusty-pink in color.

6. MORPAR

Ingredients for mortar shall meet the following specifications:

. Portland Cement shall conform to the requirements of ASTM C150, Type II.

b. Lime shall conform to the requirements of ASTM C 207, Type N, Normal Hydrated Lime.

c. Aggregate shall conforn to the requirements of ASTM C144.

3. Water shall be clean and free of organic or vegetable matter, acid, aidgli or other deleterious substances and shall be handled in clears containers.

7. FORMS AND REINFORCING

Forms and reinforcing steel for structural concrete shall meet the requirements specified in Hanford Standard Specification HW-4798-S.

8. TOTDE MATERTAIS

a. Expansion joint filler material and waterstops for construction joints below grade shall conform to the requirements specified in Hanford Standard Specification HW-4798-S.

b. Sealer for expansion joints in concrete and masonry in the administration area, laboratory area, Cold Shop and slabs outside the building shaII conform wo whe requirements of Federal Specification SS-S-159 b.

c. Sealer for expansion joints in concrete and masonry in all areas other then those specified in paragraph $b$. above shall be a polysulphide rubbex compound conforming to the requirements of ASA 116.1 .

d. Caulking compound shall be a non-asphaltic, gray colored material conforming to Federal Specification TT-C-598, Type II (knife grade).

9. MASONBY ANCHORS AND REINFORCING

a. Masonry reinforcement shall be fabricated from steel wire confoming to the requirements of ASTM A 82 . Finish shall be bright basic. 
9. MASONRY ANCHORS AND REINEORCING (Continued)

b. Reinforcement shall have two No. 8 gauge or three No. 9 gauge longitudinal wires. Cross ties shall not be smaller than No. 12 gauge. "Durowall."; Carter-Waters Corp. "Blok-Mesh"; and AA Wire Products Co. "Blok-Lok" are examples of products conforming to this specification.

c. Masonry anchors, for attachment of masonry walls to concrete walls, shall be 16 gauge galvanized steel, dovetail design with 20 gauge galvanized dovetail anchor \$lots. Gateway Engineering Co. "Beehive" anchor slots with "Queen-Bee" anchors; Cleveland Steel Specialty Co. "Cleveland" anchor slots and anchors' and Dayton Sure-Grip \& Shore Co. No. FI7 Anchor Slot and No. F2O Anchors are examples of products complying with these specifications.

\section{ABRASTYE STAIR NOSTNGS}

Stair nosings shall be $3^{\prime \prime}$ wide, 1/4" thick extruded aluminum with five abrasive filled ribs (top surface flat). Nosing shall drop approximately I $1 / 8$ inch below tread. Abrasive nosings shall be American Abrasive Metals Co. "Altred" No. 132 A; Wooster Products, Inc. "Super-Grit" No. I32; Miscellaneous Mfg. Corp. Style F-4; or approved equal.

\section{SURFACER FOR MASONRY TO BE PAINTED}

Surfacer material for masonry walls which are to receive paints or coatings shall be a latex resin-hydraulic cement mixture which is adaptable for application with a steel or rubber trowel or rubber squeegee. SherwinWilliams Co. "Loxon" Latex Concrete and Carboline Co. No. 3340 "Surfacer" are examples of the type material required.

\section{WORKMANSHIP}

\section{PLACING CONCRESTE}

a. All forming, reinforcing, placing, finishing, curing and repairing of concrete shall conform to the requirements specified in Hanford Stardard Specification HW-4798-S.

t. If sheet piling is used to retain the undisturbed earth surrounding the excavations for the Wet Basin and other pits lower than elevation (-) 10'-0", the piling may be used as the outer form for concrete walls, provided the full wall thickness is maintained. If sheet piling is used it shall not be renoved.

c. Concrete finishes shail be as follows:
(I) Formed surfaces to be exposed to earth backfill
Finish 
$\therefore$ (Gontinied)

(2) Exterior formed surfaces to be exposed to the

Finish westher

(3) Formed surfaces to be painted with conventional

F. $=3$

$\mathrm{F}-4$ (or latex-cement

$\mathrm{F}-3$ surfacer).

(4) Eare concrete interior walls

(5) Formed surfaces to be covered with special protective coatings

(6) informed surfaces of exterior entrance slabs, ramps and walks

(7) Surfaces of interior floors
$\mathrm{F}-4 *$

$\mathrm{U}-5$

U-3

Whe time limit for completion of $\mathrm{F}-4$ finish, specified in Inv-4798-S, shall be strict.ly adhered to.

d. Wherever fresh concrete is to be bonded to set concrete the existing corrate shall be coated with an epoxy resin bonding compound of the type specified in Hanford Standard Specification HW-4798-S.

a. Where transfer mechanisms pass through concrete walls, the housing shell be blocked intemally to maintain the close tolerances required.

f. "Pour slips" shall be prepared by the Contractor to show the specific portion of the structure to be placed, the concrete mix data, the air contient and the required slump range. Commission approval will be required on each "pour slip" prior to ordering, delivery of or mixing concrete. "Pour-slip" forms will be furnished by the Commission.

g. Weterstops, as specified in Hanford Standard Specification HW-4798-S, shall be used in all construction joints below elevation $0^{\prime}-0^{\prime \prime}$ and in 11 vertical construction joints; at all elevations.

r. SFetions of concrete walls and slabs shall not be placed in lengths greater than $40 \mathrm{L.F}$. in any single "pour". Where noted on the drawings, flocr slabs shall be placed in alternate sections to reduce orexili shrinkage. These limitations shall not apply to heavy walls con sivis of process cells where monolithic pours are required.

2. Dry cemert shall not be used to expedite setting of fresh concrete.

a. AII. comers, wa.1-to-wQII and wall-to-floor slabs shall be chamfered $3 / 4$ incines.

13. CONSTRICIING MASONRY

13.1 MTXING MORIAR

Mortar ingredients: shall be proportioned as follows: 


\section{CONSTRJCTING MASONRY}

13.I MIXING MORTAR (Continued)

1 part (minimum) portland cement

$1 / 4$ part to $1 / 2$ part hydrated lime

Dry loose aggregate shall be not less than

$2 \frac{1}{2}$ times nor more than 3 times the sum of

the volumes of cement and lime used.

Mcrtar msterials shall be accurately measured by volume and thoroughly mixed in 8 batch mixer. Ingredients shall be thoroughly mixed while dry tefore adding water. Mixing shall continue for at least 3 minutes sfter a.j irgredients have been added. Mortar shall be mixed in guntities not greater than are required for use within one hour. Rew termoring of mortar will not be permitted. The use of salt or other asti-freeze sdmixtures will not be permitted. Powdered color shall be adjed to tint mortar to match block color except where block walls are ro be painted.

\subsection{ININT BLOCKS}

कo Blooks shall be surface dry when laid.

b. Exterior walls shall be laid in horizontal stack pattern. Interior Walis shall be laid in horizontal stack pattern.

c. Blocks shaII be laid with shell mortar bedding. Mortar joints shall be struck off flush, and after the mortar has taken an initial set, the joint mortar shall be compressed with an oval-faced grooving tool except at special patterns. Joints in pattern recess shall be tooied fiush.

d. Yorizontal reinforcing shall be placed in altemate courses or at every third course as show on the drawings.

e. Masonry walls abutting concrete walls shall be attached by the use of anvetail anchors and anchor slots. Dovetail anchors shall be set in alternate courses of the masonry.

f:- Where filling of block cores is specified on the drawings, mortar shail be "rodded" solid. Block cores shail be filled as each course of blooks is laid.

E. Where block walls are to be painted with enamel or special protective coaijigs ( see drawings H-3-20174-75) they shall be given a coat or latexcement surfecer, as specified in section 11 above, to fill voids, holes and recessed joints. Block walls to receive rubber-base paint or silicone sealer shall not be surfaced. 


\section{DIVISION III}

HIGH-DENSITY CONCRETE

GENERAI

1. $\quad 860 \mathrm{gz}$

This aivision of the specifications covers all high-density concrete (jvar 160 Ib./cu ft.) for the Fuels Recycle Pilot Plant, Building 324.

2. PIANT AXD EQUIPMENT

The piat and eguipment propased by the contractor for use in storage if agseregates asd preparation and deivivery of high-density concrete and grut shall be subject to approval of the Commission. Such facilities Qmal1 male available for inspection by the comission at varying smerais during the period of preparation of high-density concrete.

\section{KEFERENYED STANDARDS AND SPECIFICATIONS}

Tine sindards and specifications listed below form a part of this specificstios to the extent indicated by subsequent references.

\subsection{AMERICAN SOCIEIYY FOR TESTING AND MATERIAIS}

\begin{tabular}{|c|c|}
\hline ASTM AI5-58T & Billet-Steel Bars for Concrete Reinforcement \\
\hline ASTM C $33-51 T$ & Concrete Aggregates \\
\hline ASTM C $39-61$ & $\begin{array}{l}\text { Test for Compressive Strength of Molded Concrete } \\
\text { Cylindexs }\end{array}$ \\
\hline A.STM C94.6I & Ready-Mixed Corcrete \\
\hline ASTR CIZ7-59 & Specific Gravity ard Absorption of Coarse Aggregate \\
\hline ASTM C138-2 & $\begin{array}{l}\text { Weight Per Cubic Foot, Yield and Air Content of } \\
\text { Concrete }\end{array}$ \\
\hline ASTM C142-55T & Clay Lumps in Natural Aggregate \\
\hline ASTM CI43-58 & Slump of Pcrtiand Cement Concrete \\
\hline $\operatorname{ASTM} C 230.61$ & Fortland cement \\
\hline ASTM CI 72.54 & Sampling Fresi Concrete \\
\hline
\end{tabular}

\subsection{GATFORD STANDARD SEECIFICATIONS}

IN 479 P. S, Rev. 5 Placing Reinforced Concrete

4. FORTIAND CEMENT

to Gyest for higk-density concrete shall be low alkali, non-airestraining, portland cement conficrming to ASTM Cl50, Type II. 
4. PORTLAND CENENT (Continued)

b. The Contractor shall furnish mill test reports to the Commission, Shoring brand, date of manufacture and source of the cement furnished, pricr to the placement of high-density concrete.

5. CONORETE AGGREGATES

5.1 GENERAI

a. Aggragates for high-density concrete and grout shall be a mixture \& Mignetite and Ilmenite and shall confcrm to the requirements of ASTM Designation: C33 for soundness, impurities and methods of samping and testing. Ilmenite content shall not be more than $5 \%$ of toteis.

5. Ageregates shall have properties which conform to the following requirenents:

Mirimum percent iron at $100 \mathrm{C} \ldots \ldots \ldots \ldots 5$

Mirimum value of specific eravity ......... 4.5

Maximum percent water absorpticn ......... 2.0

Specific gravity shall be the Bulk Specific Gravity (saturated, sureacedry basis) as defined in ASTM Designation: C127:

c. Certiffications of aggregates properties shall be furnished to the Cormission prior to highodensity concrete placement.

\subsection{FINE AGCREGATE}

a. Tre fireress modulus of fine aggregate shall be within the range 2.3 t. 3.2 .

t. Fire aggregate shall meet the following gradation requirements:

Amounts passing sieve size (percent by weight)

Noninal Square

Sieve Size

Percent

$3 / 8$

No. 4

No. 8

No. 16

No. 30

No. 50

No. 100

NC. 200

100
95 to 100
80 to 100
50 to 85
25 to 60
10 to 30
2 to 10
0 to 5




\subsection{COARSE AGGREGATE}

a. Coarse aggregate shall meet the following gradation requirements:

Amounts passing sieve size (percent by weight)

Nomiral Square

Sieve Size

$\frac{\text { Percent }}{100}$
95 to 100
60 to 85
35 to 70
20 to 50
10 to 30
0 to 5
0

\section{WATER AND ADMTXTURES}

a. Water for high-density concrete shall be clean and free from injurious ancunts of oil, acia, alkali, organic matter or other deleterious subgrtances.

b. The dexsifying and retarding agent shall be "Plastiment" as produced by the Sika Chemical Co., or an approved equal.

c. other admixtures, de-air-entraining agents, or corrective additives, tor axy purpose, shall be used only with the written approval of the Cormission.

\section{FEINTORCIVG STEEL}

a. Uriess specified otherwise, steel bar reinforcement shall be intermediate Erade, deformed bars conforming to ASTM Designation: Al5.

b. Reinforcing steel shall be free of bends not required by the drawings and shail be properly identified. Reinforcing steel shall be free of rust scale and loose mill scale, grease, paint, ice or any other substarce that would reduce or destroy the bond.

\section{WORKMANSHIP}

\section{STORACE OF MATERIAIS}

a. Cement shall be stored in a continuously dry environment. Broken saciss of cement or sacks containing partially solidified material shall not hat used. 


\section{STORACE OF MAIERIAIS (Continued)}

b. AlI aggregates covered by this specification shall be handled and stored in a manner to prevent:
(1) loss of fine sand,
(2) costamination by foreign material,
(3) aggregate breakage, and
(4) segregation.

c. Aggregates shall be stored at the site of the batch plant in approved containers, bins, heavy sacks, or if obtained in bulk, it shall be stsmed in a manner to prevent inclusion of dirt and other foreign maiter. Aggregates shall be covered with tarpaulins or plastic sheetirg yrtil used.

d. Concrets piacement equipment shell be thoroughly washed and cleared before and after each concrete pour is made.

9. COMPOSTTION OF CONCRETE

a. High-jensity concrete shall be composed of portland cement, water, f'ine and coarse aggregate and a densifying agent. High-density corcrete sha.l have a compressive strergth of at least $3000 \mathrm{Ib}$. per sq. irich at 28 days and a dry density of not less than $228 \mathrm{lb}$. per cubic foot.

b. Folowing is a guide for determining mix constituents:

$\mathrm{Ib} \cdot / \mathrm{Cu} \cdot \mathrm{Ft}$.

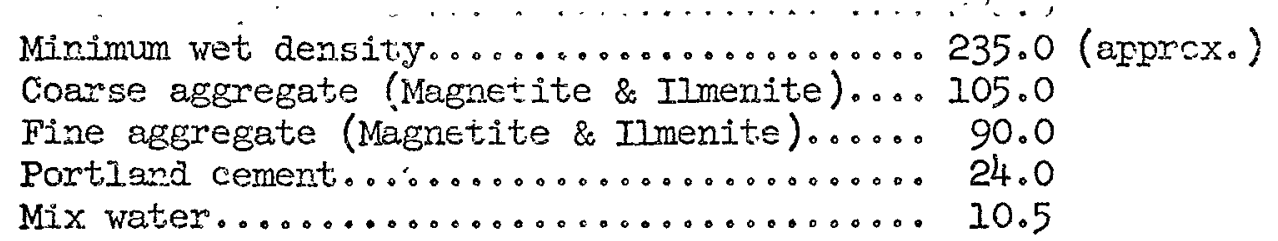

These mix data are based upon laboratory conditions and may require modification in the field to provide concrete of the required strengtr \pm ri density axd placing and hancling qualities. The Contractor may propose civarges in the mix design to imprcve hardling and placing qualities; however, any changes to the mix design shall be approved in writing by the Commission prior to such change.

c. Ineredients lised for batching concrete shall be mixed in proportions that will provide a workable consistency, minimum segregation during ivarding, and as high a density as is obtainable with the specified heary aggregates furnished on the job. The amourit of mix water used shall. be the absolute minimum consistent with job conditions. Slumps shall be within the range 1." to 3". Slump tests shall pe made in accordaree wits ASTM Designation: C. 143 . 


\section{COMP $2 S I T I O N$ OF CONCRETE (Continued)}

d. The wat dexsity of the concrete shall be determined in accordarse With ASTM Desigration: C138 and shall not be less than the minimum valus listed ix paragraph $\mathrm{b}$. above. The air content of concrete shall rot exceed 3 percent. Tests shall be made at least every two beros by the Commission during ail concreting operations to determine air contert and wet density.

e. Proior to job mixing of a partioular type of concrete a trial batch shall be made under field conditions by the contractor in order to cunfirm the properties and adequacy of a particular mix design and to prepare a set of six compression cylinders. (See Section 15 bel.Cw and Paragraph 18, ASTM Desigration C94 for required data and prceedures.) The Contractor shail notify the Commission of scheduled dates for preparing trial batches at lesst 10 wcrking days befors plasarent of rigkndensity conereto is to begin.

\section{HTGH-DEYSITY GROUT}

a. Gevt for use with high-density corcrete shall be composed of 3 parts cf fine aggregate and 1 part portiand cement.

b. Five aggregate shall be of the type specified in Section 5 above and shall anest the following gradation requirements:

\begin{tabular}{lc} 
Amovurits passing sieve size (percent by weight) & \\
$\begin{array}{ll}\text { Nominal Square } \\
\text { Sieve Size }\end{array}$ & Percent \\
\hline No. 16 & 100 \\
No. 30 & 65 to 90 \\
No. 50 & 30 to 50 \\
No. 100 & 10 to 30 \\
No. 200 & 0 to 5
\end{tabular}

Toe fireness modulus of fine aggregate for grout shall be within the raxge 1.30 to 1.90 .

11. BATCHINC AND MTXING REQUIREMENTS

a. Cement snall he measured by weight or by $941 \mathrm{~b}$. bags. When cemext is weighed it shall be done on a scale serarate from that used for cther rat srials. When cement is measured in bags, no fraction of a bag shall. be rised uriless weighed.

b. Aggregate shall be measured by weight. Batch weights shall be bastd on dro materials and shall be the required weights of dry materials plis 
11. BATCHTNC AND MIXING REQUIREMENTS

b. (Continued)

the total weight of moisture (both absorbed ard surface water) contained in the aggregate.

e. Water shail be measured by volume or weight.

d. Powdered admixtures shall be measured by weight, and liquid admixtures $b_{c} r$ weight or volume, within a limit of accuracy of 3 percent. Mchanical dispensing equipment shall be used for adding densifying agerts. These devices shall be kept free from sludge and accurately saibrated at all times. Airoertraining admixtures shall not be nssd in highodensity conerete.

\section{MIXINT TIME}

a. The mixing time shall be determined at the time the trial batches are made. In general, the mixing time shall not be less than $1-1 / 4$ minuises for each batch and shall be measured from the time that all solid materials are in the mixer drum, provided that all the mixing water shall be introduced before one quarter of the mixing time has elapsed. Coricrete consisting of aggregate inadequately mixed or lacking is mortar coating shall be rejected. Remixing or retempering shall rot be permitted.

b. The mixing periods specified are predicated on control of the speed of rotation of the mixer and of the introduction of the materials, incluaing water, into the mixer. The mixing time may be increased when in the opinion of the Commission, the charging and mixing operation fails to result in the required uniformity of composition and consistercy of the concrete or when test samples of concrete taken from three lecations, such as front, center, and back of the mixer, show a difference of more than 10 percent in the sand-cement or water-cement ratios.

c. The mixer shall revolve at a uniform speed for a minimum of twelve revoiutions after all materials have been placed in it. The mixer siall not be charged in excess of its safe capacity depending upcn the densitg of the mix, nor shall it be operated at a speed in excess if that recomended by the manufacturer. cyer-mixing requiring alditions cf water to preserve the consistency will not be permitted. Siculd the mixer produce concrete not in comformance with this specificaticn, as determined by the Commission, additional concrete Irrom that machine will not be accepted until the equipment has beer put in correct operating condition. 
a. If the Commission permits concrete piacement when the atmospheric temperature is below $40 \mathrm{~F}$, either aggregates or water, or both, as inay be necessary, shall be heated with steam coils or other approved devices. Materials contairing frozen lumps, ice or sr.w swail zot be allowed to enter the mixer. When it is necessary to heat concrete, temperatures shall be cortrolled so that they are rot less than $50 \mathrm{~F}$ and not above $70 \mathrm{~F}$.

b. The use of salts, chemicals or other foreign materials in the mix to zower the freezing point of concrete is proinibited.

c. Hamixtures intended to accelerate the hardening of concrete or produce highen than normal strengths at early periods shall be permitted only upon written approval from the Comission and then onis is approred percentages.

14. DELIVERY OF CONCRETE

a. Coswete shall be delivered to the site of placement in a thoroughy rixixea and uniform mass.

5. The elapsed time from the time cement is introduced into the mix uxil the concrete is discharged irto the forms shall not exceed ore bour. The maximum time concrete shall stand in non-agitating equifmant shall be 30 minutes.

c. Thuk mixers or agitators shall provide slow agitation of the concrete dus ing trassit. Bodies of nommatating equipment shall be smocth, watertight, metal containers equipped with gates that will permit control of the discharge of concrete. Watertight covers shall be provided for protection against the weather when required. All wash vater shal? be removed from mixers or transportation equipment before coccrete is piaced ir this equipment.

3. Water shall not be added tc the concrete after it leaves the stationary mixer, uniess approved otherwise in writing by the Comission.

e. Ihe slump of high-density concrete shall be determined in accordance with the requirements of ASTM Desigration: Cl+3. Unless specified aifeerenty on the drawings, slump at the time of placement shall be a.s foilows:

$$
\begin{aligned}
& \text { Horizontal slabs \& walls } 12^{\prime \prime} \text { to } 36^{\prime \prime} \text { thick }-2^{\prime \prime} \text { to } 3^{\prime \prime} \\
& \text { Walis thicker than } 36^{\prime \prime} \\
& \text { - } 1^{\prime \prime} \text { to } 2^{\prime \prime}
\end{aligned}
$$

¿Wher the ambient temperature is $85 \mathrm{~F}$ or highex; or under conditions cuntributing to quick stiffering of the concrete; or when the temperature of the concrete is $85 \mathrm{~F}$ or above, the time between the introduction of 
f. (Continued)

the cement to the aggregates and discharge into the forms shall rot exceed 45 minutes.

\section{PLACENEENT OF CONCRETE}

a. Forming, reinforcing, handling, preparation of existing surfaces, firsshing, curing and repairing cf concrete shall be in accordance with the requirements of Hanford standard specification HW-4798 5 , except as modified herein.

b. SEgregation of mix ingredients shall be prevented during handing and plarement procedures. The forms shall be completely filled with cor crete. There shall be nc vcids beneath embedded items or in remote corners of the forms and the composition of the concrete shall be uniform throughout the pour.

c. High-density concrete shall be vibrated at the time of placement in the forms in accordance with the requirements of Section 8.7 of HW-4798-S. Three workable vibratcrs shall be at the concrete pour before concrete placement in forms is started. One of the three vibrators shall be retained as a spare. High-density concrete shall be revibrated in accordance with the provisions of section 16 herein.

d. Vertical construction joints in high-density concrete shall contair a waterstop of the type specified in HW-498-S. Vertical constructior. joints shall contain a key one third the width of the section being placed and not less than 4 inches in depth.

€. Pours of high-density concrete shall be limited to 12 feet in height.

f. "Pour slips" shall be prepared by the Contractor for high-density concrete and the same requirements stated in Division II shall apply.

g. High-density concrete shall be water cured continuously for a period of at least 14 days.

\section{RE-VIBRATION}

a. Highodensity concrete shall be vibrated completely a second time beginning so sooner than one hour after placement in the forms. The optimum time after placemert for revibrating occurs when the vibrator will just sink into the concrete of its own weight. Sufficient vibration shall be applied to cause the concrete mass to become plastic again and to remove entrapped air and bleed water. 


\section{RE -VIERATION (Continued)}

b. Tre method and extent of revibration shall meet the approval of the Comission. Revibration shall be accomplished using imersionotype vibrators.

c. The maximum pour height for a particular pour shall be limited to 12 feet. To revibrate previously placed layers of fresh concrete it is permissible to (a) interrupt the pcur temporarily and revibrate to a maximum depth of $4 \mathrm{ml} / 2$ feet, or (b) place succeeding layers of concrete at approximately two hour intervals and then vibrate the top and bottom layers in such a manner that each bottom layer is revibrated in accordarce with the above requirements. Ir either case, the maximum depth of interraio vibrator penetration shall be $4 \mathrm{ml} / 2$ feet.

\section{TEST SFECIMENS AND CONTROL DATA}

a. Specimens of the concrete incorporated in the work will be taken and tested by the Comission in accordance with ASIM Designation: C172. A rinimum of one set of three compressive strength cylinders from each 100 cubic yards or fraction thereof for each structure, or each day's pour for each structure, whichever is less, will be taken. Test specimens and cylinders shall be cured and tested in accordance with ASTM Designation: C39. The test result shall be the average of the strengths of the 3 cylinders.

b. The standard age of test specimens shall be 28 days; however, 7 day specimens may be fabricated and tested to facilitate concrete control.

c. The wet density and air content of all corcrete produced under the requirements of this specification shall be determined in accordance with paragraph $9 . d$. above. 


\section{DIVISION IV}

STRUCTURAI STEEL AND MISCEIIAANEOUS METAI ITEMS

CENERAI:

1. $30 \mathrm{OEE}$

Wis: 2 division of the specification covers all structural steel framing Exh miscelisneous metal items for the Fuels Recycle Pilot Plant, Building 3 i. Other miscellaneous meta? items are covered by Hanford standards Defexensea on the dratrings.

2. GTEMTSSION OF DRAWLNGS

The cosiractor shall submit complete shop drawings, exection diagrams and bia. of material for all structural steel framing to the Commission for arrovac in accordance with the requirements stated in the Special Gualtiors. Field connections shali be designed for bolting except

- wese weids are specifically show on the layout drawings.

3. $\mathrm{AFERREITHED} \mathrm{SMANDARDS} \mathrm{AND} \mathrm{SPECIFTCATTONS}$

gree stisndards and specifications listed below form a part of this sferification to the extent indicated by subsequent references.

3.2 ANERTCAN INSTITUTE OF STEEL CONSTRUCTION (AISC)

Sixerifiegtion for the Design, Fabrication and Erection of Structural g.tesi for Builaings, 1949 .

RSS 21-60 Specifications for Structural Joints Using ASTM A325 BoIts

\subsection{AMEPICAN SOCIEIY FOR TESTING AND MATERIAIS (ASTM)}

ABTM $A T-6 I T$

As3 $A 36-61 \mathrm{~m}$

$8 \sin \mathrm{A}-94-59 \pi$

$58 M$ B $245-619$

$A 95, A 276060 T$

4.: $A 283-58$

S.SM A 307-61T

SSTM $1300-592$ \&.S.M $325-61.5$
Steel for Bridges and Buildings

Structural Steel

Carbon and Alloy Steel Nuts for Bolts for High-Pressure and High-Temperature Service

Flat-Rolled Carbon steel Sheets of structural quality

Hot-Rolled and Cold-Finished Corrosion-Resisting Steel Bars

Low and Intermediate Tensile Strength Carbon Steel Plates of Structural quality

Low Carbon Steel Externally and Internally Threaded Standard Fasteners

Alloy-Steel BoIting Materials for Low-Temperature Service High-Strength Stee? Bolts for Structural Steel Joints, Including Suitabie Nuts \& Plain Hardened Washers 


\subsection{BNTETMAN SOSIETI FOR TESTING AND MATERIALS (ASTM) (Continued)}

ESTM R308-63 Aluminum-Alloy Standard Structural Shapes, Rolled or Extruded

\subsection{FELERA SPESIFICATIONS}

TNoF-86ai Paint, Red Lead, Ready-Mixed

5is

3.4 MNYTED SIATES MARITDME ADMINISTRATION

5i: Mis 202 Paint, Primer, Zinc-Chromate

3.5 SEAEL JOIST INSTMITUEE

Speciffication for Iong Span Steel Joists

3.6 FRNOORD STANDARD SPECIFICATIONS

gWTS $806-s$, Rev. 5 Austenitic Stainless Steel Plate, Sheet and Strip HWE 806 HoS, Rev. 5 Seamless and Welded Austenitic Stainless Steel Fipe

\section{MATERIALS}

4. CRFBON STEEI PTATES, SHAPES AND BARS

S. Fodied structural steel plates, shapes and bars for building framing and mis:ellaneous supports shall conform to the requirements of ASTM A7 or ESTM A36. At certain locations shown on the drawings the members used shail meet the requirements of ASIM A36.

b. Steei floor plates, including checkered plate, shall conform to the rexuzirements of ASTM A7 Or ASTM A283.

5. OZTIVIVE STEEI JOTSTS

ruermeb stieel joists, as shown on drawing H-3-20220, shall be parallel chord, underslung type conforming in all respects to the specifications of the siteel joist Institute for longspan steel joists.

6. TUSS POR ASSEMBLIY AND ERECTION OF STRUTTURAL STEEEL

501ts, nuts and washers for all permanent connections in structural steel. colum, besm and truss connections shall conform to the requirements of 
6. EN.TS FOR ASSEMBLY AND RRECTION OF STRUCTURAL STEEL (Continued)

A 3 M s.355. Bolts and nuts shall be heavy hex series. Bolts and nuts for Furi:- and girt connections and for other miscellaneous connections such Es stars, handrails, etc., shall conform to the requirements of ASIM A 307 , Gide A

7. BESP SOET PATIN FOR STRUCTURAL STEEL

Po:in for shop priming structural steel framing members, and prefabricated assenhifes such as curb angles, open-web joists, pipe sleeves, etc. shall be a prodrot conforming to the requirements of one of the specifications listed be ar $_{\text {, }}$ except where special protective coatings will be required (see oosine schedule in Division XVI):

a. FedereI Specification TI-F-86a, Typs II or III (red lead).

b. USMA: $5 \tilde{E}$ MA 202 (zinc chromate).

8. GREDIDI STAIR TREADS AND NOSINGS

8.1 GWNTART FLOOR GRATING AND STAIR TREADS

9. Steei grating and stair treads shall be welded or pressure locked type conforming to Federal Specification RR $G_{-6} 661 a$, Type I. Riveted grating will not be acceptable. Bearing bars shall be $1^{\prime \prime} \times 1 / 8^{\prime \prime}$ minimum.

b. Stair treads shall have an abrasive nosing with aluminum oxide or carbomudum grit impregnated into the surface of the metal. Treads shall be jesigned to fasten to staix stringers by bolting.

c. Grating shall be galvanized after fabrication except grating for Chemical Makeup platform and Iruck Lock simp may be black. Banding bars shall be used on perimeter of sections. Openings in grating, more than 4 inches in diameter, shall be banded. Grating shall be furnished with wedge type clips for fastening grating to the flarges of supporting structural framing.

\subsection{SFESIAI GRATINGS}

Iriting to be installed over the Cold Canyon Tank Pit shall be 5 inch I-beam: ven trye, bridgewloor grating. I-beam sections shall be on 6 inch centers end stail be parallel to the direction of traffic. The grating shall have $\pm / 4$ inoh thick checkered plate welded to the upper face as shown on the arswags. Reliance Steel. Products Co. 5 inch "Weldlock" open style Bridge Fivoring Iype P, and U.S. Steel Co. 5 inch "I-Beam-Iok" Open Floor Type Pu, Exe eximpies of gratings meeting the requirements stated herein. 


\subsection{AMTINIM GRATINGS AND FRAMING}

. Aluminum grating shall have $1 " \times 1 / 8 "$ main bars, except where specified otherwise on the drawings, and shall be standard rectangular mesh letterm. Grating shall be Rockwell-Standard Corp. "Gary" grating type GAlojoOA2, or approved equal.

b. Aluminum framing for grating over Wet Basin shall conform to the requirements of ASTM B308.

9. IEAD ERICKS

Sh:Ëling bricks for shielding around Samplers (EPN 113 and 114) and at ends of tank recess (EFN $177 \mathrm{TR}$ ) shall be $2^{\prime \prime} \times 4^{\prime \prime} \times 8^{\prime \prime}$ and shall be cest. of rig Iegd. Bricks shall be squared, suitable for stacking.

\section{BTISEATE LOUVERS}

Iovers for the sunshade canopy adjacent to the bullding entry shall be minimum i2 B\&S gauge Type 6063-T5 aluminum alloy. Blades shall have 2 reiaforeing ribs and returns along the Iongitudinal edges. Louver sections shis il be fabricated in a box channel frame to fit the structural steel surports shown on the drawings. Louvers shall be Extruded Louver Corp. Eyebron Type Solar Canopy, with Style I fascia frame, or approved equal.

\section{IENTIEATON INTAKE LOUVERS}

Ventiation intake louvers shall be 16 gauge galvanized steel blades in 4" ceep 16 gauge gelvanized steel box channel frame. Blades shall have retuxrs formed at edges for stiffness. Bird screen shall not be irstailed. Inuvers shall be shop coated with zinc chromate primer of the rype speoiried in this division. Louvers shall be sized to fit the steel fruming shown on drawing $\mathrm{H}-3-20223$. Louvers shall be American Warming \& Feritilaing Co. Type LW-P-170, with Type "A" frame and Type "J" blade and whout bird screen, or approved equal.

\section{AIIMIUMM JANDRAII}

c. Aiminum hendrail for stairway No. I shall be Blumcraft of Pittsburgh, assembied from the following parts, or an approved equal:

(1) Rail, 3" wide, style 112 , offset $21 / 2^{\prime \prime}$ center of rail to center of post.

(2) Post, 38" high, SP-II, 1 I/2" diameter, $4^{8}$ spacing, with $31 / \mathrm{C}^{\prime \prime}$ gooseneck extension. 
a. (Continued)

(3) Wall bracket - standard, WB-4, $31 / 4 "$ center of rail to wall.

(4) Fiat lateral (return) double $90^{\circ}$ bend.

b. Aluminum handrail assembly shall be formed from Type 6063 alloy and shaII be satin finish coated with clear, methacrylate lacquer.

13. STAINTEESS STEELS

a. Stuinless steel plate, sheet and strip shall conform to the requirements of Fanford Standard Specification HWS-806i-S.

b. Stainiess steel pipe for miscellaneous uses other than piping systems singl be seamless or welded conforming to the requirements of Hanford Standard Specification HWS-8064-S.

c. Stininiess steel bars and shapes shall conform to the requirements of fSTM A276.

d. Stainiess steel bolting materials shall conform to the requirements of ASTM A320, Grade B-8. Nuts shall conform to the requirements of ASTM A1.94, Grade 6 (Type 416).

WORKMANSHIP

14. FABRTCATION AND ERECTION OF STRUCTURAI STEEL

a. Fisorication and erection of stmuctural steel framing shall be in strict. conformance with the AISC Specification for the Design, Fabrication and Errection of Structural Steel for Buildings, except as noted otherwise herein or on the drawings.

b. Bcited connections shall be made in accordance with the requirements of AISC 211-60. Nuts shall be tightened by the use of torque wrenches or by the "turn of the nut" method.

(1) If torque wrenches are used, nuts shall be tightened until the indicator reads as follows for the various sizes of bolts:

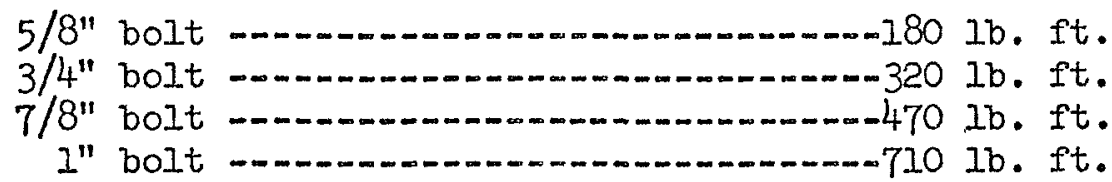


14. FABETCATION AND ERECTION OF STRUCTURAL STEEI

b. (Continued)

(2) If torque wrenches are used they shall be calibrated once on each work shift using instruments supplied by the Commission.

(3) If the "turn of the nut" method is used, nuts shall be "free ruming" and the several parte of the joint shall be properly compacted by bringing at least onemhalf of the bolts to a snug tight condition, such as can be produced by a few blows of an impact wrench or by an orjinary spud wrench. Final tightening of the nuts shall consist of marking the position of the nut and giving it a 1/2 turn from the snug tight cosition, progressing from the most rigid part of the joint towsio the free edges.

15. SEOP EATNRTNC OF STRUCTURAI STEEI

s. Ali structural steel shall be given a shop coat of paint in the sabricator's shop using one of the types of paint specified in Setuion 7 above, except that steel to receive special protective sotinge shall be shop primed with the matelas il iisted in the couting schedule shown in Division XVI.

b. Structural steel shall be cleaned prior to receiving shop coat paint. oid and grease shall be removed by solvent cleaning. Weld spatter shaic be removed by chipping and grinding. Rust and loose mill scale shall be removed by wire brushing.

c. The shop coat of paint shall not be applied when the steel is damp or then the steel or the ambient temperature is below $40 \mathrm{~F}$.

16. IECONTMMTISTON STALI

8. Caxbon steel plates and shapes shall conform to ASTM A36.

b. Csmbon steel sheets shall conform to ASTM A245.

c. Stainans steels shali be type 304 I conforming to the requirements $s^{4}$ sted in Section 13 above.

d. Weiding shsII conform to the requirements stated in Division V. Weiding of carion steel parts shall be done by the shielded metal Exc process.

e. Carbon steel parts shall be finished with special protective coatings s. sxecticed in Division XVI. 
17. SAMPIER HOODS - EPN 324-2500-113S \& 114S

a. Stainless steel sampler trench liners, hoods, and parts shall be fomed from type $304 \mathrm{~L}$ steel as specified in Section 13 above.

Finish of plate and sheet shall be $2 B$.

b. Welding on samplers shall be done in accordance with the requirements stated in Division V. Welding process used shall be inertgas-shielded tungsten-arc with 308L filler metal. Radiography, sectioning and/or trepanning of welds will not be required.

c. Burrs and weld spatter shall be removed and all welds ground to a No. 63 finish. All scratches and gouges shall be smoothed by wire brushing and grinding. Only stainless tools shall be used to finish stainless steel. Grinding wheel shall be 120 grit.

d. Except where shown otherwise on the drawings tolerances for linear dimensions shall be as follows:

$$
\begin{aligned}
& \text { O" - 12" - plus or minus } 1 / 32 \text { inch } \\
& \text { over 12" - plus or minus } 1 / 16 \text { inch }
\end{aligned}
$$

18. INSTAIIATION OF STAINLESS STEEL LINERS

a. Stainless steel liners in the process cells, the sampler trenches in Room 145 and the pipe trench in Room 135 shall be Type 304L stainless steel. Splash shield in the Cold Canyon shall be Type 321 stainless steel. Stainless steel liners in tank vaults, pan under head tanks cn roof, floor pan in the Chemical Makeup Room and the sump in Room 4 shall be Type 304 stainless steel.

b. Where stainless steel liners are to be anchored to carbon steel, such as in process cells, the concrete of walls and floors shall be ground flush with the steel anchor shapes and the steel cleaned of mortar and dirt to provide uniform bearing for the liner sheets. Ground surfaces shall extend a minimum of $6^{\prime \prime}$ back from the anchor steel where necessary to remove abrupt irregularities in the concrete. These requirements are in addition to those stated in Division II, Section 12.

c. The stainless linex sheets shall be butted together and anchored with screws as shown on the drawings. All butt joints between liner sheets shall fit within $1 / 16$ inch. If sheets do not fit within the tolerance epecified, the edges of sheets shall be ground off until proper fitup is attained.

d. Liner sheets shall be seal welded with the inert-gas-shielded-tungstenare process without the addition of filler metal. It is important that liner welds, which are backed up with carbon steel, are not $100 \%$ penetration welds which could cause fusion with the carbon steel. Anchor screws shall be set flush with, or very slightly above, the 


\section{INSTALTA TTON OF STAINLESS STEEL LINERS}

a. (continued)

surface of liner sheets and fused with the liner the same as the seams. Hozes drilled in liner sheets for anchor screws shall not have burrs removed.

e. Wherever the surface of a seal weld in liner sheet is $1 / 64$ inch or mose below the surface of the liner an additional weld pass shall be made adding filler metal to bring the surface of the weld within the tolerance specified. Any projection of the weld above the surfece of the surrounding liner sheet shall be ground off flush using \& 120 grit wheel to finish off the weld.

f. Hegt stain shall be removed from all liner welds using a stainless steel wire brush. 


\section{DIVISION $\mathrm{V}$}

WEIDING

GENERAL

1. $\operatorname{scos}$

Titze division covers all welding in connection with the construction of the Fuels Recycle Pilot Plant, Building 324.

2. FEYTEENGED STANDARDS AND SPECTFICATTONS

mie stindards and specifications listed below form a part of this specification io the extent indicated by subsequent references.

2.1 AMERIGAN STANDARDS ASSOCIATION (ASA)

ASA B3I.1-1955 - Code for Pressure Piping

2.2 ABERTCAN WEIDING SOCIETY (AWS)

A.jE E3.O - Standard Qualification Procedure

\subsection{IIANFORD STANDARD SPECIFICATIONS}

FW.

Mh-4903-S, Rev。 4 - Welding Aluminum and Aluminum Alloys

THW $-4924-5$, Rev. 6 - Welding Stainless Steels

Hivit926-S, Rev. 5 - Welding Carbon steels

2.4 AMERTCEN SOCIETY FOR TESTING AND MATERTAIS

ASTM A37I-53T, Corrosion-Resisting Chromium and Chromium-Nickel steel Welding Rods and Bare Electrodes

3. QTAIUTICATION OF WEIDERS

AII Fersons who perform welding covered by these specifications shall be gidified in accordance with the requirements specified below:

¿. Welds on structural steel building framing shall be made only by relders who have been previously qualified by tests as prescribed in AWS B3.0. 
b. Weids on pressure piping shall be made only by welders who have been prey:ously qualified by tests as prescribed in section 6, Chapter 4 of ASA B3I.I.

c. Weids on aluminum and aluminum ailoys shall be made only by welders who have been qualified by tests in accordance with the requirements of Hanford Stanaard Specification HW-4900-S.

d. Weids on stainless steel, other than pressure piping, shall be made only by welders who have been qualified in accordance with Hanford Standard Specification HW-4900 $\mathrm{S}$.

e. It shall be the responsibility of the contractor to insure that welders in his employ have been properly qualified as specified above prior to performing welding which will become a part of the work covered by these specifications. The results of the individual welder performance gualification tests shall be made available to the Commission......

\section{WEIDTN PROCEDURES}

2. Commission-approved and qualified procedures governing the welding Epecified hexein are on file in the office of the Commission. Copies of these procedures will be made available for use by the Contractor un request.

b. If the Contractor elects to use his own procedures, qualification test results of such procedures shall be presented for approval by the cormission prior to welding on any items which will become $a$ bert of the work covered by these specifications. Procedures rresented to the Comission for approval shall be in the form as recommended in Appendix A to section 6 , of ASA B3I. 1 .

\section{MATERIALS}

5. EIIIEF METAI

a. Fin metal used in welding carbon steels shall conform to the requirements stated in Hanford Standard Specification HW-4926-S.

b. ralier metal used in welding aluminum and aluminum alloys shall cunform to the requirements stated in Hanford standard Specification ghy $01903-5$. 
5. TIIIER METAL (Continued)

c. Filler metal used in welding stainless steels shall conform to the requirements of ASTM A371. Type 308 filler metal shall be used to join Type 304 stainless steel to Type 304 or Type 316 stainless stieeis. Type 308L stainless steel filler metal shall be used to join Trye 304I to Type 304I, Type 321 or Type 316I stainless steels. Tyce 308I filler metal shall also be used to join stainless steel to carbon steel.

6. WELD COATING

Coatirg meterial for weld areas on galvanized or other zinc-coated steel shali be All-state Galvanizing Powder No. 32l, or Allostate "Galvabar", as manufactured by the All-State Welding Alloy Co., White Plains, N. Io, or arproved equal.

\section{WORKMANSHIP}

7. FABRICATION OR PRESSURE PIPING

a. Welding of carbon steel and/or stainless steel piping shall be done in arcordance with the American Standard Code for Pressure Piping; ASA B31.1, Section 6, Chapter 4.

b. In addition to the above, welding on carbon steel piping shall meet the quality requirements specified in Hanford Standard Specification HW $4926 \mathrm{~m}$.

c. Welding of stainless steel piping shall also meet the quality requirements specified in Hanford Standard Specification HW-4924 SS. The inert-gas-shielded-tungsten-are process shall be used for welding stginless steel piping。

8. WEIDTVO CF CARBON STEET PIATE, SHEET, AND MISCELTANEOUS SHAPES

Heljing of all carbon steel plate, sheet, and miscellaneous structural shages other than pressure piping, building framing and pressure vessels siva 11 be done in accordance with the requirements of Hanford Standard Sfeeification HW-4926\%S。

9. WELDNVI OF STA INLESS STEET PIATE, SHEET, AND MISCELIANEOUS SHAPES

Welding of all stainless steel plate, sheet, and shapes shall be done in Eccordance with the requirements of Hanford Standard Specification HW $4924 \mathrm{mS}$. The ¿nert-gas-shielded-tungsten-arc process shall be used to weld-stainless : $:$ i sheets and shapes $3 / 16$ inches and less in thickness. 


\section{WEIDING OF AIUMINUM}

Welding of all aluminum and aluminum alloys shall be done in accordance with the requirements of Hanford Standard Specification HW-4903-S.

i1. COAMING OF WELDS ON GALVANIZED SUREACES

Where welding of galvanized steel is done, the weld area shall be cleaned of weld spatter and oxides and the entire area coated with a gelvanizing coating of the type specified in section 6 above. The moterial shall be applied to provide a protective coating over the entire area effected by the welding operation. 
DIVISION VI

PIPING AND PLUMBING

GENERAI

1. SSORE

Wris division covers piping and plumbing, including sanitary and washroom fixtures for the Fuels Recycle Pilot Plant, Building 324. Iunchroom and isboratory cabinet sinks are specified sn Division XXII.

2. REYF:FENCED STANDARDS AND SPECIFICATIONS

The specifications and standards iizted below form a part of this specifisation to the extent indicated by subsequent references.

2.1 AMERICAN SOCIETY FOR TESTING AND MATERIAISS (ASTM)

ASTM A53-6IT

ASTM AT2-59T

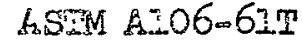

ASTM A $120-61$ I

ASTM A293-6IT

ASTM A.3. 4 - 59 T

ASTM ACI6-60T

ASTM A296.60m

ASTM $A 307-612$

A.s.M. $25:-60$

Asin $862-60$

$89 \pi \mathrm{m}=75 \mathrm{~m}=$

ASTM $\triangle 278.61 \mathrm{~m}$

ASTH CHE5-60T

ASTM $A 312.61 T$

ASTM $\& 403-61 T$
Specifications for Welded and Seamless steel Pipe

Specifications for Welded Wrought-Iron Pipe

Specifications for Seamless Carbon-Steel Pipe for High

Temperature Service

Specifications for Black and Hot-Dipfed Zinc-Coated

(Galvanized) Welded and Seamless Steel Pipe for Ordinary Uses Specifications for Alloy-Steel Bolting Materials for Higho Temperature Service

Specifications for Carbon and Alloy steel Nuts for Bolts

for High-Pressure and High-Temperature Service

Specification for Carbon Steel Castings Sujtable for Fucion Welding

Specification for Corrosion-Resistant Iron-Chromium and Iron Chromiun-Nickel Alloy Castings

Specification for Iow-Carbon Steel Externally and Internally

Threaded Standard Fasterers

Stesm or Valve Bronze Castings

Composition Bronze or Ounce Metal Castings

Seamless Copper Tube

Specifications for Extre Strength Unglazed Clay Pipe

Specification for Vitrified Clay Pipe Joints Using Materials

Having Resilient Properties

Seamless and Welded Austenitic Stainless Steel Pipe

Factory-Made Wrought Austenitic Steel Welding Fittings

2.2 WATIONAT FIRE PROTECIION ASSOCIATION (IIPA)

IHFA 58-1961, Iiquefied Petroleum Gases. 


\subsection{MNEF TSM STANDARDS ASSOCIATION (ASA) CODES AND STANDARDS}

Es St Specifications for Cast Iron Pipe Centrifugally Cast in

ACA A2 80.953

Metal Molds, for Water or other Iiquids

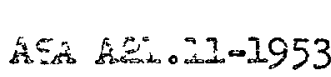

Srecificatione for Csst Iron Pipe Centrifugally Cast in

Sand-Lined Molds, for Water or Other Iiquids

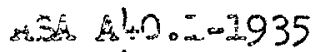

SFecifications for Mechanical Joint for Cast Iron Pressure

Pipe and Fittings

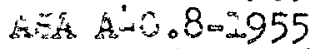

Cast-Iron Soil Fipe and Fittings

National Plumbing code

sis $5= \pm 0=960$

Polysulphide - Ease Sealing Compounde for the Building Trate

Es.s. 5.5 .301951

A $3=0.60402949$

Maileable-Iron scretred Fittings, 150 Ib

A. $52.50 .50=961$

fis $20.00=958$

Esca $3.6 .11-2946$

E. $=5.5 .520 .2953$

B. $=$. 3.1901951

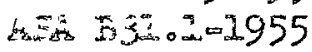

Cast-Iron Screwed Fittings, 225 and 250 Ib

Steel Pipe Fianges end Fianged Fittings

Steel Buttoweiding Fittings

Steel SocketcWeiding Fottings

Casi-Iron Screwed Drainage Fittings

Maileablewiron screwed Fittings, Class 300

Code for Pressure Fiping

2.4 BNIROGAN WATER WORKS ASSOCIATION (AWWA) STANDARD

ESTW CEO3-5?

Standard for Coal-Tar Enkmel Protective Coatings for Steel Water Pipe

2.5 TEDEFI SPECIFICATIONS

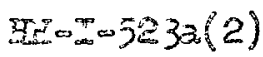
Insulation: Block, Fife Covering, and Cement, Thermal,
$7 x-\infty=5 i 0(2)$ Calcium silicate
$\mathrm{FP}-\infty=562$
Insulation: Thermsi. Asbestos, Block and Pipe Covering

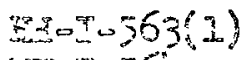 Insulation: Trerme; Mineral Wosi, Block or Board and Fift Insulation
$10+\infty, 5$
Insulation: Mineral Wosi, Barket, Felt and Industrial Bst.

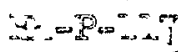
Insulation: Minerai, W20?, BLock and Board
$Q 0+1-56(1)$
Packing; Jute, Fististed
$7-50=70$
Lead; Caiking

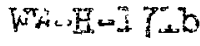
Paper: Buizding, Waterkrosfed
Hangers and Supports: Fife
2.6 STES BUREAU OF STANDARDS
$-2=-45 \quad$ Drinking Fountains

2.7 I

M.5 Rev O Fiange and Valve Bonnet Guaxds

ive Rev O Fure Hydrant 


\subsection{TANTCFD STANDARDS (Continued)}

RTi $-4924-5$ HW $-49060 \mathrm{~S}$ $\mathrm{EWW}-4966 \mathrm{~m}$

शTS $8064-5$

HWS-8066 $\mathrm{cos}$

HUS- $8067 \cdot 5$
Rev 6 Specification for Welaing Strinless steels

Rev 5 Specification for Welding Carbon Steels

Rev 1 Specification for Disinfecting Sanitary Water Supply Systems

Rev 5 Specification for Seamless and Welded Austenitic Stainless steel Pipe

Rev 4 Specification for Factory-Made Wrought Austenitic Stainiess Steel Welding Fittings and Flinges

Rev 4 Specification for Stainless steel Welding Electrodes and. Fiiler Materials

2.8 AMEROSEN SOCIEMW OF MECHANICAL ENGTNEERS (ASME)

Boilex Couie IOE? Section VIII, Code for Unfired Pressure Vessels

\section{MATERIAIS}

\section{PIPE AND FITIINCS}

Q. Except for the substitution allowed by Section $3 b$ below, pipe and fittings shall be as specified in the Piping codes of this specification and an s.eompenying drawings and specifications for the particular service.

b. For treided main lines $2^{\prime \prime}$ and iarger, branches smaller than the main may be maxe with Weldolets, Sockolets or Thredolets, Bonney Forge \& Tool Woriss, or approved equal, instead of the butt-welding tees specified in the Fiping codes of this specification. When this substitution is chozen, Weldolets shall be used for branch line specified to be buttw welzed, Sockolets for socket-welded, and Thredolets for threaded. Materias and weight shall correspond to that specified for the particular injing system.

o. Ciose or kutt nipples are not permitted.

a. Ail biack steel piping to be exrosed to earth backfill shall have an sxtersor protective coating of coal-tar enamel with bonded asbestios reit rsop in accordance with AWWA C203.

e. Poivethyiene tape for coating stainiess steel pipe exposed to earth backfili shall be not less than 20 mils ( 0.020 inches) in thickness (froiudirg adhesive). The tape and its adhesive shall not contain more than $6 \mathrm{ppm}$ of combined chlorire in any form. The tape shali be Polyken Division of the Kendall Co. "Polyken" No. 920, or approved equias.

f. In pixing code H-22, where Hanford Standard Specifications HWS-8064-S and 8066-3 are specified for procurement of stainless steel pipe and fittings, trs requirement for test coupon in section 6 of each of the referenced sreaffications shall be disregarded. 
4. VALVES

Vaires identified in the Piping Codes by code number are specified below. Brand names are shown only to illustrate the type and class of valve required. Valve packing shall be the manufacturer's standard for the service involved. Valves shall be as specified, or an approved equal.

4.1 UAIE VAITES

Code Number

$6.0 \leq 176$

Gi.2 F 302

a 1.25601

Q 1.5 S 628

G $2.0 \leq 652$

1.5 F 801

$6 \pm .2 \mathrm{M} 503$

\section{Specification}

600 Ib. forged steel, ISRS, with screwed ends, Crane Co. No. 3634XU

Pacific Valves Fig. No. 65-3A,

Hancock Valves No. $930-5$

I25 Ib. CI with bronze trim, OS\&Y; flanged.

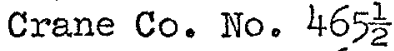

Walworth No. $726 \mathrm{~F}$,

Wm. Powell Co. Fig. No. 1793

I25 1b. bronze, screwed ends, replaceable disc, brass trim, ISRS

Crane Co. No. 440

Walworth Co. No. 3

Jenkins Bros. Fig. No. 62-U

$150 \mathrm{Ib}$. bronze, RS; screwed ends and bonnet. Crane Co. No. 431

Ohio Injector Co. No. 96

Iunkenheimer Co. Fig. No. 2151

200 1b. bronze, ISRS, screwed ends.

Walworth No. 37 ,

Wm. Powell Co. Fig. No. 375

Ohio Injector Co. No. 7200

150 1b. 18-8S stainless steel, OS\&Y, solid dise, f flg's. Pacific Valves Fig. No. G500

Wm. Powell Co. Fig. No. 2491 (CF-8)

Cooper Alloy Corp. No. I00SW (CF-8)

AWWA Class C, IBBM, NRS, mechanical joint ends. $M$ \& $\mathrm{H}$ Valves $\mathrm{Fig}$. No. $67 \mathrm{M}$, Eddy Valves No. F-2405 
4.I CAITE VAIVES (Continued)

Code Number

Specification

Q $1.2 \mathrm{M} 504$

G 6.0 T 276

Same as \#503 above except adapted for mounting indicator post

$M$ \& $\mathrm{H}$ Valves Fig. NNo. 82M,

Eddy Valves No. F-2405

$600 \mathrm{Ib}$. cast or forged steel, OS\&Y, socket weld ends, with stainless steel trim.

Pacific Valves Fig. No. 3652-3A

Reading, Pratt \& Cady Fig. No. F57K,

Crane Co. No. $3611 \mathrm{XU}$

4.2 GLOBE VALVES

Code Number

Specification

GL 2.2 F 304

GL 1.2 F 316

Cii $1.2 \leq 604$

125 Ib.C.I., IBBM, OS\&Y, bevel disc, flanged. Crane Co. No. 351

Walworth No. 906F,

Wm. Powell Co. Fig. No. 241

125 Ib. C.I., OS\&Y, bronze seat, comp. disc for $150 \mathrm{lb}$. Argon gas and $5^{11} \mathrm{H}_{2} \mathrm{O}$ vacuum service at $80 \mathrm{~F}$

Crane Co. No. 359

Walworth Co. No. $914 \mathrm{~F}$

Wm. Powell Co. Fig. No. 301

$125 \mathrm{lb}$. bronze, ISRS, brass disc, screwed ends. Walworth Co. No. 58,

Lunkenheimer Co. Fig. No. 2140

Reading, Pratt \& Cady Fig. No. Oll.

GL $1.5 \$ 626$

$150 \mathrm{lb}$. bronze, ISRS, comp. disc., screwed ends. Crane Co. No. 7,

Walworth Co. No. 95 ,

Wm. Powell Co. Fig. No. 150

c.s. 2 s 653

$200 \mathrm{lb}$. bronze, ISRS, union bonnet, stainless trim, screwed.

Crane Co. No. $212 \mathrm{P}$,

Walworth Co. No. 245 P,

Wm. Powell Co. Fig. No. 1708 
4.2 TIOBE VALVES (Continued)

Code Number

OI 2 S 659

aㅣ $1.5 \mathrm{~F} 804$

도 6.0 T $2 \pi 7$

A $1.2 F 320$

A $1.5 \mathrm{~S} 627$

A $2.0 \mathrm{~S} 655$

Code Number

A 1.2 F 305
Specification

200 Ib. bronze, ISRS, screwed ends, with special composition disc, Underwriters Laboratories approved for " $L P$ " gas.

Crane Co. No. 130,

Walworth Co. No. 91,

Wm. Powell Co. Fig. No. 8150

$150 \mathrm{Ib} ., 18-8 \mathrm{~s}$ stainless steel, 0S\&Y, plug disc, flanged.

Pacific Valves Fig. Ho. G700,

Wm. Powell Co. Fig. No. 2475 (CF8),

Cooper Alloy Corp. No. 10 (CF8)

$6001 \mathrm{~b}$. forged steel, OS\&Y, plug disc, socket weld ends. Pacific Valves Fig. No. 3662-3A

Crane Co. No. 3652W,

Ohio Injector Co. No. $1727 \mathrm{mCH}$

4.3 ANTTE VALVES

125 1b. C.I., bronze trim, OS\&Y, bevel disc, flanged ends. Crane Co. No. 353,

Walworth Co. No. $907 \mathrm{~F}$,

Wm. Powell Co. Fig. No. 243

125 Ib. C.I., bronze seat, composition disc, for 150 Ib. Argon gas \& 5" $\mathrm{H}_{2} \mathrm{O}$ vacuum at $80 \mathrm{~F}$.

Crane Co. No. 36I-

Walworth No. $915 \mathrm{~F}$

Wr. Powell Co. Fig. No. 308

150 Ib. bronze, ISRS, brass seat, composition disc, screwed ends.

Crane Co. No. I7,

Walworth Co. No. 96 ,

Wm. Powell Co. Fig. No. 151

200 lb. bronze, ISRS, stainless trim, screwed ends. Crane Co. No. 214.. $\mathrm{P}_{8}$

Walworth Co. No. 246-P,

Wm. Powell Co. Fig. No. 1709 
4.3 ANGLE VAIVES (Continued)

Code Number

A 1.5 F 811

A $2.0 \mathrm{~S} 661$

A 6.0 T 278
Specification

150 Ib. 18-8S stainless steeI, OS\&Y, plug disc, flanged. Alloy steel Frod. Co. No. 331 (CF8),

Wm. Powell Co. Fig. No. 2479 (CF8),

Cooper Alloy Corp. No. 50 (CF8)

200 Ib. bronze, ISRS, special composition disc, UL approved for "IF" gas.

Walworth Co. No. 92,

Wh. Powell Co. Fig. No. 8151,

Ohio Injector Co. No. 547

$600 \mathrm{Ib}$. forged steel, OS\&Y, stainless trim (F8), socket welding ends.

Crane Co. No. 3653W,

Ohio Injector Co. No. $2127-\mathrm{HCH}_{\text {, }}$

Hancock Valves No. 5530W

\section{Specification}

125 Ib. C.I., bolted cap, swing disc, bronze trim, flanged. Crane Co. No. 373,

Walworth Co. No. $928 \mathrm{~F}$,

Wm. Powell Co. Fig. No. 559

125 Ib. C.Io, bolted flanged cap, horizontal lift, bronze Seat, composition disc for $150 \mathrm{Ib}$. argon and $5^{\prime \prime} \mathrm{H}_{2} \mathrm{O}$ vacuum at $80 \mathrm{~F}$.

Wm. Powell Co. Fig. No. 312,

Ohio Injector Co. No. 132,

Jenkins Bros. Fig. No. 153

c. 2.0 S 656

C 2.0 S 657
200 Ib. bronze, screwed cap, bronze swing disc, screwed. Crane Co. No. 36, Walworth Co. No. 420

Wm. Powell Co. Fig. No. 560

200 Ib. bronze, screwed cap \& ends, horizontal lift, special composition disc, UL approved for "IP" gas. Crane Co. No. 132,

Wm. Powell Co. Fig. No. 8158,

Jenkins Bros. No. 507 
4.4 CHESK VAIVES (Continued)

Coje Number

02.0 s 658

c. 6.0 ? 279

0.5 F 808

\section{Specification}

200 Ib. bronze, spring loaded lift, screwed ends, special composition disc, UL approved for "IP" gas. Walworth Co. No. 88, Iunkenheimex Co. Fig. No. 403

Stockham Valves Fig. No. B-326

600 Ib. forged steel, stainless trim, bolted cap, socket welding ends. Pacific Valves Fig. No. 3682-I,

Crane Co. No. $3682 \mathrm{X}$, Ohio Injector.Co. No. 2327-C

150 Ib. stainiess steel, swing disc, bolted cap, flanged ends. Pacific Valves Fig. No. GI100, Alloy Steel Prod. No. 371, Cooper Alloy Corp. No. 2002

4.5 DIAPHKAGM VAIVES (Saunders patent)

Code Nimber

D 1.5 F 327

D 1.5 F 328

D 1.5 P 330

$D 1.5 S 441$

I. I.5 S 442

\section{Specification}

150 Ib. C.I., Hycar diaphragm, flanged ends, UL approved for "LP" gas at 50 psig. \& $80 \mathrm{~F}$.

Saunders No. IF-243I-IP

Same as above except neoprene diaphragm. For water and ethylene glycol at $150 \mathrm{Ib}$. and $50 \mathrm{~F}$. Saunders No. 243I-I-T

$150 \mathrm{lb}$. C.I., reinforced neoprene diaphragm, flangeã ends, for vacuum air sampling at $80 \mathrm{~F}$. Saunders No. 243I-I-TV

150 Ib. C.I., Hysar diaphragm, screwed ends, UL approved for "IP" gas at $50 \mathrm{psig}$ and $80 \mathrm{~F}$.

Saunders No. I,P-240I-1-P

150 1b. C.I., neoprene diaphragm, screwed ends, for $150 \mathrm{Ib}$. Argon and water.

Saunders No. 240I-I-T 
4.5 DIAPHRAGM VALVES (Saunders Patent) (Continued)

Cole Number

D $2.5 \mathrm{~S} 443$

D 1.5 F 832

D. 2.5 F 833

4.6 INDICATOR POST

Coje Number

IP $1.2 F 512$
Specification

150 Ib. C.I., reinforced neoprene diaphragm, screwed ends for vacuum air sampling at $80 \mathrm{~F}$.

$150 \mathrm{lb}$. stainless steel body, Teflon diaphragm, flanged ends, for vacuum service at $24 " \mathrm{Hg}$ and $80 \mathrm{~F}$.

$150 \mathrm{Ib}$. stainless steel, white chlorinated butyl diaphragm, screwed ends, for denineralized water at 100 psig, and up to $200 \mathrm{~F}$.

Saunders No. 2433-1-WB-I

\section{Specification}

ISRS, left hand opening, plate glass window with "open" and "shut" target, with wrench and locking bar.

M \& $\mathrm{H}$ Valves Fig. No. 83, Crane Co. No. 5iO,

Ohio Injector Co. No. 420

4.7 SAFETY AND RELIEF VALVES

Safety and relief valves shall be as specified on the construction drawings.

4.8 EATIS VAITES

Qote Number

Specification

$2-52020$

Body: Bronze per ASTM B61 or B62. Screwed ends, graphite or viton seats and seals for $125 \mathrm{Ib}$. steam service. Hills-McCanna "McCannaseal" with "Graphitar" seats.

No. S-I52-Br-G

Pacific Vaives Fig. No. 225-Br-E4

$\operatorname{Em} 2021$

Same as B-S 2020 except with Buna-N seats and seals. Pacific Valves Fig. No. 225-Br-E2 Hills-McCanna"M-Carneflo" F-152-Br-B Jamesbury "DoubIe-SeaI" No. DIIBB 
4.8 ERET VAIVES

Co Je Number

E. 504

E. $-\mathrm{F}^{5} 2[4]$

8.4. 2155

Bis 2341

4.9 TMRAPS

code rumber

$2.5 \$ 1500$

4.10 ETMAINRRS

Qde Nimber

S. 2. S 1001

\section{Specification}

Body: carbon steeI per ASTM A216, Grade WCB. Screwed ends with Bunan sests and seals.

Jamesbury "Doubie-seal" No。D22BB,

Hills-McCanna "McĆannafIo" F-152-CS-B,

Pacific Valves Fig. No. 225-GSmE?

Body: carbon steeI per ASIM A216, Grade WCB.

150 Ib. flanged enis with Buna-N seats and seals

for vacuum service.

Hills-MCCanna "MeCennaseal" No. S-I5I-CS-B

Jamesbury Corp. No. DHV 5OF22BB

Pacific Valves Fig. No. 400-CS-E2-V

Body: stainless steel, ASTM A296, Grade CF8M.

150 1b. flanged ends with Teflon seats \& seals.

Pacific Vaives F.․g. No. 400-S-P5-V,

Hills-MeCanna "McCannaseal" SI5IS6T,

Jamesbury Corp. No. DHVI50F36T

Body: Forged steel, i50 Ib.

Ends: Socket welding

Seats and seals: Teflon

Hills-McCanna "McCannaseal" S303CST

\section{Specification}

Inverted bucket type for steam CI or steel, brass \& stainless steel mechanism, 150 psig max. screwed ends.

Crane Co. No. 9810

V. D. Anderson Co. No. 118

Sarco Co. type BI to B5.

\section{Specification}

"Y" type, CI or steel, $125 \mathrm{Ib}$. screwed ends and cap O.C. Keckley Styie B

Crane Co. No. $988 \frac{1}{2}$

Yarway No. 801 
5. IE UYE FIRE EROTECTION \& CELI WASHDOWN VALVES

\subsection{PESBRESCM OFERATED VALVES}

Es: $1-1 / 2$ inch

"res: Single Fort, On Off

Frosid: size, flat face for tight shutoff

D.rustresm Pressure: Atmosphere

Es: 50 em Pressure: 80 psig water at $70^{\prime} \mathrm{F}$.

I_ Consestions: Screwed NPT

Fe, rivg: 150 psig

SAs carbon steel or bronze

3phroris: 3 to 15 psig air diaphragm

W. Lion: Valye normaliy closed and to be Iully open with 15 psig air loading.

Ax segrories: To be equipped with 3 -way, brass, pilot valve on topworks with cylinder port connected to diaphragm chamber. Valve to be rated at $120 \mathrm{~V}, 60 \mathrm{cy}, \mathrm{AC}$ and with $1 / 2$ or $1 / 4$ inch NPT pipe connections.

Eearesentative Type: Fisher Governor Reg. Co., No. 510, or approved equal.

Ays: (1) EPN 324-849

\subsection{THEDEROM OPERATED VALVES}

Eิtre as 5.1 above except:

Soge zach

Ea Conjections: 150 1b. ASA flanged

As: (a) EPN $324-848$

(2) EPN $324-852$

(1) EEIN $324-853$

i.) EPN 324.854

(1) EPN 324-855

\subsection{OFERATED VALVES}

Bume \&.8 5.1 above except:

Size: 3 inch

E*I sanections: 150 Ib. ASA flanged

Ma: $=$ : (i) EFN $324-846$

(1) EPN $324-847$

(1) EFN $324-851$

6.

6.I D.SFIPA OFERATED VALVE FOR STEAM CONTROL

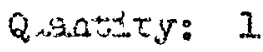




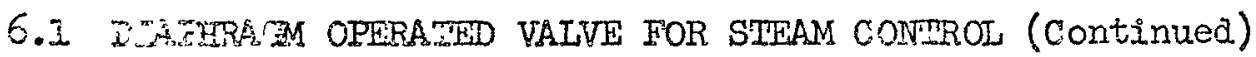

Size: I. I/ $\mathrm{sinch}$

Tire: Cobe, Single Seated, on-off, normelly closed (airuto-open), $5301 \mathrm{~b}$. ACA

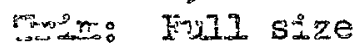

6ramestimons: Screwed

Materion: Manufacturer's Standard for the service stated

Esis: Saturated steam

Fivosm Fressure: 30 psig

Suescure Drop: 25 psi

1.07\%: I250 Ibs. Fer hour

Nororis: Offom with 3 to 15 psig gir

MAsmiz: ERN - . . 324 - $830 \mathrm{SV}$

6.2 DFAFAEA OFM OFRATED VALVE FOR COOLING WEATTER CONTROT

Q

Sus: I Inch

Ty: : : Move, singie seated, On-Off, normaily closed (air-to-open)

Fisin: Fuld size

Cotrections: Screwed

Metexig:: Manufacturer's standard for the service stated

Fors: Sanitary watex

Stopse Esesure: $80 \mathrm{psig}$

zensers Dror: 30 psi

Fus: 40 SEM

Wer wriks: OPfoon with 3 to 15 psig air

MEx: ESN o o . $324-830 \mathrm{WV}$

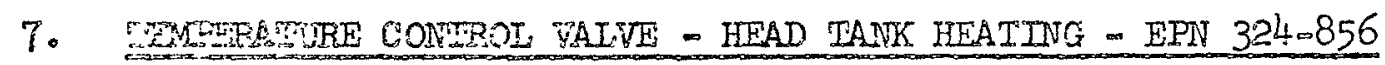

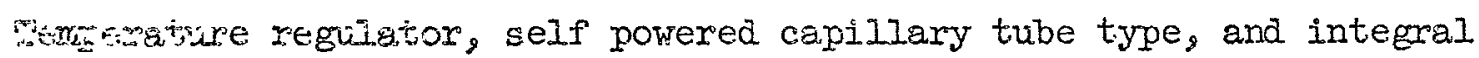
rivermometex。

Sumpe: Steam 15 psig

"Flire size: I/4" single seated

Wre: Direct acting (closes with rise in temp. at buib)

"L corvections: 1/2" IPS union connections

Qfis 2tiy: 20 frounds fer hour 15 fsig steam

Emf $=0$ tire buib: Standard liquid buib with $101 / 2^{\text {I }}$ IPS connection and 304 stainless steel protective thermowell with $1-1 / 2^{\prime \prime}$ male pipe thread.

Efgi ator Iempersture Range: $50 \mathrm{~F}$ to $105 \mathrm{~F}$ set at $80 \mathrm{~F}$.

revoneter Iemperature Range: (-) $10 \mathrm{~F}$ to $120 \mathrm{~F}$.

cosisisiny Length: 15 feet 
7. TEMPEFR TIEE CONIROL VAIYE - HEAD TANK HEATING - EPN 324-856 (Continued)

Representative Type: Robertshaw-Fulton Controls Company

No. 1003-EI with No. $12 \times \mathrm{B}$ bulb and

Marik: (2) EPN 324m856

Type G stainless steel thermowell.

8. STEAM FRESSURE REDLCING VALVE EPN 840 (DRAWING H-3-20486)

a. This vaive shall be a single seated, balanced metal diaphragm, normally cosed, packless, pilot operated, flarged valve.

b. Trisve shall be sized to reduce saturated steam from 120 psig to 15 psig sit meximum rate of 8,000 lbs per hour, and a minimum of 0 as required by hesting coils.

c. Fody material shall be cast iron with 125 Ib. ASA flanges. Pilot shall se cast iron with screwed connections. Fressure gauge for above service with biock valve shall be included.

a. Eegulator shall be Spence Engineering Co. Type ED, to meet the above rezuirements, or an approved equal.

9. JET CONLROL STATIONS (QUANTITY 2) (DRAWING H-3-20491)

9.1 JEI CONIROL SWITCH

a. Mrpoposition control (valvemoperating program switch) with time cycle to rrovide valve action as stated under SWIICH ACIION. When the two position switish is moved manually from oN to OFF position, the following events Isistis oscur automatically:

Switch Action (Aix Operated Valves)

Syiteh Position (Manual)

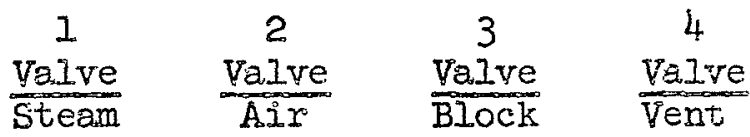

$\mathrm{CN}$

OFE (Immediate Action)

UE (Astion delayed 10-90 Sec.)

Open closed Open ciosed

Closed Open Open closed

Closed closed closed oxen

v. Trie only manual positions on front panel face shall be "ON" and "OFF"

c. Tine time delay shall be accomplished automaticaliy by pneumstic bleed rate ajustment to give the required time delay for valves 2,3 and i. Aftex the specified time delay, valves 2,3 and 4 shall be automatically oferated to put them in the position shown above as "OFF (10.90 seconds 


\subsection{TET CONRROL SWITCH}

c. (Continued)

later"). The valves shall maintain this position until the switch is minuiliy moved from "OFF" to "ON" position again.

Mounting: Sub panel assembly to be flush panel mounting.

Size: Approximately 4" x 8" panel front.

Finish: Manufacturer"s standard, smooth dull black.

service: Clean, dry air.

Supply Pressure: 20 psig.

Material: Manufacturer's standard

Pipe Connections: 1/4" NFT

Shut off Requirements: Must be satisfactory for dead end or continuous

bleed service.

Switch Position: Two (2) position - "OFF" and "ON"

Pressure Gauge: Sub panel shall contain one $21 / 2$ inch dial gauge, range 0 to 160 psig with $1 / 4$ " NPT back connection.

Ascessories: A key lock with two keys shall be provided in the handle. Fepresentative Type: Panellit. Ine., Skokie, Illinois

Maris:

Model 662-218, Standard Jet Switch Control

(1) EPN $324-115 \mathrm{JC}$

\subsection{JET HANC VATVES (DRAWING H-3-20491)}

a. Valve, Diaphragm Operated

Quantity: 2

Jyre: Single port globe, on-off, air-to-open.

size: $1 / 4$ inch body

Irim: i/8 inch diameter

Connertions: 1/4 inch screwed NPT:

tostream Pressure: 100 psig

Fivid: Compressed Air

Dorristream Pressure: Normaliy 0 psig. Valve must stand 90 psig saturated steam on downstream side.

Material: Manufacturer's Standard for the service temperature and pressure.

roporks: 0 to 20 psig air.

Lis: $=2 \mathrm{is}$ (1) EFN $324=115 \mathrm{G}-\mathrm{A}$

(i) EPI $324-116 \mathrm{G} \propto \mathrm{A}$

b. valves, Diaphragm Operated

Quantioty: 4

Type: Single Port globe, on off, air-to-open.

Si.ze: 1 inch body 
9.2 JEI GANG VALVES (DRAWING H-3-20491)

b. (Continued)

Troim: Full port size.

Connections: 1 inch screwed NPT.

Upstream Pressure: 125 psig.

Fiuid: Saturated steam

Downstream Pressure

No Flow - 0 psig

Full Flow - Less than I/2 upstream pressure

Material: Manufacturer's standard for the service temperature and pressure.

Topworks: 0 to 20 psig air.

Mark: I - : ENT. $324-115 \mathrm{G}=\mathrm{S}$

1 - EPN $324-116 \mathrm{G}-\mathrm{S}$

1 - :EN: $324-115 G-B$

1 - $324-116 G-B$

c. Valves, Diaphragm Operated.

Quantity: 2

Type: Single Port, Onmoff, air-to-close.

Size: $1 / 2$ inch body

Trim: Full part size

Connections: $1 / 2$ inch screwed NPT

Upstream Pressure: 125 psig

FIuid: Saturated steam

Dowristream Pressure: Atmosphere

Histerial: Manufacturer's standard for service temperature and pressure.

Topworks: 0 to 20 psig air.

Mark: 1 - :EFN. 324 - 115G-V

$1-:$ TPN. $324-116 \mathrm{G}-\mathrm{V}$

10. INSTRUMEIVT AIR - PRV - EPN 839

The FRV shall be a spring controlled pressure reducing valve to meet the following specifications:

Fuid

Fressure at inlet

Pressure at outlet

Temperature

Plow

End Connections

Eody Size

Fody Pattern

Trim
Air
100 psig
40 psig
$80 \mathrm{~F}$
25 SCFM
Screwed
I"
Double ported globe
Stainless steel 
I0. INSTRUMENI AIR - PRV - EPN 839 (Continued)

Shali be Fisher Governor Type 655GG to meet the above requirements or approved equal.

11. TENTIIATION INSTRUMENT AIR - PRV - EPN 839-A

The pressure reducing valve for ventilation instrument air (VIA) service shal: be the same as in Section 10 above except the body isize shal: be $3 / 4$ inch.

12. JOTNTITVG MATERIALS

a. joint sealant for all threaded joints shall be Teflon tape type, Scotch Brand Pipe Sealant Tape No. 547, Chemtrol Dri-Seal No. 5, John Crane "Thred-Tape", or approved equal.

b. Packing for cast iron hub-and-spigot sanitary sewer piping shall be twisted, impregnated jute conforming to Federal Specification $\mathrm{HH}-\mathrm{P}-1 \mathrm{I}$, Iype II.

c. Iead for caulking hub-and-spigot joints in cast iron sanitary sewer piping shall conform to Federal specification QQ-I-I56, Type I.

13. WETDIIUG ELECTRODES AND FIIIER METAI

a. Stainless steel welding electrodes and filler metal shall conform to Fanford Standard Specification HWS-8067-S. Type 308 or 308I shall be used for joining Type 304 piping and Type 308L for joining Type $304 \mathrm{I}$ piping and for joining Type 304I to carbon steel. Type 309 electrodes shall be used for joining Type 304 to carbon steel. Requirements for test coupons in HWS-8067-S, section 6 shall be disregarded.

b. Carbor steel welding electrodes and filler metal shall conform to Hanford Standard Specification HW-4926-S.

14. HANGESE AND SUPPORTS

a. Pipe hangers specified below are intended to show general requirements for support at locations where special supports are not detailed on the drawings. Perforated straps shall not be used for supporting piping.

b. Hangers for piping as specified below shall conform to the requirements of Federal specification WW-H-ITIb.

(1) Bare Piping $4^{\text {Piping }}$ \& smaller, and insulated piping $1 \frac{1}{4} "$ \& smaller
Hanger Type Type 18 Adjustable Swivel Nut Hanger 
14. HANGERS AND SUPPORMS (ii $1, i, \cdots .$. )

b. (Continued)
Piping
(2) Bare piping over 4"
(3) Insulated piping $1 \frac{1}{2}$ " and larger
(4) Clamps for suspending from the bottom fiange of I-beams
(5) Wall brackets for horizontal piping

Hanger Type

Type 16 Adjustable Wrought Clevis Type 34 DoublemBolt Clamp

Type 37 Malleable Irbeam clamp

Type 23 Medium weight welded steel bracket

c. Ciamps for suspending piping from structural steel members, other than those specified in paragraph $b(4)$ above, shall be the following Grinnei? Co. products, or approved equal.
(1) Swinging top beam clamp - Grinnell Figure 270
(2) Universal channel clamp - Grinnell Figure 226

a. Camps for vertical offset piping shall be BlatwKnox Figure 138, or Exproved equal.

e. Hanger rods shall be Grinnell Company Figure 278 Welded Eye Rod, or Grinnel1 Company Figure 140 Machine Threaded Rod, or approved equal. Hanger rod sizes not shown on the drawings shall be in accordance with ASA B3I. 1 , Section 6 , Chapter 1 , with minimum rod size for single-rod hangers as follows:

$$
\begin{aligned}
& \text { Pipe Size } \\
& 2^{\prime \prime} \& \text { smaller } \\
& 2 \frac{1}{2} ", 3^{\prime \prime} \& 3 \frac{2}{2} \\
& 4^{\prime \prime} \& 5^{\prime \prime} \\
& 6^{\prime \prime} \\
& 8^{\prime \prime}, 10^{\prime \prime} \& 12^{\prime \prime}
\end{aligned}
$$

Rod Size

f. Concrete inserts, where required for support of piping, shall be "Unistrut" F-3200 Series or P-1000 Series with "Unistrut" Spring Nuts, ox approved equal. AlI inserts shall be complete with end caps and wsxed cardbosrō fillers.

\section{I5. PIFE INSUTATION}

\section{I5.I INSIDE BUILDING}

a. Insuiation for steam and condensate lines not embedded in concrete shall be a premolded, sectịonal, hydrous calcium silicate pipe covering conforming 


\section{I5.2 INSINE BUITDING}

a. (continued)

T,S Federai specification HH-Io523a, Class 2. The insulation shall be furnished with a factory-applied, 8 oz. white canvas jacket. Cement tor forming insulation covering over fittings and valves shall conform to $H H=I-5232$, Class 3 .

b. Ingiation for steam and spare ines embedded in concrete within the buifding and for hot sanitary water ifnes (HSW) shall be a preformed: ateionis glass fiber material conforming to Federal specification yi-.-562, Type II, Class 1. The insulation shall be $1 / 2$ inch thick for ail pipe sizes and shali be furnished with a factoryapplied, iaminatel inaft paper and foil (universal) jasket with white finish, lap cement Ior thiz material shall be Owens-Corning Co. "Vapor Barrier Cement". or foproved equal.

c. rape, for seeling longituduna and transverse laps of insulation jacket or steam and spare lines embedded in concrete, shall be polyethy?ene adresive tape at least $20 \mathrm{mils}\left(0.020^{\prime \prime}\right)$ thick, Folyken No. 920, or siryored equal.

4. Anturweats covering for cold sanitary whter (sw), cold process water and rew water (RW) lines except in Cold Canyon shall be the same as spesified in paragraph b. ebove except that it shall have a factoryo Explied dual temperature jacket formed by laminsting kraft paper and 10:i. Jacket shall be fire retardant tyce snd shall have a white finish.

e. Insulation for chilled water lines (CW) shall be a preformed, sectioral, Flass faber moterial conforming to Federal specification HH-I 0562 , Type II, cless 2. The irsulation shall be $3 / 4$ inches thick snd shall be covered with a dual temperature iacket of the type descrike a revagrapi c. above.

f. Iagging adhesive shail be Benjamin Foster Co. No. 81-42W, or axprovea equal.

\subsection{OTSTEE BUIDING}

a. msulation for underground steam and condensate innes shall be inghtw wat aght agregate (rermicuite) concrete enolosed in a piastic water risofing membrane of PVO or poiyethylene st least 0.020 inches an thoskness。 


\subsection{OUTSIDE BUIDDINis (Continued)}

b. Inswlsting corcrete shail corsizt of expanded vermieuilte aggregate,

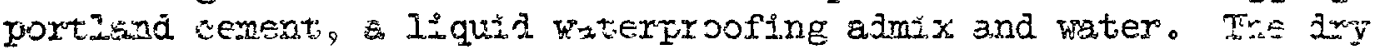
dersity of the mixed materjal after settiog, shais not he grester then 25 Ib. Ker exbie foot. The Lnsulatiog concrete ahall have a compressive strengtin of rot iess than 75 EE⿰ $e^{+} 28$ days when tested ia standara sizei teet cyininders.

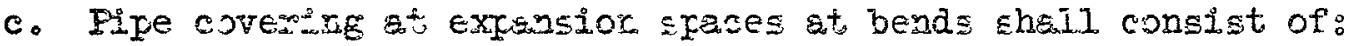

(i) A one Ench thick iayer of molded sectionai, minexsi waz

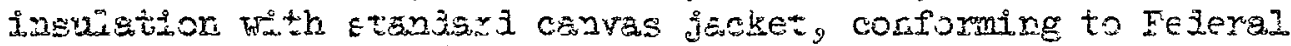

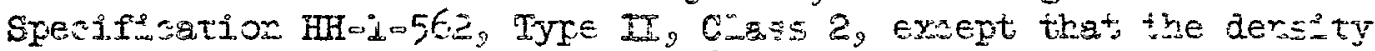
of the material shali not exced 8 pef.

(2) A 2oinch thickness of minerei yool bianket type insuigt:on, kaving a density not grester than $301 / 2$ fat and conforming to kejerai

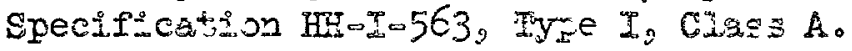

(3) A teterproof jacket of ierineted foil chd kraft parex; or s visero

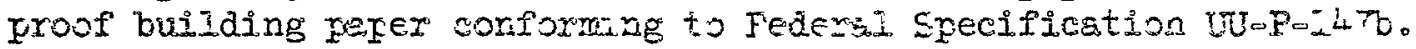
Tape for jacket joints shall be 2 inch wode, waterproof, adhesive taxe suitable for tre jokket usta.

d. Pife covering to frevent bord ber ween the fife and insuiating zartete shsil be a corrugated or inden ea abezis purer material sonforring to $F \in d e r a l$ Specification HHoI-56I, Type I, Caas 2 .

e. Insulating conerete shain corform to the requirements of the Vermicuste

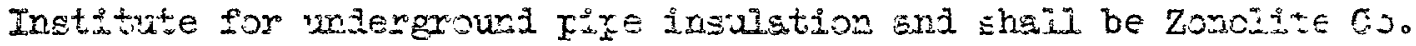
"Zucrete", or aprorod egusis.

\section{TANK INSUIAWEN}

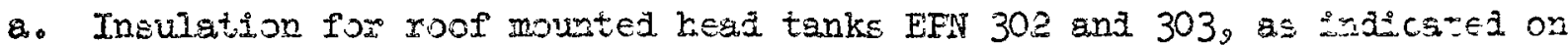
dratring H-3-20476, sheid be one inch thick giass w001 blaniset, conforming

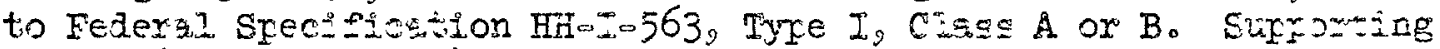

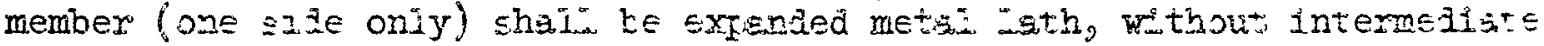
ribs, wej.ghing $\hat{\varepsilon} .0$ to $2.5 \mathrm{lb}$. IEz s zware yard.

b. Insulating eement for coverang zosulation shali be Owensocorning Fiberglas Corp. "Oun" insulating cement, or srproved equal.

c. Ciss cisth for resuforing membrane, shall he Guensworning Fibergies Corp. Open Wesve Gisss CI $\mathrm{L} \mathrm{h}_{2}$ or epproved equil. 
16. TANK INSULATION (Continued)

d. Weathercoat material shall be a vinyl mastic in light gray color, Vimasco Corp. "Vimasco"; Benjamin Foster Co. "Sealfas" Mastic No. 31-22, or approved equal.

17. PLUMBING FIXTURES

17.1 WATER CLOSETS

a. Water closets shall be wall mounted, vitreous china, siphon jet with elongated bowl, $1-1 / 2$ inch top spud, exposed flush valve and white open front seat without cover. Water closets shall be American Standard "Glenco" No. F2495 8, or approved equal, with white "Mol-Tex" 9500 seate.

b. Flush valves for water closets shall be chromium plated with oscillating handle, screw dxivex stop, flush connection, and coupling for $1-1 / 2$ inch top spud. Flush valves shall be Sloan Valve Company No. 112 IV "Royal", or approved equal, equipped with vacuum breaker, SIoan Valve Company No. Vol00-A, or approved equal.

c. Closets shall be mounted on Zurn Zw1205 or Zw1208 Series wa.11 closet carriers and fittings, or approved equal.

\subsection{URIINATS}

a. Each urinal shall be wall hung, vitreous china, siphon jet with a winch threaded outlet connection, integral trap, l-1/4 inch top spud, and individusl exposed flush valve. Urinals shall be American Starjard "Alta", No. F-6240-I, or approved equal.

b. Flush valves for uringls shail be chromium plated with oseiliating handle, screw drivex stop, flush connection for $1-1 / 4$ inch top spul, and vacuum breaker. Flush valves shall be Sloan Valve Company "Royal" $180 \mathrm{YV}$ wi.th vacuum breaker, or approved equal.

c. Urinals shall be mounted on Zurn Z-1217 wall fixture carrier, or approved equal.

\subsection{IAVATORIES}

a. Lavatories shall be vitreous china, 20 inches by 18 inches with $4-1 / 2$ inch back, and concesled wall hanger. Lavatories shall be complete with combination supply fitting with aerator and pop-up drain. Adjustabie 1-1/4 inch $P$ trap, and $3 / 8$ inch supply pipes with stops to wall shail be American Standard No. R-7000-44 and R-2604 respectively, or approved equal. 


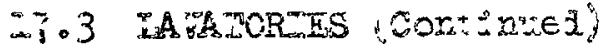

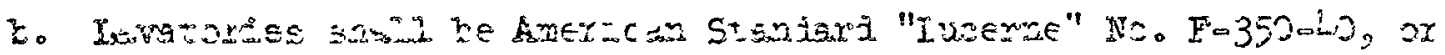

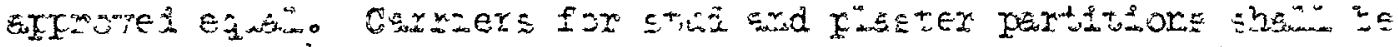

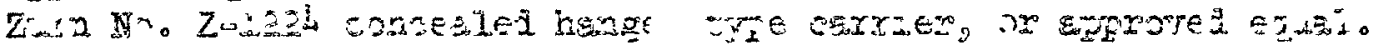

\section{2?.4 STOWER GARSETS}

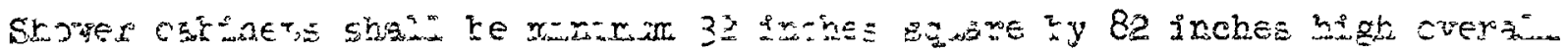

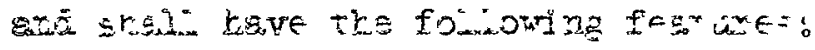

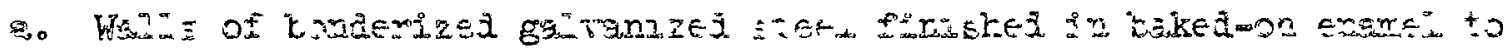

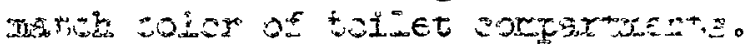

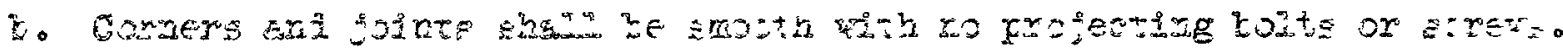

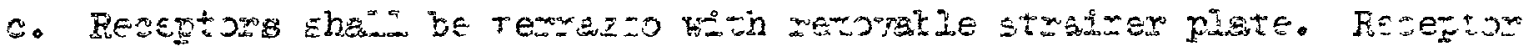

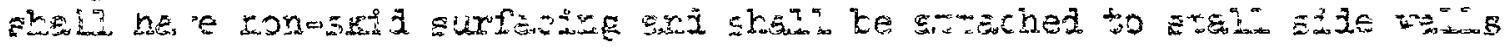

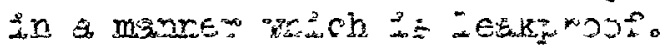

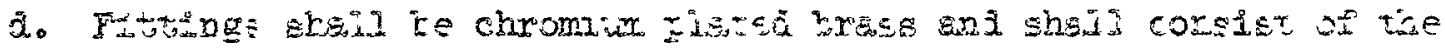

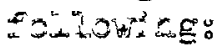

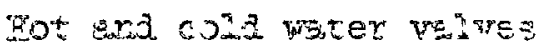

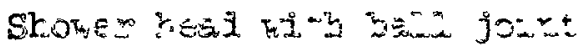

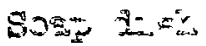

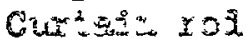

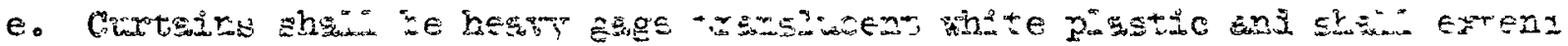

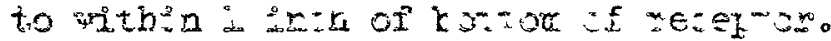

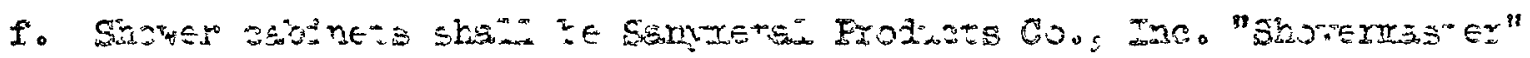

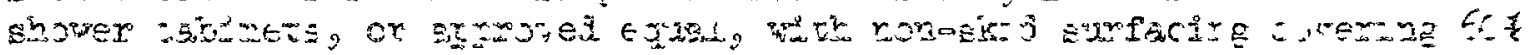
of stsmatre

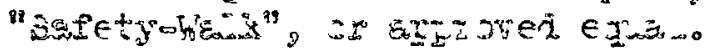

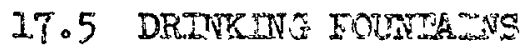

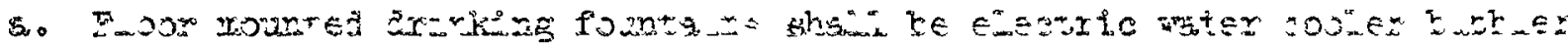

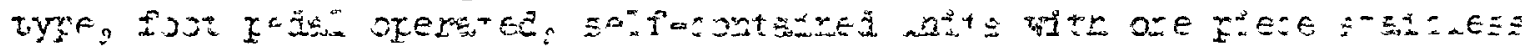

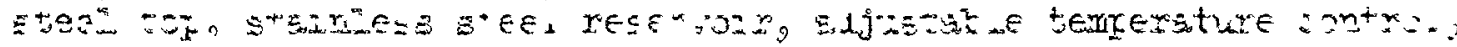

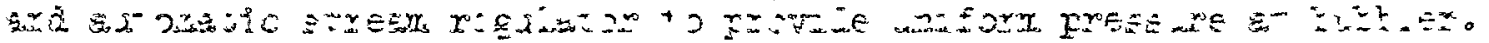

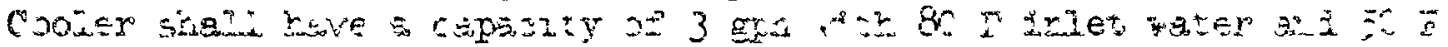
J_tet :

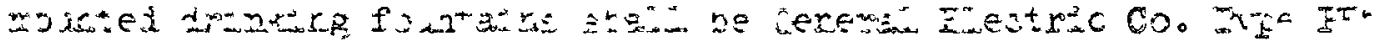

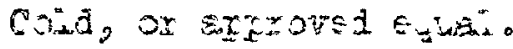




\subsection{DRINKTNG FOUNTATNS (Continued)}

b. Wall mounted drinking fountain shall be the same as specified in paragraph (a) above, except it shall be push-button operated. Wall mounted drinking fountaia shall be General Flectric Company, Type PW6 Cold, or approved equal.

\subsection{SERVICE SINKS}

Service sipks shsill be vitreous enameled cast iron, 20 inches by 24 inches with 12 inon high back. Sinks shall be complete with adjustable floor mounted trap and zouble faucet with bucket hook and hose end spout.

Sinks shall be American Standard "Argc", No. P-7700-1, or approved equal.

\section{$17 \cdot 7$ WASH FOUYMAIIS}

a. Circliar wash fountains in the change rocin shall be precast $\mathrm{s}^{+}$one approximately 36 inches in ciametew by 30 inches high to rim of bowl, complete with liquid soap dispenser wi-h 5 outlets. Supply shall include circular water distributicn sysiem, mixing valve and circular foot-operated bar Wash-fountixs shall rave removable panels around the standard to permit ready access to mixing valve and operating valve. Supply piping will connect from below and vent will connect from above. Pedestal housing shall be pale yellow in color. Washfountains shall be Bradley Washfountain Co. No. HEB "Granito", or approved equal.

b. Eyewash fountains to be installed adjacent to safety showers shall be a pedestal mounted, foot-tresile operated fountain for flooding the eyes. The sprayheals or nozzles shall be chrome plated. The bowl shall be porcelain enameled iwon. The pedestal pipe and floor flange shall je galvanized or baked enamel finished. Eye-wash fountains shall be Haws Drinking Faucet Co. Model No 7120, or approved equal.

\subsection{HOT SANITARY WATEP HEATERS EPN-837}

a. Sanitary hot vater heaters shall be 80 gallon storage capacity, elecrxically beated. The tanks shall be galvanized on the extexior and shall be glass-Iined, with I" NPI connections. Tanks shall be insulated and jacketed.

b. The water heaters shall $\mathrm{ke}$ equipped with a minimum of two 240 volt, 60 cycle AC heating elements of the ary-well or strap-on type. Each element chall have individual themostatis control. Upper element shall be 2000 watts and lower element 3000 wat.s 


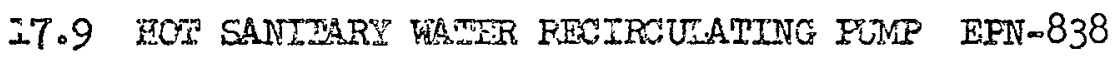

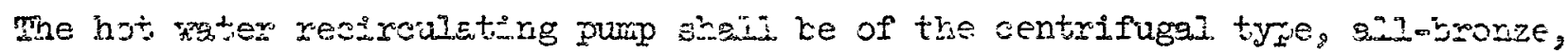
soriosion resfetant construction, Nith direct connected motor designed for

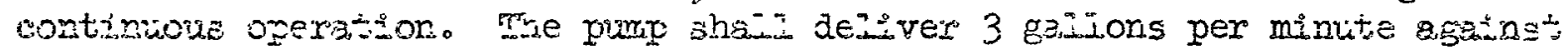

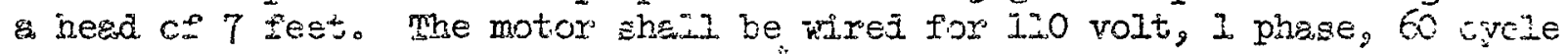

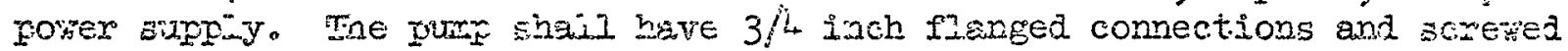
comparion finges。

Tre gurp sheil ke Eel1 \& Gossett Co. Booster Pamp No. 75, or epproved equez.

18. $2 \mathrm{PEE}$ SIEEFE EEETANZ

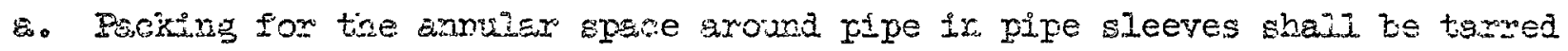

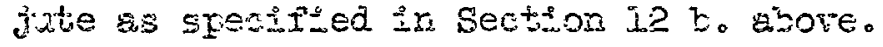

b. Seeisin for ends of pipe sieeves shain be a polysuiphide rubber comroind conforming to the requxerenis of A.SA AII6.2.

19. KLFE FIOTS AND CAPS

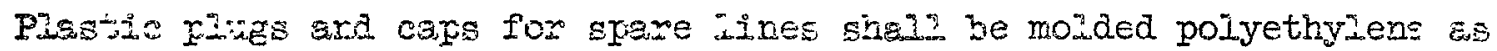
produced by the Capiugs Divo of the Frotective cossures Co. Inc., or approved equas?

20. SAMPLER RMP - ERN - $=T P P$

2. Whe punp shain be a stainiess steel, canned rotor, centrifugai pump to meet the foilowing specifications:

\begin{tabular}{|c|c|}
\hline Caxanity & - $40 \mathrm{gpm}$ \\
\hline Discharge Prescure & -50 feet \\
\hline Suction Pressure & Fionde \\
\hline Pumping Tenperatue & 90 \\
\hline $\mathrm{N}, \mathrm{F} . S \cdot \mathrm{S}_{0}$ & 30 fee: \\
\hline SFEOIfic Srevity & 1.2 g-rerage \\
\hline $\mathrm{V}^{2}-$ scosity & ent:polses \\
\hline Lons & - Flazged \\
\hline
\end{tabular}

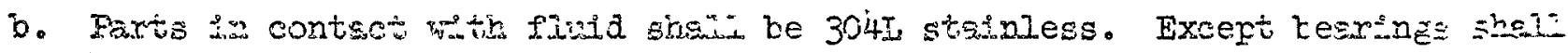

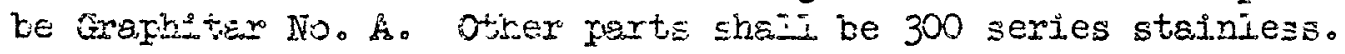

c. Motor ebsic be for 440 roit, 60 sycieg 3 prase curreat.

d. Processufludoiviruogated besrings with screen for lubricant by-pasz sme xequired. 
20. SAMPLER PUMP - EFN-1TTP (Continued)

e. Pump ghail be Footoria Corporation, Chempamp Model $G$, to meet the above roguirements, or aprroved equei.

2i. NTTRTC ACID PUMP - FPN-2IIP

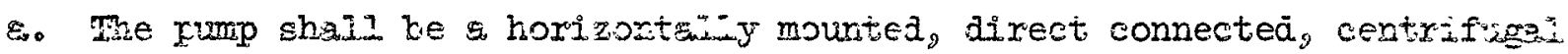
pump to meet the following requixements:

FIos

Discharge pressure

Suction preszine

Fumping perperstive

Specific gxartity

Bump matexiac

Fump Conections
25 gpm

35 peig

Filooded

20-80 $\mathrm{F}$

1.375

Worthete or Exion

150\# ASA Flarge

Shaft Ses?s - Water seal with drip pan and drsin

Motor - 440 rolt, 60 cycle, 3 fhase totaliy encilas

b. Unit shsil be Worthington $3 / 4$ CNG 42 , to meet the obove requirements, or epproved equal.

23. FTASH TANK - EPN-84

\&. The vessel shall be a vertical cylindrical vessel $16^{\prime \prime}$ diameter $x 6^{\circ}-0^{\prime \prime}$ height plus bese with nozzles sized and located approximately gs $\$$ hotr on drawing H-2-20485. Whis shai include iniet, autlet, cordensste outlet, inspection and drein ports.

b. Tessel sineil be designed, frabrozted snd stampd as an ASME coze

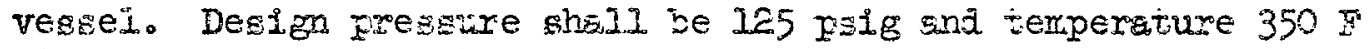

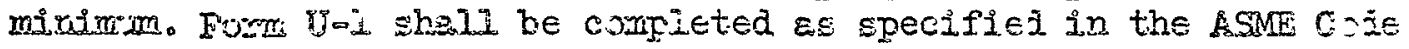
for Unfired Pressure Vessele, and shell be made available to the Commiosion.

23. SIMTIESIBIE PIUP - EEYY - 842

a. The tume shall be a submersible deep weil turbine pump to west ths folioring requirement:

Capactity

Discharge prescure at top of yeid

Inlet pressure

Motor current

Well casirg aize
$50 \mathrm{grm}$

$5 \mathrm{Fsig}$

Fiooded

440 rolt, 60 cycle, 3 phs $=\varepsilon$

$6 \mathrm{inch}$ 


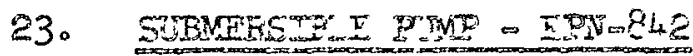

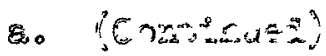

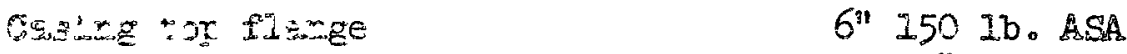

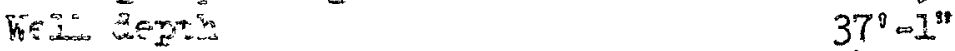

$$
\begin{aligned}
& \text { Dextin to }
\end{aligned}
$$

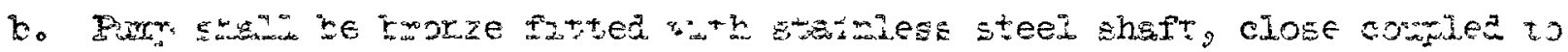

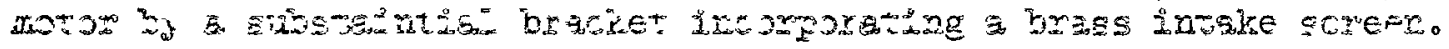

c. SEs

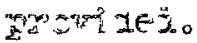

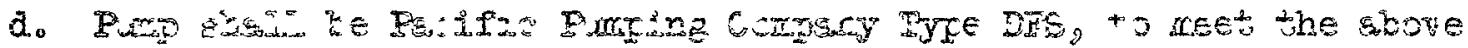

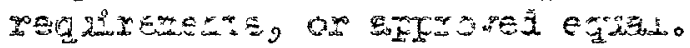

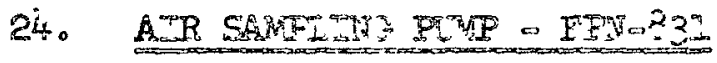

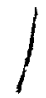

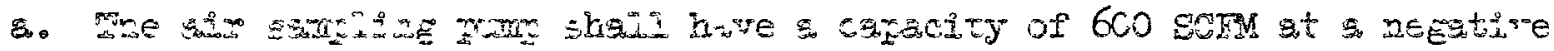

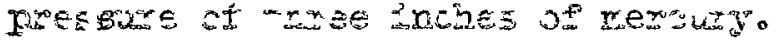

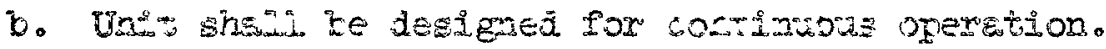

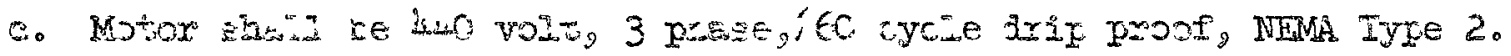

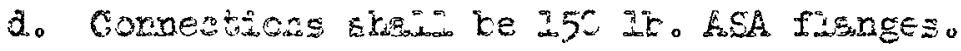

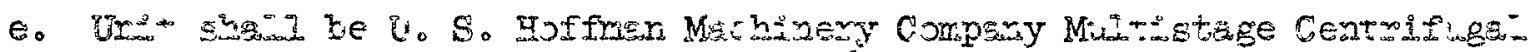

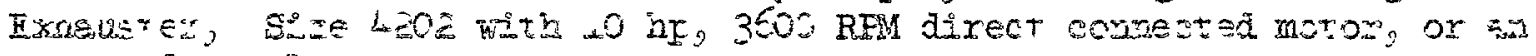

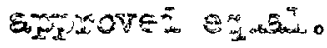

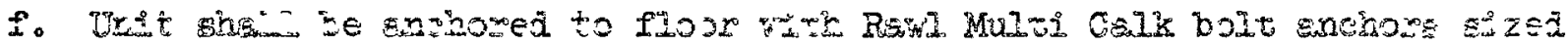

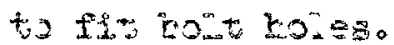

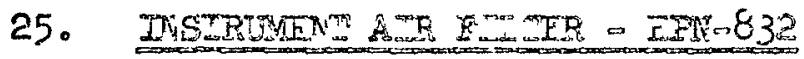

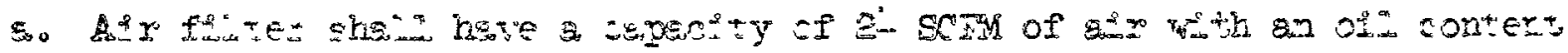

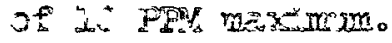

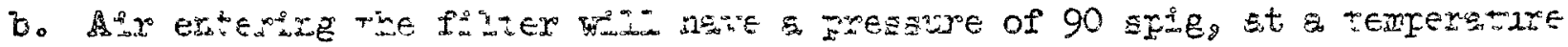
of 70 I

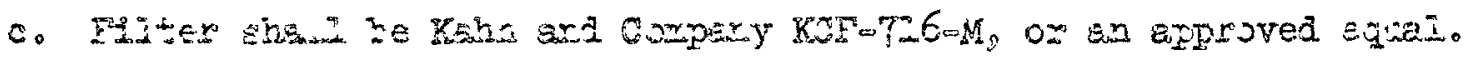


26. INSTRUMENT AIR RECEIVER - EPN-833

a. The vessel shali be a vertical, cylindrical, compressed-air receiver $2-1 / 2 \mathrm{ft}$. dia。 $x 5 \mathrm{ml} / 2 \mathrm{ft}$. tall with nozzles located approximately as show on H-3-20485. Nozzies shall include inlet, outlet, drain, safety valve and inspection ports.

b. Vessel shall be designed, fsbricated, and stamped in accordance urith section VIII of the ASME Code.

c. Design preasure shali be 125 psig minimum.

d. The safety valve shall meet ASME Code requirements and shall be provided pre-set at 110 psig for an expected working pressure of 100 psig.

e. Forms U-I and Uo4 shall be completed as specified in the ASME Code for Unfired Pressure Vessels and shall be made available to the Commission for permanent record.

\section{BUIIDING AIR RECEIVER - EPN -834}

a. The ressel shall be a vertical, cylindrical vessel $3 \mathrm{ft}$ in diameter $x 8 \mathrm{ft}$. overall height, with nozzles located approximately as shown on $H-2-20461$. This shall include inlet, outlet, drain, inspection and safety valve ports.

b. Vessel shall be designed, fabricated and stamped in accordance with Section VIII of the ASME Code.

c. Design pregsure sheil be 225 psig minimum.

d. Safety valve shall meet ASME Code requirements and shall be provided preset at 110 psig for an expected working pressure of 100 psig.

e. Forms U-I snâ U-4 shall be completed as specified in the AsMF Code for Unfired Fresaure Vessels and shall be made available to the Commission for permanert record.

28. EUTIDINC VACTUM PIMP - EPN-835

a. The pump shali have a capacity of 135 ofm at an absolute pressure of 6 inches of mercury.

b. Parts of pump in contact with gases shall be made of materials resistant to acid and other laboratory vapors. 
28. BUTLDNG YHCUTM POMP - EPN-835 (Continued)

c. Quiet and vibration-Iree operation of the unit is essential. Pipe corriections shali be $150 \mathrm{Ib}$. ASA RF flanges....

d. Urit shal1 be Beach-Russ Company, Type RP, Class W, to meet the above requirements, or approved equai.

29. BUIIDING VACUUM RECEIVER - EPN-835A

a. The vessel shall have dimensions as shown on Detril II - H-3-2048I.

b. Tessel shall be designed for operation at full vacum.

¿. Support brackete shall be sized to support vessel full of water.

d. Material shail be commercial grade Type 304I stainless steel.

e. All nozzles shall be provided with 150 Ib. ASA RF flanges.

30. VACUUN FIUIER - EPN-835B

a. Filter shall be sized to be supported by a single end flange between two $12^{\prime \prime} 150$ 1b. A.SA RF flanges.

b. Capacity shall be 150 SCFM at less than I" WG pressure drop.

c. Efficiency shall be $99.97 \%$ on the U.S. Chemical Corp. test using 3 micron diameter DOP particles.

d. Tigter shall be Mine Safety Appliances Co. Catalog No. CU 85175, or spproved equal.

31. SUMP PIMP - EPN-836

a. The pump shall he a vertical shaft, flange mounted, heavy duty, butconatie sump pump designed to pump $50 \mathrm{gpm}$ of water at a head of $20 \mathrm{ft}$.

5. Lergti from bottom of mounting flange to bottom of pump shall be suitabie for sump 60 inches deep.

c. Motor shall be 440 volt, 60 ejcle, 3 phase, dripoproof, ball bearing motor.

d. Pimp discharge connection shal1 be $11 / 2$ ". screwed. 


\section{SIXP PMP - EPN-836 (Continued)}

e. Frmp shaft, impeller and couplirg shall be carried by a grease packea, deep groove, self aligning, radial thrist, ball bearing in dust proof housing machined in motor support base.

f. All material in contact with the liquid pumped shall be stainless steel or corrosion-proof in $20 \%$ nitric acid service.

go Sump cover shall be gas tight and sized for a sump 36 inches square. Sump cover shall be provided with a $12^{\prime \prime} \times 16^{\prime \prime}$ manhole having a cast iron eover and flanged vent connection.

2. Contiol equipment shali consist of an enclosed, automatic, heavy-duty floss switch, mounted on rigid support bolted to sump cover and cotuated by a finot or cisplacement weights.

¿. Tnit shali be Pacific Prmping Company Type SI, heavy duty sump pump modified to meet the reguirements stated above, or approved equal.

32. 配FER METIRS

\subsection{ALIONAIIC STOP WATER METER - EPN-843}

Max. Pressure: 125 psig

Lirection of flow: left to right facing meter dial

Connextions: $2 " 125$ 10. flat face flanges

Materiais: Compostion Bronze casting, gears and measuring chamber. Body and cover of auto stop ralve shall be cast iron.

Iempereture: Coid water, less than $80 \mathrm{~F}$.

Uxitis of measure: Std. calibration in U.S. galions

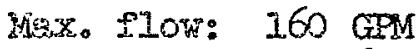

Miximum fiow: $16 \mathrm{GPM}$

kegister: Automatic stop feature with 1 to 9999 gal. pushbutton preset and I to 9999 indicsting counter. When preset gravity flows through meter, the register shuts off flow and actuates electric switch below. No ticket printer is required. Register shall be manual reset.

Automatio Shitch: The rating of this switch shall be 15 amps, 125 volts AC and shall dose circutt when preset quantity is reached or registe:. Eepresentative Type: Neptune Meter Compsry, Type $S_{2}$ Model 432. RLES: FEN 324-843

\subsection{STYOMATC STOP WATER METER - EFN-844}

Gime as EIN-843 except:

Cornectiors: $3^{\prime \prime}-125 \mathrm{Ib}$ - flat face fianges

Disection of flow: Right to left facing meter dial

Bisximiar Flow: 300 GFM

Minimum Flow: 25 GPM

Rerv: ET:N 324-844 
32. WATER METERS (Continued)

32.3 ATTOMATIC STOP WATER METER - EFN -845

Same ss EFN-843 except:

Connfotions: $3^{\prime \prime}$ - 125 lb. flat face fianges

Msximm FIOW: 320 GFM (Infrequentiy)

Mninirum Filow: $25 \mathrm{GPM}$

Mark: EFN 324-845

33. AFEON MANEFOLD AND RESULAFOR ASSEMBIY - EFN -857

The argon manifo"d and reguiator assemby shall include: (1) Al工 the fiturngs zad connestiors necessary to connect two exgon cylinders to the manifo-d, (2)

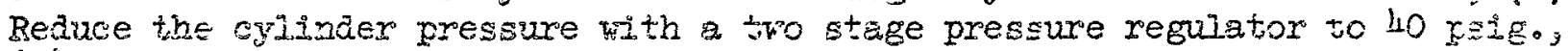
(3) Frotect the builiting sxgon piping fith a pressure relief valve set at 50 psig.

- Refresentative Type: Linde Company parts as follows or equal:

I - $25 \times 17$ Control Assemily

1 - $05 \times 04$ Regulator (Iype RG64)

1 - 60 I 11 Inlet Adspter

I - 60 I 14 outlet Irube

$2-25 \times 36$ cyinder Leads

2 - II P 64 Reilef Valve (Tyge RV 29) set at 50 psig

Mark: EEN 324-857

\section{WORKMANSHIP}

\section{DNSTAIIATION OR FIPING}

34.1 GENERAL

c. AiI piping staII be fabricated and irstsiled in accordance with ASA BY:and ASA ALO.8, withever is applicable, the Piping Codes, the dritrn: and these specifications. Weldzng of pressure piping is specufied is Division $Y$, Sestion 7 .

b. Where supports are not indicated specifically on the drawings, hangers shall conform to the requirements of section 14 above and spacing of such supports shail conform to spacings suggested in ASA B31.1, Sect,an 6. Table 21A.

c. Open ends of piping shall be kept plugged or capped when erection is not in progress to prevent the entry of dirt and other foreign material. 


\subsection{GENERAL (Continued)}

c. Conflicts in design locations of piping vith ductwork, lighting fixtures, etc., shali be promptly reported to the conmission.

e. Valves, equipment and accessories shall be installed where and as shown on the drawings.

f. Chrome plated, spring loaded, escutoheon plates shall be installed at piping penetrations in non-process area floors and at all piping penetrations in plaster partitions.

g. A.I threaded jointe in piping systers shail be made with joirt seaiant tape. Burrs shall be removed from mating threads before assembly. AlI fieldovut pipe shall be reamed to nominal inside diameter.

h. Kaised face flanges shali not be connected to flat face filanges.

i. The ends of epsre lines shail be fiugged or carped. In the case of spare lines from the trench in the Cold Canyon to the outside of the building, the inner ends shall be fitted with polyethylene plugs and the ends outside the building shall be capped with polyethylene caps. Caps and plugs shall fit watertight. Spare stainless steel line: shali have pipe caps weladed on ends. which occur inside the process cells.

\subsection{STEAM PIPING}

a. Steam piping, inside the building, shall be sloped 1 inch in 16 feet in the direction of flow, except where shown otherwise on the drawings. Steam lines shall be free from low points or pockets, where coniensate could collect, except at designated stations where traps are provided.

b. The inside of all pipes, valves, and fittings shall be smooth, alear, and free from blisters, mill scale, sand, debris and dirt when erected. Ali lines shall be cleaned after instsilation and before placing in operstion. strainer ecreens shsll be replaced after cleaning and flushing. (See Sec.39)

\subsection{CAST IRON WAIER PIPING}

a. Cast iron pipe, fittings, and valves shail be handied with care at ail times to avoid damage of any kind to the materisis or its costing. Damaged material shall not be included in the inatallation. Damage to pipe coating shall be refaired to the satiefaction of the Cormission. Under no circumstances shall pipe or accessories be dropped or dumped. 


\subsection{CAST IRON WATER PIPING (Continued)}

b. Csist iron water piping shall be laid on a bed of compacted or un. disturbed sand not less than 4 inches thick under the bottom of the piping. Bell holes shali be prepared so that the pipe is supported along the full length of the barrel.

c. Interior of pipe fittings and accessories shall be kept free from dirt or other foreign matter at all times.

d. Before lowering pipe into the trench and wile still suspended, esch pipe section shall be inspected for defects and rung with a light hammer to detect cracks. Defective or damaged pipe shall not be used.

e. Pipe shall be laid and maintsined to the lines and grades shown on the drawing with fittings and valves at the required locations.

f. Joints in mechanical joint cast iron piping shall be made in strist conformance with the pipe manufacturer $s$ recommendations and "Notes or Methods of Installation" given in ASA A21.11.

\subsection{VIFRTFIED CIAY SEWER PIPING}

a. Pipe shall be protected during handing, against impact shocks and dropping. Immediately prior to laying, the pipe shall be inspected and any damaged sections shall be discarded.

b. The laying of pipe in finished trenches shall be started at the lowest point of the run and progress upgrade with spigot ends pointed in the direction of flow. Trenches shall be free from standing watex when jointing is in progress.

c. All pipe joints shall be carefully centered so that when the pipe $1 \equiv I=z^{2}$; sawer with aniform gradient will be formed. Bell holes shall be prepared so that the pipe is supported along the full length of the barrel.

\subsection{CAST IRON DRAIINAGE PIPING}

At the point where the drainage system from the gallery around the Metallurgical Cells joins the Crib Waste Sewer, the spigot end of the drainage piping shall be fitted into the large end of a stainless stee. reducer. The joint shall be packed with tarred jute, poured with hot lead and calizked. 
35. INSTALTATION OF PLUMBING FIXTURES

a. Installation of plumbing fixtures specified in this division, sanitary drains and vents within the building shall conform to the requirements of A.SA A 40.8 .

b. For wall hung fixtures, the support stands shall be "roughed in" when the floor slab is placed. The foot plates shall be fastened on the underside of the top mat of reinforcing steel to permit the instisiation of floor tile around the fixtures.

c. Supply piping for plumbing fixtures shall be installed with air chambers a minimum of 12 inches high to reduce water hammer.

36. APPLICATION OF PIFE INSULATION

36.1 INDOOR - CENEERI

2. After piping has been hydrostatically tested, the Comission will give notice that it is ready for insulating. The piping shall then be insulated, except that for steam lines, the flanges, fittings and valves shall be left uninsulated until the line has been tested at operating conditions. Approval of the Commission is required before insuiating the flanges, fittings and valves.

b. Pipe surface shall be free of water, oil, dirt, loose scale or other foreign material before application of insulation.

c. Insulation shall be of uniform thickness and shall fit snugly to the surface to which it is applied. Any insulation that is damaged or doss not fit properly shall be replaced.

d. Insulation shall be installed in a neat, uniform and workmanike msnner with joints tightly butted and sll joints staggered between layers of doublemlayer insulation.

e. Pipe insulation shall be teminated a sufficient distance from flarges to permit removal of bolts.

f. Hagers which are in direct contact with the pipe shall be covered with the pipe covering. Where necessary, part of the inside surface of the insulation shall be removed to maintain the continuous line of coverang.

g. A.II insulation and cements must be thoroughly dry before sealing.

h. Markings on safety and relief valves or rupture disks shall not be covered. 


\section{6.i IIDDOOR - CENERAI (Continued)}

i. Condensate lines shall be insulated only where they occur within $i$ feet sove building fioors, unless shown otherwise on the drawings.

1. Tracer and recirculation lines shall be insulated in the same insuiation exrelope ss the main they follow. Insulation may oe routed out at the Iongitudinal hinge to provide room for the accompanying tubing.

\subsection{INDOOR GIASS FIBER AND CAICIUM SIIICATE INSULATION}

a. Calcium silicate insuiatior shali be secured in place with not less ther for loops of vire per threemfoot section. The ends of the rire ings

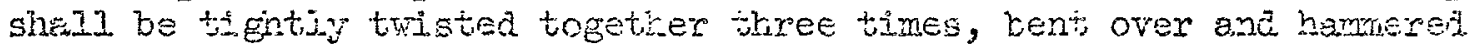
into the irsulation to elimirete proiections.

6. Pipe insuiation with smalz volds, such as broken corners, may be used, Fxovided that the volds do not exceed one equare inch in area and that trey are filied with insuiation meterial or astestos cement.

¿ Calcium silicate pipe insulation shail be covered with a troweied sat of asoestos cement to present a sniooth surface.

d. Insuation for pipe bends shail be pipe covering mitered into lergth thet fict neatly and smoothed with a troweled coet of asbestos cement.

e. Rloct insulation or pipe covering shall be applied over the body of mangeo fittings ar $\bar{x}$ ralves and shail be of sufficient thickness to make the OD of the insuletion equal to the oD of the adjacent flarges. is cover, consisting of pife covering or block insulation equal in type and thicirress to the adjacent pipe corerings sheit be applied orer the above insulation and over Iine fianges. Cover shali overlat the edjesent pipe covering not less than two jnches, or the pipe covering thickness; wichever is greater.

f. Irsuiction on flanges, flanged fittings and valves shali be given a trorreled soat of asbestos cement to presert a smooth aurface.

g. On pipe sizes four inches and larger, screwed and weloed fittings and valve oodies shall be insuisted rith biock insulatior or pipe covering and sorerea with asbestos cenent the same as for flanged fittirgs and valves. Oa pipe sizes less than four inches, screrea and welded fiutings and vaive bodies shall be corered with asbestos cement to a thickress equal to that of the adjacent pipe covering. The cenent shall be apulued in layers not exceeding $1 / 2$ inch in thickress. Ekch iayer shali te allowed to dry before applying the nexi layer and the final layer trowcled to a smooth finish. 


\subsection{TISULATION OF STEAM AND SPARE LINES IN CONCRETE}

8. Wass fiber insulation, for steam and spare lines to be embeddex in concrete within the building, shall be installed with end joints of preformed sections butted tightly together. Transverse and Iongitudinal laps shall be sealed with vapor barrier cement.

b. Insulation shall be double thickness at all bends and elbows and for 5 distance of 3 feet in each direction tangent to the bend or elboris.

c. Double thickness insulation at bends shall be spirally wrapped with polyethylene tape lapping turns one inch. Tape shall be started 6 inches back on single thickness insulation at each end of wrap.

d. Furatures or other damage to the vapor barrier jacket of the insulation shall be sealed with tape prior to placement of conerete around the piping.

\subsection{TNDOOR FINLSE}

8. Calcium silicate insulation shall be finished with an 8 oz. per aluare yard canvas jacket cemented smoothly in place with lagging cernent. Jecket for pipe shall have longitudinal and end laps of not less than tro inches. For pipe bends, flanges, fittings and vaives, the canvas shili be cut and stretched to fit and lap without wrinkles. The entire canvas surface shall be given \& brush cost of lagging cement. The orramenti. bsnds, usually furnished by the insulation manufacturer, shall not be issa.

b. The insulation jacket on hot sanitaxy water lines shall be cemented sad stapled. Transverse joint strips furnished with the insulstion stais be useà.

c. The insulation jacket on cold sanitary water lines and chilied wetex iines shail have the laps and joint strips sealed in place with varox barrier cement. Metal bands shall be appiled at the center of each section sin at the edges of the joint bands until the cement has dried. Eads of insulation shail be sealed off with cut back asphilt mastic at ail flanges, valves and fittings and at intervals of not more than 2 i feet on continuous runs. Insulation on flanges, valves and fittings shali be coated with a brush cost of white vapor barrier cement followed by an application of $8 \mathrm{oz}$. canvas and second cost of white vapor barriex vement.

\subsection{PEPTNG INSTLATION THICKNESS SCHEDUTE}

Insulation on indoor pipe lines shall be of the materials and the thickneszes shown in the following schedule. 
36.4 PIPTNG INSUIATION THICKNESS SCHEDULE (Continued)

\begin{tabular}{|c|c|c|c|c|}
\hline Service & $\begin{array}{l}\text { Piping Code } \\
\text { Number }\end{array}$ & $\begin{array}{l}\text { Insulating } \\
\text { Material }\end{array}$ & $\begin{array}{l}\text { Pipe } \\
\text { Sizes }\end{array}$ & $\begin{array}{l}\text { Insulation } \\
\text { Thickness }\end{array}$ \\
\hline $\begin{array}{l}\text { Stesm and } \\
\text { Condensate }\end{array}$ & $\mathrm{H}-10, \mathrm{H}-14$ & Calcium Silicate & 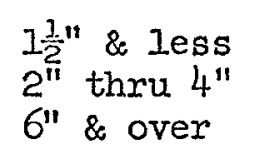 & $\begin{array}{l}I^{\prime \prime} \\
I^{\frac{1}{2}} \\
2^{\prime \prime}\end{array}$ \\
\hline $\begin{array}{l}\text { Hot sanitary } \\
\text { watex \& hot } \\
\text { process water }\end{array}$ & $\mathrm{H}-12$ & Glass fiber & A]I & $\frac{1}{2} "$ \\
\hline $\begin{array}{l}\text { Cold sanitary } \\
\text { water, raw water } \\
\text { and cold process } \\
\text { water }\end{array}$ & $15-12$ & Glass fiber & $\begin{array}{l}1 \frac{1}{4} " \text { \& less } \\
1 \frac{1}{2} " \text { \& larger }\end{array}$ & $\begin{array}{l}\frac{1}{2} " \\
1 "\end{array}$ \\
\hline Chilled water & $\mathrm{H}-3 \mathrm{I}$ & Glass fiber & $\begin{array}{l}\text { I" \& less } \\
I_{\frac{1}{4}} \| \text { \& Over }\end{array}$ & $\begin{array}{l}3 / 4^{n} \\
I^{\prime \prime}\end{array}$ \\
\hline
\end{tabular}

37. INSTAZIATION OF UNDERGROUND PIPE INSULATION

a. Insulating concrete shall be placed on a structural concrete slab which in turn shall have been placed on undisturbed earth or compacted backfill and cured for at least 7 days.

b. The plastic waterproofing membrane shall be laid directly on the concrete foundation slab and the pipe support biocks placed on top of the membrane. The height of the pipe support blocks shall be adjusted to preserve the gradient of steam and condensate lines as shown on drawing H-3-20154.

c. After the piping has been fabricated the asbestos paper wrap shall be placed around each pipe individually and tied in place with hemp twine or i8 ga. galvanized wire. Ties shali be placed at laps in paper to prevent entry of insulating concrete mortar.

d. Iight density glass fiber insulation shall be placed around the steam and condensate lines to a thickness of 3 inches at elbows to provide room for expansion when the lines are placed in operation. Glass fiker insulation shall extend 10 feet in each direction from the elbow. The first layer of insulation shall be premolded material, I inch thick, of the type specified in Section 15.2c herein. The outer covering shall be blanket type material as specified in Section 15.2c. and shall be a single layer 2 inches thick or a double wrap of one inch thick 
37. INSTYLTATION OF UNDERGROUND PIPE INSUTATION

a. (Continued)

material. If the blanket type insulation used has a foil jacket this may be used as the waterproofing; otherwise a jacket of waterproof paper shall be applied. All laps and punctures in the jacket shall be sealed with waterproof tape to prevent entry of mortar into the insulation.

e. Insulating concrete shall be placed around the two pipes to the dimensions shown on Section $A-A$, drawing $H-3-20153$.

f. As soon as the insulating concrete has set, or in approximately 2 hours after placement, the waterproofing membrane shall be folded over the top of the encasement and lapped. A second strip of plastic membrane, 3-1/2 to 4 feet wide, shall be laid along the top of the encasement to cover the lap and prevent entry of ground water. Where piping penetrates concrete walls the membrane shall be flared out and cemented to the concrete wall surface. Any punctures in the waterproofing membrane shall be patched.

38. IDISTITATION OF OUTDOOR TANKS

a. Outdoor distilled water and caustic storage tanks, EPN 302 TK and 303 TK shall be insulated with one-inch-thick glass wool blankets having expanded metal support.

b. Metal mesh blankets shall be laid over the exterior surfaces of the tanks and the metal mesh of adjacent sections laced together with 16 gauge galvanized wire. Wires shall be pulied tight to eliminate sags and buiges. Wires may be placed across the tops of the tanks to aid in supporting insulation on the sides.

c. The insulation shall be covered with a $1 / 2$ inch thick coat of insulating cement, troweled smooth.

d. After the cement has aried thoroughly a $1 / 8$ inch thick coat of vinyl mastic shall be applied by "palming" or troweling. While the mastic is st1ll wet a layex of open weave glass cloth shall be embedded in the inastic. When the first coat has set, a second $1 / 8$ inch thick coat shali be applied for finishing. Coats of vinyl mastic shall not be applied when the ambient temperature is $40 \mathrm{~F}$ or below.

39. HYDROSTATIC TESTING

Piring shal be pressure-tested in conformance with the Piping codes and the following: 


\section{HYDROSTATIC TESTING (Continued)}

a. All instruments, facilities, and labor required to conduct the tests shall be furnished by the Contractor.

b. Testing shall be performed under the direction of and to the satisfaction of the Commission.

c. Testing shall be completed before pipe insulation is applied to above ground lines and before backfilling is completed over lines to be buried and before concrete is placed around lines to be embedded.

d. Prior to testing, all chips, dirt, and debris shall be flushed out of piping. strainer screens shall be removed during flushing.

e. Air shall be expelled from lines prior to applying test pressure.

f. Pressure in section of piping undergoing test shall be slowly raised to the specified test pressure.

g. All piping, fittings, and joints shall be carefully examined during testing and valves shall be checked for proper operation. All visible leaks shall be repaired.

h. AII repaired piping shall be retested.

i. Joints and connections of welded or screwed lines to be hydrostatically tested shall be painted with a blue powdered chalk and water mixture and allowed to dry before filling lines with water. Upon completion of testing, all chalk shall be removed from the piping that is to be painted.

j. Duration of test shall be at least 30 minutes with no visible leaks and without appreciable loss of pressure as determined by the Conmission except

k. Where the piping codes included herein require piping-systems to be flushed, the piping shall be flushed with clean water from existing supplies at a velocity of 10 feet per second. Flushing shall be continued until discharge water is as clean as the supply water.

\section{DISINFECTING SANITARY WATEER PIPING}

A11 sanitary water piping shall be disinfected in accordance with HW-4966-S, Standard Specification for Disinfecting Sanitary Water Supply Systems.

\section{SEALING PIPE SLEEVES}

Wherever pipe sleeves, occur, the annular space between the sleeve and the pipe (or between the sleeve and pipe insulation in the case of insulated lines) shall be packed with tarred jute to within $1 / 2$ inch of the ends of the sleeve. The $1 / 2$ inch deep space at the ends of the sleeve shall then be sealed with a Thiokol type sealing compound of the type specified in Section 18 herein. 
42. IDENRIITCAMTON OF PROCESS PIPING

2. Ail process lines which appear on drawing H-3-20488 with line numbers sheil save the number painted on the wall or floor where they emerge into the Pyroo Cell, Pipe Trench, Decontamination Stall, Mechanical Cell, cubicles and in Rooms No. 3 and No. 11 .

b. In the Waste Tank Vaults, line numbers shall be painted on the piping at intervais of 8 feet, as well as on the walls where the lines emerge.

c. Ijentifyirg numbers shall be $3 / 4^{\prime \prime}$ high, block characters painted in black Eloss snamel as specified in Division XVI, except that characters painted airectily on piping shall be of a size in keeping with the size of the pipe.

d. A continuity check shall be made on lines shown on drawing H-3-20488 by pessing compressed air or water through the line to verify that the correst ine number has been used at both ends of the line.

43. FRESSUES PIPIIG CONPLETION RECORD

a. "Pressure Piping Completion Record" form is attached to this specification ss Appendix C. Work on steam lines (denoted as MP and LP on the drawings), caustic (C) and nitric acid (A) lines shall be documented by the use of this form.

b. One or more Pressure Fiping Completion Record forms shall be used to describe 2nd record each of the piping systems specified in paragraph a. above. Under "Description of Piping" each piping system shali be described in enough letail and divided into encugh piping reaches to readily identify the procedure numer, filler material, welder's identification number, etc. used for any welo.

e. Mnese records shall be prepared and certified and signatures obtained by the Contractor prior to backfilling, insulating, embedding, or otherwise covering any part of the piping systems involved. Forms will be furnished by the Commission. The forms shall be completed and 5 signed copies submitied to the Commission. Satisfactory completion of these records is required prior to acceptsnce of any of the piping work concerned.

\section{ETPING CODES}

Al] Fiping materials, fabrication, installation, hydrostatic testing, and irsulation shall be in conformance with the drawings, these specifications snd the following Piping Codes: 


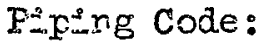

Service:

$\mathrm{H}-3$

Maximum Pressure:

Propane Gas, Low Pressure (PR)

Temperature Range:

50 psig

Atmospheric

\begin{tabular}{|c|c|c|c|}
\hline $8 \pm 268$ & I/2" OD and smaller** & 3/4" IPS and smaller & $I^{\prime \prime}$ and larger \\
\hline Pize & $\begin{array}{l}\text { Copper tubing ASTM BT5. } \\
\text { Annealed with flared } \\
\text { fittings; annealed or } \\
\text { hard with solder } \\
\text { fittings. }\end{array}$ & \multicolumn{2}{|c|}{$\begin{array}{l}\text { Schedule } 40 \text { black steel, any ASTM } 253 \text { or } \\
\text { Alo6 except acid bessemer }\end{array}$} \\
\hline Ittings & $\begin{array}{l}\text { Flared: cast, wrought, } \\
\text { or bar stock brass } 45^{\circ} \\
\text { SAE flare. } \\
\text { Solder: wrought copper }\end{array}$ & $\begin{array}{l}\text { Schedule } 40 \text { ( } 2000 \mathrm{Ib}) \\
\text { forged steel socket- } \\
\text { welding, ASA BI6.11 }\end{array}$ & $\begin{array}{l}\text { Schedule } 40 \\
\text { wrought steel } \\
\text { butt-welding, } \\
\text { ASA BI6.9 }\end{array}$ \\
\hline Waions & Flared couplings & $\begin{array}{l}\text { Schedule } 40(20001 \mathrm{~b}) \\
\text { forged steel socket- } \\
\text { welding, steel-tow } \\
\text { steel seat }\end{array}$ & Use flanges \\
\hline Fonges & None & $\begin{array}{l}150 \text { Ib forged steel } \\
\text { socket-welding AsA } \\
\text { B16.5. Use flat-face } \\
\text { where mating to flat } \\
\text { face flange. }\end{array}$ & $\begin{array}{l}150 \text { 1b. forgej } \\
\text { steel welding } \\
\text { neck ASA B.6.5 } \\
\text { Use flat-1ace } \\
\text { where mating } \\
\text { to flat-face } \\
\text { flange. }\end{array}$ \\
\hline Boiting & None & \multicolumn{2}{|c|}{$\begin{array}{l}\text { Carbon steel, heavy hexagon or reguiar } \\
\text { square bolts and heavy hexagon nuts, } \\
\text { ASTM A } 307 \text {, Grade B. }\end{array}$} \\
\hline fs,skets & \multicolumn{3}{|c|}{$\begin{array}{l}\text { 1/16" compressed asbestos sheet, not graphited; use full-face } \\
\text { gasket with flat-face flanges. }\end{array}$} \\
\hline $\begin{array}{l}\text { Peives } \\
\text { Ca"e } \\
\text { Giobe } \\
\text { Argie } \\
\text { Crieck } \\
\text { Eal! } \\
\text { Diarhragm- } \\
\text { Saunders }\end{array}$ & \multicolumn{2}{|l|}{$\begin{array}{l}\text { None } \\
\text { GL } 2 \text { S } 659 \\
\text { A. } 2 \text { S } 661 \\
\text { C } 2 \text { S } 657 \\
\text { B-S } 2021 \\
\text { D } 1.5 \text { S } 441\end{array}$} & $\mathrm{D} 1.5 \mathrm{~F} 327$ \\
\hline leening & \multicolumn{3}{|c|}{ Flush with water before testing } \\
\hline mesting & \multicolumn{3}{|c|}{$\begin{array}{l}\text { (1) Hydrostatic test at } 100 \text { psig (2) dry completely with compressei } \\
\text { ai ( } 3 \text { ) purge with propane using a flame arrester on the discharge } \\
\text { (4) fill with propane to operating pressure and test with soap } \\
\text { solution. }\end{array}$} \\
\hline
\end{tabular}

* System must meet requirements of NFPi 58 .

* For final connection to equipmenu only. 
Pipirg Code:

Serviee:

Argon (AR)

$\mathrm{H}-6$

Maximum Pressure: 150 psig

Texpersture Range: Atmospheric

\begin{tabular}{|c|c|c|c|}
\hline $59 z=8$ & $1 / 2^{\prime \prime}$ OD and smallex* & $3 / 4^{\prime \prime}$ IPS and smaller & $2^{\prime \prime} a_{1}=2 a=$ \\
\hline Pipe & $\begin{array}{l}\text { Seamless copper tubing } \\
\text { ASTM B75. Annealed with } \\
\text { flared fittings; annea- } \\
\text { led or hard with solder } \\
\text { fittings. }\end{array}$ & \multicolumn{2}{|c|}{$\begin{array}{l}\text { Schedule } 40 \text { black steel, any ASTM A53 or A.06 } \\
\text { except acid bessemer. }\end{array}$} \\
\hline Fìtijngs & $\begin{array}{l}\text { Flared: cast, wrought } \\
\text { or bax stock brass } 45^{\circ} \\
\text { SAE flare. Solder: } \\
\text { wrought copper }\end{array}$ & $\begin{array}{l}\text { Schedule } 40 \text { ( } 2000 \\
\text { Ib) forged steel } \\
\text { socket-welding } \\
\text { ASA BI6.II }\end{array}$ & $\begin{array}{l}\text { Schedule } 40 \text { wrought s\%e: } \\
\text { butt-welding ASA Bi6.9 }\end{array}$ \\
\hline tingons & Flared couplings & $\begin{array}{l}\text { Schedule } 40 \text { ( } 2000 \\
\text { Ib) forged steel } \\
\text { socket-welding, } \\
\text { steel to steel } \\
\text { seat }\end{array}$ & None \\
\hline Finnges & None & None & 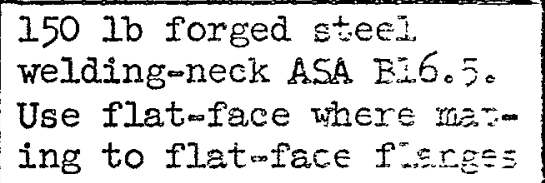 \\
\hline Bolting & None & None & 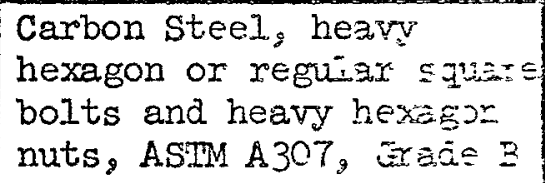 \\
\hline Ceskets & None & None & 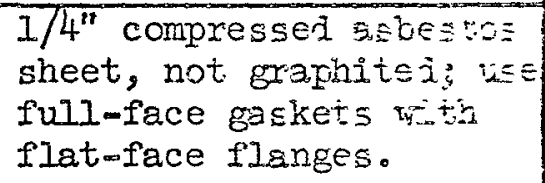 \\
\hline $\begin{array}{l}\text { Vaives } \\
\text { Cate } \\
\text { Globe } \\
\text { Angle } \\
\text { Check } \\
\text { Eain } \\
\text { IEsphragm } \\
\text { Sauniers }\end{array}$ & \multicolumn{2}{|l|}{$\begin{array}{l}\text { IPS Sizes } \\
\text { None } \\
\text { GL } 2 \text { S } 659 \\
\text { A } 2 \text { S } 661 \\
\text { C } 2 \text { S } 657 \\
\text { B-S } 2021 \\
\text { D } 1.5 \text { S } 442\end{array}$} & $\begin{array}{l}\text { None } \\
\text { GI } 1.2 \text { F } 3:= \\
\text { A } 1.2 \text { F } 3:= \\
\text { C } 1.2 \text { F } 3 E= \\
\text { D } 1.5 \text { F } 303\end{array}$ \\
\hline Giesning & \multicolumn{3}{|c|}{ Flush with water before testing } \\
\hline Tezting & \multicolumn{3}{|c|}{$\begin{array}{l}\text { (1) Hydrostatic test at } 225 \text { psig (2) dryout with compressed air }(3) \\
\text { purge with argon ( } 4 \text { ) fill with argon to operating pressure and test } \\
\text { with soap solution }\end{array}$} \\
\hline
\end{tabular}

For lise in making final connections to equipment. 
Fiping code:

Service:

Msximum Pressure:

Compressed AIr (CA)

B-8

Temperature Range: Atmospherlc

\begin{tabular}{|c|c|c|c|}
\hline SLzes & Less $\operatorname{than} 1 / 2^{\prime \prime} O D^{*}$ & $1 / 2^{\prime \prime}$ to $1-1 / 2^{\prime \prime}$ & $2^{\prime \prime}$ and larger \\
\hline Plpe & $\begin{array}{l}\text { Copper tubing, ASTM BT5. } \\
\text { Annealed with flared } \\
\text { flttings; annealed or } \\
\text { drawn with solder } \\
\text { fittings. }\end{array}$ & $\begin{array}{l}\text { Schedule } 40 \text { black } \\
\text { steel any ASTM A53 } \\
\text { or AI20 }\end{array}$ & $\begin{array}{l}\text { Schedule } 40 \text { black steel } \\
\text { any AstM A53 or Al06 } \\
\text { except acid bessemer. }\end{array}$ \\
\hline Mittings & $\begin{array}{l}\text { Flared: Cast, wrought } \\
\text { or bar stock brass, } \\
45^{\circ} \text { SAE flared. Solder- } \\
\text { ed: wrought copper }\end{array}$ & $\begin{array}{l}150 \text { Ib. malleablew } \\
\text { iron, screwed, ASA } \\
\text { B16.3 }\end{array}$ & $\begin{array}{l}\text { Schedule } 40 \text { wrought } \\
\text { steel butt-welding, ASA } \\
\text { B16.9 }\end{array}$ \\
\hline Uatons & Flared couplings & $\begin{array}{l}150 \text { ib malleable- } \\
\text { iron, screwed. } \\
\text { Brass-to-iron seat }\end{array}$ & Use flanges \\
\hline Flanges & None & . & $\begin{array}{l}\text { I50 Ib forged welding } \\
\text { neck ASA Bl6.5. Use llat. } \\
\text { face where mating to flat } \\
\text { face flanges }\end{array}$ \\
\hline Bolting & None & None & $\begin{array}{l}\text { Carbon steel, heavy } \\
\text { hexagon or regular squsre } \\
\text { bolts \& heavy hexagon } \\
\text { nuts, ASTM A307, Grade B }\end{array}$ \\
\hline Casisets & None & None & $\begin{array}{l}\text { I/I6" compressed asbestos } \\
\text { sheet, not graphited; } \\
\text { Use full-aface gaskets } \\
\text { with flat-face flanges }\end{array}$ \\
\hline $\begin{array}{l}\text { Talres } \\
\text { Cate } \\
\text { Globe } \\
\text { Angle } \\
\text { Cbeck } \\
\text { Bril }\end{array}$ & $\begin{array}{l}\text { IPS Sizes } \\
\text { G } 2 \text { S } 652 \\
\text { GL } 2 \text { S } 653 \\
\text { A } 2 \text { S } 655 \\
\text { C } 2 \text { S } 656 \\
\text { B-S } 2021\end{array}$ & & $\begin{array}{l}\text { G } 1.2 \text { F } 302 \\
\text { GL } 1.2 \text { F } 304 \\
\text { A } 1.2 \text { F } 305 \\
\text { C } 1.2 \text { F } 306 \\
\text { B.F } 2141\end{array}$ \\
\hline Clesuing & \multicolumn{3}{|c|}{ Flush with water before testing } \\
\hline Nesting & \multicolumn{3}{|c|}{ Hydrostatic test at $225 \mathrm{psig}$ and dry with compressed alm } \\
\hline
\end{tabular}


Pipling coàe:

service:

Maximum Pressure: 150 psig

Ierreverature Range: $300 \mathrm{~F}$
$\mathrm{H}-10$

Condensate (CNDS)

\begin{tabular}{|c|c|c|}
\hline Sizez & $1-1 / 2^{\prime \prime}$ and smaller & $2^{\prime \prime}$ and larger \\
\hline Pipe & \multicolumn{2}{|c|}{ Standard weight black wrought iron ASTM A72. } \\
\hline Fotings & $\begin{array}{l}150 \text { Ib malleable-iron screwed } \\
\text { ASA B16.3 }\end{array}$ & $\begin{array}{l}\text { Butt-welding ASA B16.9, material } \\
\text { and wall thickness to match pipe }\end{array}$ \\
\hline TnIons & $\begin{array}{l}150 \text { lo malieable-iron screwed } \\
\text { brass-to-iron seat }\end{array}$ & Use flanges \\
\hline Fenges & None & $\begin{array}{l}150 \text { Ib. steel welding-neck ASA } \\
\text { B16.5: Use flat-face where } \\
\text { mating to flatwface flanges. }\end{array}$ \\
\hline Eosting & None & $\begin{array}{l}\text { Carbon steel, heavy hexagon or } \\
\text { regular square bolts and heavy } \\
\text { hexagon nuts, ASTM A } 307 \text {, Grade B. }\end{array}$ \\
\hline Goskets & None & $\begin{array}{l}\text { 1/16" compressed asbestos sheet, } \\
\text { not graphited; Use full-face gasket. } \\
\text { with flat face flanges. }\end{array}$ \\
\hline $\begin{array}{l}\text { Yalves } \\
\text { Gate } \\
\text { G.oke } \\
\text { Angle } \\
\text { aneck }\end{array}$ & $\begin{array}{l}\text { G } 2 S 652 \\
\text { G. } 2 \text { S } 653 \\
\text { A } 2 \text { S } 655 \\
\text { C } 2 \text { S } 656\end{array}$ & $\begin{array}{l}\text { G } 1.2 \text { F } 302 \\
\text { GL } 1.2 \text { F } 304 \\
\text { A } 1.2 \text { F } 305 \\
\text { C } 1.2 \text { F } 306\end{array}$ \\
\hline Zessing & \multicolumn{2}{|c|}{ Hydrostatic test at $225 \mathrm{psig}$ and blow out with air. } \\
\hline cileaning & Flush with water: & \\
\hline
\end{tabular}


Ripirg Code:

sexvi:e:

Maxinum Pressure:

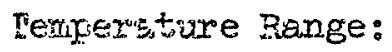

H-II

Vacuum Air Sampling (VAS)

Vacuum

Atmospheric

\begin{tabular}{|c|c|c|}
\hline Siges & $1-1 / 2^{\prime \prime}$ and smaller & $2^{\prime \prime}$ and larger \\
\hline Paipe & $\begin{array}{l}\text { Schedule } 40 \text { black steel, any } \\
\text { ASTM A53 or Al20 }\end{array}$ & $\begin{array}{l}\text { Schedule } 40 \text { black steel, any ASTM } \\
\text { A53 or Al06 except acid-bessemer. }\end{array}$ \\
\hline Fitzings & $\begin{array}{l}150 \text { Ib screwed malleable-iron } \\
\text { per ASA BI6.3. }\end{array}$ & $\begin{array}{l}\text { Schedule } 40 \text { steel butt welding per } \\
\text { ASA B16.9 }\end{array}$ \\
\hline Unioxs & $\begin{array}{l}150 \text { I3 malleable-iron screwed } \\
\text { brass-to-iron seat }\end{array}$ & Use flanges \\
\hline Flanges & None & $\begin{array}{l}150 \mathrm{lb} \text { forged steel welding neck, } \\
\text { ASA Bl6.5. Use flat face where } \\
\text { mating to flat-face flanges. }\end{array}$ \\
\hline Eolting & None & $\begin{array}{l}\text { Carbon steel, heavy hexagon or } \\
\text { regular square bolts, and heavy } \\
\text { hexagon nuts, ASTM A307, Grade B }\end{array}$ \\
\hline Caskets & None & $\begin{array}{l}\text { 1/16" medium hard neoprene ( } 60 \\
\text { durometer, } \pm 5 \text { ). Use fulloface } \\
\text { gaskets with flat-face flanges. }\end{array}$ \\
\hline 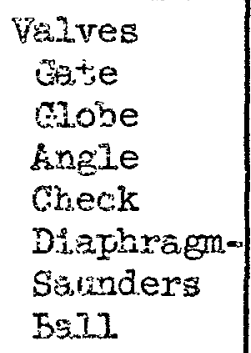 & $\begin{array}{l}\text { None } \\
\text { GL } 1.5 \mathrm{~S} 626 \\
\text { A } 1.5 \mathrm{~S} 627 \\
\text { None } \\
\text { D } 1.5 \mathrm{~S} 443 \\
\text { B-S } 2041\end{array}$ & $\begin{array}{l}\text { None } \\
\text { GL } 1.2 \mathrm{~F} 316 \\
\text { A } 1.2 \mathrm{~F} 320 \\
\text { None } \\
\text { D } 1.5 \mathrm{~F} 330 \\
\text { B-F } 2141\end{array}$ \\
\hline Festing & \multicolumn{2}{|c|}{$\begin{array}{l}\text { Fill with oil-free air or nitrogen to } 50 \text { psigs test with soap } \\
\text { solution. Blow out with eir un nitrogen. }\end{array}$} \\
\hline
\end{tabular}


Fiping Code:

Semrice:

Meximum Pressure:

Dexperature Range:
$\mathrm{H}-12$

Sanitary Water, Hot and Cold, Inside Building (SW) (HSW), Raw Water (RW), Instrument Air (IA) Ventilation Instrument Air (VIA), Process Water

150 psig

Up to $200 \mathrm{~F}$

\begin{tabular}{|c|c|c|c|}
\hline sizes & $I / 2^{\prime \prime}$ OD \& Smaller & $3^{\prime \prime}$ IPS \& Smaller & 4" IPS \& Larger \\
\hline$P-j e$ & $\begin{array}{l}\text { Copper tubing ASTM B75, } \\
\text { snnealed or aluminum } \\
\text { per ASTM B210, Type } \\
\text { 6061-T4 }\end{array}$ & $\begin{array}{l}\text { Galvanized steel, any } \\
\text { ASTM A53 or Al20 }\end{array}$ & $\begin{array}{l}\text { Black steel, any } \\
\text { ASTM A53 or Alob, } \\
\text { except acid- } \\
\text { bessemer. }\end{array}$ \\
\hline 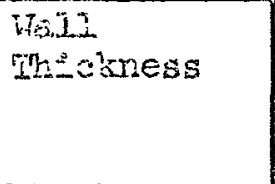 & 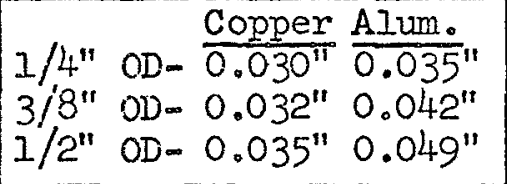 & Schedure 40 & Schedule 40 \\
\hline$F \div$ țings & $\begin{array}{l}\text { Flared: wrought or bar } \\
\text { stock brass, } 45^{\circ} \mathrm{SAE} \\
\text { flare. }\end{array}$ & $\begin{array}{l}\text { I50 Ib galvanized } \\
\text { malleable iron screwed } \\
\text { ASA BI6.3 }\end{array}$ & $\begin{array}{l}\text { Schedule } 40 \text { wrought, } \\
\text { steel, butt wejdins, } \\
\text { ASA BI6.9 }\end{array}$ \\
\hline Inions & Flared couplings & $\begin{array}{l}\text { I50 Ib galvanized } \\
\text { malleable iron } \\
\text { screwed, brass-to- } \\
\text { iron seat. }\end{array}$ & Use flanges \\
\hline \multirow[t]{2}{*}{ Plerges } & \multirow[t]{2}{*}{ None } & $\begin{array}{l}150 \text { Ib screwed steel } \\
\text { per ASA B16.5 where } \\
\text { shown on the drawings. }\end{array}$ & $\begin{array}{l}150 \text { Ib forged steel } \\
\text { welding neck or } 1 \pm \text { - } \\
\text { on ASA BI6.5. }\end{array}$ \\
\hline & & \multicolumn{2}{|c|}{$\begin{array}{l}\text { Use flat-face where mating to flat- } \\
\text { face flanges. }\end{array}$} \\
\hline Eoling & None & None & $\begin{array}{l}\text { Carbon steel, square } \\
\text { or hex head nuts } 20=\infty \\
\text { ASTM A307. }\end{array}$ \\
\hline Graxet: & None & None & $\begin{array}{l}\text { 1/16" compressed } \\
\text { asbestos sheet, not } \\
\text { graphited. Use full- } \\
\text { face gaskets witin fisto } \\
\text { face flanges. }\end{array}$ \\
\hline $\begin{array}{l}\text { Mages } \\
\text { Gotes } \\
\text { Globe } \\
\text { Arisle } \\
\text { Geok } \\
\text { Duli }\end{array}$ & \multicolumn{2}{|l|}{ 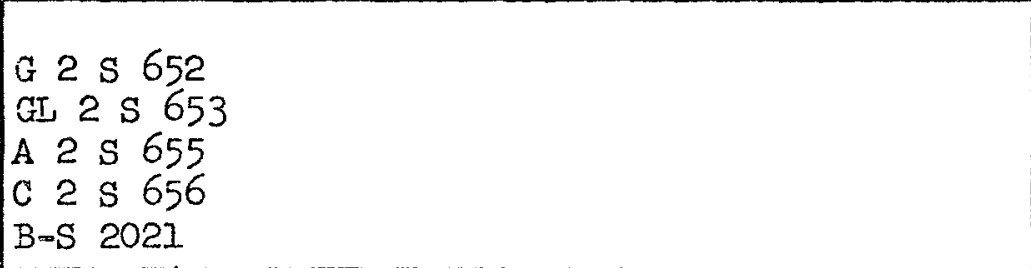 } & G $1.2 \mathrm{~F} 302$ \\
\hline gesting & \multicolumn{3}{|c|}{ Hyórostatic test at 225 psig } \\
\hline $\begin{array}{l}\because 23 i n f e c t i n g \\
\therefore 9=0 \text { aning }\end{array}$ & \multicolumn{3}{|c|}{$\begin{array}{l}\text { Sanitary water piping shall be disinfected in accordance with Harfori } \\
\text { Standard Specification HW-4966-S. FInsh vith veter. }\end{array}$} \\
\hline
\end{tabular}


Funing Code:

Sextise:

Maxirame Dressure:

Temperature Range:
$\mathrm{H}-14$

Steam, Low and Medium Pressure (LP) \& (MP)

125 psig

$350 \mathrm{~F}$

\begin{tabular}{|c|c|c|c|}
\hline Sizes & $i / 2^{\prime \prime}$ OD \& Smaller & $i-1 / 2^{\prime \prime}$ IPS \& Smaller & 2" IPS \& Iarger \\
\hline Fipe & $\begin{array}{l}\text { Copper tubing ASTM } \\
\text { BT5, annealed. }\end{array}$ & $\begin{array}{l}\text { Black steel, any ASTM } \\
\text { A53 or Al20. }\end{array}$ & $\begin{array}{l}\text { Seamless black steeI } \\
\text { any ASTM A53 or ÁU6 } \\
\text { except acid-besserex. }\end{array}$ \\
\hline $\begin{array}{l}\text { higli } \\
\text { Tinokness }\end{array}$ & $\begin{array}{l}1 / 4^{\prime \prime} \text { OD }-0.030^{\prime \prime} \\
3 / 8^{\prime \prime} \text { OD }-0.032^{\prime \prime} \\
1 / 2^{\prime \prime} \text { OD }-0.035^{\prime \prime}\end{array}$ & Schedule 40 & $\begin{array}{l}2^{\prime \prime} \operatorname{thru} 10^{\prime \prime}=\operatorname{sen} 0+0 \\
12^{\prime \prime} \text { thru } 2 \div "=0.375^{\prime \prime}\end{array}$ \\
\hline$F=$ țtings & $\begin{array}{l}\text { Flared: wrought or } \\
\text { ber stock brass, } 45^{\circ} \\
\text { SAE flare. }\end{array}$ & $\begin{array}{l}150 \text { Ib malleable iron, } \\
\text { screwed, ASA B16.3. }\end{array}$ & $\begin{array}{l}\text { Wrought steel bitio } \\
\text { welding* ASA BI6.9. } \\
\text { Wall thickness to } \\
\text { match pipe. }\end{array}$ \\
\hline Tnione & Fiared couplings & $\begin{array}{l}150 \text { Ib malleable iron } \\
\text { screwed, brass-to- } \\
\text { iron seat. }\end{array}$ & Use flanges \\
\hline Flanges & None & None & $\begin{array}{l}150 \text { Ib forged steel } \\
\text { welding neck ASA BI6.4. } \\
\text { Use flat-face where } \\
\text { mating to flat-face } \\
\text { flanges. }\end{array}$ \\
\hline Bojting & None & None & $\begin{array}{l}\text { Carbon steel, squire } \\
\text { or hex head boits } \\
\text { heavy hex nuts } \\
\text { ASTM A } 307 \text {. }\end{array}$ \\
\hline Carizets & None & None & $\begin{array}{l}\text { I/16" compressed } \\
\text { asbestos sheet. not } \\
\text { graphitedi tise fuli } \\
\text { face gaskets with } \\
\text { flat face flanges. }\end{array}$ \\
\hline $\begin{array}{l}\text { Vaves } \\
\text { Gate } \\
\text { Gione } \\
\text { Arye } \\
\text { Shecix } \\
\text { Bail }\end{array}$ & \multicolumn{2}{|l|}{$\begin{array}{l}G 2 S 652 \\
G=2 S 653 \\
A=S 655 \\
C 2 S 656 \\
B-S 2020\end{array}$} & $\begin{array}{l}\text { G } 1.2 \text { F } 302 \\
\text { GL } 1.2 \text { F } 304 \\
\text { A } 1.2 \text { F } 305 \\
\text { C } 1.2 \text { F } 306\end{array}$ \\
\hline $\begin{array}{l}\text { Exips \& } \\
\text { Etrainers }\end{array}$ & None & \multicolumn{2}{|c|}{ ST $1.2 \mathrm{~S} 1001 * \quad \mathrm{~T} 1.5 \mathrm{~S} 1500$} \\
\hline Sestang & \multirow{2}{*}{\multicolumn{3}{|c|}{ Hydrostatic test at 200 psig and steam test at operating temperature. }} \\
\hline Dentan & & & \\
\hline
\end{tabular}

* $3^{\prime \prime}$ mejeatle iron screwed fittings permitted at traps and heating coil connections. 
Finging Code:

Service:

Maxinum Pressure: 150 psig

Tencersture Range: Atmospheric
$\mathrm{H}-16$

Fire and Sanitary Water, Underground (F)

\begin{tabular}{|c|c|c|}
\hline S.zes & 2-1/2" \& Smaller & $3^{\prime \prime}$ thru $24^{\prime \prime}$ \\
\hline Fipe & $\begin{array}{l}\text { Schedule } 40 \text { galvanized steel, antr } \\
\text { ASTM A53 or Al20 }\end{array}$ & $\begin{array}{l}\text { Class } 150 \text { centrifugally cast iron, } \\
\text { ASA A21.6 or ASA A2l.8 with } \\
\text { mechanical joints per ASA Aal.1.j. } \\
\text { Alternate: Class } 150 \text { asbestoso } \\
\text { cement ASTM C296 with "Ring-Iite" } \\
\text { joints. }\end{array}$ \\
\hline Ftytings & $\begin{array}{l}\text { I50 lb galvanized malleable- } \\
\text { iron screwed, ASA BI6.3. }\end{array}$ & $\begin{array}{l}\text { To match pipe } \\
\text { Ring-Tite joints, TIFCO RR fittings } \\
\text { or approved equal, The Inderendent } \\
\text { Fittings Co., Portland, Oregon }\end{array}$ \\
\hline $\begin{array}{l}\text { Paizes } \\
\text { Gote }\end{array}$ & $\frac{1-1 / 2^{\prime \prime} \text { and smaller }}{G 1.5 \mathrm{~S} 628}$ & $\begin{array}{l}\text { For use with indicator post, } \\
\text { G } 1.2 \mathrm{M} 504 \text {. Regular type, } \\
\text { G } 1.2 \mathrm{M} 503 \text {. }\end{array}$ \\
\hline $\begin{array}{l}\text { VaIte } \\
\text { Accessories }\end{array}$ & \multicolumn{2}{|c|}{$\begin{array}{l}\text { Extension Enclosure: Cast-iron service box, roadway box or valve box. } \\
\text { Indicator Post: IP } 1.2 \text { F } 512\end{array}$} \\
\hline $\begin{array}{l}\text { Fise } \\
\text { Bydrant }\end{array}$ & INone & $\begin{array}{l}\text { Fire hydrant installation ir con- } \\
\text { formance with Hanford Standard } \\
\text { M-2-22. }\end{array}$ \\
\hline Jesting & \multicolumn{2}{|l|}{ Hyärostatic test at 200 psig. } \\
\hline $\begin{array}{l}D_{-\infty}^{2} \text { sudecting } \\
\text { 3. cleanirg }\end{array}$ & \multicolumn{2}{|c|}{$\begin{array}{l}\text { Fire and sanitary water piping shall be disinfected in accordance with } \\
\text { Hanford Standard Specification HW-4966-S. Filish vith wiser. }\end{array}$} \\
\hline
\end{tabular}


Piping Code: Eerrice: Maximum Pressure: Pemperature Range:
$\mathrm{H}-18$

Sanitary Sewer, Waste and Vent - Inside Buildings Lines (SNS) Gravity Flow

Varies

\begin{tabular}{|c|c|c|}
\hline Sizes & Aboveground: $2-1 / 2 "$ \& smaller & $\begin{array}{l}\text { Aboveground: } 3^{\prime \prime} \text { \& larger } \\
\text { Underground: AIl sizes }\end{array}$ \\
\hline Pape & $\begin{array}{l}\text { Schedule } 40 \text { galvanized steel, } \\
\text { any ASTM A53 or Alzo. }\end{array}$ & $\begin{array}{l}\text { Extra-heavy cast-iron soil pipe } \\
\text { ASA A40.1. }\end{array}$ \\
\hline Bnione & $\begin{array}{l}150 \text { Ib gaivanized malleable- } \\
\text { iron screwed }\end{array}$ & None \\
\hline Toints & Screwed & $\begin{array}{l}\text { Firmly packed with tarred jute, } \\
\text { filled with molten lead not less } \\
\text { than one inch deep and caulked. } \\
\text { sufficient lead shall be used so } \\
\text { that when caulking is completed, } \\
\text { the lead shall not extend more } \\
\text { than } 1 / 8 \text { " below the rim of the huc. }\end{array}$ \\
\hline Fittings & $\begin{array}{l}\text { Waste Iines: Cast-iron screwed } \\
\text { drainage, ASA BI6.I2 } \\
\text { Vent Iines: } 150 \text { Ib galvanized } \\
\text { malleable iron screwed, } \\
\text { ASA BI6.3; or } 125 \text { 1b cast- } \\
\text { iron screwed, ASA B16.4 }\end{array}$ & $\begin{array}{l}\text { Extra-heavy cast-iron soil } \\
\text { fittings, ASA A } 40.1\end{array}$ \\
\hline Testing & \multicolumn{2}{|c|}{ Hydrostatic gravity test conforming to Paragraph 14.9.1 of ASA A40.8. } \\
\hline
\end{tabular}


Fiping code:

service:

Meximum Pressure:

Tempersture Range:
H-19

Sanitary Sewer, Underground - Outside of Bulldings (SNS) Gravity Flow

Varies

\begin{tabular}{|l|l|}
\hline Sizes & 4" thru 24" \\
\hline $\begin{array}{l}\text { Fipe and } \\
\text { Ff fings }\end{array}$ & $\begin{array}{l}\text { Extra strength vitrified clay, ASTM C278, with resilient jointing } \\
\text { connections conforming to ASTM C425, such as Gladding, McBean \& } \\
\text { Company "Speed-Seal". }\end{array}$ \\
\hline Iesting & $\begin{array}{l}\text { Hydrostatic gravity test subjecting each joint to not less than } \\
\text { a } 10 \text { foot head of water. }\end{array}$ \\
\hline
\end{tabular}


Piping Code:

Serrice:

Mexintum Pressure:

Fempersture Range:
$\mathrm{H}-19$

Chemical Sewer, Underground - Outside of Buildings (CPS, RFS) Gravity Flow

Varies

\begin{tabular}{|l|l|}
\hline Sizes & 4" thru 24" \\
\hline Pipe and & $\begin{array}{l}\text { Extra strength vitrified clay, ASTM C278 resilient jointing } \\
\text { connections conforming to ASTM C425, such as Gladding, McBean \& } \\
\text { Company "Speed-Seal". }\end{array}$ \\
\hline Testing & $\begin{array}{l}\text { Hydrostatic gravity test subjecting each joint to not less than } \\
\text { a } 10 \text { foot head of water. }\end{array}$ \\
\hline
\end{tabular}


Paping Code:

sem $; c e:$

Mextix Pressure:

weinjergture Range:
$\mathrm{H}-22$

Nitric Acid (A), Crib Waste Sewer (CBWS)**, Vacuum (V), Caustic (C)

100 psig

160 F maximum

\begin{tabular}{|c|c|}
\hline SEe & 1-1/2" \& Smaller \\
\hline Pipe & \begin{tabular}{l|l} 
Schedule 40S & Schedule IOS \\
Stainless steel, HWS-8064-S, Type 304I
\end{tabular} \\
\hline Fititings & $\begin{array}{l}\text { Stainless steel butt welding, HWS- } 8066 \text {-S, Type } 304 \mathrm{I} \text {, Schedule to } \\
\text { match pipe. Schedule } 40 \text { S screwed fittings, Cooper Alloy, or approved } \\
\text { equal, where shown on the drawings only. }\end{array}$ \\
\hline$F: \operatorname{singes} *$ & $\begin{array}{l}150 \text { Ib forged stainless steel welding-neck, HWS- } 8066-5 \text {, Type } 304 I_{7} \\
\text { bore to match pipe. Use flat-face where mating to flat-face flanges. }\end{array}$ \\
\hline $801+i \times g$ & $\begin{array}{l}\text { Stainless steel; stud bolts; ASTM Al93 Grade B8. Alloy steel nuts: } \\
\text { ASTM AI94, Grade } 8 \text { or } 8 \mathrm{~F}\end{array}$ \\
\hline Cosuts & $\begin{array}{l}\text { 1/16" Teflon sheet; use full-face gaskets where mating to flat-oface } \\
\text { flanges. }\end{array}$ \\
\hline 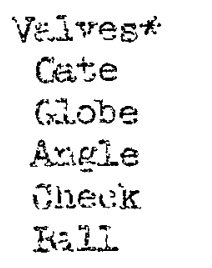 & $\begin{array}{l}G 1.5 \mathrm{~F} 801 \\
G 1.5 \mathrm{~F} 804 \\
\mathrm{~A} 1.5 \mathrm{~F} 811 \\
\mathrm{C} 1.5 \mathrm{~F} 808 \\
\mathrm{~B}-\mathrm{F} 2155\end{array}$ \\
\hline $\begin{array}{l}\text { Festing is } \\
\text { Gosning }\end{array}$ & $\begin{array}{l}\text { Fydrostatic test at } 150 \text { psig and ary out with oil-free air or } \\
\text { nitrogen after fiushing with water. }\end{array}$ \\
\hline
\end{tabular}

* Taives and flenges in asid (A) and caustic (C) lines shall be fitted with flange gis 3 s per Hanford Standard M-2-15.

* sinjess steel lines exposed to earth backfill shall be covered with a spiral ming of polyethylene tape lapping turns $1^{\prime \prime}$. 
Pipirg code:

Sexpice:

Mstrimes Fressure:

reupersture Range:
H-23

Demineralized or Distilled Water (DW)

100 psig

Up to $200 \mathrm{~F}$

\begin{tabular}{|c|c|}
\hline Sปz:s & A.1工 \\
\hline Ifpe & Schedule 4OS, stainless steel, ASTM A312 Grade TP 304 \\
\hline Fițtinge & $\begin{array}{l}\text { Schedule } 40 \mathrm{~S} \text {, wrought stainless steel butt-welding, ASTM A403 Grade } \\
\text { WP } 304\end{array}$ \\
\hline Flanges & $\begin{array}{l}150 \text { lo forged stainless steel welding-neck, ASTM AI82, Grade F } 304 \\
\text { bore to match pipe. Use flat-face flanges where mating to flat- } \\
\text { face flanges. }\end{array}$ \\
\hline Zoitung & $\begin{array}{l}\text { Stainless steel; stud bolts; ASTM A193, Grade B8. } \\
\text { Alloy steel nuts; ASTM AI94, Grade } 8 \text { or } 8 \mathrm{~F} \text {. }\end{array}$ \\
\hline Sôtakets & $\begin{array}{l}\text { 1/16" white compressed asbestos sheet, not graphited or medium hard } \\
\text { neoprene. Use full-face gaskets with flat-face flanges. }\end{array}$ \\
\hline 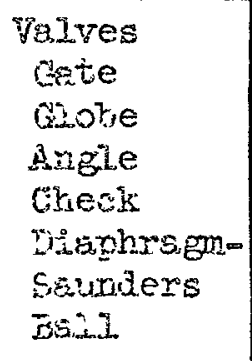 & $\begin{array}{l}G 1.5 \mathrm{~F} 801 \\
G 1.5 \mathrm{~F} 804 \\
\mathrm{~A} 1.5 \mathrm{~F} 811 \\
\mathrm{C} 1.5 \mathrm{~F} 808 \\
\mathrm{D} 1.5 \mathrm{~F} 833 \\
\mathrm{~B}-\mathrm{F} 2155\end{array}$ \\
\hline mesoing & $\begin{array}{l}\text { Hydrostatic test at } 150 \mathrm{psig} \text { and dry out with oil-free air or } \\
\text { nitrogen }\end{array}$ \\
\hline 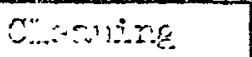 & Finsh with water prior to hycarostatic test. \\
\hline
\end{tabular}


Exping code:

Serrece:

Ys.ximum Eres sure:

Tempexiture Range:
$\mathrm{H} \approx 31$

Chilled Water, 34\% Ethylene Glycol solution (CW)

150 psig

$30=170 \mathrm{~F}$

\begin{tabular}{|c|c|c|}
\hline SIzES & $3 / 4^{\prime \prime} \&$ Smaller & I" \& Larger \\
\hline Pipe & \multicolumn{2}{|c|}{ Schedule 40 steel, any ASTM A53 ox Al06 except acidmbessemer } \\
\hline Eituringe & $\begin{array}{l}\text { Schedule } 40 \text { (2000 Ib) forged } \\
\text { steel socket-welding, ASA } \\
\text { B16.11 }\end{array}$ & $\begin{array}{l}\text { Schedule } 40 \text { wrought steel } \\
\text { butt-welding, ASA B16.9 }\end{array}$ \\
\hline Trione & $\begin{array}{l}\text { Schedule } 40 \text { ( } 2000 \mathrm{lb} \text { ) forged } \\
\text { steel socketwwelding, steel- } \\
\text { towsteel seat. }\end{array}$ & Use flanges \\
\hline Tange: & $\begin{array}{l}150 \text { ib forged steel socket } \\
\text { welding, ASA B16.5. Use flat- } \\
\text { face where mating to flat-iace } \\
\text { flanges. }\end{array}$ & $\begin{array}{l}150 \text { Ib forged steel welding } \\
\text { neck ASA BI6.5. Use flat-face } \\
\text { where mating to flat face flanges. }\end{array}$ \\
\hline Bolting & \multicolumn{2}{|c|}{$\begin{array}{l}\text { Carbon steel, heavy hexsgon or regular square bolts and heavy } \\
\text { hexagon nuts, ASTM A307, Grade B. }\end{array}$} \\
\hline Gaskets & \multicolumn{2}{|c|}{$\begin{array}{l}\text { 1/16" compressed asbestos sheet, not graphited, or medium hard } \\
\text { neoprene }(60 \text { duro } \pm 5) \text {; use fulloface gaskets with flat face } \\
\text { flanges. }\end{array}$} \\
\hline 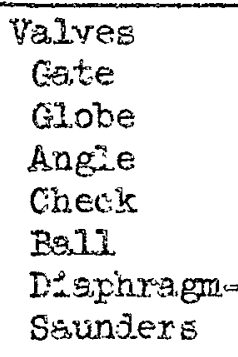 & $\begin{array}{l}\text { l-I/2" and Under } \\
6 T 276 \\
\text { G } 6 \mathrm{~T} 277 \\
\text { A } 6 \mathrm{~T} 278 \\
\text { C } 6 \text { T } 279 \\
\text { B-T } 2341 \\
\text { D } 1.5 \text { F } 328\end{array}$ & $\begin{array}{l}2^{\prime \prime} \text { and Larger } \\
\text { G } 1.2 \mathrm{~F} 302 \\
\text { GL } 1.2 \mathrm{~F} 304 \\
\mathrm{~A} 1.2 \mathrm{~F} 305 \\
\mathrm{C} 1.2 \mathrm{~F} 306 \\
\text { None }\end{array}$ \\
\hline TeEting & \multicolumn{2}{|c|}{ Hydrostatic test at $225 \mathrm{psig}$ and blow out with compressed air. } \\
\hline$\left(2 . \sin 3 . r_{1} g\right.$ & \multicolumn{2}{|l|}{ Fiusid with rater. } \\
\hline
\end{tabular}




\section{DIVISION VII}

ROOF DECKS AND ROOFING

GENERAI.

1. SOOFE

Thz: division covers roof decking, insulating concrete, preformed insilation and gravel surfaced built-up roofing for the Fuels Recycle Pilot Plant, Building 324. The combination of all roof components, exclusive of loading dock roof, shall have an overall coefficient of hest transmission not greater than $U=0.13 \mathrm{Btu}$.

2. REFERENGED STANDAFDS AND SFECIFICATIONS

The standards and specifications listed below form a part of this specification to the extent indicated by subsequent references.

2.1 AMERICSN SOCIEIY FOR TESTING AND MATERIAL

ASTM C332-56T Iight Weight Aggregates for Insulating Concrete ASTM C208-60 Structural Irsulating Board Made From Vegetable Fibers A.STM C150-61 Portland Cement

2.2 FTUEKAI SPECIFICATIONS

HF-I-52lc Mineral Wool Building Insulation, Batts, Ioose Fill and Granular Fill

HH-I-5e6a Thermal Accoustical, Mineral Wool Insulation Board (for roofs)

2.3 HANFOED STANDARD SPECIFICATIONS

HWS-6142-S Applying Insulation to Concrete Roof Decks

IWS-6143-S Applying Insulation to Steel Roof Decks

HWS-6149-S Built-Up Smooth and Gravel Surfaced Asphalt Roofs

on Insulated Decks

\section{MATERTALS}

3. METAY DECKING

3.1. MAIN BUTIDING

a. Metsl roof decking for the principal part of the building shall be 


\subsection{MAIN RYIIDING}

s. (Nontinued)

corrugated (or fluted) zinc-coated steel, formed from structural guility sheets. Corrugations shall not be greater than $1-1 / 2$ inches in defth. The decking shall be capable of supporting a combined live and dead load of 45 psf with a deflection of not more than $1 / 240$ of the span.

B. Decking panels shall be furnished in lengths to cover a minimum of two spans of roof support framing allowing a minimum of 2 inches bearing on end supports.

c. Decking shail be furnished with vent clips or perforations to provide ventilation for the insulating concrete (minimum of 2 per span).

d. Decking shall be furnished with 16 gauge anchor type, welding washers with a hole in the bearing surface to provide for plug welding the decking panels to the structural steel support framing.

\subsection{LOADING DOOK AND BUIIDING 324هA}

a. Metal roof decking for the loading dock and Building 324-A shall be deep fluted ( 4 w $/ 2$ inch) zinc coated steel formed from structural cuality sheets. The decking shall be capable of supporting a combined live and dead load of $40 \mathrm{psf}$ with not more deflection than 1/240 of the span for a simple span. Deck panels shall not be slit for venting.

b. Deeking shall be furnished with flat welding washers with a hole to provide for plug welding the panels to the structural steel supports.

c. Ierking shall be furnished with precaulked lip on one longitudinal edge of kanels. Vent clips are not required.

i. ROOF INSUTATION

Q. Rigid insulation for application on top of roof decks shall conform to the requirements of ASTM C208, Class C.

b. Irose fill insulation for Building $324-A$ roof shall conform to the requirements of Federal Specification HH-I-52lc, Type II.

5. INBUYATING CONCRETE

a. Aggregates for insulating concrete roof decks shall be an expanded vermicuiite conforming to ASTM 0332 , Group $I$. The unit weight of the eggregate shall be not less than $6 \mathrm{lb}$. or more than $10 \mathrm{lb}$. per cubice foot. Vermiculite aggregate shall be chemically treated to reduce capillaxity in the concrete. 
5. INSYLATING CONCRETE (Continued)

b. Cement for insulating concrete shall conform to the requirements of ASTM CI50, Type I or II.

\section{EOOFNNG MATERTALS}

Roofing materials for all roofs shall conform to the requirements of Hanfora Standard Specification HWS-6149-S. References to reflective roof costings, glass fiber roofing sheets and special heavy roofing sheets shall be disregarded.

\section{WORKMANSHIP}

7. INGTAIEATION OF STEEI ROOF DECKS

\subsection{MAIN EUIIDING}

a. All steel roof decking shall be attached to the supporting structure by rlug weliding. Wing type anchor washers shall be used, at spacings as specified in the decking manufacturer's installation instructions.

b. Decking shall be laid across the shorter spans of roof framing and sholl span a minimum of 2 spans per length of deck panel.

c. If decking is in solid sheets, vent clips shall be used at longitudinal laps; a minimum of 2 clips per span. If deck is punch or slitwented, vent clips will not be required.

d. Weld areas shall be cleaned, as soon as they have cooled, to remove weid spatter, slag and burned coatings. Weld areas shall then be touched up with zinc chromate primer of the type specified in Division XVI.

\subsection{TADTNG DOCK AND BUIIDING 324-A}

a. All steel roof decking shall be attached to the supporting structure by plug welding through welding washers. Spacing of welds shall be as recommended by the manufacturer of the decking.

b. Only fullospan length panels shall be used. End laps will not be perriztéả.

c. Side lexs of panels shall be fitted together carefully to preserve the effectiveness of the caulking and shall be mechanically fastened on 36 inch centers.

d. Weli areas shall be cleaned, as soon as they have cooled, to remove weld spstter, slag and burned costings. Weld areas shall then be touchedup with one coat of zine chromate primer of the type specified in Division XVI. 
8. MIXING AND PLACING INSUTATING CONCRETE

a. Insulating concrete shall be mixed in a fixed-blade, rotating drum mixer or plaster mixer with full drum agitator.

b. Mix design for insulating concrete shall be based on 1 part portland cement per 6 parts expanded vermiculite aggregate. Water added shall be sufficient to provide a slump of 6 to 7 inches and an oven dry Jensity of $30 \mathrm{lb}$. per cubic foot. The mix shall produce a uniform concrete with a compressive strength of 200 psi at 28 days.

c. Mixing time shall be limited to that required to wet all the cement and s.ggregetes and to form a uniform plastic mass. In no case shall the mixing time be more than 2 minutes. If transit mix equipment is used to deliver the concrete the mixer orum shall not be rotated while the equipment is in transit.

d. Insulating concrete shall be piaced immediately after mixing is complete. Screeds shall be set to provide the depth of concrete specified on the draxings. Insulating concrete shall be placed in alternate areas or psonels defined by the screeds. When one panel has been screeded smooth the traffic in adjacent panels shall be restricted until the concrete in the completed panel has set 12 hours. Insulating concrete shall be screeded smooth but shall not be trowel finished.

e. Insulating concrete shall not be placed on frosty surfaces or when the temperature is below $40 \mathrm{~F}$. When it is anticipated that the air temperature will be near or below $40 \mathrm{~F}$ after placing insulating concrete the mixing water shall be heated to $75 \mathrm{~F}$ to $100 \mathrm{~F}$.

f. The Contractor shall take all precautions necessary to protect insulating concrete from freezing for a period of 7 days after placement. If unsvoidable damage should occur from freezing, all loose and scaling conerete shall be removed and replaced.

g. The surface of the fresh insulating concrete shall be kept moist for a minimm of 3 days after placement, curing shall begin as soon as the concrete has taken an initial set. The insulating concrete shall be water cured; or an asphalt emulsion curing compound, which is compatible With roofing asphalt, shall be used. Compounds containing wax or ingredients which would prevent adhesion of roof insulation will not be aceptabie.

h. The insulating concrete shall be allowed to dry for a period of 21 dxys after curing is complete before application of roof insulation is sterted.

9. INSTAIIAATION OF ROOF INSUTATION

a. Applicstion of roof insulation on concrete decks shall conform to the revuirements of Hanford Standard Specification HWS-6142-S. 
9. INSTATIATION OF ROOF INSULATION (Continued)

b. Application of roof insulation on the loading dock roof and Building 324. A roof shall conform to the requirements of Hanford standard Specification HWS-6143-S.

c. Closures for metal decking flutes at the wall line at the front and back of Building 324-A shall be formed from 2 pieces of roof insulation cemented together and to the decking with hot asphalt or a heavy bodied asphalt mastic.

d. Ioose fili insulation shall be packed in the decking flute which occurs at the wall line at the sides of the Building 324-A to a density of 3 to $4 \mathrm{Ib}$. per cubic foot.

10. APPIENATION OF ROOFTNG

All. roofs shall be 4 ply felt, gravel surfaced asphalt roofs conforming to the requirements of Hanford Standard Specification HWS-6149-S. 


\section{DIVISION VIII}

PIASTER AND STUCCO WORK

AND SUSPENDED METAI-PAN CEIIIING

\section{GENERAI}

1. $\quad S O O P E$

This division of the specification covers all plastered walls and ceilings, Evspended ceilings and stucco work. for the Fuels Recycle Pilot Plant, BId8. 324.

2. SUENTSSION OF DRAWINGS

The Gontractor shall prepare drawings to show methods of fastening plaster partitions to floors and cellings and fastening suspended ceiling anchorages and aviforts, and present them to the Commission for approval prior to purchase of matersals. The drawings shall give complete information necessary for Instelletion of all components, including weights and sizes of all parts and methol of fastening partition framing to suspended ceilings.

3. FEIEEERTED STANDARDS AND SPECIFICATIONS

The standards and specifications listed below form a part of this specification to the extent indicated by references thereto.

3.1 AMERICAN SOCIETY FOR TESTING AND MATERIAIS (ASTM)

BSTM 628-60 Gypsum Plasters

ASIM C35-59 Inorganic Aggregates For Use In Gypsum Plaster

ASIM C150-6I Portland Cement.

3.2 ACYOUETTCAL MATERTALS ASSOCIATION (AMA)

AMA 1-11-59 Tests for Accoustical Materials

3.3 FEDERAI SPECIFICATIONS

HH-I-52lc Insulation, Building, Mineral Wool, Batts, Loose-Fill and Granular Fill

QQ-B-101c(1) Bases, Metal, (for) Plaster and Stucco Construction

SS.I-351 Iime, Hydrated, (for) Structural Purposes

Wr-Fultho Paper; Building, Waterproofed 


\section{MATERIAIS}

\section{PAKTIITON FRAMING}

a. Framing for 2 inch solid metal lath and plaster partitions shall consist of the following:

(1) Channel section studs, 3/4 inch cold rolled steel, shop costed, welghing $300 \mathrm{lb}$. per 1000 Irin. Ft. (Minimum).

(2) Metal 1ath, I/8 inch flatrib, 2.75 lb. per sq. yd., copper alloy steeI, shop painted with rust inhibitive paint. Iath shall be expanded metal type, conforming to Federal Specification QQ-Bolole, Type FR. Iath shall be tagged with metal tags bearing manufacturex's narae snd weight of lath.

(3) Rase assembly shall be 18 uss gauge galvenized steel and shall consist of:

(a) Floor clip, for mounting $3 / 4$ inch steel studs, and bracket arms for 3 inch snapmon base.

(b) Snap-on base, 3 inch, galvanized and prime painted, weighing 630 1b. per 1000 feet. Base splice plates shall be furnished.

(c) Cove base mould shall be 18 gauge galvanized and prime coatex steel, $1-3 / 16$ inches high, with sheet metal screws for attachment to metal base and wood screws for attachment to wood nailing strip. Inland Steel Co. "Milcor" No. 630 Cove Mould is an example of a product meeting these requirements.

(4) Ceiling runner shall be 20 gauge gslvanized steel channel section with integral clips for mounting $3 / 4$ inch steel studs. Ceiling zunner shall weigh not less than $200 \mathrm{Ib}$. per 1000 lineal feet.

(5) Corner bead shall be 26 gauge galvanized, short radius bead with 2-1/2 inch expanded metal wings snd weighing not less than $215 \mathrm{lb}$. per 1000 lineal feet. Casing bead is described in section 5e. below.

(6) Bracing at doors and vent duct openings with $3 / 4$ " steel channels.

(7) Tie wire for framing connections and splices shall be 16 gauge galvanized annealed, iron wire. Isth tie wire shall be the same except 18 gauge.

(8) Access doors for north wall of Entry ( $\mathrm{Rm}$. 103) shall be sheet metal doors and frames with expanded metal casing bead attached all around frames. Doors shall hove 3 spring loaded hinges and $a$ minimum of 4 screwdriver operated cam locks ( 1 each top and bottom 
4. FARTITICN FRAMING

a.

(8) Continued

and 2 on side opposite hinges). Doors and frames shall be factory prime coated. Access doors shall be Irland Steel Co. "Milcor" . Style K, or approved equal.

‡. Framing for $7-1 / 2$ inch metal lath and plaster partitions shall consist of the following:

(1) Channel section studs, 18 gauge galvanized steel, 6 inches wide.

(2) Floor runner (stud track), 6 inch channel section, 18 gauge galvanized steel, with stud shoes. Same construction at top and bottom of wall.

(3) Snap-on base, 3 inch, shop coated (same as in $4 a .(3)(b)$ above. Base ciip shall be the type that clips on rlange of stud and provides $3 / 4$ inch plaster ground and bracket arms for snap-on base.

(L) Iath, wire, cove mould and base shall be same as in a. above。

c. Framing for 5-1/2 inch metal lath and plaster partitions shall be same as in $b$. above except studs and track shall be 4 inches wide.

a. Framing for furred plaster partitions at pipe spaces shall be same as for 2 inch solid partitions except finished on only one side.

e. Intermediate framing for plaster and stucco panels shall consist of the foliowing:

(1) Nasiable steel studs, 3-1/4 inches wide, shop coated, and weighing not less than 670 Ib. per 1000 lineal feet.

(2) Stud track designed to fit over the flanges of the nailable studs specified in (I) above, and weighing not less than 430 lb. per 1000 lineal feet.

(3) Brackets, 3" snap-on base and cove mould for interior side of the wall shall be the same as specified in $4 \mathrm{a}(3)$ above.except where bastborid hesters occur.

(4) Metal lath shall be the same as specified in $4 a(2)$ above.

(5) Paper-backed wire reinforeing for exterior (stucco) side of the wall shall be as specified in $9 b$ herein. 
5. FRAMING FOR PIASTER CEIIINGS

8. Main channels for suspended plaster ceilings shall be $1-1 / 2$ inches $x$ $19 / 32$ inches $x 16$ ga. cold-rolled steel, either shop coated or galvenized and weighing not less than 490 lb. per 1000 lineal feet.

b. Gross channels shall be the same as a. above except $3 / 4$ inch $\times 1 / 2$ insh, weighing 300 Ib. per 1000 lineal feet.

5. Exransion joint for plaster and stucco surfaces shall be No. 15, 3/4 inch, zine, with expanded metal flanges.

d. Wre for suspending plaster ceiling framing shall be No. 9 gauge, gaivanized iron wire. Wire for framing connections and splices shail be 16 gauge, galvanized, annealed iron wire. Wire for lath ties shall ise the same except 18 gauge.

e. Casing beed for grounds and edging shall be $3 / 4$ inch square nose bead with expsnsion flange formed from 24 gauge galvanized steel and weighing not less than 280 Ib. per 1000 lineal feet.

\section{FEASTER}

*. Gxsum cement plaster for base coats shall be gypsum neat plaster conforming to ASTM C28. The material when mixed with two parts by weight of ottawa sand shall develop a compressive strength of not less than 750 psi in 7 days. US Gypsum "Redtop" cement plaster is an example of a material meeting these requirements.

b. Finish plaster shall be a hard galiging gypsum-cement type that will set in 40 min. and will develop a compressive strength of 1200 psi in 7 days. Finish plaster shall conform to ASTM C28. US Gypsum "Structo-Gauge" is an example of a material meeting these requirements.

7. IIME

Iime for preparation of lime putty to be used in plaster mixes shall be double hydrated lime conforming to Federal Specification SS-Im351, Type F.

8. SAND

Ssnd for plaster and stucco shall be natural or manufactured sand conforming t.o the requirements of ASIM C35. Sand shall be washed and cleaned and shall be uniformiy graded from coarse to fine within the following limits, by weight:

Retaried on Sieve No.

$\begin{array}{rl}4 & \text { None } \\ 8 & 0 \text { to } 5 \% \\ 16 & 5 \text { to } 30 \% \\ 30 & 30 \text { to } 65 \% \\ 50 & 65 \text { to } 95 \% \\ 100 & 90 \text { to } 100 \%\end{array}$


8. SAND (Continued)

sand for cellings in Entry and Lobby shall be white sand.

9. REINTORCINE FOR PIASTER AND STUCCO

s. Wire mesh for reinforcing plaster applied to concrete block walls shall be 18 gauge, galvanized, cold worked steel wire, woven or welded, medium ofenings. The wire shall be-crimped at increments of 3 inches. The wire mesh shall conform to the requirements of Federal Specification QQ-B-101cs Irpe SF. Keystone Steel \& Wire Co. self-furring "Keymesh" is an example of a product meeting the requirements stated immediately above.

b. Wire mesh for reinforeing stucco shall be woven, galvanized steel wire, with large hexagonal or rectangular mesh, not less than 17 gauge. Mesh shall conform to FederaI Specification QQ-B-IOIc, Type SF-B, except a papex backing shall be waterproof and shall conform to Federal Specification WU-P-I4Tb, Iype I, Class B. K-Iath Corp. "K-Lath", Style AK-98 I/S is an example of a wire mesh meeting the requirements stated immediately sbove.

.10. STU0CO

a. Cement for stucco, both base (scratch) coat and finish coat, shall conform to the requirements of ASTM CI50.

b. Ssid for stucco shall conform to the requirements of ASTM C35.

s. I.ime for stucco shall conform to the requirements of Federal Specification SS $-\mathrm{L}-35 \mathrm{~s}$.

d. Surface aggregate shall be white stone chips washed clean by wet processing.

11. WAIII INSUEATION

Insulation for plastered exterior walls shall be shotwree, glass fiber materisil in an enclosed-batt form with nailer tabs at the edges. Batts shal? have $A$ vapor barrier membrane on the principal face and shall be 2 inches in nominal thickness. Insulation shall conform to the requirements of Federal Specification $\mathrm{HH}-\mathrm{I}-52 \mathrm{Cl}$.

12. SISEFINLED ACOUSTICAL CEIIINGS (MEIAI PAN)

2. Ceiling panels shall be steel and shall be 23-5/8" wide $\times 47-5 / 8$ " $\times 1$ " thick of $.010^{\prime \prime}$ minimum thick steel perforated front and solid $.010^{\prime \prime}$ steel beck.

b. Perforeted hole pattern shall be $1 / 16^{\prime \prime}$ D. $\times 1 / 4^{\prime \prime}$ O.C. $45^{\circ}$ diagonal pattern. Faint finish shall be a non gloss textured white baked enarnel finish over a baked enamel prime coat. 
12. SUSFENDED ACOUSTICAI CEII.TNGS (METAI PAN) (Continued)

c. Front and back panels of steel shall be laminated and reinforced every 2" 0.C. With an expanded kraft honeycomb core. Sound absorbing elements shall be fibrous glass and shall be free of shot and slag.

d. Noise reduction coefficient range shall be no less than $.65-.75$ and the Et tenuation shall be no less than 39.3 average db when tested according to Acoustical Materials Association's Test No. AMA 1-11 of 3-1-59. Certified copies of test showing above results must be furnished to the Commission prior to approval of materials.

e. ceiling panels shall provide complete access and shall be free from "breathing", with a solid steel back. All field fabrication shall be taped after cutting, with a tape as recommended by the manufacturer or metal clcsures shall be used.

f. Perforated front panel and unperforated back shall be mechanically locked together by a lock seam process to insure against delamination.

g. The exposed Tmgrid suspension shall be furnished by the manufacturer of the acoustical ceiling panel and shall be provided with a textured nongloss finish similar to the finish on the acoustical ceiling panels, so that grid and panels shall match. The suspension system shall have clearances so as not to interfere with removal of the acoustical panel. Hanger wi res shall be No. 12 gauge, annealed and galvanized. Hanger wires shall be installed at all four corners of recessed light troffers.

h. The Kemp Corp. "Soundlock" metal pan acoustical ceiling is an example of a material meeting the requirements stated above.

\section{WORKMANSHIP}

13. DELIERI AND STORAGE OF MATERTATS

All materials for use in the work of this division shall be delivered to the job site in the manufacturer's original containers with labels intact and seals unbroken. All materials shall be stored in a dry, well ventilated apace and as recommended by the manufacturer, until used.

14. EEFCTION OF WIRE AND METAL IATH FOR PIASTER AND STUCCO

a. Framing for plaster partitions shall be securely attached to floors, ceilings and intersecting walls. Floor clips shall be used on concrete floors and ceiling runner used where partitions join metal roof deck, metal window mullions and concrete block walls. Sheet metal screws or welding may be used for metal connections. Machine screws and anchors shall be used for connections to concrete. Ceiling runner shall serve as a plaster ground. 
14. EREOTION OF WIRE AND METAL IATH FOR PIASTER AND STUCCO (Contimued)

b. Furred partitions at pipe spaces, etc., shall be braced to concrete and masonry walls with steel braces and clips. Furred partitions shall be finishez on outside only. Furred partitions shall have $3 / 4$ inch metal cinannel reinforcing tied horizontally on 54 inch centers or less (see arswing $\mathrm{H}-3-20546$ for relnforcement for wall hung cabinets).

c. Metil corner beads shall be installed on all exterior corners where other trim is not shown on the drawings.

d. A $3 / 4$ inch channel shall be installed over all door openings and above end below duct openings and extended beyond the opening to connect to 2 studs on each side of the opening for reinforcement.

e. Metal leth shall be wired to studs and reinforcing as recomended by the Iath manufoaturer. Laps between sheets shall be 1-1/2 inches. Inside corners shail be reinforced with pieces of lath extending a minimum of 3 inches each way from the corner. Apply lath on ceilings before lath is applied on walls and carry ceiling lath down 6 inches onto walls which are to receive lath. Lath on vertical surfaces shall be applied from the top down, with the top sheet lapping over the extended portion of the lath from the ceiling. In general lath should be placed so that tine lower sheet laps over the upper sheet.

f. Where plistex partitions occur under metal pan ceilings, the ceilings shall be installed first. Ceiling grid and plaster partition framing shall be fastened together so that the partitions obtain lateral support from the ceiling.

g. Wire reinforcing of the type specified in section 9a. above shall be attached to masonry walls as recommended by the manufacturer of the wire.

r. Wire mesh with waterproofmpaper backing, as specified in section 9b. above, shall be fastened to nailable steel studs prior to applying stucco.

i. Ceiling furring channels shall be spaced 16 inches on centers and tied at joints with 2 strands of No. 16 wire. Supplementry structural steel framing shali be installed where necessary to support the ceiling.

j. Metal lath shall be tied with No. 18 wire to all channels at 6 inch intervals.

k. Irsulation tabs shall be fastened to nailable steel studs with roofing nails with minimum $3 / 8$ inch head or wall board nails nailed through tin dises. Insulation shall be recessed approximately $3 / 4$ inch to provide an zir space between plaster keys and face of insulation.

1. Apcly lath with long dimension of sheets across supports. 


\section{ERECTION OF METAI PAN CEIIINGS}

$\Leftrightarrow$ Min $T$ runners shall be placed 2 feet $0 . C$. and suspended with 12 gauge galvanized wire. Cross $T$ members shall rest on the flanges of main $T^{2} s$ and shall lock in place. Supplementary structural steel framing shall be installed where necessary to support the ceiling.

k. Mogrid shall be held level and true in order that acoustical panels may Isy perfestiy flat. Fanels shall be supported around the entire perimeter of the panel. Ceiling surfoce shall not vary from a horizontal plane by more than $178^{\prime \prime}$ in any 8 ' span.

c. Iugxid shall be fastened to wall surfaces. Bottom flange of T's shall be trimmed back flush with wall molding so that the wall molding supports one edge of panels. Wall molding shall be mitered at corners.

\section{MTXING FIASTER}

a. Gypeum cement plaster for base coats shall be hand mixed while dry, in watew wight box and water added, or plaster shall be machine mixed.

b. If plaster is machine mixed, wet mixing time shall not be less than 2 minutes and the mixer shall be thoroughly cleaned after each batch. Matexis l that has partially set shall not be retempered or used.

c. No more plaster shall be mixed than can be used within one hour.

d. Gysim zement plaster for scratch cost on metal lath shall be mixed in the following proportions, by weight:

1. part plsster

2. parts ssind

e. Grpeum cement plaster for base coat on masonry shall be mixed in the following proportions, by weight:

1 part plaster

3 parts sand

f. Fibishing lime shall be prepsred by mixing 5-1/2 to 6 gallons of water pex bag of lime. Iime putty may be mixed by hand in a waterwtight box or by machine. Care shall be taken to see that lime putty does not become crusty or dried out. Crusted material shall be discarded. Iime putty shill be screened through a No. 10 sieve immediately before use.

B. Haxd gauging - lime putty finish plaster shall be mixed in the following proportions, by weight:

$100 \mathrm{lb}$. hard gauging plaster

200 .16. Iime putty 
17. FLA.THPINY

IT.1 MASONRY WAIIS

a. Plaster on masonry surfaces shall be as follows:

Bese - gypsum cement plaster - 5/8 inch thick, applied in two coat.s. Finish soat - hard gauging - lime putty finish - $1 / 8$ inch thick.

Total $-3 / 4$ inch thick.

Base coats shall completely embed the wire reinforcing.

b. Suratah coat plaster on masonry shall be applied with sufficient ingtexila and pressure to obtain good keying action in masonry joints snd good bond on faces of concrete block. First coat shall be scratched sad allowed to partially axy prior to application of brown coat.

c. Brown cost shall be screeded for leveling but shall be scratched lightly to receive succeeäing coat.

\subsection{METEL IATH AND PIASTER PARTITIONS}

a. Fustering on metal lath shall be applied in 3 coats.

b. On 2 inch solid partitions, the seratch coat shall be applied on lath side and allowred to set and partially dry. Back up coat shall then be applied in not less than two operations to give thickness sufficient to corer grounds. Brown coat shall then be applied in thickness to bring total thickness of paxtition to $1-3 / 4$ inches.

c. Finish coat piaster shall be applied $1 / 8$ inch thick over brown coat on paxtitions and over base coat on masonry walls. Finish coat shall be troweled to dense, smooth finish and checked with a $5^{\prime}$ straightedge.

a. Srratch and brown coats shall be screeded for leveling but shall be left rough to receive succeeding coat.

e. Furred partitions around pipe spaces etc., shall be plastered on one side only. Scratch coat shall be $3 / 8$ inch thick, brown coatil/4 inch thick, and finieh coat $1 / 8$ inch thick.

\subsection{FLASITP CEILINGS}

a. Celling plaster shall be $3 / 4^{\prime \prime}$ thick and shall be applied the same as specified for furred partitions in section $17.2 e$. above.

b. The textried finish to be applied on ceilings of Rooms 103 and 104 shail be as agreed upon by the Commission and the Contractor prior to appifection of plaster. 


\subsubsection{TENT:JIATION AND CURTHG}

2. Plaster shall not be applied when the ambient temperature is below $50 \mathrm{~F}$. If the tempergture outside the building is below $50 \mathrm{~F}$ when plastering is to be done, a source of heat shall be installed and window and door openings in outer walls covered.

b. While plastering is in progress the air temperature within the spaces being plastered shall be maintained within the range $50 \mathrm{~F}$ to 75 . F. Tempersture range shall be maintained for 48 hours after plastering is completed.

c. If it becomes necessary to heat the spaces where plastering is in progress fais shall not be permitted to blow warm, dry aix directly against a plastered surface which is less than 3 days old.

18. MIXING AND APPLICATION OF STUCCO

5. Stucco shall be machine-mixed. No more material shall be mixed than wili be used within 30 minutes. The mixer drum shall be cleaned after mixing each batch. Retempered or partially-set material shall not be used.

b. Strsco shall be mixed in the following proportions:

(1) Scratch coat

I bag portland cement

2 bags hydrated lime

$2 \mathrm{Ib}$. fiber

$7 \cdot 1 / 2$ cu. ft. sand

(2) Finish coat

1 bag portland cement

2 bags hydrated lime

9 cu. ft. sand

c. The scritch coat shall be applied to a thickness of $3 / 8$ inch. Scratch cost shall be held back from edges of panels to allow keying of finish coat. Soratch coat shall be allowed to partially set and crossuscratched to improve adherence of finish cost.

a. Finish cost shall be applied to a full $3 / 8$ inch thickness. White stone chips shall be deposited before finish coat has set. Stone chips shall be deposited in a uniform dense pattern over the surface.

e. Eoth scratch coat and finish coat shall be kept damp for a minimum of 24 hours after application. A fine fog-spray nozzle shall be used for applying water. Only as much water as can be absorbed shall be used. Water shall not be allowed to run down the surface. 
18. MIXXNG AND APPLICATION OF STUCCO (Continued)

f. Stucco surfaces shall be brushed lightly 3 days after placement to remove loose and poorly-adhering chips.

19. REPATR OF STUCCO AID PLASTER

A.II cracks, gouges, checks or other damage to plaster or to stucco shall be repaired. Cracks and shallow spalls shall be chipped out and roughened so that the repair material will adhere properly. 


\section{DIVISION TX}

METAI WAI工 PANELS AND INSUTATED SIDINVG

GENERAL

\section{2. $\quad 350 \mathrm{FE}$}

This ilvision covers all interior metal wall panels and exterior, insulated metal siding for the Fuels Recycle Pilot Plant, Building 324.

\section{FEFEFEWHED SFECIFLCATIONS}

The specifications and standards listed below form a part of this specification to the extent indicated by subsequent references.

\section{I AMERDCAN STANDARDS ASSOCIATION (ASA)}

ASA Al16.1-1960 Polysulphide-Base Sealing Compounds For the Building Trade

\subsection{FEDERAI SPEXIFICATIONS}

$H H-I=521 c$

QQ०S-7?5a

$\operatorname{Tin}=6-598$
Insulation, Minerigl Wool, Batts, Loose Fill and Granular Fili Steel, Sheets, Carbon, Zinc-Coated

Compound, Caulking, Plastic

\section{MATERIAIS}

3. TNSTISTED METAI WAII PANEIS

2. Insulsted metal wall panels for exterior siding shall have a smooth interior face sheet and a fluted exterior sheet with $1-1 / 2$ inch deep, roduiar fiutes which are generally rectangular in section. Fanels shall be 24 inches wide and shall be formed from zincocoated steel sheets eonforming to Federal Specification QQ-S-T75a, Type I, Class E. Face renels shall be given a shop coat of zinc chromate primer at the manufacturer's plant.

b. The panel assembly shall be capable of withstanding a wind load of 20 pounds per square foot with a deflection of not more than $1 / 180$ of the epan for a simple span of 12 feet, 6 inches.

c. Insulation shall be glass fiber, in batt or semi-rigid board form. Density of the insulation shall be not less than $2-1 / 21 \mathrm{~b}$. nor more than $6 \mathrm{lb}$. per cubic foot. Insulation shall conform to Federal specification $H H-I-52 I c$, Type I, Class A. 
3. INSURATED METAI WAII, PANEIS (Continued)

d. The overail coefficient of heat transmission of the assembled parel, in still air, shall be not greater than $U=0.15 \mathrm{Btu} . / \mathrm{hr} . / \mathrm{sq}$. ft $/$ degree $F$. temperature differential. The contractor shall submit test data developed by an inderendent laboratory showing that the paneis proposed for use under this specification comply with this requirement. Test data shaiI show the average rate of heat transmission for at least 3 test panels ineluiing a rinimum of 2 side joints.

e. Wall panels shail be supplied in lengths to span at least 3 supports wherever possible.

f. Eoth interior and exterior face sheets shall be formed with male and female eüges to provide a side joint which can be sealed air tight and can ve male fast mechuniceliy. Joints in exterior face sheets may be fictory-arulked.

s. Panels shell be furnished complete with galvanized steel closure strixs and flashing fabricated by the panel manufacturer from material conforming to Federa Specification QQ-S-7T5a, Type $r$, Class E. Closure strips shail se IE gauge $B x_{S}$, and shall conform to the requirements shown on the ararings. Cadmium plated steel or stainless steel self-tapping screwe shal: be furnished for fastening closures and flashings in place.

i. Ioose fill insulation for wall insulation at jambs and corners shall be minersi wool conforming to FederaI specification HH-I-52Ic, Type II.

i. Insuleted metal wall panels shall be furnished with sub-girts for fastering exterior face sheet to the interior sheet to eliminate visibie exterior festenings. Sub-girts shall be insuiated at fastening points to prevent direct metal to metal conduction of heat through the panel.

j. Ome end of each exterior face sheet shall be counter sunk and sized to fit sheet above to provide a smooth-surfaced, lap joint of at least $a$ inches.

\section{METAI FANTEL PARTIPIONS}

8. Interior metel wall panels shail be single thickness panels with $1-1 / \hat{c}$ Ines deep, modular flutes which are generally rectangular in section. Pamels shall be formed from galvarized steel sheets conforming to Federal Spedication QQ-S-775a, Type I, Class E. Partition panels shall be costed on both sides with zinc chromate primer in the manufacturer's shop. Primer shall be as specified in Division XVI.

b. Panels shall be formed with a fenale lip on one edge and a male lip on the other edge so that the joint may be sealed air-tight between ventilstion zones. Panels shall ke furnished with cadmium piated or stizirless steel, self-tapking screws for mounting. 
4. METAT EANEI FAFTITTONS (Continued)

c. Panels shall be furnished in the longest lengths usable in the work and shall sf:n a minimum of 3 supports wherever possible. Panels shali be 2h. Inches in width.

d. Panels shall have sufficient strength and rigidity to withstand a losd of 15 poinds per square foot without deflecting more than $1 / 180$ of the span over $\approx$ simple span of 12 feet, 6 inches.

e. Cne end of each sheet, shall be countersunk and the other end sizel so is to provide a smooth end lap joint. Minimum lap shall be 2 inches. Cisosed ceil, neoprene closure strips shall be furnished by the panel menufgcturer for use where shown on the drowings.

f. Where interior metal partitions are shown on the drawings as double thicknes: panels the sheet facing the interior of the space so enclosed shall be of the same material and configuration as the interior face sheet of the insulated wail panels specified in section 3. above.

\section{SFAIING AND CAUEIING COMPOUNDS}

E. Wherever caulked seams and joints are called for on the drawings the Inatexial used shall conform to the requirements of Federal specification Fon -598 , Grode 2 (knife grade).

k. Wherever seaisnts or sealing compounds are specified on the drawings, the miterial used for this purpose shall conform to the requirements of ASA A116.1.

\section{WORKMANSHTP}

\section{EREOWION OF INSUTAMED METAI WAIT FANEIS}

ڤ. Interior face sheets of insuiated metal wall panels shall be attached to the building framing by plug welding or with sheet metal screws. Each sheet shall be fastened to each support in 3 places; one plsce near each edge and one as near the center as possible.

b. The interior face of exterior metal panel walls shall be sealed as airtight as possible. The female lip of interior sheets shall be filled with folysulthide sealant of the type specified in section 50. akove. When adjacent sheets have been joined and fastened in place the groove that is visible from the interior side of the wall shall be fillel flush with the face of the sheets with polysulphide rubber sealant. Any excess seaiant extruding from the groove shall be removed with a putty knife. 
6. FPEIXION OF TNSUATED METAI WATI PANELS (Continued)

$\therefore$ Insulation and sub-girt,s shall then be installed and the exterior face sheets st tached to the sub-girts in such a manner that fasteners are not risible on the exterior of the building.

d. Insulstion retainer strips and parel closure strips shall be fastened in place with cadmium plated or stainless steel, self-tapping, sheet metal screws.

i. EFEOTION OF METAL PANE PARTITIONS

2. Interior metal partition panels shali be attached to structural framing by use of cadmium plated or stainless steel self-tapping screws.

5. Fensite lips of paneis shall be filled filush with the face of the sheets with polysulphide rubber sealant immediately before erection. Any excess sealant extruding from the groove shall be removed with a futty knife. Side joints shall be made mechanically fast by crimping at intervals of 36 inches with a tool made specifically for this purpose.

c. Molded neoprene closure strips shall be installed where show on the drewings and the joint sealed with polysulphide rubber sealant to prevent leaksge of air between rooms.

d. Metal closure strips shall be installed as stops at top and bottom of Inner face sheet where double sheet construction is indicated on the drawings. Inner and outer face sheets shail be fastened together securely so that tapping with the hand will not produce rattling. All fiachings, coliars around fenetrations, etc., shall be as indicated on the dratrings to satisfactorily sheath the structure and make it as wearhere and air-tight as possible. 


\section{DIVISION $\mathrm{X}$}

HEATING AND VENTIIATING

GENERAL

1. $\mathrm{SCCPE}$

Mris division covers heating and ventilating for the Fuels Recycle Pilot Plant, Building 324, except for electric baseboard heating and wiring work for unit heaters and duct heaters which is specified in Division XVII.

2. SUBMTSSION OF DRAWINGS AND INFORMATION

a. The Contractor shall furnish to the Commission the following items of information covering the equipment specified in this Division in ascordance with requirements stated in the Special Conditions.

(1) Dimensioned shop and installation drawings.

(2) Characteristic curves for all fans. Fan curves shall be certified by the manufacturer.

(3) Wiring diagrams for electric powered equipment.

(4) Equipment specifications including capacities and restrictions.

(5) Lubrication and maintenance instructions.

(6) Spare parts lists.

b. Items (1) through (4) shall be furnished to the Commission, for approval, prior to purchase of equipment by the Contractor.

c. Final approved copies of all items, listed in paragraph a. above, shall be furnished at the time of shipment of equipment to the job site.

3. REEERENCED STANDARDS AND SPECIFICATIONS

The standards and specifications listed below form a part of this specification to the extent indicated by subsequent references.

\subsection{AMERTCAN SOCIETY FOR TESTING AND MATERIALS (ASTM)}

ASTM AI65-55, ASTM AI67-6IT, ASTM A276-60T, ASTM A307-61T,

ASTM A312-61T, ASTM A320-59T, ASTM B32-60aT, ASTM B209-51, ASTM B 308-61, ASTM B241-61,
Electrodeposited Coatings of Cadmium on Steel Corrosion-Resisting Chromium-Nickel Steel Plate, Sheet \& Strip Hot-Rolled \& Cold-Finished Corrosion Resisting Steel Bars Low-Carbon Steel Externally and Internally Threaded Standard Fasteners

Seamless and Welded Austenitic Stainless Steel Pipe Alloy-Steel Bolting Materials for Low-Temperature Service Solder Metal

Aluminum-Alloy Sheet and Plate

Aluminum-Alloy, Structural Shapes, Rolled or Extruded Aluminum-Alloy Pipe 


\subsection{AMERICAN STANDARDS ASSOCIATION (ASA)}

ASA B18.1-1955, Small Solid Rivets

ASA B27.2-1958, Plain Washers

ASA Al16.1-1960, Polysulphide - Base Sealing Compounds For The Building Trades A'A 59.1 - 19'38, Sal'ety Code for Mechanical Refrigeration

3.3 AMERICAN SOCIETY OF MECHANICAL ENGINEERS (ASME)

Dsstion VIII, Code for Unfired Pressure Vessels

3.4 ANR MOVING AND CONDITIONING ASSOCIATION (AMCA)

Standards for Fans, Class I, II and III

3.5 AMTT-FRICTION BEARING MANUFACTURERS ASSOCIATION (AFBMA)

Standards for Ball and Roller Bearings and Steel Balls, 1959

\subsection{FEDERAI STANDARDS}

No. 595 , Colors

\subsection{TEDERAL SPECIFICATIONS}

FT-C-598, Compound, Caulking, Plastic

TT-E- 4899 , Enamel, Alkyd, Gloss

TT-P-86a (i), Paint, Red-Lead Base, Ready-Mixed

3.8 HANFORD STANDARDS AND SPECIFICATIONS

Fits-7508-S, Rev. 1, Low Pressure Air Ducts

FNS-7511-S, High Efficiency Particulate Air Filters

$\mathrm{EN}-\mathrm{M}-4-6$, Machinery Guards

\subsection{MIITARY STANDARDS}

MIL-STD-282, 5-28-56, Performance Test Methods for Filter Units, Protective Clothing, Gas Mask Components and Related Products

3.10 AMERICAN FILTER INSTITUTE (AFI)

AFI Dust Spot Test Code - 1960

3.I1 STEEI STRUCTURES PAINTING COUNCIL (SSPC)

SSPC-SP6-52T, Commercial Blast Cleaning 


\section{MATERTAIS}

4. FRIXESS AREA SUPPIIS FAN UNIT - EFN 324-8900-901 (1 REQUIRED)

4.2 FRAN

2. Suply fen shall be manufacturer's standard conforming to Air Moving sud Coxititioning Association Ine. Stsndards.

b. Far shall be centrifugal tyce with backwardly inclined blade wheel and sor -overiosding power characteristics. Wheel shall have a minimum rominai diameter of 66 inches.

c. Fer rotox shall have an individual running balance test at the manufeeture $r^{\circ} \mathrm{s}$ plant and shall be dynsmieally balanced to meet the reguiremexis of the installed dispiacement test listed below. The peak cotoweak amplitude of vibration of the installed fan, when zessured on the shaft or besxing caps in the horjzontal and vertical. planes at the rated flow, static pressure and speed, shall not exceed 0.002 inches. Displacement may be measured by an Internstional Research and Development Vibration Analyzer or similar portable instyument. There shail be no exitical speed through which the fan mast pass from 10\% above normal speed and below.

d. Isin shili be designed and fabricsted in accordance with the following requirements:

(1) Air Moving and Conditioning Association Class II Construction.

(a) Doubie inlet, double width.

(3) Counter-olockwise rotation, $45^{\circ}$ top angular up discharge.

(if) Arrangement 3 .

(5) Motor position Z.

6) Koted capacity shall be $81,000 \mathrm{cfm}$ at $31 / 2$ inches water gage static pressure with $70 \mathrm{~F}$ air at sea level.

(7) Fan base shall be properly flanged for attechment to the isolation base.

(8) Besrings shall be anti-friction type and shall be designed for a B-10 life, as defined by AFM, of at least 10,000 hours. A miximm service factor of 2 shali be applied in the selection of the bearings.

e. At the reted fan rom, the fan characteristic curve shall be continuously arooping at the roint of rated capscity and for at least one inch static pressure above and below the corresponding static pressure rating. 


\subsection{FAN}

\section{e. (Continued)}

(1) There shall be only one point of intersection on the characteristic curve at the design static pressure which shall be a minimum of 1.0 inches water gage below the maximum static pressure developed by the unit at the rated rpa.

(2) Acceptance or rejection of a unit may be on the basis of the characteristic curve submitited for the unit.

f. Fon discharge connection shall be flanged. Inlet connection shall be per manifacturer's standard.

g. Fan casing shall be split with flanged and bolted connections. Casing access plates shall be provided. Overall width measured at the fan inlets, including radial inlet dampers, shall not exceed $9^{\circ}-0^{\prime \prime}$.

b. The fan shall have a radial inlet damper on each side consisting of throat mounted variable inlet vanes connected to a central control lever. All vanes on both sides of fan shall operate simultaneously and shail be in the same relative position. Material and type of construction shall be manufacturer's standard. Brackets and linkages shall be provided, as necessary, for mounting and connecting to damper operator.

(a) Damper operator shall be sized to provide at least $120 \%$ of damper torque requirements at design conditions. Number and size of operators is optional.

(b) Damper and damper operator shail be so arranged that damper fiI take a normally closed position upon intermption of air pressure.

(c) Operator shall be of the air-operated, springmeturn modulating type with pilot positioner.

(a) Control air pressure for the positioner is at 3-15 psig while 40 psig air is available for the damper operator.

(e) Damper operator shall be supplied with a diaphragm seal to prevent; leakage. Adjustable stops shall be provided to adjust. lengich of stroke.

(f) Pilot positioner shall be supplied with gauge and by-pass manifold. It shall be mounted directiy on damper operator. 
4.1. EAN

n. (Continued)

(E) Damper operator shall be mounted on the fan. Damper linkages shall be connected to the operator and shall be adjustable.

4.2 DISCHARGE DAMPER - EPN 324-8900-901A ( I REQUIRED)

a. Counterbalanced back draft damper shall be of welded and/or riveted ceribon steel construction.

b. The damper shall be reasonably airtight having a maximum leakage of $5 \%$ of the reted flow (based upon the fan discharge velocity at the rated differential).

c. Damper blade axes shall be horizontal.

d. Single tinickness blades shall be 12 gauge minimum thickness with interlocking edges. Airfoil design with double-thickness blades shall be 16 gauge minimum, welded construction, but the edges need not be interlocking.

e. Blade width shall be 4 inches minimum and 10 inches maximum.

f. Blede shafts shall be $1 / 2$ inch minimum diameter.

g. Bearings shall be standard low pressure, bronze sleeve, friction bearings for leaves and anti-friction ball bearings for connection to counterobalance.

Frome shall be 12 gauge minimum and sized to fit the fan discharge. Frame shall be approximately 8 inches face to face and have flanged ends. A flexible connection will be installed, in the field, between the fan discharge and the damper.

h. Damper shall be provided with continuous angle end stops.

i. The countermbalance shall be externally mounted on a through shaft and shall be readily adjustable in the field. Counter-balance shall be on the right-hand side when facing in the direction of air flow. The dampex frame will be mounted paraliel to the fan discharge frame in the I’ield.

4.3 FAN MOTOR

a. Motor shall be $75 \mathrm{hp}$ (minimum), $1200 \mathrm{rpm}$, three phase, 440 volt, 60 cycle. 


\subsection{FAN MOTOR (Continued)}

b. Motor shall be manufacturer's standard, with single end shaft, conforming to the following requirements:

(1) Motor shall conform to the standards of NEMA and AIEE for ratings, performance characteristics, insulation values and mounting dimensions, with a service factor of $115 \%$.

(a) Motor sha.1 be $55 \mathrm{C}$ rise over $40 \mathrm{C}$ ambient, continuous rating, norms l torque, normal starting current and shsll be equipped with ba.11 bearings and dripproof frame.

(3) Motor shall be designed for grease lubrication and shall be equipped with lubrication fittirigs and relief plugs or openings.

(4) Motor base shall be equipped with steel slide rail or equivalent for adjustment of belt tension. Slide rajl shall provide a minimum installation and tske up allowance for belt adjustment in accordance with the belt manufacturer ${ }^{\prime}$ s recommendations.

\subsection{FAN DRIVE}

2. Tobelt sheaves shsil be of two-niece construction consisting of a hub having an internal key slot and an external taper. The hub shall be split axialiy opposite the key siot. The hub mating surface of the shesre shail also be tapered so that after installation, the hub will securely grip the shaft equivalent to $a$ shrunk on fit with no wobble between components. It shall be possible to install or remove the sheave sssemblies in the field without benefit of heat or special tools and without shock to bearings or machinery. Sheaves shall be dynamically balanced at the manufacturer ${ }^{\circ} \mathrm{s}$ plant to within two incheounces or less.

b. Belts shall be matched and shall be designed for 150 percent of driving motor horsepower rating.

c. A personnel guard, conforming with Hanford Standard Mol ${ }^{2} 6$, shall be provided around the V-belts and drive sheaves.

d. Manufacturex"s standard wire mesh guard shall be installed at the fan inlets.

\subsection{FRN BASE}

2. The fan and motor shall be isolated from the building floor by comm vibration ard sound absorbing base. 


\subsection{FIS BASE (Continued)}

b. The isojation base shall be a single unit of all welded steel construction.

c. The isolators shall be the spring type with the size and number as required to be cafable of $95 \%$ damping efficiency based upon the jisturbing frequencies for $10 \%$ above to $25 \%$ below the rated speed of ihe fan and the number of biades in the fan rotor. The isolators sbali be adjustable for leveling and lateral snubbing and be equipped ith rubber inserts to prevent metal to metal contact.

\subsection{FINISH}

a. Prior to delivery, all foreign material, mill scale, oxidation, etc., shsil be removed and a metal protective primer appiied in accordance wth the manufacturer's standard practice. Cieaning shall conform to SSPC-SPE.

b. All equipment shall be finished with light gray machinery enamel. Color shall match No. 16329 of Federal standard No. 595.

5. FROCESS AREA SUPPLY FAN UNIT - EPN 324-8900-902 (I REQUIRED)

The suppiy fan mit shall be the same as specified under Section 4 above except the jischarge damper shall be marked EPN 324-8900-902A.

6. ADMIN STRATION AREA SUPPLY FAN UNTT - EFN 324-8900-903 (1 REQUIRED)

\subsection{FAN}

a. Supply fan shall be manufacturer's standard conforming to Air Moving ard Conditioning Association Ine. Standards.

b. Fen shall be centrifugal tyce, backwardly inclined blade wheel with non-overioeding power characteristics. Wheel shall have a minimun nowina: diameter of 40 inches.

c. Far rotor shall have an individuai running balance test at the manufarturer's plant and shall be dynamically balanced to meet the reguirements of the installed aisplacement test listed below. The pesik-to-peak amplitude of vibration of the installed fan, when measured on the shaft or bearing csps in the horizontal and vertical plenes at the rated flow, static pressure, and speed, shall not exseed 0.002 inches. Displacement may be measured by an International Research and Development Vibration Analyzer or similar portable instrument. The $=$ shall be no critical speed through which the fan must pass from $10 \%$ above normal speed and below. 


\subsection{FAN (Continued)}

d. The fan shall be designed and fabricated in accordance with the following requirements:

(1) Air Moving and Conditioning Association Class I construction.

(2) Single inlet, single width.

(3) Counter clockwise rotation, up blast discharge.

(4) Arrangement 9I.

(5) Motor position: Ieft hand side of drive when facing driving side of fan.

(6) Rated capacity shall be $18,800 \mathrm{cfm}$ at $21 / 2$ inches water gage static pressure with $70 \mathrm{~F}$ air at sea level.

(7) Fan base shail be properly flanged for attachment to the isolation base.

(8) Bearings shall be anti-friction type and shall be designed for a B-I0 life, as defined by AFBMA, of at least 10,000 hours. A minimum service factor of 2 shall be applied in the selection of the bearings.

e. At the rated fan $\mathrm{rpm}$, the fan characteristic curve shall be continuously drooping at the foint of rated capacity and for at least one inch static pressure above and below the corresponding static pressure rating.

(1) There shall be only one point of intersection on the characteristic curve at the design static pressure which shail be a minimum of 1.0 inches water gage below the maximum static pressure developed by the unit at the rated rpm.

(2) Acceptance or rejection of a unit may be on the basis of the characteristic curve submitted for the unit.

f. Fan discharge connection shali be flanged. Inlet connection shall be per manufacturer's stendard.

g. Fan casing shall be split with flanged and bolted connections. Casing access plates shall be provided.

h. Fan shall have a radial inlet damper consisting of throat mounted, variable inlet vanes connected to $\varepsilon$ centrail control lever. MateriaI and type of construction shall be manufacturer's standard. Brackets and linkages shall be provided, as necessary, for mounting and connecting to damper locking quadrant. Damper locking quadrant shaiI be mounted on the fan. 


\subsection{FAN MOTOR}

a. Motor shall be $15 \mathrm{hp}$ (minimum), $1200 \mathrm{rpm}$, three phase, 440 volt, 60 cycle.

b. Motor shall be manufacturer ${ }^{8}$ s standard, with single end-shaft, conforming to the following requirements:

(1) Motor shall conform to the standards of NEMA and AIEE for ratings, performance characteristics, insulation values and mounting dimensions, with a service factor of $115 \%$.

(2) Motor shall be $55 \mathrm{C}$ rise over $40 \mathrm{C}$ ambient, continuous rating, normal torque, normal starting current, and shall be equipped with ball bearings snd dripproof frame.

(3) Motor shall be designed for grease lubrication and shail be equipped with lubrication fittings and relief plugs or openings.

(4) Motor base shall be equipped with steel slide rails or equivalent for adjustment of belt tension. Slide rail shall provide a minimum installation and take-up allowance for belt adjustment in accordance with the belt manufacturer's recommendations.

\subsection{FAN DRIVE}

a. Vabelt sheaves shall be of two-piese construction consisting of a hub having an internal key slot and an external taper. The hub shall be split axially opposite the key slot. The hub mating surface of the sheave shail also be tapered so that after installation, the hub will securely grip the shaft equivalent to a shrunkmon fit with no wobbie between components. It shall be possible to install or remove the sheave assemblies in the field without benefit of heat or special tools and without shock to bearings or machinery.

b. Belts shall be matched and shall be designed for 150 percent of driving motor horsepowex rating.

c. A personnel guard, conforming with Hanford Standard Machinery Guard M-4.66, shall be provided around the Vabelts and drive sheaves.

\subsection{FAN BASE}

a. The fan and motor shall be isolated from the building floor by $a$ common vibration and sound absorbing base. 


\subsection{FAN BASE (Continued)}

b. The isolation base shall be a single unit of all-welded steel construction.

c. The isolators shall be the spring type with the size and number Bs required to be capable of $95 \%$ damping efficiency based upon the disturbing frequencies for $10 \%$ above to $25 \%$ below the rated speed of the fan and the number of blades in the fan rotor. The isolators shall be adjustable for leveling and lateral snubbing and equipped with rubber inserts to prevent metal to metal contact.

\subsection{FINISH}

(1) Prior to delivery, all foreign material, mill scale, oxidation, etc., shall be removed and a primer applied in accordance with the manufacturer's standard practice. Ciearing sinall coniorm to Sipc-

(2) All equipment shall be finished with light gray machinery engmel. Color shall match No. 16329 of Federal Standard No. 595.

7. PROCESS AREA VENIIIATION ZONE II EXHAUST FAN UNIT EPN 324-8900-971 (I REQTIRED)

\subsection{FAN}

a. Exhaust fan shall be manufacturer's standard conforming to Air Moving and Conditioning Association Ine. Standards, complete and ready for use.

b. Fan shall be centrifugal type, backwardly inclined blade wheel with non-overloading power characteristics. Wheel shall have a minimum nominal diameter of 49 inches.

c. Fan rotor shall have an individual running balance test at the manufacturer's plant and shall be dynamically balanced to meet the requirements of the installed displacement test listed below. The peak-to-peak amplitude of vibration of the installed fan, when measured on the shaft or bearing caps in the horizontal and vertical planes, at the rated flows static pressure, and speed shall not exceed 0.002 inches. Displacement may be measured by an International Research and Deveiopment Vibration Analyzer or similar portable instrument.

d. The fan shall be designed and fabricated in accordance with the following requirements: 


\subsection{FAN}

d. (Continued)

(1) Air Moving and Conditioning Association Class II construction.

(2) Single inlet, single width.

(3) Clockwise rotation, $45^{\circ}$ top angular down discharge.

(4) Arrangement 1.

(5) Motor position $Y$.

(6) Rated capacity shall be $35,200 \mathrm{cfm}$ at 5 inches water gage static pressure with $70 \mathrm{~F}$ air at sea level. Fan will operate with air at approximately $80 \mathrm{~F}$.

(7) Fan base shall extend to the floor and be properly flanged for attachment to the isolation base.

(8) Bearings

Bearings shall be anti-friction type and shall be designed for a $B=10$ life, as defined by AFBMA, of at least 10,000 hours. A minimum service factor of 2 shall be applied in the selection of the bearings.

e. At the rated fan rpm, the fan characteristic curve shall be continuously drooping at the point of rated capacity and for at least one inch static pressure above and below the corresponding static pressure rating.

(1) There shall be only one point of intersection on the characteristic curve at the design static pressure which shall be a minimum of 1.0 inches water gage below the maximum static pressure developed by the unit at the rated rpm.

(2) Acceptance or rejection of a unit may be on the basis of the characteristic curve submitted for the unit.

f. Fsn discharge connection shall be flanged. Inlet connection shall be per manufacturer's standard.

g. Fan casing shall be split with flanged and bolted connections. Casing access plates shail be provided.

h. Fan shall have a radial inlet damper consisting of throat mounted variable inlet vanes connected to a central control lever. Material and type of construction shali be manufacturer ${ }^{\circ}$ s standard. Brackets and linksges shall be provided, as necessary, for mounting and connecting to damper operator. 


\subsection{FAN}

h. (Continued)

(1) Damper operator shall be sized to provide at least $120 \%$ of damper torque requirements at design conditions. Number and size of operators is optional.

(2) Operator shall be of the balanced, air-operated modulating type with pilot positioner.

(3) Control air pressure for the positioner is at $3-15$ psig while 40 psig air is available for the damper operator.

(4) Damper operator shall be supplied with seals to. prevent leakage. Adjustable siops shall be provided to adjust length of stroke.

(5) Pilot positioner shall be supplied with gauge and by-pass manifold. It shall be mounted directiy on damper operator.

(6) Damper operator shall be mounted on the fan. Damper linkages shall be connected to the operator and be properly adjusted.

(7) Operator shall be equipped with a device that will physically lock the operator rod in the controlled position upon loss of air to the positioner.

\subsection{DISCHARGE DAMPER EPN 324-8900-971A ( I REQUIRED)}

a. The discharge damper shall be a counter balanced backdraft damper and shall be of welded and for riveted carbon steel construction.

b. The damper shall be reasonably airtight having a maximum leakage of $5 \%$ of the rated flow (based upon the fan discharge velocity) et the rated differential.

c. Iamper blade axes shall be horizontal.

d. Single thickness blades sha.11 be 12 gauge minimum thickness with interlockjng edges. Double-thickness blades of airfoil design shall be 16 gauge minimum, welded construction, but the edges need not be interlocking.

e. Biade width shall be four inches minimum and 10 inches maximum.

f. Blade shaft.s shall be $1 / 2$ inch minimum diameter and 6 inches minimum length securely pinned or attached to blade.

8. Bearings shall be standard low pressure, bronze sleeve, friction bearings for leaves and antiofriction ball bearings for connection to counter-balance. 


\subsection{DISCHARGE DAMPER EPN 324-8900-971A (1 REQUIRED) (Continued)}

h. Frame shall be 12 gauge minimum and sized to fit the fan discharge. Frame shall be approximately 8 inches face to face and shall have flanged ends. A flexible connection will be installed, in the field, between the fan discharge and the damper.

i. Damper shall be provided with continuous angle end stops.

j. The counter-balance shall be externally mounted on a through-shaft and shall be readily adjustable in the field. The counter-balance shall be totally enclosed in a weatherproof housing having $a$ gasketed access panel. Counter-valance shall be on the right-hana side when facing in the direction of air flow.

\subsection{FAN MOTOR}

a. Motor shall be $40 \mathrm{hp}$ (minimum), $1200 \mathrm{rpm}$, three phase, 440 volt, 60 cycle, totally enclosed ran-cooled type.

b: Motor shall be manufacturer's standard, with single end shaft, conforming to the following requirements:

(1) Motor shall conform to the standards of NEMA and AIEE for ratings, performance characteristics, insulation values and mounting dimensions, with a service factor of $115 \%$ 。

(2) Motor shall be $75 \mathrm{C}$ rise over $40 \mathrm{C}$ ambient, continuous rating, normal torque, normal starting current, and shall be equipped with ball bearings.

(3) Motor shall have three separate thermostats mounted in contact with, or embedded in, the stator windings. The thermostats shail be automatic reset type and the contacts shall open as the winding temperature exceeds the rating. Thermostat leads shall be brought to the connection box.

(4) Motor shall be designed for grease lubrication and shall be equipped with lubrication fittings and relief plugs or openings.

(5) Motor base shall be equipped with steel slide rails or equivaient for adjustment of belt tension. Slide rails shall provide a minimum installation and take-up allowance for belt adjustiment in accordance with the belt manufacturer's recommendations. 


\subsection{FAN DRIVE}

a. V-belt sheaves shall be of two-piece construction consisting of a hub having an internal key slot and an external taper. The hub shall be split axially opposite the key slot. The hub mating surface of the sheave shall also be tapered so that after installation, the hub will cecurely grip the shaft equivalent to a shrunk-on fit with no wobble between components. It shall be possible to install or remove the sheave assemblies in the field without benefit of heat or special tools and without shock to bearings or machinery. Sheave assembly shall be dynamically balanced at the manufacturer's plant to within two inch-ounces or Iess.

b. Belts shall be matched and shall be designed for 150 percent of driving motor horsepower rating.

c. A personnel guard, conforming with Hanford Standard M-4-6, shall be provided around the V-belts and drive sheaves.

\subsection{FAN BASE}

a. The fan and motor shall be isolated from the building floor by a common vibration and sound absorbing base.

b. The isolation base shall be a single unit of all welded steel construction.

c. The isolators shall be the spring type with the size and number as required to be capable of $95 \%$ damping efficiency based upon the disturbing frequencies for $10 \%$ above to $25 \%$ below the rated speed of the fan and the number of blades in the fan rotor. The isolators shall be adjustable for leveling and lateral snubbing and equipped with rubber inserts to prevent metal to metal contact.

\subsection{FINISH}

8. Prior to delivery, all foreign material, mill scale, oxidation, etc., shall be removed and a primer applied to the exterior in accordance with the manufacturer!s standara practice. Cleaning

b. All equipment shall be finished on the exterior with two coats of light gray machinery enamel. Color shall match No. 16329 of Federal Standard No. 595. 


\subsection{FINISH (Continued)}

c. Fan impeller, casing interior, radial inlet damper interior, and discharge damper interior shall be painted with a prime coat of Amercoat 86 and two finish coats of Amercoat 33, or approved equal, applied per coating manufacturer's specifications.

8. PROCESS AREA VENTIIATION ZONE II EXHAUST FAN UNIT EPN 324-8900-972 (I REQUIRED)

The exhaust fan unit shall be the same as specified under section $T$ above except the discharge damper shall be marked EPN 324-8900-972A.

9. PROCESS AREA VENTIIATION ZONE I EXHAJST FAN UNIT EPN 324-8900-973 (I REQTIRED)

The exhaust fan unit shall be the same as specified in section 7 above with the following exceptions:

a. Air Moving and Conditioning Association Class III construction.

b. Wheel shall have a minimum nominal diameter of 30 inches.

c. Rated capacity shall be $14,400 \mathrm{cfm}$ at 10 inches water gage static pressure with $70 \mathrm{~F}$ air at sea level. Fan shall be capable of a periodic flow of $19,400 \mathrm{cfm}$, at reduced head, for the speed of rated normal flow. Fan will operate with air at approximately $90 \mathrm{~F}$.

d. Discharge damper sha.11 be marked EPN 324-8900-973A.

10. PROCESS AREA VENTIIATION ZONE I EXHAUST FAN UNIT EPN 324-8900-974 (I REQUIRED)

The exhoust fan unit shall be the same as specified in Section 9 above except that the discharge damper shall be marked EPN 324-8900-974A.

11. PROCESS AREA VENTIIATION ZONE I EXHAUST FAN UNIT EPN 324-8900-975 (1 REQUTRED)

The exhaust fan unit shall be the same as specified in Section 9 above, except that the discharge damper shall be marked EPN 324-8900-975A.

12. FROCESS AREA VENTIIATION ZONE III EXHAUST FAN UNIT EPN 324-8900-976 (I REQUIRED) 


\subsection{FAN}

a. Exhaust fan shall be manufacturer's standard conforming to Air Moving and Conditioning Association Inc. Standards.

$\because s$

b. Fan shall be in-line airflow centrifugal type, backwardly inclined blade wheel with non-overloading power characteristics. Wheel shall have a minimum nominal diameter of 40 inches.

c. Fan rotor shall have an individual running balance test at the manufacturer's plant and shall be dynamically balanced to meet the requirements of the installed displacement test listed below. The peak-to-peak amplitude of vibration of the installed fan, when measured on the shaft or bearing caps in the horizontal and vertical planes at the rated flow, static pressure, and speed, shall not exceed 0.002 inches when installed. Displacement may be measured by an International Research and Development Vibration Analyzer or similar portable instrument. There shall be no critical speed through which the fan must pass from $10 \%$ above normal speed and below.

d. Fan shall be designed in accordance with the following:
(1) Air Moving and Conditioning Association Class II construction.
(2) Up blast discharge.
(3) Floor mounted, arrangement 9.

e. Housing shall be tubular type to provide straight through, in-line air flow from entrance to discharge. Multiple aerodynamic conversion vanes shall be located immediately following the wheel to redirect the air flow in order to minimize noise. Inlet and outlet diameters shall be identical, to accommodate a single duct size. Flange to flange length of housing including radial inlet damper shall not exceed $6^{\circ} 8^{\prime \prime}$.

f. Rated capacity shall be $17,400 \mathrm{cfm}$ at 5 inches water gage static pressure with $70 \mathrm{~F}$ air at sea level. Fan will operate with air at approximately $80 \mathrm{~F}$.

g. A minimum of 4 mounting brackets shall be located at the air inlet end and be properly flanged for attachment to isolation mounts.

h. Bearings shall be anti-friction type and shall be designed for a B-10 life, as defined by AFBMA, of at least 10,000 hours. A minimum service factor of 2 shall be applied in the selection of the bearings. Bearings shall be designed to withstand the vertical thrust load. 


\subsection{FAN (Continued)}

1. At the rated fan rpm, the fan characteristic curve shall be continuously drooping at the point of rated capacity and for at least one (I) inch static pressure above and below the corresponding static pressure rating.

(1) There shall be only one point of intersection on the characteristic curve at the design static pressure which shall be a minimum of 1.0 inches water gage below the maximum static pressure developed by the linit at the rated rpm.

(2) Acceptance or rejection of a unit may be on the basis of the characteristic curve submitted for the unit.

j. Fan inlet and discharge connections shall be flanged.

k. Fan shall have a throat mounted variable inlet vane damper with the vanes connected to a central control lever. Material and type of construction shall be manufacturer's standard. Brackets and linkeges shall be provided, as necessary, for mounting and connecting to damper operator.

I. The inlet damper operator shall be as follows:

(1) Damper operator shall be sized to provide at least $120 \%$ of damper torque requirements at design conditions. Number and size of operators is optional.

(2) Operator shall be of the balanced air-operated modulating tjpe with pilot positioner.

(3) Control air pressure for the positioner is at $3-15$ psig while $40 \mathrm{psig}$ air is available for the damper operator.

(4) Damper operator shall be supplied with seals to prevent leakage. Adjustable stops shall be provided to adjust length of stroke.

(5) Pilot positioner shall be supplied with gauge and by-pass manifolc. It shall be mounted directly on damper operator.

(6) Damper operator shall be mounted on the fan. Damper linkages shali be connected to the operator and be properly adjusted.

(7) Operator shall be equipped with a device that will physically lock the operator rod in the controlled position upon loss of air to the positioner. 


\subsection{FAN MOTOR}

a. Motor shall be $20 \mathrm{hp}, 1200 \mathrm{rpm}$, three phase, 440 volt, 60 cycle.

b. Motor shall be manufacturex's standard, with single end shaft, conforming to the following requirements:

(1) Motor shall conform to the standards of NEMA and AIEE for ratings, performance characteristics, insulation values and mounting dimensions, with a service factor of $115 \%$.

(2) Motor shall be $55 \mathrm{C}$ rise over $40 \mathrm{C}$ ambient, continuous rating, normal torque, normal starting current, and equipped with ball bearings and dripproof frame.

(3) Motor shall be designed for grease lubrication and shall be equipped with lubrication fittings and relief plugs or openings.

(4) Motor shall be mounted on an adjustable platform welded securely to the fan housing. Platform adjustment shall provide a minimum installation and take-up allowance for belt adjustment in accordance with the belt manufacturer's recommendations.

\subsection{FAN DRIVE}

a. V-belt sheaves shall be of two-piece construction consisting of a split hub having an internal key slot and an external taper. The hub shall be split axially opposite the key slot. The hub mating surface of the sheave shall also be tapered so that, after installation, the hub will securely grip the shaft equivalent to a shrunk-on fit with no wobble between components. It shall be possible to install or remove the sheave assemblies in the field without benefit of heat or special tools and without shock to bearings or machinery. Sheave assembly shall be dynamically balanced at the manufacturer's plant to within two inch-ounces or less.

b. Belts shall be matched and shall be designed for 150 percent of driving motor horsepower rating.

c. A personnel guard, conforming with Hanford Standard M-4-6, shall be provided around the Vabelts and drive sheaves.

\subsection{FAN BASE}

a. The fan shall be isolated from the builaing floor by a vibration and sound absorbing base. 


\subsection{FAN BASE (Continued)}

b. The isolation base shall be a single unit of allowelded, steel construction.

c. The isolators shall be the spring type with the size and number as required to be capsble of 95\% damping efficiency bssed upon the disturbing frequencies for $10 \%$ above to $25 \%$ below the rated speed of the fan and the number of bisdes in the fan rotor. The isolators sh5.1i. be adjustable for leveling and lateral snubbing s.nd equipped with rubber inserts to prevent metal to metal contact.

\subsection{FINISH}

8. Profor to delivery, all foreign matexial, mill scale, oxidstion, etc.s shall be removed and metai protective primer applied to the exterior in accordance with the minufacturer's standard practice. lieaning shali zonfurm Jo SSPC-SP6.

b. All equipment shall be finished on the exterior with two coats of light gray machinery enamei. Color shall ms,tch No. 16329 of Federsi Standard No. 595.

c. Fan impellex, casing interiox, and radial inlet damper interior, shil be psinted with a prime coat of Amexcout 86 and two finish coats of Amercoat 33 , or approved equal, applied per coating manufacture $x^{3}$ ह specificstions。

12.6 PROCESS AREA VENTIIATION ZONE III EXHAUST FAN UNIT EPN 324-8900-977 (1. REQUIRED)

a. The exhaust fan unit shall be the same as specified in section $1 \pm$ above.

13. PROCESS AFEA SUPPIY - ATHTMATIO FILIFR EPN 32408900-901D (I REQITEHD)

The rentilation supply air filter shall be automatic renewable medis, dxy filtration unit.

\subsection{DESTGN AND CONSTRICTION REQUIREMENTS}

The filter shall be designed to meet the following conditions and requirement:

a. Alr temperature $40-105 \mathrm{~F}$.

b. Horizontal sir flow with a face velocity of approximately 500 fpm. 


\subsection{DESIGN AND CONSTRICTION REQULREMENTS (Contirued)}

c. 100 percent outside bir with mineral dust as the proincipsi contaminant:

d. Efficiency shall be 85 fercent by AFI Cole Weight Test.

e. Operating resistance

(1) 0.5 inches WoG. g.t rated veiocity (dixty)

(2) 0.16 inches WoG. intiey rezictance (alean)

(3) Capscity sheil be 87,000 efm winimum

f. Filter shali have the following dimenaion:

(1) Height - 15 feet oversis

(2) Width - 14 feet oversil not including the drive assembiy

(3) Unit ehall be 3 sections wide by 1 section high

(4) Iength - 4 feet maximum ineiuding spsce to sexvice unit (in direction of zirflow)。

g. Casing shail have drilied fisnges for mounting in a sheet metai ventilation supply unit casing.

h. Media shall be enclosed on the clean end to prevent accidental dirt relesse on the downstresm side vefore it enters the meila gijde.

1. The filter shall be provided with media supporte of sufficient strength to permit ladder support when replacing media.

j. Personnel guards, conforming to Hanford Standard Molto6 shail be provided arsund all Vubeits snd rotating parts。

\subsection{FIITER MENIA}

a. The filter media shsil be nominal 2-inch thick, graduated density; glass wool mat impregnated with nonflsmaib is a hesive having : dust holding capacity of 130 grains ger aquare foot at a pressure drop of 0.45 inches water gage.

b. Test dsta by an independent testing compsny shail be submitted together with cost of medis in order to evaluate filter operating coste. Test data shal. be based upon AFI dust and shal jusiuje media usage at a pressure drop ot 0.45 inch water gsge together with corresponding dust hoiding csfacity. Acceptance or rejestion of the unit may be on the basis of the test data submitied.

c. Filter rolls shall be 65 feet long. 


\subsection{FIITER LRIEES AND CONTROIS}

a. Filter control shall be 120 volt, 60 eycle grranged in NEMA Type 2 enclosure incoworeting a 48 hour cycle timer equipped with sajustable trifping devices. Medis shall ke fes a distsnce of spproxintisty $2-1 / 4$ inche esin time the drive is energized. Controls shail have a momertary contact switch for msiusil control of media advance.

b. Filter melid drotre shsil be provided and mounted outside of the gir stream and shall consist of $1 / 6$ hor sepower industrial motor and reaucion geax xated for 120 ysits, 60 cycie service which sheil drive the melis curtajn through s euitibie belt and whsting linkage. one drive motor shail be used for the entire ssembiy. The drive shill. be mosnted on the left hand side of the wnit when viewed by facing in the diretion of gir flow.

c. Iimit ewitohes and signal lights chall be provided on the control box to sudicate thst the medx has been exhausted. Ore limit Exitsh with SPDI contsets shail be poovided to alsm filter medic defietion st a remote annunciator. Meija Iimit controls shall be arranged to interrut: the automatic cycie to insure that the media cannot be removed from the filter fase except by manusil override oferation duriong filter servicing.

d. Filter control enclosure shagl ke mounted on the filter frame outside of the sir stresm.

e. All metsil surfaces exposed to the gir etream shall be of corrosion resistent givanized conerxuction.

\subsection{FINISH}

AlI ferrove $x a t$ te of the filter which are not galvanized shall be psinted with a prime coat snd two cost: of ensmel. The prime cast shali be $r \in d$ lesd aikyd base conforming to Federa srecification TT-For6a, Tyse III, and the finith catis shail be alkyd base ensmel

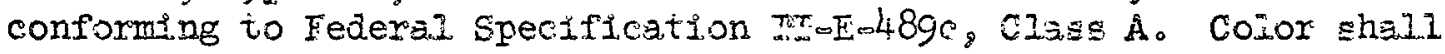
be blsick.

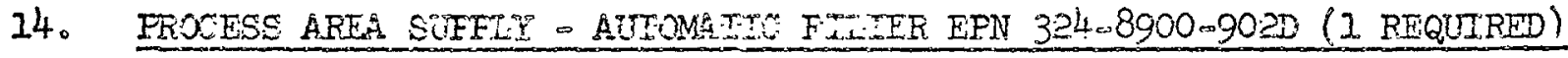

a. The ventilstion supiy sir filter shall be the same as specified under Seztoor 13 ghove.

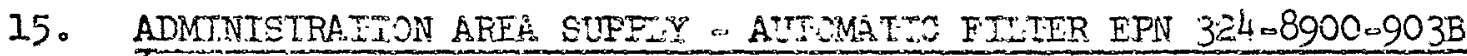
(1. REQTEIEED

The six filtex shall be the sarte $\mathrm{x}$ specified under section 13 above 
15. ADMTNISIRATION AREA SUPPI:Y - AUTOMATIC FILITER EPN 32l-8900-903B (I REQUIRED) (Continued)

with the following exceptions:

a. Capacity shali be 20,000 cfm minimum.

b. Height - 9 feet overall.

c. Wiath - 6 feet overall not including the drive assembly.

d. Unit shall be 2 sections wide by 1 section high.

16. PROCESS AREA SUPFLY AIR WASHER AND PUMP EFN 324-8900-901C (1 REQUIRED)

Zone I air washer shall be manufacturer \& standard capillary wet cell air washer of the concurrent flow type, right hand. Washer shall be American Blower Corporation, Ciass I, Unit No. 10-8, ten cells high and eight cells wide, or an approved equal, meeting the requirements stated herein.

\subsection{DESIGN AND CONSTRUCTION REQUIREMENTS}

The unit shall be designed to meet the following conditions and requirements:

a. Unit shall have a saturation efficiency of 95 percent or better.

b. Pressure drop shall not exceed 0.45 inches W.G.

c. Capacity shall be 87,000 efm minimum.

d. Piping connections shall be on the right side when viewed by facing in the direction of air flow.

e. Nozzles shall be low head ( 3 psi) and adjustable for direction.

f. Internal piping shall be galvanized steel furnished with trasher. External plping shall be sized by the manufacturer to fit the pump.

8. Overall dimensions shall be approximately $14^{\circ}$ - $I^{\prime \prime}$ high by $13^{\prime}-6^{\prime \prime}$ wide by $5^{\prime}-1^{\prime \prime}$ Iong. 


\subsection{GLASS FIBER CEITS}

8. Cells shall be approximately $20 \times 20 \times 8$ inches and shall be designed to prevent sagging of the glass media.

b. Fibers shall be oriented raraliel to the girflow.

c. Frsmes shall have galvanized wire mesh faces and equipped with lifting handles.

d. Each cell shall have an effective glass contsct area of 125 square feet.

\subsection{WASHER TANKK}

8. Tank shail be $3 / 16$ inch thick minimum all welded construction.

b. Tank shall be furnished with the following connections:

(1) Makeup connection with flost valve o $3 / 4$ "

(2) Pump suction with bronze mesh strainer - 5"

(3) Oyerflow - 3"

(4) Drain - 3"

(5) Quick FiII - $i \frac{1}{4}$

(6) Dilution - $\frac{2}{2} "$

(7) Spray Headex - $1 \frac{1}{2} "$

c. Washer tank surfaces shall receive one cost of primer and two coats of manufacturer ${ }^{\circ} s$ standard corrosion resistant paint.

\subsection{CASING}

8. Casings shall be 18 gruge (minimum) galranized steel, water tight construction.

b. Joints shali be riveted and soldered.

c. Casings shall be reinforced with two by two inch(minimum) galvanized steel angles.

d. Casings shall have external supporting members and flangeduanddrilled end connections.

\subsection{ELIMINTAIORS}

a. Eliminators shall be 24 gauge (minimum) gaivanized steel snd shall have a minimum of three surfaces and two hooks. 


\subsection{ELIMINATORS (Continued)}

b. Recommended surfaces to be at a 45 degree angle with $2 \frac{1}{2}$-inch spacing.

c. Elimingtors shall be resily removable from the washer.

\subsection{PUMP}

a. Pump shall be single stage, eingle suction, centrifugal tyce with horizontal split casing.

b. Capacity shall be 240 gom at 35 feet head.

c. Pump shall have bronze impelier, renewable bronze wearing rings, a.loy steel shaft, bronze shaft sleeves and cast iron case。

d. Pump motor shall be manufacturer's standard with single end shaft conforming to the following requirements:

(1) Motor shall be 440 volt, 60 eycle, 3 phase and shall conform to the standards of NEMA and ATEE for ratings, performance charactexistice, insulation values and mounting dimensions, with a service factor of $115 \%$.

(2) Motor shall be $55 \mathrm{C}$ rise over $40 \mathrm{C}$ ambient, continuous rating, normal torque, normal starting current, and equipped with ball bearings and drip proof frame.

(3) Motor shall be designed for grease Iubrication and shall be equipped with lubricstion fittings and relief plugs or openings.

e. Personnel guards, conforming with Hanford Standard M-4-6, sha.1I be provided over or arourd all exposed shafts and couplings.

17. PROCESS AREA SUPPIY AIR WASHER AND PUMP EFN 324-8900-902C (I PEQIIRED)

a. The air washer and pump shall be the same as specified under Section 16 above.

18. PROSESS AREA PREHEAT COIL EEN 324.08900-901E (I REQUIRED)

a. Freheat coil shail raise the temperature of 80,000 scfm of air from minus $10 \mathrm{~F}$ to plus $65 \mathrm{~F}$ when operating with 100 psig steam. 
18. PROCESS AREA FFEHEAT COII EEN 324-8900-901E (1 REQUIRED) (Continued)

b. Coil section shall consist of two I.J. Wing Mfg. Co. IFB Heater Sections Size 40.C (top row), and two L.J.Wing Mfg。Co. IFB Heater Sections Size 44 (bottom row), or approved equal, in accordance with the reguirements stated below.

c. Each heater section shall consist of builtoin multiple alternating finned hesing elements and byopasses with interlocked dampers, controlied by preumatic damper motor and air stream thermostat. Heaters whal be capable of maintainirg a constant discharge air temperature regardiess of variations of entering air temperature with full steam pressure on the coil at all times.

d. Proportioning of the air stall be such that the average temperature at any point in a piane parallel to the face of the heater three feet downstream of the leaving side will not rary more than $5 \mathrm{~F}$ from the thermostat setting.

c. Finned heating elements shall be fabricated of seamless return bend type copper tubes with rectangular aluminum fins spsced not closer than $7 \frac{1}{2}$ fins per inch. Each tube shail be individualiy secured to the steam and return headers by a mechanical joint consisting of s nut and ferrule compression union, to allow for individual remoral of tubes in the event of damage. Mubes shail be secured against vibretion by a chsnnel-shaped retainer permitting expansion and contraction. Finned element s shall be factory tested at 200 psig steam and 1000 psig hydrostatic pressure.

f. Pressure drop of air paseing through the section shall not vary more than pius or minus $5 \%$ regardless of the position of the internsi dampers.

g. Each heater section shali be equipped with a properly installed pneumatic damper motor, or motors as required, to be designed for use with 3-15 psig control instrument eir. Since the ends of the two heater sections making up the tor row will be instalied with the ends butted together, the damper lialsage and motox location of one section shall be right hard and the damper linkage and motor location of the other section shall be left hand. The above also applies to the bottom row of hester sections.

19. FROCESS AFEA PREHEAT COII EFN 324.08900-902E (1. FEQUIRED)

The preheat coil shall be the same as specified under section 18 sicove. 
20. ADMINISTRA TION AREA FREHEAT COIL EPN 324-8900-903C (1 REQUIRED)

The preheat coil shall be the same as specified under Section 18 above with the following exceptions:

a. Preheat coil shall raise the temperature of 3,000 scfm of air from minus $10 \mathrm{~F}$ to plus $75 \mathrm{~F}$ when operating with 100 psig steam.

b. Coil section shali consist of one I. J. Wing Mfg. Co. IFB Heater Section Size 2506, or approved equal.

21. PROCESS AREA REHEAT COII EPN 324-8300-901B (1 REQUIRED)

a. Reheat coil shall raise the temperature of 80,000 scfm of air from plus $45 \mathrm{~F}$ to plus $65 \mathrm{~F}$ when opersting with 8 psig stesm.

b. Coil section shall consist of eight coils arranged two coils wide by four coils high. Nominal casing dimensions of each coil shall be $6^{\circ}$ - 8" long by $33^{\prime \prime}$ wide. Each coil shall have a minimum fase area of 14.7 square feet.

c. Coils shall have 5/8 inch O.D. copper tubes with copper fins。

d. Fins shall be bonded to the tubes by a solder dip or mechanical expansion of the tube.

e. Colla shall have non-ferrous ateam distribution inner tubes.

f. Supply and return headers shail be welded steel or cast semi-steel formed into a single header and shall be on the same end of the coil.

g. Casing shall be designed to permit free expansion of the header: and tubes.

h. Trubes shall be pitched within the casing to provide drainage.

1. Casing shall have drilied flanges.

j. Casing shall be 16 gauge steel (minimum), galvanized.

k. Coils shall be designed for continuous opergtion at 100 psig steam pressure.

1. Coils shall be Aerofin Corp. Tyre $B_{\text {, }}$ or approved equal. 
22. PROCESS AREA REHEAT COIL EPN 324-8900-902B (I REQUIRED)

The reheat coil shall be the same as specified under section 21 .

23. ZONE REHEAT COIIS (EP NUMBERS AS TABULATED - I REQUIRED EACH EPN)

a. Reheat coil sections shall raise the specified air flow from $65 \mathrm{~F}$ to the final temperatures as listed in the tabular coil data of this section when operating with 8 psig steam.

b. Each coil section shall be one coil wide with the height being dictated by the number of coils listed.

c. Coils shall have 5/8 inch $0 . D$. copper tubes with copper fins.

d. Fins shall be bonded to the tubes by a solder dip or mechanical expansion of the tube.

e. Colls shall have non-ferrous steam distribution inner tubes.

f. Supply and return headers shall be welded eteel or cast semisteel formed into a single header and shall be on the same end of the coil.

g. Casing shall be designed to permit free expansion of the headers and tubes.

h. Tubes shall be pitched within the casing to provide drainage.

i. Casing shall have drilled flanges.

j. Casing shall be 16 gauge steel (minimum), galvanized.

k. Coils shall be designed for continuous operation at 100 psig steam pressure.

1. Coils shall conform to the following tabular data:

\begin{tabular}{|c|c|c|c|c|c|}
\hline COII SECTION & AIR FLOW & FINAI AIR & COIISS PER & INDIVIDJAI, $C$ & II IAI: \\
\hline EPN & CFM & TEMP F & SECIION & NOMINAL DIM。 & $A P=A==E$ \\
\hline $324-8900-904$ & 3,075 & 90 & 1 & $3^{\prime}-8^{\prime \prime} \times 24^{\prime \prime}$ & 5.2 \\
\hline $324-8900-905$ & 4,625 & 80 & 1 & $4^{\prime}-2^{\prime \prime} \times 29^{\prime \prime}$ & \\
\hline $324-8900-906$ & 4,350 & 90 & 1 & $4^{\prime}-2^{\prime \prime} \times 29^{\prime \prime}$ & 7.4 \\
\hline $324-8900-907$ & 4,150 & 85 & 1 & $4^{\prime}-8^{\prime \prime} \times 24^{\prime \prime}$ & 7.0 \\
\hline $324-8900-908$ & 2,600 & 80 & 1 & $3^{\prime}-8^{\prime \prime} \times 24^{\prime \prime}$ & 5.2 \\
\hline $324-8900-909$ & 18,750 & 80 & 2 & $6^{\prime}-8^{\prime \prime} \times 33^{\prime \prime}$ & 14.7 \\
\hline
\end{tabular}

1 $130-\quad$ HWS -5967 
23. ZONE REHEAT COIIS (EP NUMBERS AS TABULATED - 1 REQUIRED EACH EFN)

1. (Continued)

\begin{tabular}{|c|c|c|c|c|c|}
\hline $\begin{array}{c}\text { COII SECTION } \\
\text { EPN } \\
\end{array}$ & $\begin{array}{l}\text { AIR FLOW } \\
\text { CFM }\end{array}$ & $\begin{array}{l}\text { FINAL AIR } \\
\text { TEMP F }\end{array}$ & $\begin{array}{c}\text { COIISS PER } \\
\text { SECTION } \\
\end{array}$ & $\begin{array}{l}\text { INDIVIDUAL C } \\
\text { NOMINAL DIM. }\end{array}$ & $\begin{array}{l}\text { II. DATAA } \\
\text { AFEA FI? }\end{array}$ \\
\hline $\begin{array}{l}324-8900-910 \\
324-8900-911 \\
324-8900-912 \\
324-8900-913 \\
324-8900-914 \\
324-8900-915 \\
324-8900-916 \\
324-8900-917 \\
324-8900-918 \\
324-8900-919\end{array}$ & $\begin{array}{r}19,350 \\
9,000 \\
22,855 \\
11,045 \\
17,500 \\
6,750 \\
11,900 \\
6,900 \\
22,800 \\
6,850\end{array}$ & $\begin{array}{l}80 \\
85 \\
80 \\
75 \\
85 \\
80 \\
75 \\
85 \\
85 \\
75\end{array}$ & $\begin{array}{l}2 \\
1 \\
2 \\
1 \\
2 \\
1 \\
2 \\
1 \\
2 \\
1\end{array}$ & $\begin{array}{lll}6^{\circ}-8^{\prime \prime} & x & 33^{\prime \prime} \\
6^{\circ}-8^{\prime \prime} & x & 33^{\prime \prime} \\
7^{\circ}-2^{\prime \prime} & x & 33^{\prime \prime} \\
6^{\circ}-8^{\prime \prime} & x & 37^{\prime \prime} \\
6^{\circ}-8^{\prime \prime} & x & 33^{\prime \prime} \\
6^{\circ}-8^{\prime \prime} & x & 29^{\prime \prime} \\
5^{\circ}-8^{\prime \prime} & x & 29^{\prime \prime} \\
5^{\circ}-8^{\prime \prime} & x & 33^{\prime \prime} \\
6^{\circ}-8^{\prime \prime} & x & 37^{\prime \prime} \\
5^{\prime}-2^{\prime \prime} & x & 33^{\prime \prime}\end{array}$ & $\begin{array}{l}14.7 \\
14.7 \\
15.9 \\
16.8 \\
14.7 \\
12.6 \\
10.5 \\
12.2 \\
16.8 \\
11.0\end{array}$ \\
\hline
\end{tabular}

m. Coils shall be Aerofin Corp, Type $B_{8}$ or approved equal.

24. ADNINISTRAIION AREA CHILIED WATER COII EPN 324.08900-903A (1 REQUIRED)

a. Cooling coil shall lower the temperature of 18,800 scfm of air from plus $82 \mathrm{~F}$ to plus $60 \mathrm{~F}$. Air flow will be horizontal. Cooling media will be an ethylene glycol water mixture ( $34 \%$ ethylene glycol by weight at $44 \mathrm{~F}$ ). The chilled water will enter the coil at $44 \mathrm{~F}$ and shall exit at $54 \mathrm{~F}$ 。

b. Coil section shall consist of three coils arranged one coil wide by three coils high. Nominal casing dimensions of each coil shall be 6"- 4" long by 29" wide. Each coil shall have a minimum face ares of 12.4 square feet.

c. Coils shall have $5 / 8$ inch $O . D$. copper tubes with copper fins。

d. Fins shall be bonded to the tubes by a solder dip or mechanical expansion of the tube.

e. Supply and return headers shall be steel or copper and shali be on the same end of the coil.

f. Drain and venting connections shall be provided.

g. Casing shall have drilled flanges.

h. Casing shall be 16 gauge steel (minimun), galvanized. 
24. ADMINISTRATION AREA CHIJUED WATER COII EPN 324-8900-903A. (I REQUIRED) (Continued)

i. Coils shall be designed for a working pressure of 200 psig.

j. Coils shall be Aerofin Corporation Type $C$, or approved equal.

25. PACKAGED WATER CHIIIER EPN 324.8900.903F (I REQITRED)

The water chiller shall be a factorymassembled, packaged unit complete with all necessary refrigerant piping, refrigerant flow controls, water flow controls, and electrical wiring furnished and installed by the manufacturer. The unit may contain a single set or identical multipie sets of compressors and condensers assembled in a rigid frame with $\approx$ single direct expansion chiller. Unit shall conform to AüA By.L

\subsection{CAPACITY}

a. The unit shall have a capacity of not less than 37.5 tons of refxigeration when cooling 92 GPM of ethylene glycol water ( $34 \%$ ethylene glycol by weight at $44 \mathrm{~F}$ ) solution from an entering temperature of $54 \mathrm{~F}$ to a leaving temperature of $44 \mathrm{~F}$ when the condenser is supplied with water st $70 \mathrm{~F}$.

b. The overall heat transfer coefficient for the condenser (or condensers) shall be based on 0.003 fouling factor while the hes: transfer coefficient for the chiller shali be based on 0.0005 fouling factor.

\subsection{COMPRESSOR}

Design of the compressor is optional as to Hermetic, Openmirest drive, or Openabelt drive.

a. Hermetic (single or multiple) type shall be as specified below:

(1) The compressor shall be a reciprocating motor-compressor with an integrally cast crankcase and cylinder block of the serviceable hermetic type.

(2) The compressor shali be force-feed Iubricated through 3 fuilflow oil filter with a positive feed oil pump.

(3) The compressor shall, have suction strainer, crankcsse heater, suction and discharge shutoff valves and oil level sight glass, 


\subsection{COMPRESSOR}

a. (Continued)

(4) The compressor motor shall be cooled by the suction gas passing around the windings, and shall have thermal protection against unusual high temperature conditions. The motor shall operate on 440 volts, 3 phase, 60 cycle power service at $1750 \mathrm{rpm}$.

b. Open direct drive or Openmbelt drive (single or multiple) compressor shall be as follows:

(1) The compressor shall be of the reciprocating type driven either through a coupling (direct) or through vee beits. The drive shall be encased in $a$ guard.

(2) It shall be force feed lubricated through a fulloflow oil filter with a positive feed oil pump.

(3) The compressor shall have suction strainer, crankcase heater, suction and discharge shutoff valves and oil level sight glass。

(4) The motor shall operate on 440 volts, 3 phase, 60 cycle power service at $1750 \mathrm{rpm}$. Motor shall conform to the standards of NEMA and AIEE for rating, performance characteristics, insulation values, and mounting dimensions with a service factor of 115\%。 Motor shall be $55 \mathrm{C}$ rise over $40 \mathrm{C}$ ambient, continuous rating, normal torque, normal starting current, and equipped with ball bearings and dxip proof frame.

\subsection{CONDENSER}

The condenser shail be of the shell and tube type constructed in accordance with the ASME Code for Unfired Fressure Vessels and is to be inspected and stamped accoringly.

\subsection{CHIIIER}

a. The chillex shall be of the multi-pass shell and tube type con structed in accordance with the ASME Code for Unfired Fressure Vessels and is to be inspected and stamped accordingly.

b. The chiller shall be completely insulated with a, two inch (minimum) layer of fibrous glass insulation with a vapor barriex. 


\subsection{REGRIGERANF AND PIPING}

a. Unit shall use Refrigerant 22 and shall be shipped from the factory with a holding charge of refrigerant and chaiging valve.

b. All suction lines shall be insulated with close fitting cellular insulation.

c. Iiquid lines fhall include a sight glass liquid mojsture indicator, controlled soleroid yalve

d. High and low pressure gages shsil be factory instalied in the control panel.

\subsection{ELECTRICAI DEVICES AND CONIFOLS}

a. Unit shall be equipped for operation on 440 volt, 3 phase, 60 cycle power supply. A transformer shall be included for reducing control. equipment voltage to 110 volts.

b. Electrical wiring and controls installed at the fretory inifinclude circuit breakers for a.11 branch circuit protection starter (s) with motor protection devices, chilied water manusi reset safety thermo. stat, high and low pressure switches, condenser water reguisting valve, crankcase heater (E), and suction, discharge and oil fressure gages. Provicion shall be made for connecting an interlock contact from the chilied water pump motor starter into the refrigexator controls. The automatic control systen, starter, etcos shall be installed in an enclosed control panel mounted on the unit. The pressure gauges shall be mounted on the front of the psnel.

c. Unit shall have at lesst three steps of capacity redustion.

\subsection{VIBRATION ISOLATION MOUNIINGS}

The unit shall be isolated from the building floor by spring type isolators with the size and number $3 s$ required to be capable of $95 \%$ damping efficiency. The isolators shall be adjustable for leveling and lateral snubbing and be equipged with rubber inserts to prevent metal to metai contsct.

\subsection{GIARDS}

a. Personnel guards, conforming with Hanford Standard M-406 shii: be provided over or around a.1I exposed Vobelts, shafts, and couplings. 
25.9 FINISH

a. Prior to delivery, Ell foreign material, mill scale, oxidation, etc., shali be removed and a primer applied in accordanee with the monufacturer ${ }^{2} \mathrm{~s}$ standsra proctice.

b. Ali equipment shall be finished with light gray machinery enamel. Color shail match No. 16329 of Federal standard No. 595.

26. CHILTEL WATEE FUMP EPN 324.8900.903G ( 1 REQTIRED)

a. Chilled water circulating pump shall be of the horizontal, centrifugal type closewoupled to the motor.

b. Pump shali have cast iron casing, bronze impeller, end suction, rertical jischarge, and mechanical seal euitable for ethylene. glycol water solution service.

c. The pump shall have a rating of 92 GPM of ethylene-glycol water ( $34 \%$ ethylene glycol by weight at $44 \mathrm{~F}$ ) solution at 35 feet $\mathrm{IDH}$ (minimum).

d. The motor shall operate on 440 volts 3 phase, 60 cycle power service at $1750 \mathrm{rpm}$. Motor shall conform to the standards of NEMA and AIEF for rating, performance chsracteristics, insulation valves, and mounting dimensions with a service factor of $115 \%$ Motor shali be $55 \mathrm{C}$ rise over $40 \mathrm{C}$ ambient, continuous rating, normil torque, normal starting current, and equipped with bali kearings and. dripproof frame.

e. The pump and motor shall be mounted on a common base plate.

f. The fump, motor, and base piate shali be shop finished with light gray machirery ensmel. Coior shall matwh No。 I6329 of Feder Standard No. 595.

27. EIECIRIC DUCI HEATER EPN 324-8900-920 (1 REQUIREE)

Q. Electric duct hester shali have a cepacity of 2,000 watt heating $775 \mathrm{cfm}$ of air and shall operate on 220 volts single phsse, 60 cycie power service.

b. Duct dimensions are 16 inches wide by 12 inches high with the duct being flanged at the rester.

c. Heater shall have longltudinal fins with stginless steel shezths. 
27. EIECIRIC DUCI HEATER EFN 32/48900-920 (1 REQUIRED) (Continued)

d. Heater shall be equipred with thermal cutoouts of the reset type to protect elements from overtemferature in case of stoppage of air circulstion.

e. Heater shall be furnished complete with a rigid, heavy 16 gauge steel frame, with manufacture $x^{2} s$ standara finish and a completely enclosed termingi block.

28. STEAM UNIT HEAIEF EPN 324-8900-925 (I FEQULRED)

a. The verticaiothrow, propeiler fsn, tyce unit heater shail conform to Air Moving and Conditioning Association Ine. Standards.

b. Unit shall hsve a capacity of 220,000 btu per hour on the basis of $60 \mathrm{~F}$ entering sir and 100 psig steam.

c. The coil shall be of the extended surface tyce and shall have the following features.

(1) Fins shall be bonded to the tube by soldering or mesharifcal expansion of the tube.

(2) Coil shail be supported in the casing to permit expansion and contraction of the coil.

(3) Coil shall be designed ari guaranteed to withstand all steam pressures and temperatures up to 200 psig saturated.

d. The cssing shall consist of two circular plates of 18 gauge steel (minimum) between which a circular extended surface coil shal: be fastened forming the unit. The lower plate shill form the orifice for delivery of the heated alr. The top plate shall be provided with a speciel ring cup to movnt the motor sway from the col I. Motox mounting brackets and thresded connections for fastening hanger rois shal be provded on the top plate.

e. The fan tades shail be proferiy located in a venturiatype shroud to obtain maximum ferformsnce. Fan shall be connected darectiy to the motox shsft. Fan sfeed shili not exceed $1200 \mathrm{rpm}$. Fan shali be properly balanced to eliminate vibritz on and noise.

f. The motor shall conform to the standards of NEMA and AIEF for rat Ing, performince characteristics. insulation vilues and mounting dimensions, with a servace fist 30 of 175\%. Motor shall be specificaliy designed for continuous dity on propelier fsn appiicstions. 
28. STEAM UNIT HEATER EPN 324-8900-926 ( 1 REQUIRED)

f. (Continued)

Motor shall have ball bearings and shall be enclosed in an open dripproof enclosure. Rating shall be for continuous operation, normal torque and stariing current. Motor shall be mounted so that aix at room temperature is drawn over the motor while the fan is in operation, and shielded from the heating element to prevent overheating when the fan is not in operation. Motor shall operate on single phase, 120 volt, 60 cycle power.

g. The unit heater casing shall be finished with light gray machinery enamel. Color shall match No. 16329 of Federal Standard No. 595.

29. ELECTRIC UNIT HEATER EPN 324-8900-927 (1 REQIJIRED)

a. The horizontal whrow, propeller fan type, electric unit heater shal I be designed for suspended mounting.

b. Unit shall have a capacity of 7.5 lilowstts operating on 480 vits 3 phase, 60 cycle power suppiy.

c. Heating elements shall be either of the tubular type with radiating fins, or of the finned element type.

d. Overheating protection shall be provided by automatically operating thermostatic cutouts.

e. The casing shall be 18 gauge steel (minimum). A shroud shall be provided around the motor to protect it from being overhested by the heating element. Air at room temperature shall be drawn past. the motor when it is in operation.

f. Fan blades shall be properly located in a venturi-type shroud to obtain maximum performance. Fan shall be connected directiy to the motor shaft. Fan speed shell not exceed $1200 \mathrm{rpm}$. Fan shail be properly balanced to eliminate vibration and noise.

B. Motor shall conform to the standards of NEMA and AIEE for rating, performance characteristios, insulation values and mounting dimensions, and shali hove a service factor of 115\%. Motor shall be specifically designed for continuous duty on propelier fan applications. The motor shall have ball bearings and shall be enclosed in an open dripproof enclosure. Rating shall be for continuous operation, normal torque and starting current. Motor shall be mounted so that air at room temperature is drawn over the motor while the fan IE in operation. Motor shall operate on single phase, 120 volt, 60 cycle power. 
29. ELECTRIC UNIT HEATER EPN 324-8900-927 (1 REQUTRED) (Continued)

$h$. The unit heater casing shall be finished with light gray machinery enamel. Color shall match No. 16329 of Federal standard No. 595.

30. ELECIRIC UNIT HEATER EPN 324-8900-928 (1 REQUIRED)

The unit heater shall be the same as specified under section 30 except as follows:

a. Heater shall be of the vertical othrow propeller fan type.

b. Unit shail have a capacity of 5 kilowatts operating on 480 volt,

31. MULTI-BLADE CONTROI DAMFERS AND OFERATORS (EP NUMBERS AS TABUTATED)

a. Damper sizes shall be as shown on the drawings.

b. Damper construction shall be as follows except where noted otherwize:

(1) Blades: 16 gauge galvanized steel with interlocking elges。

(2) Blade length: 48 inches (maximum) reinforced for lengths in excess of 36 inches.

(3) Blade wiath: 4 inches minimum, 10 inches maximum.

(4) Blade shafts: $\frac{1}{2}$ inch diameter by 6 inch length minimum.

(5) Bearings: oil impregnated bronze (stainiess steel where noted) sleeve except for extencion shafts for connection to operators or locking quadrants which shall be ball bearings.

(6) Frame: flanged channez construction of black steel for installation between ms,ing flanges, 12 gauge minimum, manufacturer ${ }^{2} s$ standard painted finish.

(7) Braces: corner braces shsil be provided on dampers over 16 inches in any dimension.

(8) Stops: all damper sections shall be provided with continuous angle end stops and flat bsr side stops.

(9) Sections: dampere with blsdes over 48 inches long shali be made in two or more sections.

c. Manual damper regulators shell be similar to Minneapolis Honeyuei工 Company hand quadrants, or approved equal, for dampers under 15 square feet in area.

(1) Quadrant No. WDI017 shall be used for dampers up to 6 square feet in area.

(2) Quadrant No. $303361 \mathrm{~A}$ shali be used for dampers over 6 square feet and under 15 square feet in area. 
31. MULTI-BLADE CONIROI DAMPERS AND OPERATORS (EP NUMBERS AS TABULATED) (Continued)

d. Damper regulators similar to Young Regulator Company series 900, or approved equal shall be used for dampers larger than 15 square feet in area.

e. Pneumatic Damper Operators-oType $I_{8}$ shall be as follows:

(1) Damper operator shall be sized to provide at least $120 \%$ of damper torque requirements at design conditions. Number and size of operators is optional.

(2) Operator shall be of the air-orerated, spring-return modulating type with pilot positioner.

(3) Pilot positioner shail be mounted directly on damper operator and shall be supplied trith gauge and by-pass manifoid.

(4) Control air pressure for the positioner is at 3-15 psig while 40 psig air is available for the damper operator.

(5) Damper operator shall be suprified with a diaphragm seal to prevent leakage. Adjustable stops shaIl be provided to adjust length of stroke.

(6) Operator shall be mounted externally on the damper frame wniess noted otherwise.

f. Pneumatic Damper Operators--Iype II, shall be as follows:

(1) Damper operator shall be sized to provide at least $120 \%$ of damper torque requirements at design conditions. There shall be no more than one operator used for each damper.

(2) Operator shall be of the bsianced, air-operated, modurating type with pilot positioner and visual indicator covering fuII range of travel.

(3) Pilot positioner shali be mounted directly on damper operetor and shall be suppifed with gauge and by-pass manifold.

(4) Control air pressure for the rositioner is at 3-15 psig while 40 psig air is available for the damper operator.

(5) Adjustable stops shall be provided to adjust length of ejujke.

(6) Operator will be mounted remotely from the damper as zhown or. the drawings. Operator action will be transmitted to the dimper through an armored fiexible shaft to be supplied with the jsmier and operator in accordance with the foliowing flexible shaft specifications:

(a) Operation load shall be transmitted through a stsinless steel center blade supported along its full length by precision ball bearings spaced at close intervals. 
31. MULTI-BIADE CONTROL DAMPERS AND OPERATORS (EP NUMBERS AS TABUIATED)

f. (Continued)

(b) The center blade shall be located between two stainless steel outer blades with the ball bearings occupying the intervening space.

(c) Both the inner and the outer blades shall be grooved along their entire lengths to locate the ball bearings longitudinally.

(d) The ball bearings shall be cased in perforated stainless steel strip cages which keep them correctly spaced.

(e) The complete assembly comprising the inner blade, the outer blades, the ball bearings and cages, shall be housed within a flexible stainless steel tube of interlocked construction.

(f) Tension and compression ratings shall be at least $150 \%$ of damper operator maximum force capabilities at the available air pressure listed.

(g) Backlash shall be negligible.

(h) Efficiency shall be between $75 \%$ and $90 \%$. No-logd friction shall not exceed $I \frac{1}{2}$ ounces per foot of length.

(i) End fittings shall be as required to match the damper and operator connections.

(j) The outer end fittings shall be securely clamped to the operator support frame and to the damper frame in accordance with the manufacture 's instructions.

(k) Flexible shaft shall be Controlex Corporation of America, or approved equal.

g. Pneumatic Damper Operators--Type III, shall be as follows:

(1) Air-operated, spring-return, two-position.

(2) Control air pressure: $3-15$ psig.

h. Multi-louver control dampers and operators shall be in accordance with this section and the following data sheet. 
MULTI-LOUVER CONIROL DAMPER DATA

\begin{tabular}{|c|c|c|c|c|c|c|c|c|}
\hline $\begin{array}{c}\text { EPN } \\
(324-8900-\quad)\end{array}$ & $\begin{array}{l}\text { NO: } \\
\text { REQ'D }\end{array}$ & $\begin{array}{l}\text { BLADE } \\
\text { ACTION }\end{array}$ & $\begin{array}{l}\text { DAMPER } \\
\text { PIANE }\end{array}$ & $\begin{array}{l}\text { BLADE } \\
\text { AXIS }\end{array}$ & $\begin{array}{c}\Delta P \\
\left(I N \cdot W_{0} G_{0}\right) \\
\end{array}$ & $\begin{array}{c}\text { TYPE } \\
\text { OPERATOR } \\
\end{array}$ & $\begin{array}{l}\text { FAIHFD } \\
\text { POSITION }\end{array}$ & REMARKS \\
\hline $903-D$ & 1 & Opposed & Vert. & Hor. & - & Manual & $=$ & - \\
\hline $903-E$ & 1 & Opposed & Hor. & Hor. & - & Manual & - & $\begin{array}{l}\text { Blade axtis perpendicular } \\
\text { shortest dimension }\end{array}$ \\
\hline 945 & $\begin{array}{l}\text { As } \\
\text { Req'd }\end{array}$ & Opposed & Vert. & $\begin{array}{l}\text { See } \\
\text { Remarks }\end{array}$ & - & Manual & - & $\begin{array}{l}\text { Blade axis designed to provide } \\
\text { most accessible quadrant } \\
\text { location }\end{array}$ \\
\hline 954 & $\underset{\text { Req'd }}{\text { As }}$ & Opposed & Hor. & $\begin{array}{l}\text { See } \\
\text { Remarks }\end{array}$ & - & Manual & - & $\begin{array}{l}\text { Blade axis designed to provide } \\
\text { most accessible quadrant } \\
\text { location }\end{array}$ \\
\hline 953-AI & 1 & Opposed & Vert. & Hor. & 4 & $I$ & Open & - \\
\hline 953-AI & 1 & Opposed & Hor. & Hor. & 4 & $I$ & Open & $\begin{array}{l}\text { Blade axis perpendicular } \\
\text { shortest dimension }\end{array}$ \\
\hline $953-F$ & 2 & Opposed & Vert. & Hor. & 4 & $I$ & Open & - \\
\hline $953-\mathrm{P}$ & 2 & Opposed & Hor. & Hor. & 4 & $I$ & Open & $\begin{array}{l}\text { Blade axis perpendicular } \\
\text { shortest dimension }\end{array}$ \\
\hline $956-1$ & 1 & Opposed & Hor. & Hor. & - & III & Closed & $\begin{array}{l}\text { Blade axis perpendicular } \\
\text { shortest dimension }\end{array}$ \\
\hline $956-1$ & 1 & Opposed & Vert. & Hor. & - & III & Closed & - \\
\hline $956-2$ & 3 & Opposed & Vert. & Hor. & - & III & Closed & - \\
\hline $956-3$ & 2 & Opposed & Vert. & Hor. & 0 & III & Closed & - \\
\hline 956.4 & 1 & Opposed & Hor. & Hor. & - & $I$ & Open & $\begin{array}{l}\text { Blade axds perpendicular } \\
\text { longest dimension }\end{array}$ \\
\hline
\end{tabular}


MULTI-LOUVER CONIROL DAMPER DATA (ContInued

\begin{tabular}{|c|c|c|c|c|c|c|c|c|}
\hline $\begin{array}{c}\text { EFN } \\
(324-8900-\end{array}$ & NO. & $\begin{array}{l}\text { BLADE } \\
\text { ACIIION }\end{array}$ & $\begin{array}{l}\text { DANPER } \\
\text { PLANE }\end{array}$ & $\begin{array}{l}\text { BLADE } \\
\text { AXYS }\end{array}$ & $\begin{array}{c}\Delta P \\
\left(I N \circ W_{0} G_{0}\right) \\
\end{array}$ & $\begin{array}{c}\text { TYPE } \\
\text { OPERATOR }\end{array}$ & $\begin{array}{l}\text { FAITIED } \\
\text { POSTIRTON }\end{array}$ & REMARKS \\
\hline 956.5 & 3 & Opposed & Vert. & Hor. & 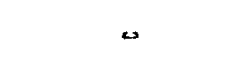 & III. & Closed & - \\
\hline $956-6$ & 1 & upposed & vert. & Hor. & 0 & IIT & Closed & $=$ \\
\hline 956.7 & 1 & Opposed & Vert:。 & Hor. & - & $I$ & Open & o \\
\hline 956.8 & 1 & Opposed & Vert. & Hor。 & - & $I$ & Open & - \\
\hline 956.9 & 1 & Opposed & Vert. & Vert. & $=$ & $I$ & Open & $\infty$ \\
\hline 956.10 & 1 & Opposed & Hor. & Hor。 & - & $I$ & Open & $\begin{array}{l}\text { Blade axis perpendicular } \\
\text { longest dimension }\end{array}$ \\
\hline $956-1.1$ & 2 & Farellel & Hor。 & Hor。 & 0 & III & Open & $\begin{array}{l}\text { Blade axis perpendicular } \\
\text { longest demper dimension }\end{array}$ \\
\hline $957 \cdot \mathrm{SG}$ & 1 & Opposed & Vert。 & Hor. & - & $I I I$ & Open & $\begin{array}{l}\text { Blades shall not protrude } \\
\text { beyond frame when wide open }\end{array}$ \\
\hline 957-AI-1 & 1 & Opposed & Vert。 & Hor. & 4 & II & Open & S. St. Construction \\
\hline $957 \sim A I-2$ & 1 & Opposed & Hor. & Hor. & 4 & II & Open & $\begin{array}{l}\text { S. St. Construction. Blade } \\
\text { axis perpendicular shortest } \\
\text { damper dimension. }\end{array}$ \\
\hline $957-H B=1$ & 1 & Opposed & Vert。 & Hor。 & 4 & II & Open & S. St. Construction \\
\hline $957-\mathrm{HB}-2$ & 1 & Opposed & Hor. & Hor. & 4 & II & Open & $\begin{array}{l}\text { S. St. Construction. Blade } \\
\text { axis perpendicular shortest } \\
\text { damper dimension. }\end{array}$ \\
\hline 1957-1 & 1 & Opposed & Vert. & Hor. & 4 & II & Open & S. St. Construction \\
\hline
\end{tabular}


MULTI-IOUVER CONIROI DAMPER DATA (Continued)

\begin{tabular}{|c|c|c|c|c|c|c|c|c|}
\hline $\begin{array}{c}E P N \\
(32.4-8900=\end{array}$ & $\begin{array}{c}\text { NO. } \\
\text { REQ'D }\end{array}$ & $\begin{array}{l}\text { BLADE } \\
\text { ACJION }\end{array}$ & $\begin{array}{l}\text { DAMPER } \\
\text { PLANE } \\
\end{array}$ & $\begin{array}{l}\text { BLADE } \\
\text { AXIS } \\
\end{array}$ & $\begin{array}{c}\Delta P \\
\left(I N, W_{0} G_{0}\right) \\
\end{array}$ & $\begin{array}{c}\text { TYPE } \\
\text { OPERATOR } \\
\end{array}$ & $\begin{array}{l}\text { FAILED } \\
\text { POSIIION }\end{array}$ & REMARKS \\
\hline $957-L B-2$ & 1 & Opposed & Hor. & Hor. & 4 & II & Open & $\begin{array}{l}\text { S. St. Constmuction. Blade } \\
\text { axis perpendicular shortest } \\
\text { damper dimension }\end{array}$ \\
\hline $957-M-1$ & 1 & Opposed & Vert. & Hor. & 4 & II & Open & S. St. Construction \\
\hline $957-M-2$ & 1 & Opposed & Hor. & Hor. & 4 & $I I$ & Open & $\begin{array}{l}\text { S. St. Construction. Blade } \\
\text { axis perpendicular shortest } \\
\text { damper dimension }\end{array}$ \\
\hline $957-P-1$ & 1 & Opposed & Vert. & Hor。 & 4 & II & Open & S. St. Construction \\
\hline $957-P=2$ & 1 & Opposed & Hor. & Hor. & 4 & II & Open & $\begin{array}{l}\text { S. St. Construction. Blade } \\
\text { axis perpendicular shortest } \\
\text { dumper dimension }\end{array}$ \\
\hline $959-1$ & 4 & Parallel & Vert。 & Hor. & 8 & Manual & - & $\begin{array}{l}\text { Carbon steel construction- } \\
\text { paint with zinc chromate } \\
\text { primer. S. St. bearings.* }\end{array}$ \\
\hline $959 \cdot 2$ & 4 & Parallel & Vert. & Hor. & 12 & Manual & - & $\begin{array}{l}\text { Carbon steel construction- } \\
\text { paint with zinc chromate } \\
\text { primer.s. St. bearings.* }\end{array}$ \\
\hline $959-3$ & 2 & Parallel & Vert. & Hor 。 & 12 & III & Open & $\begin{array}{l}\text { Carbon steel construction- } \\
\text { paint with. zinc chromate } \\
\text { primer. S. St。 bearings. } \\
\text { Intermally mounted operator.* }\end{array}$ \\
\hline
\end{tabular}

* Provide 2 limit switches and mounting brackets (downgtream side) per damper with a switch being located at each end of travel. Limit switches shall be 120 volt, AC, 60 cycle, 2 amperes rating, SPST, normally open. NOTE: "s. St:" j.r.zicates stainless steel. 
a. Fire dampers shall be Underwriters approved, vertical frame dampers sized to fit the inside of ducts at wall penetrations with minimum air flow interference.

b. Dampers shall be fusible-link operated ( $160 \mathrm{~F}$ fusion point), gravity closing, self locking against a minimum of 2,000 feet per minute air velocity in the duct.

c. Dampers shall be of the multi-blade type with the blades being horizontal.

a. Blades: 16 gauge galvanized steel.

e. Blade length: 48 inches maximum.

f. Blade width: 4 inches minimum, 6 inches maximum.

g. Blade shafts: $\frac{1}{2}$ inch diameter, rustproofed.

h. Bearings: oil impregnated bronze sleeves.

i. Frames: $2 \times 1 / 2 \times 1 / 8$ inch welded and braced frames galvanized after fabrication.

j. Dampers shall be equipped with bar stops, weights, spring catch, ard $160 \mathrm{~F}$ fusible link.

k. Dampers sha.l be American Warming and Ventilating Co. Type 801 modified as specified above, or approved equal.

33. FIRE DAMPERS EPN 324-8900-985 (QUANTITY AS SHOWN ON THE DRAWINGS)

a. Dampers shall be as specified in section 32 except frame shall be mounted horizontally inside of ducts at floor penetrations.

34. COUNPER-BAIANCED SHUTTER EPIL 324-8900-958 (4 REQUIRED)

a. Shutter shall be of the size indicated on the drawings and shall be of the multi-blade type with the frame being mounted vertically and ine blades being horizontal.

b. Blades: 16 gauge galvanized steel minimum.

c. Blade length: 48 inches maximum. 
34. COUNTER-BALANCED SHUTTER EPN-324-8900-958 (4 RERUIRED) (Cont.)

d. Blade width: 4 inches minimum, 10 inches maximum.

e. Blade shafts: $\frac{1}{2}$ inch diameter

f. Bearings: oil impregnated bronze sleeves.

g. Frames: $1-1 / 2^{\prime \prime} \times 4^{\prime \prime} \times 14$ gauge anglé (minimum), manufacturer's standard finish.

h. Shutter shall be designed for a pressure differential of 5 inches, w.g。

i. Counter-balance shall be adjustable.

j. Normal air flow direction is toward the wall surface to which the damper flange is attached.

k. Shutter shall be American Foundry and Furnace Company, Counter Balanced Shutter CB-12, modified as specified above, or approved equal.

35. COUNIEER-BAIANCED SHUTTER EPN 324-8900-982 (2 REQUIRED)

Shutter shall be as specified in Section 34 except as follows:

a. Frame will be mounted horizontally on the bottom inside of a duct with the blades being perpendicular to the length.

b. Shutter shall be designed for a duct pressure of 2 inches vater gauge and shall open when the duct pressure is a negative $1 / 8$ inch water gauge or numerically less.

36. COUNTER-BATANCED SHUTTER EPN 324-8900-981

a. Shutters shall be of the quantity and size as shown on the drawings. Shutters shall be of the multi-blade type suitable for mounting in either the vertical or horizontal plane.

b. Shutter shall be designed for a pressure differential of 3 inches, w.g.

c. Blades: aluminum of adequate strength for the design pressure. Blades shall either encase the blade shafts or be mounted on the downstream side of the shafts. Blades shall be approximately 4 inches wide and shall be linked together. 
36. COUNTER-BATANCED SHUTTERR EPN-324-8900-981 (Cont.)

d. Blade shafts: carbon steel of adequate size for the design pressure. One shaft shall extend through the frame for attachment of the counter-balance.

e. Bearings: oil impregnated bronze sleeves except extension shafts for connection to counter-balance which shall be ball bearings.

f. Frames: flanged channel construction of aluminum for installation between mating flanges, 12 gauge minimum.

g. Counter-balance: externally mounted and adjustable on the counterbalance arm. Counter-balance arm position on the control shaft shall be adjustable.

37. COUNTHR-BAIANTCED BACK FLOW DAMPERS EPN 324-8900-983

a. Dampers shall be of the quantity and size as shown on the drarings.

b. Dampers shall be of the multi-blade type suitable for vertical frame mounting.

c. Blades: 16 gauge galvanized steel minimum.

d. Blade length: 48 inches maximum.

e. Blade width: 4 inches minimum, 10 inches maximum.

f. Blade shafts: $\frac{1}{2}$ inch diameter.

g. Bearings: oil impregnated bronze sleeves.

h. Frames: $2^{\prime \prime} \times 1 / 2^{\prime \prime} \times 1 / 8^{\prime \prime}$ channel, manufacturer's standard finish.

i. Counter balance shall be adjustable.

-j. Damper shall be American Foundry and Furnace Company Counter Balanced Shutter CB-12, or approved equal.

38. COUNTER-BALANCED BACK FLOW DAMPERS EPN 324-8900-984

Back Ilow damper shall be as specified in Section 37 except that it shall be designed for horizontal frame mounting.

39. SQUARE AIR DIFFUSERS EFN 324-8900-930

a. Square diffusers shall be four-way blow of the adjustable patterm type for ceiling installation. Quantity and size shall be as shown on the drawings. 
39. SQUARE AIR DIFFUSERS EPIN 324-8900-930

b. Diffuser and accessories shall be aluminum contruction.

c. Blanking plates shall be provided as shown on the drawings.

d. Diffusers shall be Carnes Corporation Type KSA, equipped with Model 5S opposed blade damper and Hodel EDS equalizing deflector modified as specified above, or approved equal.

40. SQUARE AIR DIFFUSERS EPN 324-8900-932

Diffusers shall be as specified in Section 39 except that material of construction shall be carbon steel with manufacturer's standard finish.

41. RECTANGULAR SUPPLY REGISTTERS EPN 324-8900-93I

a. Rectangular ceiling supply registers shall be of the three-way directiona type with louvers on left and right sides parallel to the short dimension. Louvers shall be extruded aluminum of curved design. Quantity and size shall be as shown on the drarings.

b. Register and accessories shall be aluminum construction.

c. Register shall be equipped with opposed blacde damper operated from a key operator at the face of the outlet.

d. Register shall be Titus Mfg. Corp. No. 2035, modified as specified above, or approved equal.

42. RECTANGULAR SUPPLY REGISTERS EPII 324-8900-929

a. Rectangular supply registers shall be of the double deflection type with horizontal front bars and vertical rearr bars individually adjustasie to any deflection setting. Quantity and size shall be as shown on the drawings.

b. Register and accessories shall be of alumimum constmaction.

c. Register shall be equipped with opposed blaxde damper (vertical blades) operated from a key operator at the face of the outlet.

d. Register shall be Titus MIG. Corp. Model CLis-277, or approved equal. 
43. RECTAIVGULAR SUPPLY REGISTERS EPIN 324-8900-934.

Registers shall be as specified in Section 42 except that material of construction shall be carbon steel with manufacturer's standard finish and shall be Tuttle \& Bailey T557, or approved equal.

44. CIRCUILAR AIR DIFFUSERS EPN 324-8900-935

a. Circular diffusers shall be of the adjustable pattern type for ceiling or exposed duct installation. Quantity and size shall be as show on the drawings.

b. Diffusers shall be Anemostat Corporation Type C-2 with equalizing grid and volume control "Combo Unit No. 2", or approved equal.

45. RECTANGULAR AID DIFFUSERS EPIN 324-8900-936

a. Rectangular diffusers shall be two-way blow type with removable core. Quantity and size shall be as shown on the drawings.

b. Diffusers shall be equipped with opposed blade damper units.

c. Diffusers shall be Titus Manufacturing Corporation Model THDC, Frame Style SI, Pattern 2A, or approved equal.

46. RECTANGULAR AIR DIFFUSERS EPN 324-8900-937

a. Rectangular diffusers shall be three-way blow type with removable core. Flow quantities shall be rated at $50 \%$ front and $25 \%$ each side. Quantity and size shall be as shown on the drawings.

b. Diffusers shall be Titus Manufacturing Corporation Model TiDC, Frame Style SI, Pattern 3B, or approved equal.

c. Diffusers shall be equipped with opposed blade damper units.

47. RECTANGULAR AIR DIFFUSERS EPN 324-8900-938

a. Rectangular diffusers shall be three-way blow type with removable core. Flow quantities shall be rated at $60 \%$ front and $20 \%$ each side. Quantity and size shall be as shown on the drawings.

b. Diffusers shall be equipped with opposed blade damper units.

c. Dirfusers shall be Titus Manufacturing Corporation Model TMDC, Frame Style SI, Pattern 3E, or approved equal. 
48. RECTANGULAR MODULAR $\Lambda$ IR DIFFUSERS EPN 324-8900-939

a. Rectangular modular air diffusers shall be four-way blow type with removable modules having one-way and corner blow patterns. Quantity and size shall be as show on the drawings.

b. Modules shall be approximately six inches squaxe and may be either metal or plastic in construction.

c. Diffusers shall be equipped with opposed blade damper units and equalizing deflectors.

d. Diffusers shall be Carnes Corporation Model "M", Size No. $22 \mathrm{P}$ with Model 7S opposed blade damper and Model EDS equalizing deflector, or approved equal.

49. RECTANGULAR MODULAR AIR DIFHUSERS EPN 324-8900-940

Diffusers shall be the same as that specified in Section 48 except size shall be No. 23P.

50. RECTANGULAR MODULAR AIR DIFFUSERS EPI 324-8900-941

Diffusers shall be the same as that specified in Section 48 except size shall be No. $24 \mathrm{P}$.

51. RECTANGULAR MODULAR AIR DIFFUSERS EPN 324-8900-942

Diffusers shall be the same as that specified in Section 48 except size shall be No. 26P.

52. EXHAUST REGISTERS EPIN 324-8900-933

a. Exhaust register shall consist of a plain lattice design face attached to a key operated opposed blade damper unit. Quantity and size shell te as shown on the drawings.

b. The grille shall be fabricated of No. 12 gauge stamped stainless steel with 0.800 inch square openings and 0.182 inch bars. The margin shelI be $1-1 / 4$ inches.

c. All material shall be stainless steel.

d. Registers shall be Tuttle and Beiley No. 7908 modified as specified eicore: or approved equal. 
53. EXHAUST REATSTERS EIFN 324-8900-949

Registers shall be as specified in Section 52 except that materzal of construction srall be alurinurio

54. EXHAUSI REGISTEPS EPN 324-8900-950

a. Registers shall be as specified in Section 52 except that material of construction shall be carbon steed rith manufacturex ${ }^{\prime}$ s standard firisi.

55. RETURTI REGISTERS EPJI 324-8900-951

a. Return registex shall consist of curved, hemmed edge, blades attached to a $k s y \infty$ op $=$ rated, opposed blade, damper unit. Quantity and size sna be as ahown on the drawings.

b. Return reglsters shall be Carnes Corporation Model 600-H, or approved equal.

56. IATTICE GRIILE EPN 3214-8900-952

a. Plain lattice grille shall be No. 12 gauge stamped steel with 0.800 inc: square openings and 0.182 inch baxs. The margin shall be $1-1 / 4$ inches.

b. Grille shall be Tuttie and Bailey No. 575E, or approved equal.

57. GRAVITY ROOF VENIILATOR EEN 324-8900-960 (I RERTIRED)

a. The ventilator shall be a pressure relisf ventilator equipped with councer-balanced back flow damper.

b. Ventilatcr shall be of gluminum construction.

c. Housing outlpts shall be equipped vith a removable bird screen with stiffened edges. Screen shall be No. 2 galvanized wire mesh with. I/2 inch openings.

d. The ventilator shajl be complete with a base section suitable for mounting on a roof curb approximately 4 inches wide and approximately 8 inches above the finished roof. Rosf opening and curb details are shown on Draving H-3-20170. Ventilator location is shorm on Drawing $\mathrm{H} \approx 3-20169$.

e. Ventilator shall be Carnes Corporation Model RV-12, or approved equel.

58. GRAVITY ROOF VENTILATOR EPN 324-8900-961 (2 REQUTRED)

Ventilator shall be as specified in section 57 except that it shall be Carnes Corporation Model RV-28, or approved equal. 
59. GRAVITY ROOF VENITILATOR EPN 324-8900-962 (2 REQUIRED)

Ventilator shall be as specified in Section 57 except that it shall be Carnes Corporation Model RV-28, or approved equal.

60. GRAVITY ROOF VENTII.ATOR EPN 324-8900-963 (4 REQUIRED)

Ventilator shall be as specified in Section 57 except that it shall be Carnes Corporation Model RV-32, or approved equal.

61. POWER ROOF VEITIILATOR EPN 324-8900-978 (I REQUIRED)

a. Power roof ventilator shall be of the centrifugal wheel type with counterbalanced back flow damper complete and ready for use.

b. Ventilator shall have the certified rating of AMCA attached.

c. Wheel shall have backwardly inclined blades with non-overloading power characteristics.

d. Wheel shall be dynamically balanced in accordance with manufacturer's standard practice.

e. Fan shall have a capacity of $4,600 \mathrm{cfm}$ at $3 / 8$ inch of water gauge static pressure.

f. Fan wheel shall be at least 33 inches in diameter and speed shall not exceed $420 \mathrm{rpm}$.

g. Motor shall conform to the standards of NEMA and AIEE for ratings, performance characteristics, insulation values and mounting dimensions, and shall have a service factor of $115 \%$. Rating shall be for continuous operation, normal torque and staxting current. Motor shall not be overloaded when ventilator is operated at rated speed. Ambient temperature is $85 \mathrm{~F}$.

h. Motor shall have ball bearings and shall be enclosed in open dripproof enclosures. Motor shall operate on three phase, 440 volt, 60 cycle power supply.

i. Motor base shall be equipped with steel slide rail or equivalent for adjustment of belt tension.

j. Fan shall be V-belt driven and belts shall be designed for 150 percent of driving motor horsepower rating. Sheaves for drives shall be adjustable to plus or minus 10 percent of specified rating and shall have been balanced per manufacturer's normal balancing requirements. 
61. POWER ROOF VENTILATOR EPN 324-8900-978 (1 REQUIRED) (Cont.)

k. Vibration isolators shall be provided to isolate the wheel and drive assembly from the base section.

1. Motor and drive unit shall be enclosed in a weatherproof steel or aluminum housing. Housing shall be easily removable or equipped with removable panels for access to motor, fan, and drive units.

m. Motor and drive unit compartment shall be adequately ventilated to dissipate motor heat.

n. Housing outlets shall be equipped with a removable bird screen with stiffened edges. Screen shall ve No. 2 galvanized wire mash with $1 / 2$ inch openings.

o. The ventilator shall be complete with a base section suitable for mounting on a roof curb approximately 4 inches wide and approximately 8 inches above the finished roof. Roof opening and curb details are shown on Drawing H-3-20170. Ventilator location is shown on Drawing $\mathrm{H}-3-20169$.

p. Ventilator shall be Carnes Corporation Model BE-33, or approved equal.

62. POWER ROOF VENTILATOR EPN 324-8900-979 (I REQUIRED)

Power roof ventilator shall be as specified in Section 61 except as follows:

a. Fan shall have a capacity of $5545 \mathrm{cfm}$ at $3 / 8$ inch spwg。

b. Fan wheel shall be at least 33 inches in diameter and speed shall not exceed $420 \mathrm{rpm}$.

c. Ventilator shall be Carnes Corporation Model BE-33, or approved equal.

63. POWER WALI VENTIIATOR EPN 324-8900-980 (1 REQUIRED)

a. Power wall ventilator shall be of the centrifugal wheel type with counterbalanced back flow damper and wall grille complete and ready for use.

b. Wheel shall have backwardly inclined blades with non-overloading power characteristics.

c. Wheel shall be dymamically balanced in accordance with manufacturer's standard practice. 
63.. POWER WALL VENTILATOR EPN 324-8900-980 (1 REQUIRED) (Continued)

d. Fan shall have a capacity of 400 cfm at 0.05 inch spwg.

e. Fan wheel shall be at least 9 inches in diameter and speed shall not exceed $1100 \mathrm{rpm}$.

f. Motor shall conform to the standards of NEMA and AIEE for ratings, performance characteristics, insulation values and mounting dimensions, and shall have a service factor of $115 \%$. Rating shall. be for continuous operation, normal torque and starting current. Motor shall not be overloaded when ventilator is operated at rated speed.

g. Motor shall have ball bearings and shall be enclosed in open drip. proof enclosure. Motor shall operate on single phase, 120 volt, 60 cycle, power supply.

h. Vibration isolators shall be provided to isolate the wheel and drive assembly from the base section.

i. Motor and drive unit shall be enclosed in a weatherproof steel or aluminum housing. Housing shall be easily removable for inspection and maintenance of the motor. Housing shall be adequately ventilatej to dissipate motor heat.

j. Housing outlets shall be equipped with removable bird screen with stiffened edges. Screen shall be No. 2 galvanized wire mesh with $\frac{1}{2}$ inch openings.

k. Ventilator shall be Carnes Corporation WD-9A with Model W-3 grille, or approved equal.

64. MEDIUM EFFICIENCY FIITERS EPN 324-8900-965 (21 REQUIRED)

a. Filters shall have a minimum efficiency of $50 \%$, i.e.g the penetraticr of 0.3 micron diameter, homogeneous particicles of dioctyl phthelate (DOP) particles shall not exceed $50 \%$ when tested in accordance with Military Standard MIL SID-282, dated May 28, 1956, methods 102.1 ard 102.9 .

b. Filters shall withstand normal, continuwous operating conditions of 70 to $120 \mathrm{~F}$ air with relative humidity from 40 to $90 \%$ without loss of filtering efficiency.

c. Filter medium shall have no holes, cracles, slits or other visual imperfections. The medium shall not be patched. Medium shall be 
64. MEDIUM EFFICIENCY FILTERS EPN 324-8900-965 (2I REQUIRED)

c. (Continued)

overlapped at least $11 / 2$ inches at splices and there shall be no more than one splice per filter. Splices shall not be located at folds. Filter medium shall be made of glass fibers.

d. Filter shall have a minimum capacity of $1500 \mathrm{cfm}$ of air at a maximu pressure arop of 0.35 inches water gauge.

e. Filter cartridge shall be approximately $23 \frac{1}{2}$ inches $\times 23 \frac{1}{2}$ inches $x$ $11 \frac{1}{2}$ inches thick.

f. Each filter cartridge shall be equipped with a cadmiun plated steel retainer frame complete with cartridge fasteners.

g. Suitable gaskets shall be provided either on the cartridge or on the retainer frame so as to prevent the leakage of air between the finte: cartriage and the retainer frame.

h. The manufacturer shall make the following tests on each completed filter to verify conformance to performance requirements:

(1) Efficiency (penetration) test as noted above.

(2) Air llow resistance test at rated flow with air at conditions indicated above.

i. Each filter will be subjected to the following tests by the Commission:

(1) DOP penetration test.

(2) Resistance at rated air flow as specified above.

(3) Visual check of filter.

j. Each filter shall be indelibly and legibly marked with the followirz information:

(1) The results of the manufacturer's penetration and air pressure tests including the test air flow rate.

(2) Manufacturer's name, model number, serial number and date of test.

(3) DOP test air flow direction with an arrow and the word "IESI" in letters 1 inch high.

$k$. The shipping container shall be prominently marked with "IHIS SIDE i:" signs and arrows to show filter placement in the container. 
64. MEDIUM EFFICIENCY FIITERS EPN 324-8900-965 (21 REQUIRED) (Continued)

1. Filters shall be Mine Safety Appliances Company Dustfoe Space Filter, or approved equal.

65. HIGH EFFICIENCI FIITERS EPN 324-8900-966 (200 REQUIRED-196 INSTAIIED)

Filters shall be as specified in Hanford Standard Specification

HWS-75II-S, "High Efficiency Particulate Air Filters"。 In addition, the following shall apply:

a. Filters shall be of the moisture resistive type having nonmetallic separators.

b. Outside frame dimensions: exclusive of gasket, shall be 24 inches $x 24$ inches $x 11 \frac{1}{2}$ inches deep.

c. Flow rate shall be 1000 scfm at an initial resistance of 1 inch water gauge.

d. Filters will be tested in accordance with Section 8.2 a. of Hanforl Standard Specification HWS-75II-S by the Commission, with 4 filters tested in accordance with sections 8.2a. and $8.2 \mathrm{~b}$.

66. HIGH EFFICIENCY FILTER CARTRIDGE ASSEMBLY EPN 324-8900-967-A (3 REQIIRE:

a. Filter cartridge assembly shall be complete as shown on Drawing H-3-20425 and shall be as specified in Hanford Standard Specificstion HWS-7511-S, "High Efficiency Particulate Air Filters" with the exception of Sections 4 and 6.5 which do not apply. In addition, the following shall apply:

(1) Filters shall be of the moisture resistive type having normetallic separators.

(2) Flow rate shall be $1000 \mathrm{scfm}$ at an initial resistance of 1 inch water gauge.

(3) Filters will be tested in accordance with Section 8.2a. of Hanford Standard Specification HWS 751 l-S by the Commission.

67. HIGH EFFICIENCY FILTER CARTRIDGE ASSEMBIX EPN 324-8900-967-B (I REQUIPD)

Filter cartridge assembly shall be complete as shown on Drawing $\mathrm{H}-3-20 \mathrm{~L} 23$ and be as specified in Section 66 above.

68. LOW EFFICIENCY FIITERS EPN 324-8900-968 (20 REQUIRED)

a. Filter shall consist of fibrous glass media encased in a fibre frame with suitable retainers on the upstream and downstream faces of tre filter. 
68. LOW EFFICIENCY FILTERS EPN 324-8900-968 (20 REQUIRED) (Continued)

b. Filter shall be 24 inches $x 24$ inches $x I$ inch thick.

c. Filter shall have a rated minimum flow of 1500 cfm at a maximum resistance of 0.15 inches water gauge.

d. Filter shall be Owens-Corning Fiberglass Corporation Comercial Dust stop Filter modified as specified above, or approved equal.

69. VENTIIATION GRAPHIC PANEL EPN 324-5902-425 (I REQUIRED)

The heating and ventilation control panel shall be as shown on arawing H-3-20364. Part numbers of the items specified in this section also refer to parts list on drawing $\mathrm{H}-3-20364$.

69.1 PRESSURE CONTROLIER - MINIATIRE, EPN 324-5902-425-I (4 REQUIRED)

The pressure controller, Part No. 2, shall conform to the following requirements:

Input - Pneumatic, 3 to 15 psig

Output - 15 to 3 psig, proportional

Chart - Nominal $4^{\prime \prime}$ strip, speed $1^{\prime \prime}$ per hour, graduated 0 to 100 percent uniform.

Scale - Graduated 0 to 100 percent uniform

Control Modes - Adjustable 0 to 100 percent, proportional band.

Reset - 0.1 to 50 minutes

Accessories - Adjustable isolated SPDT switch, rated 1 Amp, 120 F. AC, for actuating remote alarm. Contacts to close on either upscale or downscale pen travel.

Power - $120 \mathrm{~V}, 60$ cycle AC.

Marik \& EPN 324-425-1

69.2 DIFFERENTIAI PRESSURE INDICATOR, EPN 324-5902-425-2 (6 REQUIRED)

The differential pressure indicators shall conform to the following requirements :

Range - 3 to 15 psig

Scale - 0 to 5 inches of water

Size - Nominal 3 inches

Connections - Back, 1/4" female NPT

Mounting a Flush

Mark - EPN 324-425-2 
69.3 ANRTNCIATOR - I8 POINT EPN 324-5902-425-3 (1 REQUTRED)

The annunciator shall conform to the following requirements:

Type - Flush mount, backlighted nameplates.

Power - $120 \mathrm{~V}, 60$ Cycle AC.

Sequence - Normal - Dim lighted nameplate

Off Normal - Flashing bright

Acknowledged - Steady bright

Reset - Dim lighted nameplate

Normal - Dim lighted nameplate

Field Contacts - Close to alarm

Accessories wach position to contain SPST auxiliary contact to close at all sequence position except "Norrual"

Audible - Complete with 120 volt, 60 cycle, AC alarm hom.

Nameplate Size $2^{\prime \prime} \times 3^{\prime \prime}$

Mark - EPN 324-425-3

70. VENTILAPION EXHAISST TRANSMTTIER RACK, PART NO。 1 \& NO. 2

The transmitter racks shall be constructed and equipped as show on Drawing $\mathrm{H}-3-20384$ and specified herein.

70.1 TRANSMITTER, PART NO. 11 (3 REQJIRED)

The transmitter shall conform to the following requi rements:

Differential Range - 0 to 20 inches water column

Output - 3 to 15 psig pneumatic

Calibrated Range - 0 to 10 inches water coluran

Adjustmert - 20 to 100 percent of full range

Type - Dry bellows

Materiais o Manufacturer's Standard

Static Pressure Rating - 10 iriches water, vacuum

Input Air - 20 psig

Mounting - Wall surface mounting

Connections - Differential taps: $1 / 4^{\prime \prime} \mathrm{NPT}$ female

Air Connections w $1 / 4$ " NPT female

Accessories - To be equipped with $21 / 2^{\text {rt }}$ nominal receiver gauge on output, calibrated 3 to 15 psig

Mark - Bldg. 324-PT.II - H-3-20384

70.2 TRANSMITTER, PARI NO. 25 (6 REQUIRED)

Transmitter shall conform to the following requirements:

Differential Range - 0 to 20 inches watex column 
70.2 TRANSMITTER, PART NO. 25 (6 REQUIRED) (Continued)

Output is 3 to 15 psig pneumatic

Calibrated Range - 0 to 5 inches water column Aajustment o 20 to 100 percent of full range Type - Dry bellows Materisis - Manufacturex's standard

Static Pressure Rating - 10 inches water vacuum Irput Air - 20 psig

Mounting - Surface wall mounting

Connections - Differential Taps 1/4" NPT female

Air Connections = $1 / 4$ " NPT female

Accessories - To be equipped with $21 / 2$ " nominal receiver gauge on output, calibrated 30 to 15 psig.

Mark - Bldg. $324=$ Pt. $25-\mathrm{F}=3-20384$

71. ZONE REHEATER STEAM SUPPLY VAITES

The steam control valves specified below will operate with the coils specified in Section 23, and are shown on drawings $\mathrm{H}-3-20363$ and $\mathrm{H}-3-20485$.

71.1 DIAPHRAGM OPERATED VALTES (DOV)

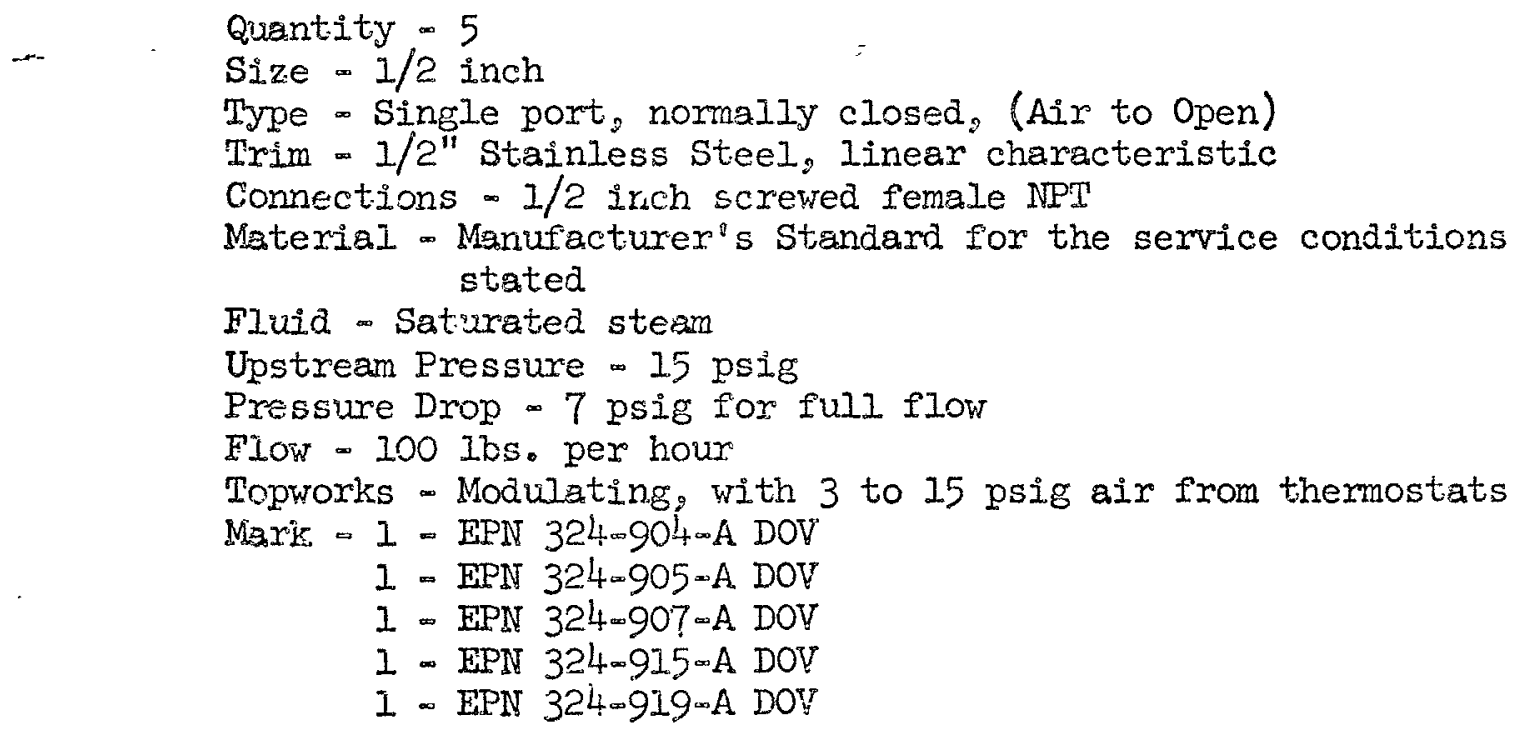

\subsection{DIAPHRAGM OPERATED VALVE}

Quantity: 1

Size - $1 / 2$ inch 
7..2 DIAPHRAGM OPERATED VALVE (Continued)

Type - Single port, normally closed, (Air-to-open)

Trim - 3/8 inch Stainless Steel, linear characteristic

Connections - $1 / 2$ inch screwed female NPT

Material - Manufacturer's standard for the service conditions stated. Fluid - Saturated steam

Upstream Pressure - 15 psig

Pressure Drop - 7 psig for full flow

Flow - 45 Ibs. per hour

Topworks - Modulating with 3 to 15 psig air from thermostat.

Mark - EPN 324-908-A - DOV

\section{T2.3 DIAFHRAGM OPERATEDD VALVES}

Quantity $=3$

Size - 3/4 inch

Type - Single port, normally closed, (Air-to-Open)

Trim - 3/4 inch Stainless Steel, Iinear characteristic

Connections - $3 / 4$ inch screwed female NPT

Material - Manufacturer's standard for the service conditions stated Fluid - Saturated steam

Upstream Pressure - 15 psig

Pressure Drop - 7 psi for full flow

Flow - $150 \mathrm{lbs}$ per hour

Topworks - Modulating with 3 to 15 psig air from thermostat

Mark - 1 - EPI 324 - 906-A - DOV

1 - EPN 324-913-A - DOV

1 - EPN 324-917-A - DOV

\subsection{DIAPHRAGM OPERATED VALVES}

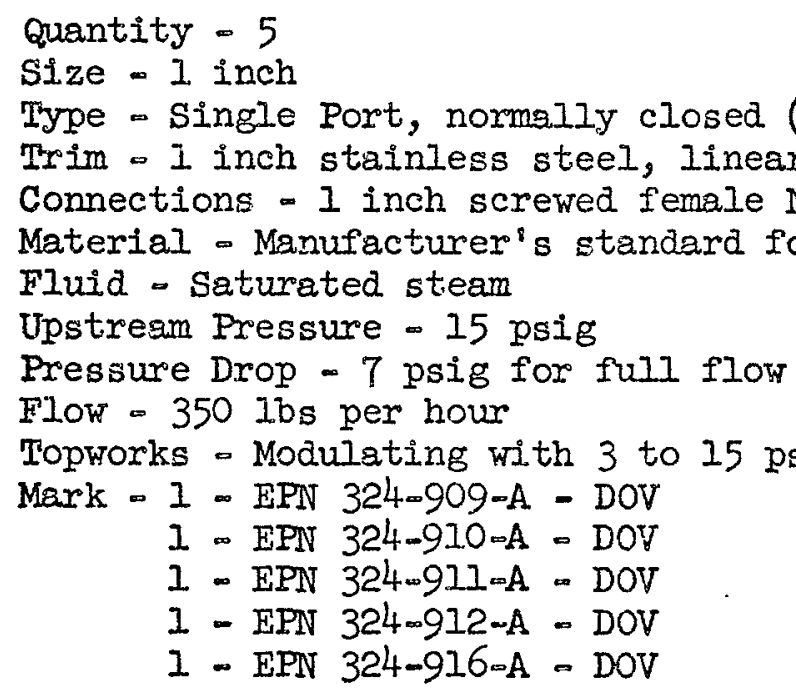




\subsection{DIAPRRAGM OFERATED VALVES}

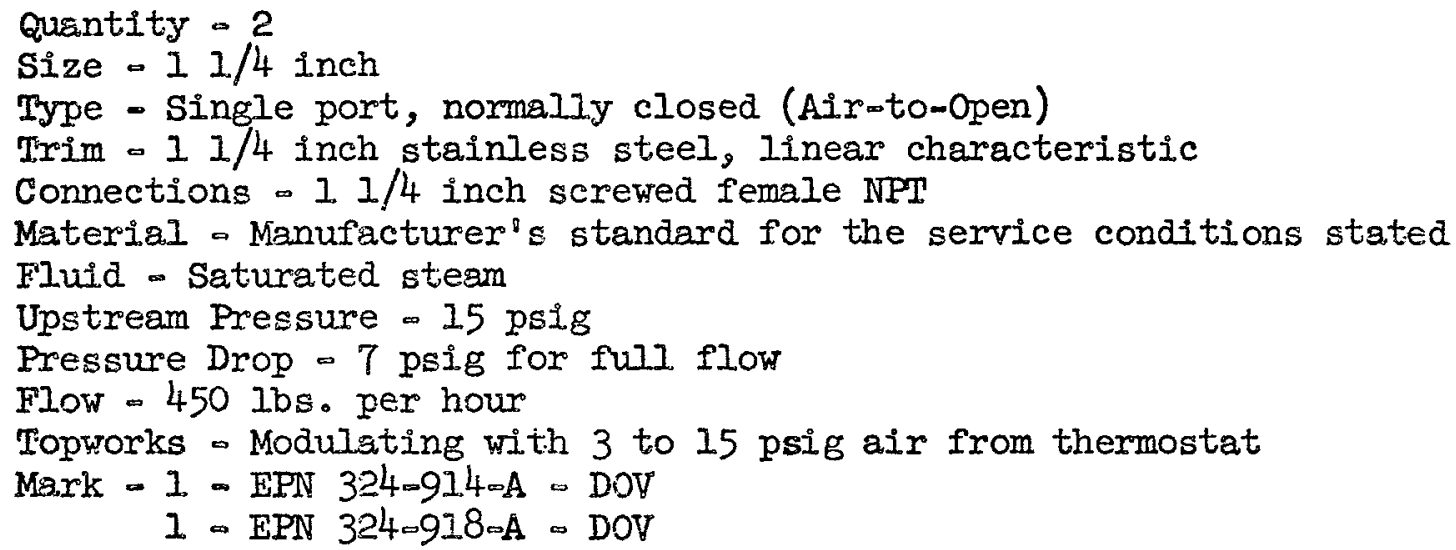

72. SUPPLY FAN UNIT STEAM COII VALVES

The steam regulating valves specified below will operate with the heating coils specified in section 23 and are shown on drawings $\mathrm{H}-3-20363$ and $\mathrm{H}-3-20384$ 。

\section{T2.I DIAPHRAGM OPERATED VALVES}

Quantity $\infty 2$

Size - $21 / 2$ inch

Type o Single port, normally closed, (Airwto-Open)

Trim - 2 I/2 inch stainless steel, linear characteristic

Connections - 2 l/2 inch, 150\# flanged, AsA

Material - Manufacturers Standard for service condition stated

Fluid - Saturated steam

Upstream Pressure - 15 psig

Pressure Drop - 7 psi at full flow

Flow - 1800 Ibs. per hour full open

Topworks w Modulating with 3 to 15 psig air from temperature controller

Mark - I EPN 324-901-BV - DOV

1 EPN $324 \infty 902-B V=$ DOV

72.2 THMPERATURE REGULATING VALVES

Quantity - 2

Size - 2 inch

Type - Vapor filled temperature bulb, normally closed, (opens=on failing temperature)

Trim -2 inch stainless steel.

Connections - 2 inch, 150\# flanged, ASA

Material w Manufacturer's standard for service conditions stated 
Fluid - Saturated steam

Upstream Pressure - 125 psig

Pressure Drop - 35 psi at full flow

Flow - 7250 lbs. per hour full open

Operator - Vapor bulb and capillary length $15 \mathrm{ft}$. for duct mounting

Throttling Range - Valve to start opening at $45 \mathrm{~F}$ and be full open at $40 \mathrm{~F}$

Mark - I EPN 324-90I $-\mathrm{FV}$ - IRV

1 EPN 324-902 -FV - TRV

\section{T2.3 TEMPERATURE REGUTATING VALVES}

Quantity $=1$

Size $=1 / 2$ inch

Type - Vapor filled temperature bulb, normally closed, (Opens on falling temperature)

Trim $-1 / 2$ inch, stainless steel

Connections - $1 / 2$ inch screwed female NPT

Material - Manufacturer ${ }^{\circ} \mathrm{s}$ standard for service conditions stated

Fluid - Saturated steam

Upstream Fressure - 125 psig

Pressure Drop - 40 psi for full flow

Flow - 325 Ibs. per hour for full open

Operatior a Vapor bulb and capillary length $15 \mathrm{ft.}$, for outside mountins

Throttling Range - Valve to start opening at $45 \mathrm{~F}$ and be full open at $40 \mathrm{~F}$.

Mark - EPN 324-903-CV - TRV

73. SUPPLY FAN INSTRUMENP AND CONTROLS

The instruments specified below are shown on drawings $\mathrm{H}-3-20363$ and $\mathrm{H}-3-20305$.

73.1 DIFFERENTIAL PRESSURE INDICATORS

Quantity - 5

Size - Nominal 3 inch diameter

Range s 0 to $I$ inch of water, differential

Scale - Graduated in tenths and hundredths of inches of water

Mounting - Semi-flush

Connections $1 / 8$ inch screwed female NPT

Representative Type - Magnehelic gage as manufactured by $F$. W. Dwyer $\mathrm{Mfg}$. Co., or approved equal.

Mark - $1-\mathrm{BIdg} .324=1$ DPI 2

$1-$ BIdg. $324-2$ DPI 2 


\subsection{DIFFERENTIAL PRESSURE INDICATORS (Continued)}

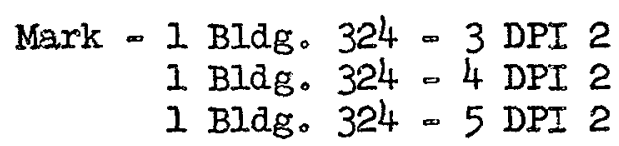

73.2 DIFFERENIIA工 PRESSURE INDICATOR

Quantity $=1$

Size - Nominal 4 inch diameter

Range - 0 to 2 inches water differential

Scale - Graduated in .05 inches water

Mounting - Semi $-f l u s h$

Connections - 1/8 inch screwed female pipe

Representative Type o Magnehelic gage as manufactured by $F$ 。 $W$

Mark - BIdg. $324-6$ DIP 2 Dwyer $\mathrm{Mfg}$. Co., or approved equal.

\subsection{TEMPERATURE CONTROLIER}

Quantity - 3

Range - 40 to $70 F$ nominal

Type - Blind, nonoindicating, pneumatic

Input - Averaging bulb installed downstream of air washer. (In the case of supply fan 903, downstream of filter)

Output - 3 to $15 \mathrm{psig}$ aix to inlet face-and-bypass damper

Throttling Range a Adjustable between 0 and $10 \mathrm{~F}$, reversible

Set Point Adjust - Indicating, by screwdriver slot or key adjustment.

Mounting - Surface mount

Element Length o Sufficient length to traverse the airstream a minimum of 4 times for average temperature.

Element Materials - Copper or brass

Element Mounting - To include protective splash shield to prevent the element from becoming wetted from the washer.

Mark - I - BIdg。 324 - ITC 2

1 - BIdg. $324-3$ IC 2

1. BIdg. $324-5$ IC 2

73.4 TEMPERAMURE CONTKOTT.ERS

Quantity - 2

Range - 50 to $90 \mathrm{~F}$

Type - Blind non-indicating, pneumatic

Input - $12^{\prime \prime}$ long bulb, mounted thru duct wall of fan discharge duct.

Output - 3 to 15 psig air to a normally closed reheat diaphragm operated steam valve DOVa9OI BV. 
73.4 TEMPERATURE CONTROLLERS (continued)

Throttling Range - Adjustable between 0 and $10^{\circ} \mathrm{F}$, reversible

Set Point Adjust - Indicating, by screwariver slot or key adjustment.

Mounting - Surface mount

Element Material - Copper or brass

Mark - I - Bldg. $324-2 \mathrm{TC} 2$

$1-B 1 d g \cdot 324-4 m 2$

73.5 TEMPERATURE INDICATORS

Quantity - 5

Range - (-) 40 to $110^{\circ} \mathrm{F}$

Size - Nominal 6 inch diameter

Scale - Graduated 2 degree divisions

Mounting - Duct mounting without well

Stem Length - 6 inches

Type - Biw Metallic sensing tip

Mark - 1 - Bldg. 324 - I TI 2

1 - Bldg. $324-2$ TI 2

I- BIdg. $324-3$ TI 2

$1-B I d g \cdot 324-4$ TI 2

I. BIdg. $324-5$ TI 2

74. TEMPERATURE CONTROL SYSTEM - ADMINISTRATION AREA

Quantity - 1

Type - Electronic - Pneumatic Relay 
74. TEMFERATTRE CONTROI SYSTEM - ADMINISTRATION AREA (contimuea)

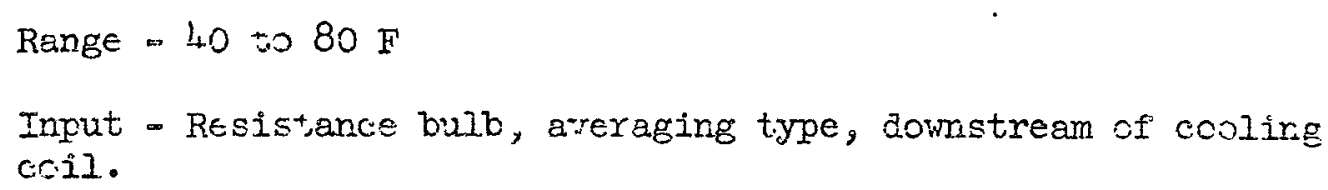

Throttling Range - Adjustable from 1 to $30 \mathrm{~F}$ for 3 to $13 \mathrm{psi}$ branch line pressure charge.

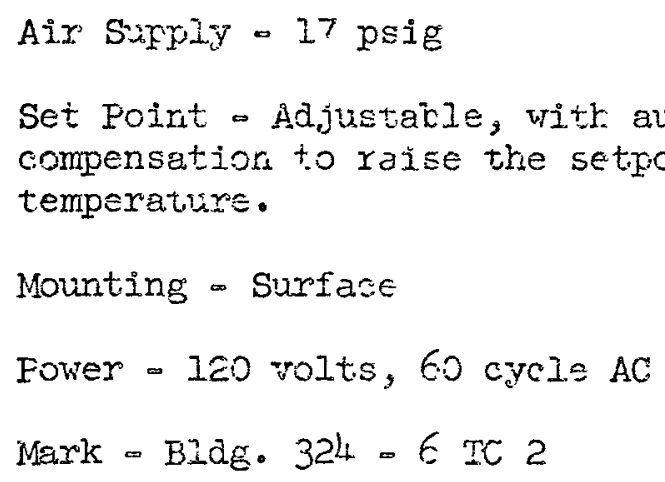

75. THERMOSTASS

The thermostats epecified below are shown on drawirgs H- 320363 ari $\mathrm{H}-3-20296$ through $\mathrm{H}-3=20305$.

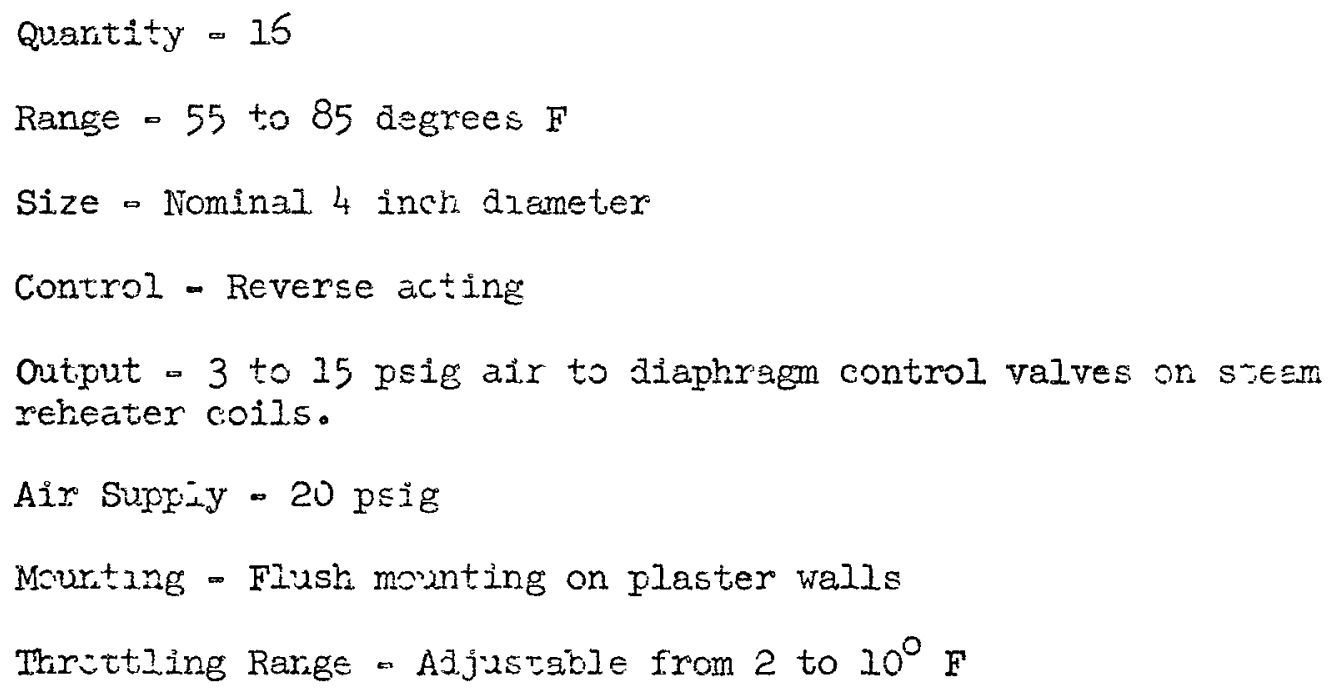


75. THERMOSTATS (cortinued)

Set Point - Adjustable from 55 to $85^{\circ} \mathrm{F}$ by external knob

Indicator - Dial type thermometer to indicate temperature

Mark - See Drawing Plans for Identification

BIdg. $324-1$ TS 2 through 16 TS 2

76. STATIC PRESSURE CONTROL

The static pressure control instruments specified below are show on drawings $\mathrm{H}-3-20385, \mathrm{H}-3-20305$, etc.

76.1 DIFFERENTTAL PRESSURE TRANSMITTERS

Quantity - 12

Range $=0$ to 0.5 inches of water column

Element - Flexible diaphragm, dry meter

output - 3 to 15 psig air

Sensitivity - Adjustable to give 2 psi output change with 0.01 inches water gauge input changes. The transmitter shall be restricted feed, constant waste type.

Action - Direct acting, increasing output with increasing differential.

Air Supply o 20 psig air

Differential Connections o I/4 inch female NPT

Air Connections - $1 / 4$ inch female NPT

Body Materials - Manufacturer's standard

Mounting - Universal wall or pipe stand mount

Representative Type - Republic Flow Meter Co. Model Pe0307, or approved equal. 
76.1 DIFFERENTIAI PRESSURE TRANSMITTERS (continued)

$$
\begin{aligned}
& \text { Mark - I . Bldg. 324 } \approx \text { DPT } \propto 957 \approx M \\
& \text { 1 - Bldg. } 324 \text { - DPT-957-P } \\
& \text { I - Bldg. } 324 \text { - DPT-957-IB } \\
& 1 \text { - Bldg. 324 - DPT-956-4-SG } \\
& 1 \text { - Bldg. } 324 \text { - DFT-956-10-CH } \\
& 1 \text { - BIdg. } 324 \text { - DFT-957 } \mathrm{HB} \\
& \text { I - Bldg. 324 - DPT-957-AL } \\
& 1 \text { - Bldg. } 324 \text { - DPT-956-9-IIC } \\
& 1 \text { - Bldg. 324 - DPT } 953-\mathrm{AL} \\
& \text { I - Bldg. 324 - DPT-953-F } \\
& 1 \text { - Bldg. } 324 \text { - DPT-953-P } \\
& 1 \text { - BIdg. } 324-D P T=956 \% 7 \% 0 G
\end{aligned}
$$

76.2 PRESSURE INDICATING CONTROLIERS

Quantity -12

Range -3 to 15 psig

Input $=3$ to 15 psig air

Dial - Nominal $3 \mathrm{I} / \widehat{c}^{\prime \prime}$ diameter graduated 0 to 0.5 inches water

Modes - 1 to 100 proportional band, with 0.1 to 5.0 minutes reset. Output - 3 to 15 psig air

Air Supply - 20 psig

Gauges - 0 to $30 \mathrm{Lb}$. gauges to indicate supply and output pressure Accuracy - $1 \%$ at midale of scale 
76.2 PRESSURE INDICATING CONTROLIERS

Sensitivity - Less than 0.1 of $1 \%$ of full scale at $100 \%$ proportional band.

Control Action - Reversible in the field from direct to reverse Mounting - Surface

Connections - Standard $1 / 4$ " female NPT

Representative Type - United States Gauge Co., Catalog 505, or approved equal.

$$
\begin{aligned}
& \text { Mark - I - BIdg. } 324-\text { PIC 956-4mSG } \\
& \text { I - Blag. } 324 \text { - PIC 957-M } \\
& 1 \text { - BIdg. } 324 \text { - PIC 957-AI } \\
& \text { I - BIdg. } 324 \text { - PIC 956-2-HB } \\
& 1 \text { - BIdg. } 32 i^{4}-\text { PIC 957-P } \\
& 1 \text { - BIdg. } 324 \text { - PIC 957-IB } \\
& 1 \text { - BIdg. } 324 \text { - PIC 953-AI } \\
& 1 \text { - BIdg. } 324 \text { - PIC 953-F } \\
& \text { I - BId̃g. } 324 \text { - PIC 953-P } \\
& 1 \text { - BIdg. } 324 \text { - FIC 956-7-OG } \\
& 1 \text { - BIdg. } 324 \text { - PIC 956-10-CH } \\
& 1 \text { - BIdg. } 324 \text { - PIC 956-9-LIC }
\end{aligned}
$$

\section{GALVANIZED DUCT MATERIALS}

a. Galvanized steel sheets, bars, roỏs, and shapes shall conform to the requirements of Hanford Standard Specification HWS-7508-S.

b. Cadmium plated bolts, studs and nuts shall be electrodeposited cadmium coating on carbon steel conforming to ASTM A307, Grace A, and ASTM A165, Type NS. Bolt heads and nuts shall be hexagonal heavy series. Flat vashers vill be standard plain conforming to dimensional standards of ASA B27.2 and coated in conformance ilth ASTM AI65, Type NS. 
77. GALVANIZED DUCT MATERIALS (continued)

c. Solder used on galvanized steel shall conform to ASTM EJ2, Grade 50A.

d. Tinners rivets shall conform to ASA B18.1.

e. Gaskets stall be 1/8" neoprene as specified in HWS-7508-S.

78. ALUMINGM DUCT MAIERIAIS

a. Aluminum shest and plate shall conform to ASTM E209, AII0y 6051, Temper T4 or T6.

b. Aluminim shapes, bars and rods shall be rolled alumirum corforming to ASTM, E308, Alloy 6061, Temper TE.

c. Aluminum pipe shall be of the sizes and weights shown on tire araw ings and shall conform tc ASTM B241, Alloy 6061, Temper T6.

d. Neoprene for gaskets and bolting materials for flanged joints shall conform to the requirements stated in HWS-7508-S.

79. DUCT TAFE

a. Adhesive backed tape for sealing ducts shall be six mil thickness; aluminum colored, fleme resistart, vinyl tape as manufacture 2 by Minnesota Mining and Mamufacturing Co., No. 474, Type VFU, or approved equal.

b. Polyethylene adhesive tape for sealing polyetiylene covering on stainless steel ducts exposed to earth backfill shall be 20 mils (0.020") thick and shall be "Polyken" No. 920, or approved equal.

80. STAINLESS STEELL DUCT MATERIALS

a. Stainless steel plates, shapes and bars for use in weldments shall be austenitic 18-8 AISI Type 304I conforming to ASTM AI67, Grade 3 and A276. Maximum carbon content shall be 0.035 per cent.

b. Stainless steel plates, shapes and bars not included in weldments shall be austenitic 18.8 AISI Type 304 conforming to ASTM A167, Grade 3 and $A 276$.

c. Stainless steel sheet shail be austenitic 18.8 AISI Type 304 can= forming to ASTM AI67, Grade 3, except that stainless steel to be used in weldments shall be Type 304L with a maximum carbor content of 0.035 per cent. Stainless steel sheet will be furnished with a $2 B$ finish conforming to ASTM AI67.

d. Stainless steel bolts, studs, and welding studs shall be austenitic 18-8 AISI Type 304 conforming to ASTM A320, Grade B8. 
80. SMAINTESS STEEI DUCM MATERIAIS (Continued)

e. Stainiess pipe for ducts shall be Type 304I conforming to the requirements of ASTM A3I2.

81. ASBESTCS CEMENT DUCT MATERIEIS

a. Asbestos-cement underground ducts shali be pressure formed pipe, Johns Manvilie Co. "Trans te Sever Pipe", Class 4000, or affroved equal. Joints end couplings shall be J-M "Ring-Tite", or approvel equal.

b. Wye branch fittirgs and elbows shali be commercial sewer fittings of the same metexial and strength as the pipe, or they may be Joins-Manvilie abestos cement Fume Dict, or approved equil. fittings encesed in struajure concrete witi a minimum thickisss of 6 inches ali around. Ëbow fittings, 90 degrees or less, shail be formed or witered and censted to deveiop full strength of the pipe at tre berd.

\section{DUCT ITNER}

a. Duct iner material for sound and themal insulation of the suppiy duct over the roof of the building chall be $2^{\prime \prime}$ thick rigid glass fiber msteriai rith a density not greater than 6 ib. per cubic foot. The materid shail ke costed with neoprene or viny. spray on the side exposed to the sir flow to prevent erosion of the giass fibers.

b. Acoustical lining for ducts and pienums inside the building, whers Iinirg is specified on tise arawings, ehall be rigid gibss fizer bosrd one inch thick and veighing approximately 18 pef. The face exposed to the air siresm shsil be coated with neoprene or vinyi to prevent erosion of the fibere. Acoustical duct liner, when tested in a No. 6 mounting as shown in Bulletin XXII, 1962. of the Acoustical Msieriais Association, shail have absortion coefficients not less than the following:

Frequency-ors

Absorption coefficient

Acoustisal duct lining shaiti be eohns-Manvilie Co. "Airacoustis" Duct liner, or approved edusl.

c. Fasteners to hold the inner in fiace shall be Miracle Adhesives Corp. Fronged anchors or 5Findie ara masher fasteners, or approved equal.

d. Insuration sdhesive for use with thermin and scoustical dinct inings shali be a fire resistive, trowei grale material which wil solere giass fiber materials to gabranized or girrinum metal surfices. Insuation ajhezive shais be Benjamin Foster Co. No. 8i-60, Fine Resist:ve Adresive, or approved equai. 
83. PVC LINED DUCT

Exhaust duct for future etch tank (Eee draving $(\mathrm{H}-3-20201$ ) shall be lined with an elsstic sheet lining formed from high molecular weight polyvinyl chloride resins compounded with stabilizers and chemically resistant plasticizers. Iining shall be Kaykor Industries, Inc。

"Vyfiex L-IO", or approved equal.

84. VENTTIATION SYSTEM ACCESSORIES

a. Turning vanes for elbows with equal upstream and downstream legs shall conform to the requirements of Hanford Standard Specification HWS-7508 0

b. Right angle elbows having upstream and downstream legs of unequal depth shall be equipped with 18 gsuge splitters riveted to the duct: with a minimum of 3 rivets at each end. The upstream edge of each splitter shall be turned back a minimum of $1 / 2$ inch. The number of equally spaced splitters shall be as follows:

Smaller duct width

Number of splitters

$$
\begin{array}{cc}
0 " \infty 8 " & 9 "-18 " \\
2 & 3
\end{array}
$$$$
3
$$

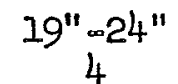

4
25 " \& over 5

c. Dampers, operators, quadrants, fire dampers and stationary louvers shall be as specified herein.

85. SEATING COMPOUNDS

a. Wherever caulked seams and joints are called for on the drawings the material used shall conform to the requirements of Federal Specification TTळC 598, Grade 2 (knife grade)。

b. Wherever sealants or sealing compounds are specified on the drawings for sealing joints in metal panels the msterial used for this purpose shall conform to the requirements of ASA AII6.1:

\section{WORKMANSHIP}

86. DUCTWORK

86.1. GENERAI

8. Dust supports are shown on drawings $\mathrm{H}-3-20287,88,89$ and 90 .

b. Where turning vanes are located in duct elbows having a diagonal dimension between $18 "$ and $36^{\prime \prime}$, a onewinch angle stiffner shall be riveted to the top and bottom of the duct for reinforcement. Where elbow diagonal dimension is greater than $36^{\prime \prime}$ a $1.1 / 2^{\prime \prime}$ angle shall be used. 


\subsection{GAIVANIZED DUUTWORK}

a. All ductwork above grade shall be galvanized steel except as specified otherwise herein or shown otherwise on the drawings.

b. Galvanized ductwork shall be constructed in accordance with the requirements of Hanford Standard Specification HWS-7508 $\mathrm{m}$.

c. Supply ductwork to Room 139 shall be 2 points heavier and bracing speced at haif the span shown in the chart for ga.Ivanized ductwork shown in HWS-7508 as.

\subsection{ALUMTNUM DUCTWORK}

a. The following items of ductwork shall be aluminum.

(1) Cold Canyon supply and exhoust.

(2) Low Level Canyon exhaust.

(3) Zone III exhaust stacks.

b. A1I aluminum duct material gauges and joining methods shall conform to the following tabuiation. Bracing and flanges on aluminum duct shals be eliminum. Bolting materials shall be cadmium plated steel. Rivets shall be aluminum. Sheet metal screws shall not be used in aluminum duct.

\section{ALUMTINUM DUCTWORK}

\begin{tabular}{|c|c|c|c|}
\hline $\begin{array}{l}\text { Aluminum } \\
B \text { \& } 5 \\
\text { Gage }\end{array}$ & $\begin{array}{l}\text { Maximum } \\
\text { Side } \\
\text { Inches }\end{array}$ & $\begin{array}{l}\text { Type of Transverse } \\
\text { Joint Connection }\end{array}$ & Bracing* \\
\hline 22 & Up to 12 & $\begin{array}{l}\text { S. Drive, Pocket or Bar Silp, } \\
\text { on } 7^{\circ} \text {. } 10^{\prime \prime} \text { centers }\end{array}$ & None \\
\hline \multirow{2}{*}{20} & 13 to 24 & $\begin{array}{l}\text { S, Drive, Pocket or Bar Slip, } \\
\text { on } 7^{\circ} 10^{\prime \prime} \text { centers }\end{array}$ & None \\
\hline & 25 to 30 & $\begin{array}{l}\text { S, Drive, }_{2}{ }^{\prime \prime} \text { Pocket of } I^{n} \text { Bar } \\
\text { Silps on } 7^{0} \text { - }{ }^{\prime \prime} \text { centers }\end{array}$ & $\begin{array}{l}1^{\prime \prime} \times 1^{\prime \prime} \times 1 / 8^{\prime \prime} \\
\text { angles } 4 \text { ft. } \\
\text { from joint }\end{array}$ \\
\hline \multirow[t]{2}{*}{18} & 31 to 40 & $\begin{array}{l}\text { Drive, } l^{\prime \prime} \text { Pocket or } I^{\prime \prime} \text { Bar } \\
\text { SIips, on } 7^{\circ} \text { " } 10^{\prime \prime} \text { centers }\end{array}$ & $\begin{array}{l}I^{\prime \prime} \times I^{\prime \prime} \times 1 / 8^{\prime \prime} \\
\text { angles } 4 \text { ft. } \\
\text { from jolnt }\end{array}$ \\
\hline & 41 to 60 & $\begin{array}{l}\text { 1.1/2" Angle Connections, or } \\
\text { l-1./2" Popket, or } 101 / 2^{\prime \prime} \text { Bar } \\
\text { slips with } 1 \text { w/8 } 3 / 8^{\prime \prime} \times 1 / 8^{\prime \prime} \text { bar } \\
\text { reinforcing on } 7^{\circ}=10^{\prime \prime} \\
\text { centers }\end{array}$ & $\begin{array}{l}1-1 / 2^{\prime \prime} \times 1-1 / \sum^{n} \\
x i / 8^{\prime \prime} \text { angle } L \\
\text { ft. from jole: }\end{array}$ \\
\hline
\end{tabular}




\subsection{ALNMTNIM DIJCIWORK}

b. (Continued)

\begin{tabular}{|c|c|c|c|}
\hline $\begin{array}{l}\text { AIuminum } \\
B \text { \& } S \\
\text { Cege }\end{array}$ & $\begin{array}{l}\text { Maximum } \\
\text { Side } \\
\text { Inches }\end{array}$ & $\begin{array}{l}\text { Type of Iransverse } \\
\text { Joint Connection }\end{array}$ & Bracing* \\
\hline 16 & 61 to 90 & 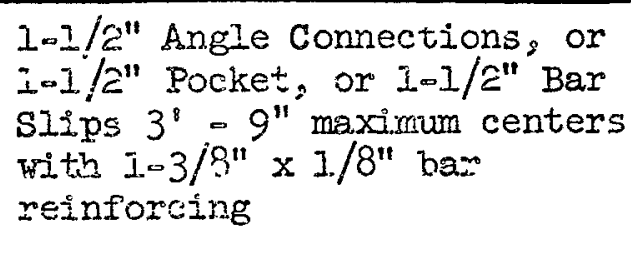 & 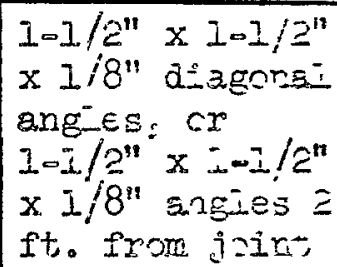 \\
\hline
\end{tabular}

*Bracing may be omitted when maximum length of duct section tabulated above is reduced by one-half.

c. Aluminum ductwork shali be constructed as specified in HWS-7508-S for stee. ductwork, except that the materiais specified herein shanl be used.

\subsection{STAINLESS STEEI DUCTWORK}

a. Exhaust ductwork from the laboratory, Hot Pilot cells and the Metailurgican Celis shall be Type 304I stainless steel except where shown otherwise on the drawings.

b. All stainless steel ductwork shall be welded. Welding process shais be inert-gas-shielded-tungsten-are, for material thinner than 10 gauge. For materians 10 gauge and heavier the welding process usea shall be the same as specified above or inert-gasmshielded-metal-ars.

c. Stainless steel ducts shali be sealed in a double wrap of polyethylene sheeting where exposed to earth backfil?. Backfill materibl shal: be sand and shall be flaced and compacted by hand to an elevarion of 6 inches above the top of the duct to avoid puncturing the pisstic sheet. Punctures or cther damage to the plastic covering shai: be repsired with polyethyiene adhesive tap

87. TNSTA I.TA TEON OF DICT IINER

a. Inot acoustical Iiner material, one inch in thickness, shall be installe $\lambda$ in supply ducts and pienums inside the building where show on the drawings. The ducr thermal insulation liner thickness, in the supply duct above the roof of the building, shail be 2 inches. 
87. INSTALIATION OF DUCT LINER (Continued)

b. Adhesive based pronged anchors or spindles shall be adhered to the top, bottom and sides of the interior of the duct on 16 inch centers in each direction. Liner material shall then be impaled on the anchors or spindles and the prongs or washers pushed down until the face of the liner material is dimpled.

c. The upstream edges of pieces of duct liner shall be buttered with fire resistive adhesive and the pieces butted together. Breaks in the liner facing, such as gouges, abraded spots, etc., shal 1 be troweled with a coat of the adhesive.

88. SUPPIY UNIT CASING

In addition to the data listed in specification HWS-7508 S $_{\text {, the }}$ following shall apply。 Casing shall be attached to a $11 / 2^{\prime \prime} \times 11 / 2^{\prime \prime}$ $x 1 / 8$ " angle (minimum) with rivets 12 " on centers (minimum). The angle shall be attached to the curb with castwin anchor bolts or expansion bolt anchors $12^{\prime \prime}$ on centers minimum. Access doors, located as shown on the drawings shall be a minimum of 22 inches wide by 6 feet high. Clezrance between casing and inlets of fans EFN 901 and 902 shall be a minimum of $2 / 3$ the wheei diameter.

89. TESTING AND BAIANCING

a. Balancing of the ventilation system shall be done as specified in Hanford Standard Specification HWS-7508-S. All interior and exterior doors shall be closed during balancing.

b. Additional testing of the ventilation systern will be required, as specified in Appendices " $A$ " and "B" to this specification, prior to acceptance of the system and it ${ }^{\circ}$ s components by the Commission.

c. Ventilation system balancing may be done coincidentally with heat run for electric fan motors specified in Division XVII.

d. AlI testing shall be done in the presence of the Commission. The Commission shall be notified at least 5 working days before testing is to begin.

90. IDENTIFICATION OF EQUIPMENT

a. All equipment, except grills and registers, identified in this diviaion by equipment piece number (FFN) shall have the name and equipment piece number painted on the equipment. Block characters; varying in height from $1 / 2^{\prime \prime}$ to 2 " shall be used. Where equipment such as fans, heating coils, air washers, etc, are installed inside 


\section{a. (Continued)}

housings, the identification shall be placed on the outside of access doors leading to the equipment.

b. The paint used for identification legends shall be gloss enamel of the type specified in Division XVI of this specification. Black enamel shall be used on gray and other light backgrounds and white enamel on biack or dark backgrounds.

\section{STORAGE AND INSTALLATION OF FILTER UNITS}

a. The high efficiency filters are fragile and extremely susceptible to damage. Care in handling and installation is essential.

b. After testing by the Commission is completed, the Contractor shall place the medium and high efficiency filters in closed storage where they will be protected from the weather until time for installation. Filters shall remain sealed in the original containers while in storage. Filters placed in storage shall be stacked in compliance with the "This Side Up" label on the container and not more than five units high.

c. The medium and high efficiency filters shall not be installed until the work of all other crafts, inside the building, has been completed and the building has been thoroughly cleaned. The entire interior of the building shall be broom clean, and in addition, the interiors of the process cells, operating galleries, tank vaults and exhaust tunnels and ducts, upstream of the filters, shail be vacuum cleaned prior to installation of filters. Vacuum cleaning shall proceed from the extremities of the system toward the exhaus $t$ fans. Tunnel between the fans and the exhaust stack shall be swept clean with a broom.

d. When filters are removed from the containers for installation, the container shall be lifted off the filter rather than the filter being lifted from the container. 


\section{DIVISICN XI}

STANDARD DOORS, WINDOWS AND HARDWARE

GENERAL

\section{SCOPE}

This division covers windows, standard sized pedestrian doors, power opersted: vertical lift and swinging industrial doors and power operated roll-up dcors for the Fiels Recycle Pilot Plant, Building 324. Shielding doors and cell crane doors are covered in Division XII.

\section{REFERENCED STANDARDS AND SPECIFICACIONS}

The standards and specifications listed below form a part of this specifiazticn to the extent indicated by subsequent references.

\subsection{FEDERAL SPECIFICATIONS}

$$
\begin{aligned}
& \text { DD-G-45la - Glass, Flat and Corrugated, For Glazing, } \\
& \text { Mirrors and Other Uses }
\end{aligned}
$$

FF-H-106a(6) - Harłware, Builders; Locks and Door Trim

FF-F-O0llib - Hardware, Builders; Shelf and Miscellaneous

$\mathrm{FF}-\mathrm{H}-1 \mathrm{I6c}(2)$ - Hinges, Hardware, Builders

FF-H-12le - Harōware, Builders; Door-Closing Devices

HH-I-562 - Insulation, Thermal, Mineral Wool, Block or Bcard

\subsection{AMERICAN STANDARDS ASSOCIATION (ASA)}

A.SA Al15.I - 196I Door and Frame Preparation for Mortise Door Locks

\section{MATERIALS}

3. HOLLOW METAL SWINGING DOORS (STANDARD SIZES)

a. Hollow metal doors shall be formez from minimum 18 gauge steel furniturs stock. Steel shall be stretcher-leveled, fully pickled and annealed. All surface welds shall be ground smootr.

b. Doors shall be constructed and braced inside with sufficient steel reinforcing to prevent sag or warp. Doors shall be reinforced at all sinkages and at locations where hardware is to be attached in order that. hardware can be attached with machine sarews without altering docrs in the field. Doors shall be fitted for template hardware.

$$
-175-
$$


3. HCLIOW METAL SWINGING DOORS (STANDARD SIZES) - Continued

c. Hollow cores of doors shall be filled with a sound deadening material. Dcors shall be of the types and sizes shown on drawing H-3-20171, 20172 and 20173 .

d. Hollcw metal fire doors, types $M$ and $N$, shall be filled with an incombuatible material and shall be rated as $1-1 / 2$ hour, Class $B$ Fire Dcors. Fire doors shall bear the Underwriters Laboratories labels showing the name of the door manufacturer and UL classification stamp. Fire doors shall be capable of withstanding a uniform load of $60 \mathrm{lb}$. per square fcot with a safety factor of 3 .

e. Hollow metal swinging doors, except doors No. 101 and No. 140 , shall be furnished with a coat of metal-protective primer and baked enamel finist paint. Glazed doors shall be fumished with continucus glazing bead and metal moulding ic hold glass in place. Finish color of doors shall be as shown on drawing H-3-20175.

f. Docrs No, 6 through No. II, and hardware for same, shall be capable of withstanding a uniform load of $55 \mathrm{lb}$. per square foot acting in the direction away from the stop with door closed.

g. Louvers for doors shall have $81.5 \%$ free area.

h. Doors to be lised in rolled strustural channel frames shall be dapped for hinges to a depth sufficient to accept both leaves of the hinges.

i. Cutouts for door locksets shall conform to ASA 115.1.

j. Dcors shall be products of M. Reuter \& Sons Metal Products Co.; Ceco Steel Prcducts Co.; Overly Manufacturing $C_{0}$, or approved equal.

4. FRAMES FOR EOLLOW METAL SWINGING DOOES

a. Pressed steel frames for hollow metal swinging doors shall be format from fuxniture stcck steel not lightex than 16 gauge. Corners shall be miterea, eleotric welded and ground smcoth to produce an invisible joint.

b. Jambs of pressed steel frames shall have nct less than 3 anchoring devices per jamb. Jambs shall be reinfcreed for attachment of template hinges. Heads shall be reinforced for attashment of door closers. .

c. Pressed steel door frames shall be furnished with a coat of baked-on, metal protective primer.

d. Rolled structural steel shapes used for door frames shall conform to the same requirements for material and shop priming as specified for builiing framing in Division IV.

$$
-176-
$$

HWS -5967 
4. IRAMES FOR HOLLOW METAL SWINGING DOOES - Continued

8. Cutcuts for lock strikes shall conform to the requirements of ASA AII5.I.

5. ENTRANCE PANEL

Door No. 101 shall be hollow metal, steel construction with $3^{\prime \prime}$ stiles and top rail and 6" bottom rail. Entrance panel shall have fixed, glazed sideligkt as shown on drawing H-3-20182. Door No. 140 shall be the same as door No. 101, except without side light. Both doors shall conform to the requirements stated in Section $3 \mathrm{a}, \mathrm{b}$, \& $c$ above, Metal parts of docrs and framizg shall be Overly "Colorelad" No. 1109 satin aluminum finish. Entrance panel shall be Overly Manufacturing Co. "Overline" entrance panel, or approved equal.

\section{WISDCW AND DOOR GLASS}

9. Wred glass for fire doors shall be $1 / 4$ inch thick, polished glass containing welded wire mesh not smaller than $7 / 8$ inches, formed from wire nct smaller than 24 B\&S gauge. Wired glass shall conform to the requirements of Federal Specification DD-G-45la, Type IIIa. Mississippi Glass Co. "Misco" is a representative type.

b. Glass for entrance panel doors and sidelight (No. 101 \& 140) and typa F, $G$ and $B$ windows shall be $1 / 4$ inah thick polished plate glass conforming to the requirements of Federal Specification DD-G-45la, Type I, glazing quality.

o. Glass for interior doors shall be flat drawn sheet, double strength, grade B glass, conforming to Federal Specification DD-G-45la, Type II.

d. Giass for type B windows shall be $7 / 32$ inch thick pattern glass (unpolished on back side) conforming to Federal Specification DD-G-45la, Pype III, Pattern Class IV. Libby-Owens-Ford "Small Glacier" is a" representative pattern.

e. Glass for type $K$ windows shall be $1 / 4$ inch thick polished plate glass conforming to Federal Specification DD-G-45la, Type I, which in addition Las been heat-tempered for greater strength. Libby-Owens-Ford "Tuf-flex" is a representative type.

f. Glass for types $A, C, D \& E$ windows shall be $3 / 16$ inch thick, flat drawn, heary sheet glass, Grade B conforming to Federal Specification DD-G-45Ia, Bype II.

\section{WTSDSN SCREENS}

a. Where shade screens are shown on the drawings, the screening shall be formed irom type 5052 aluminum sheet or bronze. The screen shall have vertical rows of horizontal louvers (approximately 17 per inch of height). 


\section{WINDOW SCREENS - Continlied}

b. Shade screens shall be provided with a positive latching device and hinges to permit the frame to be swung to one side for window cleaning. Scresns shall be attachel to the screen frames in a manner to prevent rattling:

c. Stade screens shall be Kaiser Aluminum \& Chemical Corp. "Shade Screen"; Warp Bros. "Venetian Screen"; Reflectal Corp. "KoolShade"; or approved equal.

\section{WELDTNC CURTAIN}

a. Curtain to close off the welding booth shall be woven glass cloth impregnated with neoprene. Top edge of cloth shall have $1 / 2$ brass grommets fastened in the cloth 10 inches center to center.

b. Track shall be a channel type, Unistrut P-1000, or approved equal.

c. Curtain carriers shall be steel with nylon wheels and shall be equipped with eye bolts for hanging the curtain. Carriers shall be Unistrut. $P=2749$, or approved equal.

d. Curtain hooks shall be chrome plated brass, heavy duty type.

e. Welding curtain shall be Standard Safety Equipment Co. "Sta-Safe" Welding Curtain, or approved equal.

\section{WINDOWS}

a. Windows shall be single light, fixed steel sash of the sizes and frame types shown on drawing $\mathrm{H}=3-2018 \mathrm{e}$.

h. Frames shall be modified $\mathrm{z}$ bars formed from hot rolled new billet steel. corners of frames shall be coped or mitered and electrically welded. Icints and welds skall be ground smocth.

c. Window sash shall be hot-dip galvanized, bonkerized and shop primed with a baked-on coat of metal protective paint.

d. All windows, except Type $J$, shall be designed for glazing from the cutside Fith spring wire glazing clips and steel-window putty.

e. Window Type $J$ shall be furnished as a sidelight in entrance panel with door No. 101. Window Type I shall be designed for glazing from the outside with continuous glazing bead flirnished by the door manufacturer (See Section 5, this division). 


\section{WINDOWS - Continued}

f. Windows shall conform to the requirements of the steel Window Institute specifications for $11 / 2$ inch Heavy Intermediate Steel Windows and the requirements stated herein and on the drawings.

\section{VERTICAL LIFT DCORS}

a. Vertical lift doors shall be rigid, hollow metal power operated, steel doors and shall be of the height and width shown on the drawings.

b. Vertical lift doors shall be of all welded construction and shall have suficieient strength and rigidity to withstand a uniform load of 20 psf without deflecting more than $1 / 240$ of the span.

c. Doors and guides shall be furnished with a prime coat of baked-on metal protective paint applied by the manufacturer.

d. Docrs shall be counter-welghted and operated with a power-winch and cable as indicated on the drawings. Motors shall be wound for operation on a 440 volt, 3 phase, 60 cycle, power supply. Doors shall be equipped with limit switches to stop travel at fully open and fully closed positions. Rate of door travel shall be approximately one foot per second. Counterweight cover shall be full height of counterweight travel.

e. Doors in exterior walls shall be equipped with automatic latch bolts (2 per door) which would prevent entry from the outside when the door is in the closed position. Iatch bolts shall be automatically retracted when the power operator is energized.

f. Doors No. 106, 111 and 112 shall be filled with insulating material conforming to Federal Specification HH-I-562, Type I, Class 1 or 2 . Insulation shall be effective over the full height and width of the opening. This requirement shall include the pedestrian door incorporated in door No. 106.

g. Door structural framing shall be rolled structural steel members or rectangular steel tubing. Doors shall be faced on both sides with sheet steel not lighter than 14 gauge.

h. Vertisal lift docrs shall be Richards-Wilcox style No. 873 or No. 876, or approved equal.

11. ROLL

a. Dsors 10, 2, 171, $174 \& 324$ shall be steel curtain, power operated, rollup daors of the sizes shown on the drawings. Doors in exterior walls shall se designed for mounting on the inside face of the wall. 


\section{ROLLUP DOORS - Continued}

b. Roll-up doors shall be capable of withstanding a uniform loading of 20 psf without deflecting more than $1 / 240$ of the span. Curtain slats shall be provided with end lugs to hold the curtain in the guides and shall be designed to provide for a minimum of leakage of air past the door.

c. Slats, guides, bottom bar and roller housing (hood) shall be galvanized (not less than $1.25 \mathrm{oz}$. coating class) and phosphate treated, to recelve paint in the field.

d. The curtain roller shall be of sufficlent strength and rigidity to hold the welght of the curtain and its attachments without deflecting rore than .03 inches per loot of opening width. Roll-up doors shall be counterbalanced and provided with counterbalance adjustment, outside the hood, so that the door can be adjusted for éase of emergenoy manual operation.

e. Doors shall be provided with power operator and also a hand chain for manual operation on loss of electric power. Motor shall be wound for operation on 440 volt, 3 phase, 60 cycle power supply. The doors shell be provided with limit switches to stop the power operator when the door curtain reaches fully open and fully closed positions. Doors shall be furnished with constant pressure push-button control stations requiring continuous pressure on the push-buttcn to maintain docr travel. Push button stations shall be fitted for wall mounting inside the building. Power operator shall be capable of cperating the door at a rate of approsimately one foot per second.

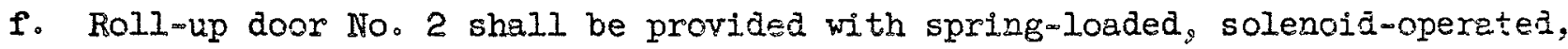
latch bolts which will effectively prevent entry through the door from tie outside when the door is closed. Solenoids shall bold the latch bolts retracted at all times when the power operator is energized. The latch bolts shall be accessible for manual retraction in case of loss of electrie power.

g. Rolling doors shall be Kinnear Manufacturing Co. Rolling Service Doors, or approved equal.

12. IARGE HOLLOW METAL SWINGING DOORS (NO. 176)

a. Doors No. 176 shall be a pair of hollow metal, power operated, swinging doors. Doors shall have a frame of rolled structural steel shapes, faced on both sides with steel sheets. Face sheets shall be stretcher-leveled furniture stock, fully pickled and annealed. Doors shall be of all-welded construction with all visible welds ground to 125 finish. T-style kinges shall be used. 
12. IARGE HOLLOW METAL SWINGING DOORS (No. 176) - Continued

b. Power operators shall be capable of operating the doors from closed position to full open in 7 to 10 seconds. Power operator motor shall be wound to operate on a 440 volt, 3 phase, 60 cycle power supply. Power operatcrs shall not extend above the top of the doors.

c. Doors shall be equipped with automatic door bottoms and shall be weatherstripped as indicated on the drawings.

d. Doors shall be furnished with a factory-applied, baked-on coat of metal protective primer paint. Doors shall be Richards-Wilcox Mfg. Co. Style RuW No. 876, with R-W No. 434-B Hinges or approved equal.

\section{DOOR SILIS AND WEATHERSTRIPPING}

a. Door thresholds and weatherstripping shall be of the types shown on drawing H-3-70I72。

b. Door threshold Type "S" shall be extruded aluminum with fluted tops, approximately 4" wide and 1/2" high, Chamberlin No. 912, Sager No. 634, Zero No. 65 , or approved equal.

c. Door threshold Type "Y" shall be extruded aluminum, 5/8" high and 3 " to $31 / 2$ " wide with compressible vinyl or rubber bump strip, Chamberlin No. $\mathrm{CF}-150$, Dura-Flex No. RB 150, Sager No. 76 , or approved equal.

d. Automatic door bottoms, shown for "R", "S" \& "W" type sills, shall be fully mortised type, with sponge neoprene strip, operated by plunger contact with door jamb, Chamberlin No. 424-A, Zero No. 36-H, or approved equal.

e. Weatherstripping for heads and jambs shall be sponge neoprene with aluminum housing. Type "A" as shown, shall be Zero No. 140 or approved equal. Type " $B$ " shall be Zero No. 50A, or approved equal.

f. Weatherstripping for door sills Types "T" and " $U$ " shall be aluminum mounted vinyl or neoprene strip projecting $5 / 8$ " to $3 / 4$ " for hollow metal doors, Accurate No. 152, Chamberlin No. 90, Zero No. 52S, or approved equal.

g. Roll-up doors shall be provided with weatherstripping to restrict the passage of air between zones where a differential in air pressure exists. Weatherstripping at door bottoms shall be an extruded strip of sponge neoprene or rubber, or a hollow vinyl strip. 


\section{DOOF. HAFDWARE}

a. Door hinges for pedestrian doors shall conform to the requirements of Federal Specification HH-F-116c (3) Type T2107 with US 10 finish except hinges for Type $K$ docrs shall be satin aluminum finish. Hinges shall be furnished in the sizes indicated in the Hardware Schedule. Hinges for fire doors, Types $M$ and $N$, shall be formed from material not less than 0.135 inches thick. Hinges for doors with cylinder locks shall have non removable loose pins.

b. Iocksets, for swinging doors not more than 8 feet in height, shall conform to Federal Specification HH-F-106a(6) and shall be of the types shown in the Fardware Schedule. Latch bolts for locks on active leaf of $N$ type doors shall have 3/4" throw. Latch bolts for Series 86 locks and latches shall be anti-friction type. Door knobs shall be Type 201G. Knobs and roses shall be plain design US 10 finish except for Type $K$ doors which shazl be US 28 .

c. Door elosers shall conform to the requirements of Federal Specification HH-F-i2lo, and shall be of the types shown in the Hardware Schedule, with bronze lacquer finish.

d. Door stops and cremone bolts shall conform to the requirements of Federal Specification HH-F-OOlllb, and shall be of the type specified in the Hardware Schedule, with US 10 finish.

e. Exit deviaes shall have US 10 finish and shall conform to the requirements of Federal Specification HH-F-106a. Locks for use with exit devices shall be mortise type with latchbolts having a 3/4" throw. Inactive door of pairs shall have as a minimum: $1 / 2$ " vertical rods with $5 / 8$ " hinged bolts having a $5 / 8$ " throw.

f. Dcorpulls and pushplates, except for doors 101 and 140 , shall be 14 " X $31 / 2 "$, wrought bronze, US 10 finish, except where stainless steel, US 3ED finish, is specified in the Hardware Schedule. Doorpulis and plishplates, with the above exceptions shall conform to the requirements of Federal Specification HH-F-106a.

5. Pressure release devices for doors 185 and 258 shall be spring 1oaded, adjustable, cam type devices as produced by the William Bayley Co., No. $\mathrm{H}-24$, or approved equal. 
HARCWARE SCHEDULE

\begin{tabular}{|c|c|c|c|c|c|c|c|c|c|c|}
\hline Door Nn & Hinges & Lockset & Latsbset & $\begin{array}{l}\text { DWARE ST } \\
\text { Exit } \\
\text { Device }\end{array}$ & $\begin{array}{l}\text { DUIE } \\
\text { CIoser }\end{array}$ & Stop & $\begin{array}{l}\text { Cremone } \\
\text { Bolt }\end{array}$ & $\begin{array}{l}\text { Push- } \\
\text { Plate }\end{array}$ & Pulls & Remarks \\
\hline $\begin{array}{l}1,102,103,105, \\
107,109,120 \& 302\end{array}$ & $4 \frac{1}{2} \times 4 \frac{1}{2}$ & & & $820 \mathrm{~K}$ & $3001-4 P$ & & & & & \\
\hline $3,4.85$ & $4 \frac{1}{2} \times 4 \frac{1}{2}$ & $86.5=5$ & & & $3001-4$ & & & & & \\
\hline 6 & $4 \frac{1}{2} \times 4 \frac{1}{2}$ & $865=5$ & & & 3001 . $14 \mathrm{H}$ & & & & & \\
\hline 7 & $4 \frac{1}{2} \times 4 \frac{1}{2}$ & $86 J-5$ & & & $3001 \div 4 \mathrm{~B}$ & $1328-E$ & & & & \\
\hline $8,11,12,311 \& 312$ & $4 \frac{1}{2} \times 4 \frac{1}{2}$ & & $86 N-5$ & & $3001-4 \mathrm{H}$ & $1328 \mathrm{E}$ & & & & $\begin{array}{l}\text { womon stop tor } \\
\text { No. \& } 11\end{array}$ \\
\hline $9.10 \& 13$ & $4 \frac{1}{2} \times 4 \frac{1}{2}$ & & $86 N-5$ & & $3001-4 \mathrm{H}$ & & & & & \\
\hline $\begin{array}{l}14,16,17,116,117 \\
213,249,303,320 \\
321 \& 327\end{array}$ & $4 \frac{1}{2} \times 4 \frac{1}{2}$ & & & $820 \mathrm{~K}$ & $3001-3$ & $1328 \mathrm{E}$ & & & & \\
\hline $15,164,165 \& 169$ & $4 \frac{1}{2} \times 4 \frac{1}{2}$ & & & $822 \mathrm{~K}$ & $3001-3$ & $1328 \mathrm{E}$ & & & & \\
\hline $12^{\prime}+205 \& 305$ & $4 \frac{1}{2} \times 4 \frac{1}{2}$ & & & $822 K$ & $3001-3$ & $1328 \mathrm{E}$ & & & & $\begin{array}{l}\text { leaf only. No } \\
\text { lonk cylinder } \\
\text { active leaf. }\end{array}$ \\
\hline 23 & $4 \frac{1}{2} \times 4 \frac{7}{2}$ & & & $822 A$ & $3001 \times 3$ & $1328 \mathrm{E}$ & & & & $\begin{array}{l}\text { Stop on LH } \\
\text { leaf only. }\end{array}$ \\
\hline 18 & $4 \frac{2}{2} \times 4 \frac{1}{2}$ & & $86 N-5$ & & $3001-3$ & $1328 \mathrm{E}$ & & & & \\
\hline 329 & $4 \frac{1}{2} \times 4 \frac{1}{2}$ & $86 \sqrt{-5}$ & & & $3001-3$ & $1328 \mathrm{E}$ & & & & \\
\hline 104 & $74 \frac{1}{2} \times \frac{1}{2}$ & & & 820 & $3001-4 \mathrm{P}$ & & & & & \\
\hline 109 & $4 \frac{1}{2} \times 4 \frac{1}{2}$ & & & $822 \mathrm{~K}$ & $3001-4 \mathrm{PH}$ & & & & & \\
\hline 115 & $1+\frac{1}{2} \times 4 \frac{1}{2}$ & & & & $3001-3$ & & & 465 & 455 & \\
\hline $\begin{array}{l}118,119,122,125, \\
118,170,172,182 \\
188,206,207,208, \\
210,214 \& 319\end{array}$ & $4 \frac{1}{2} \times 4 \frac{1}{2}$ & & & $820 \mathrm{~K}$ & $3001-3$ & & & & & \\
\hline
\end{tabular}




\begin{tabular}{|c|c|c|c|c|c|c|c|c|c|c|}
\hline Dror No & Hinges & Inokset & Iatchset & $\begin{array}{l}\text { Exit } \\
\text { Device }\end{array}$ & Closer & Stop & $\begin{array}{l}\text { Cremone } \\
\text { Bolt. }\end{array}$ & $\begin{array}{l}\text { Push- } \\
\text { Pligte- }\end{array}$ & Pinis & Remarks \\
\hline $123 \& 326$ & $4 \frac{1}{3} \times \frac{1}{3}$ & $86.5-5$ & & & & $1328 \mathrm{E}$ & & & & \\
\hline $\begin{array}{l}126,133,1+3, \\
149 \& 150\end{array}$ & $3 \frac{1}{2} \times 3 \frac{1}{2}$ & & $\begin{array}{l}\text { Corbin } \\
\text { No. } 7010\end{array}$ & & $3001-3$ & $1328 \mathrm{E}$ & & & & \\
\hline $\begin{array}{l}22.117,160,161, \\
163,177,184,\end{array}$ & $4+\frac{1}{2} \times 4 \frac{1}{2}$ & & & $\begin{array}{l}820 \mathrm{~K} \\
2 / 0 \\
\end{array}$ & $3001-3$ & $1328 \mathrm{E}$ & & & & \\
\hline 1.8152 & $-4 \frac{1}{2} x+\frac{1}{2}$ & & & & $3001-3$ & & & $7+65$ & 455 & \\
\hline 186 & $4 \frac{1}{2} \mathrm{X}+\frac{1}{2}$ & & $86 N-5$ & & & $1320 \mathrm{E}$ & & & & \\
\hline 130 & $3 \frac{1}{2} \times 3 \frac{5}{2}$ & & $\begin{array}{l}\text { Corbin } \\
\text { No. } 7010\end{array}$ & & & & $1028 \mathrm{~B}$ & & & $\begin{array}{l}\mathrm{RE} \text { leaf } \\
\text { active }\end{array}$ \\
\hline $\begin{array}{l}129, \sqrt{3} 6,137, \\
138,139,14, \\
157,223,224, \\
227,228,239, \\
231 \text { \& } 232\end{array}$ & $3 \frac{1}{2} \times 3 \frac{1}{2}$ & $\begin{array}{l}\text { Coxbin } \\
\text { No. } 7055\end{array}$ & & & & $1328 \mathrm{E}$ & & & & \\
\hline $\begin{array}{l}2+25,131 \\
31+8 \quad 317\end{array}$ & $15 \frac{1}{2} \times 4 \frac{2}{2}$ & 86.J-5 & & & $3001-3$ & & $1028 \mathrm{~B}$ & & & $\begin{array}{l}\text { LfH leaf } \\
\text { active }\end{array}$ \\
\hline $\begin{array}{l}132,1,310,310 \\
31 ? \times 38\end{array}$ & $4 \frac{1}{2} \times 4 \frac{1}{2}$ & $86 \mathrm{~J}=5$ & & & $3001-3$ & & & & & \\
\hline 135 & & & & & $3510-1$ & & & 465 & & $\begin{array}{l}\text { Pushplates } \\
\text { each side } \\
\text { each leat }\end{array}$ \\
\hline 142 & $3 \frac{1}{2} \times 3 \frac{1}{2}$ & & $\begin{array}{l}\text { Corbin } \\
\text { No. } 7010\end{array}$ & & $3001-3$ & & & & & \\
\hline $\begin{array}{l}16,153 \& \\
212\end{array}$ & $3 \frac{1}{2} \times 3 \frac{1}{2}$ & & $\begin{array}{l}\text { Corbin } \\
\text { No. } 7010\end{array}$ & & & & & & & \\
\hline 154. & $3 \frac{1}{2} \times 3 \frac{1}{2}$ & $85 E-5$ & & & $3001-3$ & & & & & \\
\hline $158 \& 250$ & $4=42$ & & & $822 K$ & $3001-3$ & $1328 \mathrm{E}$ & & & & \\
\hline $162 \& 318$ & $4+\frac{1}{2} \times \frac{1}{2}$ & $86 \mathrm{~J}-5$ & & & $3001-3 \mathrm{P}$ & $1328 \mathrm{E}$ & & & & \\
\hline 175 & $4 \frac{1}{2} \times 4 \frac{1}{2}$ & & & $\begin{array}{l}820 \mathrm{~K} \\
\text { w/o } \\
\text { cylinder }\end{array}$ & $3001-3$ & & & & & \\
\hline
\end{tabular}




\begin{tabular}{|c|c|c|c|c|c|c|c|c|c|c|}
\hline Door 18 & Fingos & Iockset & Latchset & $\begin{array}{l}\text { Exit } \\
\text { Devine }\end{array}$ & Closer & Stop & $\begin{array}{l}\text { Cremone } \\
\text { Bolt }\end{array}$ & $\begin{array}{l}\text { Push- } \\
\text { Plate }\end{array}$ & Fulls & Romarks \\
\hline $185 \& 258$ & $4+\frac{1}{2} \times 4+\frac{1}{2}$ & & & & & & & & & $\begin{array}{l}\text { Equip. both } \\
\text { doors with } \\
\text { adjustable } \\
\text { press rolease }\end{array}$ \\
\hline $213 \& 187$ & $4 \frac{1}{2} \times 4 \frac{1}{2}$ & & & 820 & $3001-4$ & & & & 459 & \\
\hline & $4 \frac{1}{2} \times 4 \frac{1}{2}$ & 86J -5 & & & $3001-4 P$ & & & & & \\
\hline $\begin{array}{l}201,248 \\
150\end{array}$ & $4 \frac{1}{2} \times 4 \frac{1}{3}$ & $86 G-5$ & & & $3001-3$ & $1328 \mathrm{E}$ & & & & \\
\hline 204 & $4 \frac{1}{2} \times 4 \frac{1}{2}$ & $86 G-5$ & & & $3001-3$ & & & & & \\
\hline $209 \& 215$ & $4 \frac{1}{2} \times 4 \frac{1}{2}$ & & & & $3001-3$ & $1328 \mathrm{E}$ & & 465 & 455 & \\
\hline $211,2^{\prime}+6 \quad \leq 47$ & $3 \frac{1}{2} \times 3 \frac{1}{2}$ & & & & $3001-3$ & $2328 E$ & & 465 & 455 & \\
\hline 251 & $4 \frac{1}{2} \times 4 \frac{1}{2}$ & & & & & & $1028 \mathrm{~B}$ & & & $\begin{array}{l}\text { Cremone bolt } \\
\text { both leaves }\end{array}$ \\
\hline 301 & $5 \times 5$ & & & & $3001-6$ & & $1028 \mathrm{~B}$ & & & $\begin{array}{l}\text { Cremone holt } \\
\text { rnth leaves }\end{array}$ \\
\hline 315 & $4 \frac{1}{2} \times 1+\frac{1}{2}$ & & $86 N-5$ & & & & $1028 \mathrm{~B}$ & & & $\begin{array}{l}\text { Cremone bolt- } \\
\text { inact,ive leaf }\end{array}$ \\
\hline 101 & $\begin{array}{l}\text { Corbin } \\
\text { No. } 7012\end{array}$ & & & & $3520-3$ & $1328 \mathrm{E}$ & & * & $\begin{array}{l}\text { Corbin } \\
\text { No. } 4379\end{array}$ & $\begin{array}{l}\text { RPushbar Fedo } \\
\text { Spec.FF-Ho } \\
\text { loba Type } 4 \text { 2A A }\end{array}$ \\
\hline 140 & \multicolumn{5}{|c|}{ Same as door No. 101 except. without lock } & & & & & $\begin{array}{l}\text { All hardware } \\
\text { for doors } 101 \\
\& 140 \text { to be US } \\
28 \text { satin alum- } \\
\text { inum. }\end{array}$ \\
\hline
\end{tabular}




\section{LOCK CYLINDERS}

a. Lock cylinders shall be Corbin No, 253 with keyway No. 67, masterkeyed as shown in the chart below. Lock cylinders shall be furnished with 3 keys per cylinder. The number "324" shall be etched or stamped on each key and on the face of each cylinder.

b. The system shall consist of 5 master systems, designated herein as $A, B$, C, D \& E, under grand master No. 1608G.

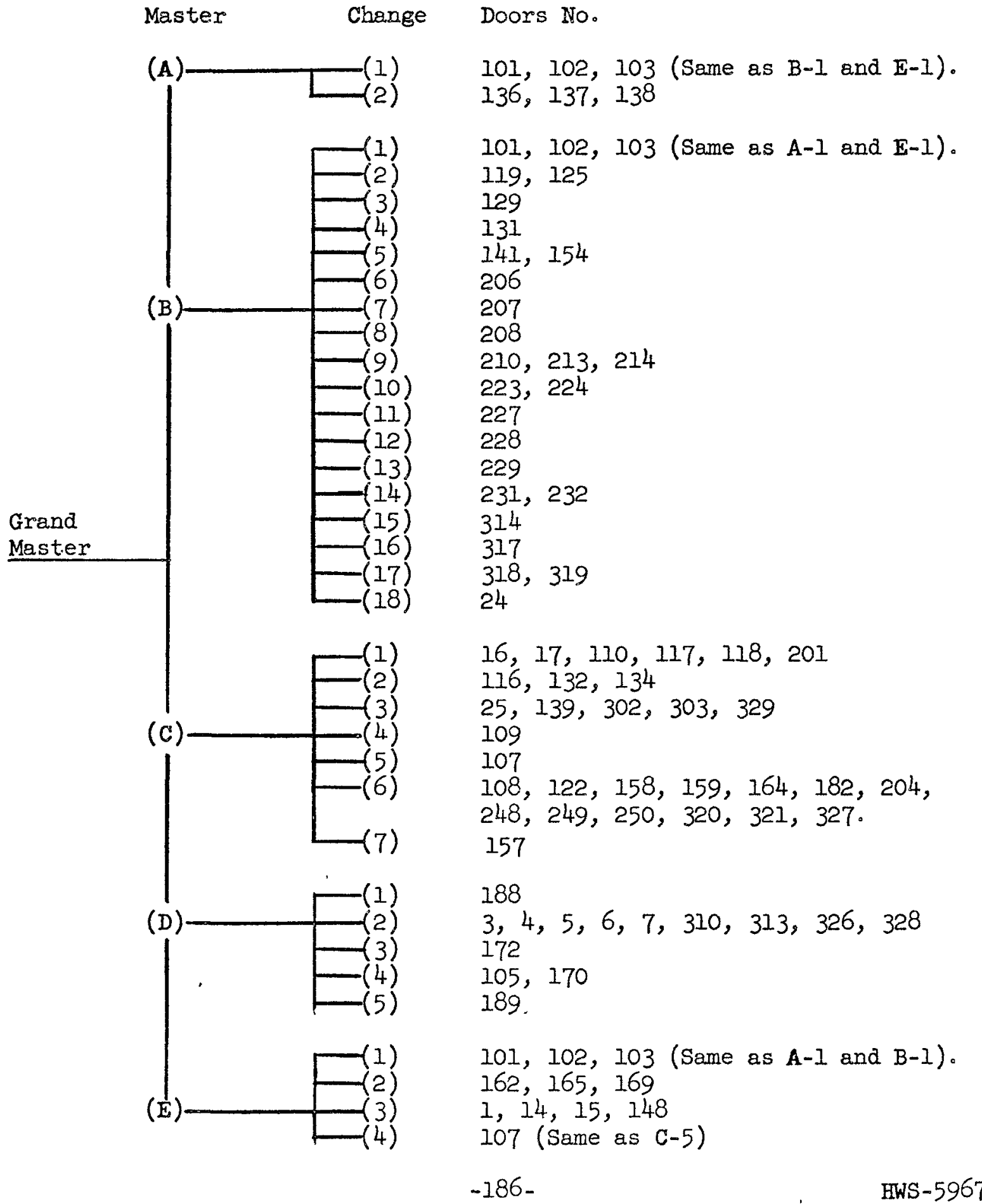


15. IOCK CYLINDERS - Continued

c. In addition, the master key designated as $\mathrm{E}$ above, shall also be the same as existing master key No. $2 E 18927$.

d. Where a particular change key number covers more than one door number, cylinders for these doors shall be keyed alike. Cylinders in different change key groups shall be keyed separately.

e. All cylinders and keys shall be delivered direct from the manufacturer to the following address.

General Electric Company

Security office

c/o L。D. Wright

705 Building

Richland, Washington

\section{WORKMANSHIP}

16. INSTALIA IOION OF HOLIOW METAL DOORS

a. Doors shall be hung plumb and true with proper clearances, and shall operate smoothly and easily without warp or bind.

b. Hardware shall be attached to pedestrian doors with flat head machine screws finished to match the hardware. Hardware on large hollow metal doors shall be attached by bolting or by welding.

c. Doors and hardware shall be installed with care to prevent finger marks, scratches, or other blemishes on doors or hardware.

d. Hardware shall be securely attached, carefully adjusted, and left in perfect working order.

e. Rolled steel channel door frames shall be drilled and tapped for mounting hardware. Hinges on pedestrian doors shall not be welded to door frames.

f. Glass in hollow metal doors shall be held in place by continuous glazing moldings, furnished by the door manufacturer.

g. After completion of the work and inspection by the Cormission, all glass shall be cleaned on both sides and manufacturers labels removed. 
16. INSTALTATION OF HOLLOW METAL DOORS - Continued

h. Number of hinges installed per door shall be as follows:

$$
\begin{aligned}
& 3 \frac{1}{2} " \text { X } 3 \frac{1}{2} "-2 \text { per leaf } \\
& 4 \frac{1}{2} " \times 4 \frac{1}{2} "-3 \text { per leaf } \\
& 5^{\prime \prime} \times 5^{\prime \prime}-4 \text { per leaf }
\end{aligned}
$$

17. INSTALIATION OF ROLL-UP DOORS

Foll-up doors shall be installed in accordance with the manufacturers erection instructions and the approved drawings.

\section{TESTING}

a. Power-operated doors shall be operated through 5 full cycles and travel time checked to assure that the requirements stated herein have been met. limit switches and latching devices on power-operated doors shall be checked for proper operation.

b. Closing devices and automatic door bottoms on swinging pedestrian doors shall be checked for proper operation. 


\title{
DIVISION XII
}

\author{
SPECIAL DOORS AND SHIELDING
}

\section{GENERAL}

1. SCOPE

This division covers the detail design, fabrication, installation and testing of process cell and cubicle shielding doors and cubicle ard duct shillding for the Fuels Recycle Pilot Plant, Building 324. Shislaing doors skall include door frames, gas seals, hinges, door operators, locking devices, controls and accessory piping and/or wiring.

2. SUBMLSSION OF DRAWINGS AND IIVFORMATION

The Contractor shall submit complete dimensioned drawings to the Cormmission prior to fabrication of the doors or cubicle shielding. The drawings shall show the following:

a. Shielaing doors and structural anchorage of hinges and frames.

b. Radiation shielding capacities of individual parts and assemblies

c. Door frame and latching and locking devices.

a. Gas seals.

e. Powsr cperators, with internal power wiring, control wiring and air or hydraulic piping.

f. Auxiliary manual opening and closing devices on the exterior of doors.

g. Any additional mechanisms required for complete and operable units.

The drawings shall be submitted to the Commission for approval prior to the start of fabrication of the doors or cubicle shielding. Firal approve d drawings shall be submitted at the time of shipment of the equipment to the jobsite. Additional information to be furnished at the tims of shipment of the equipment shall include wiring diagrams of power and control circuits, spare parts lists, installation and dismantlement instructions and lubrication instructions. All drawings shall be submitte in accordance with the requirements stated in the Special Conditions. 
3. REFERENCED STANDARDS AND SPECIFICATIONS

The specifications and standards Ilated below form a part of this specification to the extent indicated by subsequent references. Where the listed standards conflict, the Comission reserves the right to specify which shall apply.

3.1 JOINT INDUSIRIAI CONFEREINCE (JIC)

JIC Electrical Standards for Industrial Equipment.

JIC Hydraulic Standards for Industrial Equipment.

3.2 NATIONAL FIRE PROTECTION ASSOCIATION (NEPA)

National Electrical Code - 1959.

3.3 INIERNATIONAL CONFERENCE OF BUILDING OFFICIALS

Uniform Bullding Code - 1961. (UBC).

3.4 U. S. AIR FORCE - MIIITARY SPECIFICATIONS

MII-C-16173A - Corrosion Preventive Compound, Solvent Cutback, Cold Application.

4. DESIGN REQUIREMEINTS FOR SHIEIDING DOORS

4.1 GENERAI

a. The doors shall be located in or on the Hot Metallurgical Celis and Hot Pilot Cells as shown on the construction drawings. Each door and its frame, shall provide nuclear shielding effectiveness equivalent to the door metal thickness indicated on the construction drawings. The closure shall satisfy the pressure and sealing requirements listed below.

b. Each unit (and each leaf of each unit) shall be equipped with a power operator to open and close and to control the movement of the door, with the exception that the cubicle shielding doors, EPN 609 , shall be manually operated. The power operators shall be arranged such that in event of power fallure, the operator can be manualiy operated by crank, handwheel or other means. Clear door openings shall be as shown on the construction drawings.

4.2 LOADS AND SAFETY FACTOR

a. Design loads in addition to the wejght of the materials used shall include: 


\subsection{LOADS AND SAFETY FACTOR (Continued)}

(1) Forces applicable to earthquake zone 2.

(2) Internal cell pressure of 3 psig (except for cubicle doors, EPN 609).

b. All parts subjected to stress shall be designed with a minimum safety factor of five, based on the ultimate strength, or a factor of safety of three based on the yield strength of the materials used.

c. The lifting mechanisms for the crane doors (EPN 602,-604,-607) shall be designed to be capabje of suspending the entire weight of the door.

\subsection{SHIELDING EQUTVALENT}

a. Each door assembly (i.e. the door, its frame and blockout) shall provide nuclear shielding effectiveness equivalent to the iron (Meehanite-density 7.3) thicknesses shown on the drawings for the different door elevations. The size and arrangement of a door frame or hinge blockout can be varied as required to fit the frame, hinge and operator arrangement, provided the effective shielding is not reduced. Acceptable shielding materials are iron (Meehanite), steel, lead, high density concrete, on plain concrete. Cell door surfaces shall be iron or steel. Cell door thicknesses shall not be greater than the thicknesses shown on the drawings, with the exception of the Mechanical Cell door and the upper leaf of a 2-leaf door such as in the Hot Pilot Cells. The upper leaf of a 2-leaf door shall be iron or steel, or shall be a composite of the materials named above, of equivalent radiation shielding capacity to the thickness of iron noted on the drawings. The upper leaf of a door shall not be greater in thickness than the lower leaf of the door.

b. Castings for metal doors shall be ultrasonically tested to determine that such castings do not contain voids or inclusions that would reduce the required total shielding effectiveness by more than one percent. A record of the tests and certification of compliance to these specifications shall be submitted for each casting.

\section{4 PRESSURE AND SEALING}

a. Each cell door shall be provided with an inflatable seal capable of maintaining a leak-tight seal between door and frame against an internal cell pressure of one psig negative to 3 psig positive. At the intersection of cell docrs with crane doors, a wiping seal capable of resisting the ahove cell pressures may be used. The cubicle shielding doors shown on drawing $\mathrm{H}-3-20243$ require no seals. 


\subsection{PRESSURE AND SEALING (Contimed)}

b. Provision shall be made to prevent the by-pass of air behind the seals or seal retainers.

c. Ary wires, conduits, pipes or mechanisms that penetrate the door or cell wall: shali be sealed to meet the pressure requirements stated in Section 4.4 a. above.

\subsection{CEIL DOOR SEALS}

Seals shall withstand continucus temperature of $150 \mathrm{~F}$. , intermittent contact with dilute nitric acid, ard a cumulative radiation dosage of $2.2 \times 10^{6} \mathrm{R}$ (gamma) without failure. Inflatable seals shall be capable of withstanding an inflation pressure of $1-\frac{1}{2}$ times the operating pressurs, but in no case less then $90 \mathrm{psig}$, without rupture. SEals shall provide an unrestrainel movement under inflation of not less than 1./8" greater than the maximim permiscable gap between the door face ara the position of the deflated seal face. Seals shall pull away from the lire of bearing on door or door frame when depressurized prior to cpering the doors. A system shall be provided and instalied which will autematically depressurize the seals prior to door opening. Seal zupfly lines shall be connected such that failure of a seal on an injividual aoor, or door leaf will not result in deflation of the other door Eeal.

\subsection{DOOR HINGES}

a. The hinges of horizontal swinging shielaing doors shall be equipp with bearings to carry the weight of the door plus cther forses $a=$ required in Section 4.2 above. Both the hinges and the door frame or wall support shall te reinforead to prevent displacemext of tis hingss. Hinge pins shall be equipped for grease lubrication of bearirgs ard for ease of removal. Heavy duty bearings shall be utilized to support the radial load and to permit rotation. Precieion tapered roller bearings shall be used to support the deai lcad of the door.

b. The horizontal moment required to open any door shall be less thar 150 ft. Ibs. at a pressure differential of 0 psig.

2. Hing a asembiy adjustment shall be provided to permit miror dcor licetion changes to insure door alignment and clearances after installation.

d. The hinges for Euspended zwing - lift crane doors shall ba equiprs with bearings to carry the weight of the door plus other forees and added safety factor as required in section 4.2 above. 


\subsection{DOOR HINGESS (Continued)}

e. Structural support for the hinge base shall be investigate for orerall capability of supporting the hinge and door loads in the arrsingement proposed without exceeding criteria allowable loads for the walls, ceilings, or floors from which supported.

\subsection{POWER OFERATORS FOR SHIEIDING DOORS}

a. Door cperators are in categories of side-sliding track and trolisy for Hot-Metallurgical ceils (drawirg H-3-20239), single or joubls leaf swirging docrs (drawing $\mathrm{H}-3-20240,-41,-42$ ) and suspecded. siri-g lift crane doors (arawings $\mathrm{H}-3-20240,-41,-42$ ). Electrical ari air driver cperators are show on the drawings. All operators shall be tha same power medium, elestrical preferred.

b. The cperator assembly shall start in a gradual manner, increasing to a relatively rapid speed in the midale cycle of travel, thes grazusily slowing down to the stop position.

c. The operator drive mechanisms for the Hot Pilot Cell doors ana crane doors shall be located in the airlock or on the "Coli" (or operating) side of the celI walls. Drive shafts peretrating tise cell walls shall be sealed by enclosing the operatixg mechanism with an air tight, removable, galvanized sheet metal box.

d. The operator drive mechanisms for the Hot Metallurgical Cell acors shall be located on the door trolleys and shall be fluid courifirg type.

e. Crase door lift mecharisms shall be designed with $100 \%$ adel safety factor for all lifting devices incluaing sheaves, cables, st.s. to insure against ureortrolled lowering of the door leat. Deaign shail include positive supporit lugs that will engage the door leaf in sx "up" position thereby ralieving the load from the lifting mesharism during erane operation in and out of the cells.

f. The maximum relooity of the peripheral edge of a suinging door or the edge of a side moving door skall be less than $1 / 2$ ficot $F \leqslant r$ Eeconi.

8. Excessive impact shall not occur as the door operator reaches the oper or closed position.

h. The cpewatcr shall have a capacity to perform normal door operitic= at 50 pereant of its ratea capacity. 


\subsection{POWER OPERATORS FOR SHIELDING DOORS (Continued)}

i. Ary gears shall be cut gears. Shafts and gears shall be mounted with long-life kearings enclosed in an oil tight enclosure.

\subsection{LOGKS AND CONIROIS}

a. Esch door shall be equipped with locking devices that car oriy be unlocked by a remote electrical release control switch. Provision shall be made to open each door manually from the exterior sids.

b. Motor control shall be through magnetic reversing starters iccated in the motor control centers. Control circuits shall be 120 volts 60 eycle, single-phase. Each door control circuit shall be elestrically separate from other door circuits. Wiring shall comply with J.I.C. Electrical Standards For Industriel Equipment an 2 mirimum wire size shall be \#12. Ecclosures shall be NEMA Type 12 or NEMA Type 4 external to cells or airlosks, and NEMA Type 4 intemai to cells and airlocks. All wire insulation shall be polyethylene.

c. Limit switches shall be provided to stop door operators at extremes of travel and to control light signals. Control switches shail be provided in accordance with drawings $\mathrm{H}-3-20335$ and $\mathrm{H}-3-20338$. Where there are two control stations for the same door, only one shali be operative at one time. The first station unlocked shall estaklish and maintain priority. If both stations are unlocked neither station shall be operative. The cortrol circuits shall provide a sequenze of cperation ard interiooks such that:

(I) For door opening, the inflatable seals deflate, and the losining dogs retract.

(2) For door closing, the door must be fully closed and losked before the inflatable seals can be inflated.

(3) Fcr doors of more than one leaf, interlocks shall be provided to sequence the opening of the bottom door first.

(4) Crane door controls shall be arranged so that the dcora car be opened without opening the cell doors.

d. Pressure switches, marked "Vent-Door Limit Controls" on drawing H-3-20335 shall be installed to make contact and actuate cell ventilation damper controls wher inflatable door seals are deflated. Pressure switches shall op Erate a 3-way solenoid valve which ir tura shall control the damper operator. Pressure switches shall be rated at not less than 5 amps, at 110 volts, 60 cycle A-C. Eismertary diagrams showing connections appear on drawing H-3-20385. 


\subsection{LUURICANTS, GASKETS AND SEAIS}

a. Door hinges, operators and mechanisms shall be so constructed or housel as to prevent the dropping of oil, grease or hydraulic fluid on floors, walls or doors.

b. All lubricants and hydraulic fluids, and the gaskets and seals used to contain same, shall resist not less than $1 \times 10^{8}$ roentgens of gamma radiation, under moderate temperature conditions, without deterioration. The Contractor shall submit to the Commission certification that the materials used for lubricants, hydraulic fluid, gaskets, and oil and grease seals have been tested and determined to comply with this radiation resistance requirement.

c. Lubricants and hydraulic fluids shall be compatible with gasket and seal materials used to contain them.

\section{SERVICES}

The following services are available for operation of the doors:

a. Compressed air at 90 psig. maximum and 80 psig. minimum.

b. Electrical power at 440 volt, three-phase, 60-cycle.

\section{CUBICLE AND MISCELIANEOUS SHIEIDINE}

Dimensions of cubicle shielding and miscellaneous shielding around ducts adjacent to process cells are based on a density equivalent to Meehanite (density 7.3). The shielding used shall have equivalent strength, machinability and shielding effectiveness. Where lead is specified for shielding, such as around Transfer Mechanism housings, lead shall be installed.

\section{SURFACE FINISHES}

a. The rinish for surfaces of shielding doors and cubicle shielding, which are not to be embedajed in concrete, shall be equivalent to that of sand-blasted steel plate. Surface pits and gouges greazer than $1 / 16$ inch in depth or diameter shall be repaired prior to application of special prorective coatings.

b. Finish coating is specified on drawings $\mathrm{H}-3-20174$ and $\mathrm{H}-3-20175$, except that machined surfaces such as bearing surfaces and sealing surfaces shall be coated, prior to shipment from the fabrication shop, with a corrosion preventive compound conforming to MIL-C16173A, Grade I, or approved equal. Grease shall not be used for this purpose.

c. All mold marks, fused-on sand, and sharp projections shall be ground flush prior to coating. Surface sponginess shall be removed. Voids and surface pits shall be filled with weld metal 
c. (Continued)

of a density greater than that of the casting or plate. Corners and edges of shielding shall be free of flaws or cracks due to casting defects or handling of parts.

d. All ferrous surfaces of doors and shielding which are to receive special protective coatings, shall be completely degreased, in the manufacturer's plant prior to any coating work or prior to shipment to the jobsite.

e. The surfaces of a door against which inflatable seals are to seal shall lie in one plane. Surfaces other than sealing surfaces may vary gradually (not to be confused with "pits, dents, etc.") from a plane, but only such that at no point will it be possible to pass a $1 / 8^{\prime \prime} \times 1$ " probe under any part of a 10 foot straight edge held against a door face.

\section{TESTING}

a. The Contractor shall furnish all the necessary facilities for testing the doors. He shall be responsible for conducting the tests to demonstrate, to the satisfaction of the Commission, that the requirements of this specification and the referenced standards and codes have been met. Each completed and installed door assembly shall be successively cycled ten times without failure.

b. Seal tightness shall be established by probe tests. Passage of a $0.002 " \times 1 / 2 "$ probe between an inflated seal and the surface to which it is to seal, anywhere on its length, will be evidence of the unacceptability of the seal. Wiping seals at the crane rails and between the crane doors and the cell doors shall be subject to the same test. 


\section{DIVISION XIII}

\section{SPRINKIER SYSTEM}

\section{GENERAL}

\section{1. - SCOPE}

This division covers the design, fabrication, installation and testing of a wet pipe, automatic sprinkler system, within the limits shown on Drawinz H-3-20428, for the Fuels Recycle Pilot Plant, Building 324.

\section{SUBMISSION OF DRAWINGS AND INFORMAIION}

a. The Contractor shall furnish complete, detailed installation drawings, wiring diagrams, equipment drawings, specifications and operating and maintenance instructions for approval, for all equipment to be furnished by the Contractor under this division of the specifications. Approval of the above drawings, diagrams, specifications, and instructions shall in no way relieve the Contractor of responsibility for a complete job. Approval will be for design and general arrangement only and not for dimension or quantity.

b. Approval by the Washington Surveying and Rating Bureau is required before equipment is installed. Drawings and information shall be submitted in conformance to the requirements stated in the Special Conditions.

\section{REFERENCED CODES AND STANDARDS}

The codes and standards listed below form a part of this specification

to the extent indicated by subsequent referemces.

3.I NATIONAL FIRE PROTECTION ASSOCIAIION (NFPA)

NFPA No. 13 - Installation of Sprinkler Systems, 1961 Edition

3.2 INTERNATIONAL CONFERENCE OF BUILDING OFFICIAES

Uniform Building Code (UBC), 1961 Edition

4. DESICN REQUIREMENTS

a. The sprinkler system shall be designed for ordinary hazard occupancy as required by the NFPA 13. 


\section{DESIGN REQUIREMENTS - Continued}

b. The sprinkler system design shall be approved by the Washington Surveying and Rating Bureau prior to submission for Commission approval.

c. The system shall include the following features:

(1) The alarm valve shall be installed with an automatic excess pressure pump, Gamewell Company, "Gamewell Sprinkler Watchman", or approved equal.

(2) A retarding chamber shall be provided, with suitable valves, to permit repair or removal without shutting off sprinklers.

(3) The system shall be equipped with a siamese exterior fire department connection with check valve and automatic drain, a water motor exterior alarm, low water pressure supervisory panel and alarm and the standard piping and alarm trim. The low water pressure alarm contacts shall be double pole, double throw. A manual valve shall not be included between the outside post indicator valve and the alarm valve.

(4) Inspectors' test valve stations shall be provided at the terminal end of supply mains.

(5) All piping in the sprinkler system shall be braced for earthquake resistance as required for Earthquake Zone 2 as defined by the UBC.

d. The system and component parts of the system shall be the standard products of manufacturers equipped and experienced in the manufacturing of wet pipe sprinkler systems. The design and installation of this system shall be in accordance with these specifications and NFPA-13.

e. Sprinkler piping shall not be iocated in the space required for installation and removal of manipulators from cell walls. This is a projected space 18 inches wide from 21 inches above the centerline of the manipulator to the floor for a distance of 14 feet from the outside face of the cell wall.

\section{MATERIALS}

\section{MATERIALS AND EQUIPMENT}

\subsection{GENERAL}

a. All materials and equipment shall be approved by the Underwriters 


\section{MATERIALS AND EQUIPMENT - Continued}

\subsection{GENERAL}

\section{a. (Cont.)}

Laboratories, Inc., or by nationally recognized testing laboratories approved by the NBFU, or by the Commission.

b. All material shall comply with NFPA 13 .

\subsection{PIPE AND FITTINGS}

a. All pipe shall be standard weight, black steel pipe.

b. Pipe fittings shall be cast iron screwed fittings especially designed for sprinkler work and suitable for $175 \mathrm{lb}$. working pressure. Reducing fittings shall be used where changes in pipe sizes occur. Bushings are not acceptable.

c. Pipe hangers and supports shall be of the types shown on the drawings .

\subsection{SPRINKIER HEADS}

a. Sprinkler heads shall be Grinnell "Duraspeed", or approved equal.

b. Sprinkler heads for all locations except adjacent to unit heater in the truck lock shall be $165 \mathrm{~F}$ rating. Heads in the truck lock shall be $180 \mathrm{~F}$ rating.

c. Spare heads, wrenches, etc., shall be furnished in lots recommended by NFPA.

\subsection{AUTOMATIC DEVICES}

a. All sprinkler specialty materials such as alarm valves, post indicator valves, check valves, etc., shall be standard products of the sprinkler equipment manufacturer.

b. Alarm valve and retard chamber shall be connected with three position valve in lieu of two stop cocks for inspector's test.

\subsection{PUMPER CONNECTION}

a. Siamese pumper connection shall have a 4-inch female end and two, $2 \frac{1}{2}$-inch male ends with caps and chains.

\subsection{FLOW SWITCHES}

Flow switches, to be located in supply mains to each Zone shall have contacts rated at 5 amperes, 115 volts, 60 cycle AC. 


\section{MATERTAIS AND EQUIPMENT - Continued}

\subsection{PUMPER CONNECTION}

b. Connection shall have National standard fire threads.

\section{WORKMANSHIP}

\section{INSTALIATION OF SYSTEM}

a. Installation of system shall conform to NFPA 13.

b. Piping shall be run parallel to walls and arranged to pitch down to drain at main valves. Drains shall be run to outside or to builjing arains.

c. All piping shall be reamed free from all burrs and to the nominal size of the pipe.

d. All piping shall be cleaned of all foreign matter before assembly. Ends of piping systems shall be kept capped when erection is not in progress. Lines shall be thoroughiy flushed after erection.

e. All screwed joints in steel pipe shall be made with approved thread lubricant applied to the male threads only.

f. All runs of 21 feet or less shall be in one length of pipe. Runs over 21 feet shall be made with a minimum number of joints, using full lengths of pipe insofar as possible.

g. Nipples with unthreaded section l-inch or less in length shall be cut from extra heavy pipe.

h. Cross mains shall be supported independently of branch lines. In no case shall branch hangers assume any portion of the weight of the mains.

i. All sprinkler system piping shall be disinfected by the same means as specified for sanitary water piping in Division VI. All rubber valve seats shall be removed prior to disinfecting sprinkler system piping and replaced after lines have been flushed.

\section{FUNCTIONAL DIAGRAMS AND IDENTIFICATION}

Large scale functional diagrams, showing alarm valve components and part numbers shall be framed under glass and mounted near the alarm valve. Permanent identifying signs and legends shall be provided to identify, 


\section{FUNCTIONAL DIAGRAMS AND IDENTIFICATION - Continued}

warn or instruct in the function and operation of features such as inand drains, etc.

8. TESTS AND FINAL ACCEPTANCE

a. The tests listed in NFPA 13 shall be performed.

b. The Contractor shall obtain and deliver to the Commission a certificate stating that the systems as installed have been inspected and accepted by the Washington Surveying and Rating Bureau.

c. All sprinkler system piping shall be flushed with water after erection for a period of 30 minutes. Flushing water shall be supplied at a pressure sufficient to provide a flow velocity of $10 \mathrm{fps}$ in all branches of the section of the system being flushed. 


\title{
DIVISION XIV
}

\section{CRANES ATD HOISTS}

\author{
GETERAL
}

\section{SCOPE}

This divisior covers the design, fabrication, erection and testing of elestric motor driven cranes and hoists for the Fuels Recycle Pilot Flant, Builaing 324.

2. SUBWIDSION OF DRAWINGS AND IINORNATION

a. The Contractor shall submit copies of the following to the Ccmmission for comment and approval prior to fabrication of the cranes:

(I) Dimensioned shop drawings of all cranes and hoists.

(2) Wiring Diagrams ireluding control and safety circuits.

(3) Specifications for materials.

(4) Hoisting and travel speeds and gear reduction data.

b. Final copies of the information outlined in paragraph (a.) above together with lubrication, maintenance and operating instructions shall be submitted to the Conmission at the time of shipment of the equipment to the jobsite.

c. Drawirgs and information shall be submitted in accordance with the requirements stated in the Special Conditions.

3. RHTERENCED STANDARDS AND SPECIFICATIONS

The specifications and stardards listed below form a part of this specification to the extent indicated by subsequent references.

3.1 AMERICAN STANDARDS ASSOCTATION (ASA)

ASA B55.1-w1950, Gray Finishes for Industrial Apparatus and Equipment

3.2 FEDERAL STANDARDS

No. 595-1956 Colors 


\title{
3.3 ELECTRIC OVERHEAD CRANE INSTITUTE (EOCI)
}

\author{
E.O.C.I. No. 61 - Electric Overhead Traveling Cranes
}

3.4 HOIST MANUFACTURERS ASSOCIATION

Specifications for Electric Powered Wire Rope Hoists

3.5 MONORAIL MANUFACTURER'S ASSOCIATION (MMA)

Specifications for Overhead Track Systems, 1955

3.6 NATIONAL FIRE PROTECTION ASSOCIATION (NFPA)

NFPA 70-1959, National Electrical Code (NEC)

\subsection{HANFORD STANDARDS}

D-20-10, Rev. 0, System and Equipment Grounding - Basic Requirements and Conductors

4. DESIGN REQUIREMENTS

4.1 GENERAL

a. Motor driven cranes described below shall be furnished complete, in place, tested, and operable. The cranes shall conform to the requirements of the referenced standards unless specified otherwise herein. The cranes are classified as either Under-Hung or Top-Running and In-Cell or Out-of-Cell.

b. Underhung cranes shall conform with the MA standards and this specification.

c. All cranes shall be capable of handling a load of $125 \%$ rated capacity.

d. Top-Running cranes shall conform to EOCI standards for Class B (Light Service).

e. General crane characteristics are shown in Table I herein. Identification of cranes shall be by equipment piece number, e.g. EPN-324-700. The rated lifting capacity for each crane shall be as shown in Table $I$.

f. Travel and hoist speeds shall be as shown in Table I.

g. All hoists shall be equipped with two independent braking means:

(1) An automatic mechanical load brake which will automatically control the load during lowering to prevent undue acceleration. Load brake shall be rated at 125\% of hoist capacity. 


\section{BUILDING CRANES AND HOISTS}

TABLE I

\begin{tabular}{|c|c|c|c|c|c|c|c|c|c|c|}
\hline \multirow{8}{*}{$\begin{array}{l}\text { 曷 } \\
\text { 息 } \\
\text { 台 }\end{array}$} & \multirow{2}{*}{$\begin{array}{l}\text { EPN } \\
324 \\
\end{array}$} & \multirow[b]{2}{*}{ LOCATION } & \multicolumn{4}{|c|}{ CAPACITY SPEED - FEET PER MIN。 } & \multirow{2}{*}{$\begin{array}{l}\text { ARRANGEMENT } \\
\text { DRAWING }\end{array}$} & \multirow{2}{*}{$\begin{array}{l}\text { BRIDGE } \\
\text { TRUCKS } \\
\end{array}$} & \multirow{2}{*}{$\begin{array}{c}\text { MOTOR } \\
\text { COUPLING }\end{array}$} & \multirow{2}{*}{$\begin{array}{l}\text { RUNWAY COND } \\
\text { LOCATION }\end{array}$} \\
\hline & & & TONS & LIFT & TROLLEY & BRIDGE & & & & \\
\hline & -700 & $\begin{array}{l}\text { HP Cells } \\
\text { Airlock }\end{array}$ & $5 \mathrm{~T}$ & $0-20$ & $0-20$ & $0-20$ & $\mathrm{H}-3-20235$ & Top Running & Direct & Cable Reel \\
\hline & -701 & $\begin{array}{l}\text { HP Cells } \\
\text { Pyro }\end{array}$ & $2 \mathrm{~T}$ & $0-20$ & $0-20$ & $0-20$ & $\mathrm{H}-3-20235$ & Under Hung & Direct & Cable Reel \\
\hline & -702 & $\begin{array}{l}\text { HP Cells } \\
\text { Low Bay }\end{array}$ & $6 T$ & $0-20$ & $0-20$ & $0-20$ & $\mathrm{H}-3-20235$ & Top Running & Direct & Cable Reel \\
\hline & -703 & $\begin{array}{l}\text { Met. Cells } \\
\text { Airlock }\end{array}$ & $5 \mathrm{~T}$ & 5 & 10 & 10 & $\mathrm{H}-3-20236$ & Top Running & Fluid & Cable Reel \\
\hline & -704 & $\begin{array}{l}\text { Met. Cells } \\
\text { Prep. }\end{array}$ & $3 T$ & 5 & 10 & 10 & $\mathrm{H}-3-20236$ & Under Hung & Fluid & Cable Reel \\
\hline & -705 & $\begin{array}{l}\text { Met.Cells } \\
\text { Fabr. }\end{array}$ & $3 T$ & 5 & 10 & 10 & $H=3-20236$ & Under Hung & Fluid & Cable Reel \\
\hline \multirow{6}{*}{ 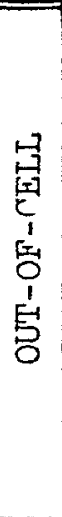 } & -706 & $\begin{array}{l}\text { Cask } \\
\text { Handling }\end{array}$ & $\begin{array}{c}30 T \\
5 T \text { AUX }\end{array}$ & $\begin{array}{l}0-20 \\
0-46\end{array}$ & $0-30$ & $0-65$ & $\mathrm{H}-3-20234$ & Top Running & Direct & East Side \\
\hline & -707 & $\begin{array}{l}\text { Low Level } \\
\text { Canyon }\end{array}$ & $5 T$ & 20 & 65 & 90 & $\mathrm{H}-3-20237$ & Under Hung & Fluid & North Side \\
\hline & -708 & $\begin{array}{l}\text { Regulated } \\
\text { Shop }\end{array}$ & $5 \mathrm{~T}$ & 20 & 65 & 90 & $\mathrm{H}-3-20237$ & Under Hung & Fluid & South Side \\
\hline & -709 & $\begin{array}{l}\text { Cold } \\
\text { Shop }\end{array}$ & $5 T$ & 20 & 65 & 90 & $\mathrm{H}-3-20237$ & Under Hung & Fluid & South Side \\
\hline & -710 & $\begin{array}{l}\text { Cold } \\
\text { Canyon }\end{array}$ & $5 \mathrm{~T}$ & 20 & 65 & 90 & $\mathrm{H}-3-20237$ & Under Hung & Fluid & East Side \\
\hline & -712 & $\begin{array}{l}\text { Vent \& } \\
\text { Equip. Room }\end{array}$ & $\overline{2 T}$ & 35 & 65 & -- & $\mathrm{H}-3-2022 \mathrm{I}$ & Under Hung & Direct & Either Side \\
\hline
\end{tabular}


4.1 GENERAL (Continued)

(2) A solenoid-operated hoist motor brake interlocked with the motor control to quickly stop the hoist drum when power to the motor is interrupted. The torque rating of the hoist brake shall be not less than $125 \%$ of that of the hoist motor.

\subsection{IN-CELL CRANES}

a. In-Cell cranes will be subject to high nuclear radiation and an occasional water deluge. The In-Cell cranes will be located in the Hot Pilot Cells and the Hot Metallurgical Cells.

b. Mechanical requirements for In-Cell cranes are as follows:

(1) The In-Cell cranes shall be designed for the minimum hookto-wall distance, maximum hook lift, and crane clearances shown on the arrangement drawings $\mathrm{H}-3-20235$ and $\mathrm{H}-3-20236$.

(2) The overall length of bridge end-trucks shall be kept to a minimum, but wheel base lengths shall not be less than required by the ratio stated in EOCI 61 .

(3) A sheave-shuttle type trolley and hoist system with fixedposition power units is the basis on which the crane hook. clearance limits have been determined. This does not exclude other systems meeting the requirements of this specification and conforming to the hook clearances shown on the drawings.

(4) Anti-friction bearings shall be used for all journals. All gearing shall be enclosed and lubricated with grease. Cranes shall be constructed so as to prevent the dropping of oil, grease or hydraulic fluid on the crane or below.

(5) Lubricants and hydraulic fluids, and the gaskets and seals that contain them shall be chemically compatible and shall not deteriorate on exposure to less than $1 \times 10^{8}$ gamma radiation. Lubricants, hydraulic fluid, gaskets and seals shall be certified to the Commission as meeting these requirements.

(6) Crane arives for the Hot. Metallurgical Cell cranes shall be single speed with a fluid coupling. The hydraulic oil used shall not deteriorate under less than $1 \times 10^{9}$ roentgens of gamma radiation.

(7) All gaskets and oil seals shall be polyethylene.

(8) The bridge and trolley drives shall have solenoid brakes rated at not less than $50 \%$ of the full load motor torque.

(9) On drives utilizing fluid couplings, the solenoid brakes shall be applied on the load side of the coupling. 


\subsection{IN-CEIL CRANES (Continued)}

(10) The bridges of cranes EPN 702, 704, 705 shall be proridis with a hook interlccked with a bridge brake release mestanism that will permit, in the event of loss of bridge power, the withdrawal of the crane from the cell into the airlock by means of a cable. Crane EPN 700 shall be similarly equipped except hooks shall be provided on each slde for crane withdrawl from either the Hi-Bay or Mecharicgi Cell. Hook locations on the crane bridges shall be $2^{\prime}$ to $3^{\prime}$ from the crane rail on the side of the bridge fasing the crane door or closure.

(11) Rails for underhung cranes shall be supported from the $: \leq 11$ ceilings. The bolts used to support the rails shall be embedded in the concrete and may be welded to the reinforsirg steel. In the Pyro-Cell, the anchor bolts shall be atairi $=\equiv$ steel and shall be flarged and seal welded to the stricis:z steel cell liner. (See detail drawing H-3-20273).

(12) The crane bridges shall have one or more bolted concection: to permit a crane to be dismantled and removed from the celi without welding or cutting any stmetural members.

c. Wiring and controls for the Irocell cranes shall be in accoriarie with drawings $\mathrm{H}-3-20338, \mathrm{H}-3-20352$, the NEC and Hanford Stardard. D-20-10. All wire and cable within the cells shall be irsulstei and jacketed with polyethylene. All electrical enclosures sinall be NEMA Type 4 within the cells and Type 4 or 12 exterral to thy cells. Cable connector shall be watertight. Limit swit:be shall be provided to limit travel ir both direstions of the kri $3 g e$, trolley and hoist. A second (or back-up) limit switch shall be provided for the hoist "up" motion. A limit switch shall te prea vided to prevent hoisting loads exceeding 125 per cent of rare $\dot{z}$ crane capacity. Size of conduits and boxes, number of wirss axa connections shall be determined by the fabricator of the equir. ment. The block diagram on drawing H-3-20352 showe the zuggest $\equiv 2$ routing of wire raceways.

d. Specific electrical requirements for the Hot Metallurgi:al Ceil cranes are as follows:

(I) All crane motors shall be 440 volt, three-phase, sixty cycle with totally enclosed frames and Class B or $\mathrm{H}$ insulation rated for 30 minutes. Power ard control circuits to the crane shall be via a spring driven take up resl. The cable reel shall be positioned on the crane bridge so that it can never pass closer than 6 feet to the junction box 


\subsection{IN-CELI CRANES (Continued)}

a. (Continued)

embedded in the ceiling. (See drawing H-3-20299).

(2) Each movement of the crane shall be controlled from portable control stations connected to the wiring system through cable plugs and receptacles. There shall be one portable control station for each of the three cranes. The plugs ard. receptacles shall be interchangable. Three receptacles sinaij be provided for the Preparation Cell Crane, one receptacle for the Air-Lock Cell Crane, and seven receptacles for the Fabrication Cell Crane. Electrical brakes shall be appliea as in paragraphs (7) and (8), section $4.2 b$, this specification.

e. Specific electrical requirements for the Hot Pilot Cell cranss are as follows:

(I) All crane motors shall be shunt or compound wound, direst current with totally enclosed frames and Class B or H insulation rated for 30 minutes. Power and control circuits to each crane shall be via a spring driven take-up cable reel mounted external to the cells. Cable duct and sheaves shell be located to produce a minimum of wear on the cable. The ducts through the cell walls shall have nylon bushirgs borez to a sliding fit on the cable, rounded and smoothed. The cable supplying power to the Low Bay Crane shall be rur. through the wall duct and the crane door (between Iow Bay and Airlock) and aligned to cause minimum cable wear and interference in the Airlock. The crane door shall be grooves and bushed for this cable and intermediate surport 5 provids along the south wall of the Airlock.

(2) The Low Bay Cell Crane and Airlock Cell Crane movemente shail be controlled from a station in the control room. The Pyro Cell crane shall be controlled from a portable station loset $E$ इ in the operating gallery.

(3) Speed variation in all directions shall have five steps sach. Crane motors shall be equipped with series-connected brakes and maximum safe speed limits. Power supplied for rectification to direct current shall be at 440 volts, three-phas $\triangleq$, sixty cycles. Direct currert power supply and control cabinets shall be of NEMA Type 1 corstruction with dust gasists. The cabinets shall be free-standing, floor-mounted units. 


\subsection{OUT-OF-CELU BRIDGE CRANES (Continued)}

b. (Continued)

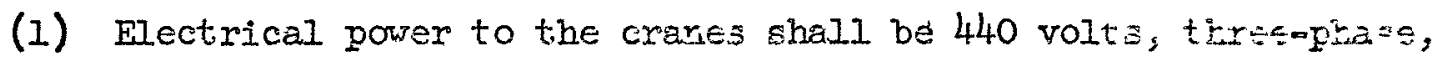
sixty cycles. Building plans show the wiring from the control center to the crane disconnect switch. All rarirg b-yond the disconreat stitch ehall corform with NEC sta Harfcri Standard D-20-10. Enclosures shall be NEMA Type 12 or waiser. proof.

(2) Iimit switches shall be provided to limit travel of briage, trolley and hoist. A steond $(c x$ back-up)limit switch sivil be provided for the "UI" motion of the hoist. A load limit switch shall be provided and adjusted to $125 \%$ of rated eapacity.

(3) Motors on under-bung cranes shall be 440 volt, throsupha = sixty cycles, single-spee, suitable for crane ard hoz $5+5 \leqslant r-$ vice; with totally ercloefd frames. Motors shall ba razej for 30 minutea, $75^{\circ} \mathrm{C}$ rise. Motor control for each underhung crane motion shall be mechanically and electriziliy interlocked.

(4) The Cask Handling Crane motors shall be shunt or compois

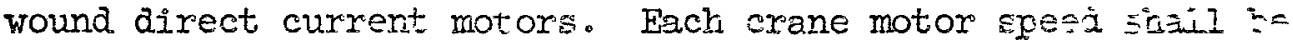
variable by a motor generator set supplying adjustatle Tolrej= DC power. The motors shall be short-time rated, 30 minu- $=$, for a temperature rize of $75^{\circ} \mathrm{C}$ and with totally $\in \mathrm{c}=10 \leqslant \pm 2$ frames. The movor generator sets and accessories silil ks mounted on the crare in a INEMA Type 1 gasketei enclosure.

(5) Control of each erane shall be from a pendant atation s-a pended from the trolley (cee drawangs $\mathrm{H}-3-20234$ ar $\bar{x} \mathrm{H}-3-$ 20237). A selectcr writcr chall be included in the ponzis: controller to control the crane flood lights. All pishini.tons and selector switches shall have nameplates to idstify their functions. Each pendant controller shall have a 512 gle hand grip that does not interfere with operation of the pus buttons. Each penciant control exclosure, if mads of $m=+3$, shall be grounded through a eparate condustor within twsuspending cable. Also see drawngs $\mathrm{H}-3-20338$ and $\mathrm{H}-3-20352$.

(a) A separate pushbutton wall be provided for $\leqslant a-b$ mot $10=$ of the undishurg cranss. All control circuits shill $\mathrm{k}=$ 110 volts. 
Missing Page
from

Original Document 


\subsection{OUT-OF-CELL BRIDGE CRANES (Cortinuẽ̃)}

5. (Continued)

(b) The Cask Handling Crane perdant station shall bave a rotatins selector switch with five speed positions in both jurections and an "Off" position is the center for each crane motor. The switch shall have a rajial lever type handle and ie epring return to "Off" position. Contrcl circuits shall not excesi 125 volts ard shall be grounded at one pole or neuizral.

6. Flood lights shall be provided to illuminate the flcor diractly below the erane to 20 foot candies irtemsity. The lights shail by

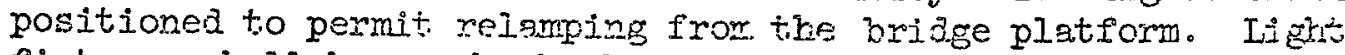
fixtures shall kave shock-aksorbing mountings or scckets.

7. All rumway and briage contact conductors shall be enclosed or insiated except for a slot by means of which the collector contact shoe may engage in sliding contact with the aonductor. The coliector shall be so insulated that it may be withdraw from contact with tis conductor by hand without dariger of accildental contant with electrically energized parts. The collectom shall be constructea $\div 0$ allow removal from the scriustor at any point in the ris. "Incu8-bar" manufactured by Insul-8-Corporation wili mest these spesifications. The briage contact conductors will preferrakly be located along the inner web of the bridgye girders, but tie conductors shall not be located or tho girdier adjacent to the baidge drive or platform. The crene bridge anji trolley shall be grourea in accordance with Hanford Standard D-2O)-10 utilizing a separate crane contact conductor for the equipmemt ground. The ruxiray contact conductors shall be supponted frcom the building structurai steel adjacent to the side of the ruxway specified in Table $I$.

4.4 OUT-OF-CELL MONORAIL HOIST, EPN 324-7I2

a. The monorail hoist EPN-324-712 shall be rated at 2 Ton eapacity arz shall conform to the standard specificattion of the Hoist Marufesturer's Association. The hoist shall bre mounted on a motorized trolley suitable to man on a lOWF2l crauns beam. The crane rail is shown on H-3-20221, detail 280 and 281. Find stops shali bo providez on the crane rail. The total hook lift shall be forty fest. The maximum distance from bottom of the crarre rail to the hosis when fully lifted shall be 30 inchea.

b. Monorail hoist and trolley motors shall be 440 volts, thres priess; sixty cycles. Frul voltage reversing motcr starters in NEMA Iyp: 1 enclosures shall be mounted on the trolley. 


\subsection{OUT-OF-CELL MONORAIL HOIST EPN 324-712 (Continued)}

c. The hoist and trolley shall be controlled from a pendant controlis: suspended from the trolley. Sufficisnt cable shall be provinej \pm permit the trolley to be at the extreme eastern position wifie ris: cortroller is within the building. Cable clamps or hooks shail $=$ proviled to permit coiling and fastening the cable so the contrciler is five feet above the floor.

d. A $\longrightarrow$ limit switch shall be provided on the hoist urit to limis the lift and lower extremes. The hoist shall have a solenoid opsated lowering brake.

e. Power shall $k \in$ supplied to the trolley through a spring takewr aable reel or through insulatex runway conductors. A fiftsen. ampere fused disconnect, for this service is shown on dratirg $\mathrm{H}=\mathrm{j}=$ 20343 and is located ir Motor Coritrol Center 1 . The sls strical plan is shown on drawing $\mathrm{H}-3-20305$.

\section{PAINTING}

\section{I GENERAL}

a. All cranes and hoists shall have the trolleys, lower sheave kIcisz and lifting hooks fixished ir "focal orange", color No. 12z's psr Federal standard 595.

b. The crane brijges, trucks, rails ard other parts not msrition: it paragraph a. above shall be firished in medium light gray, No. Lo per ASA z55.1.

c. Sliding or rolling contact surfaces shall rot be painted.

\subsection{IN CELL CRANES}

All six In-Cell cranes shall be coated with chemical resistant raint, system No. I (CRP-I) as identifiza ir Division XVI. Preparation cf surfaces and application of the coating shall be the same $a \geqslant$ for or $r=5$ metal items receivirg this coating system.

\subsection{OUT-OF-CELL CRANES AID HOISTS}

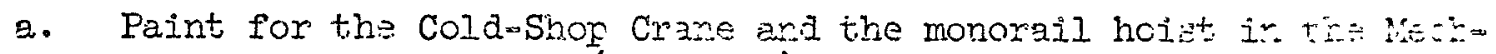
anical Equipment Room (Room 317) shall be furmished in tre tion

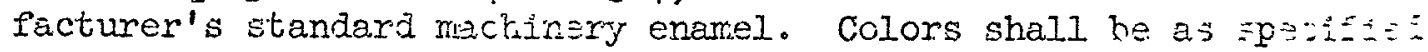
in Section 5.1 above. 


\subsection{OUT-OF-CELI CRANES AND HOISTS (Continued)}

b. Cranes in the Cold Canyon, Low Level Canyon, Regulated Shop and in the Cask Handling Area shall be coated with chemical resistant paint No. 2 (CRP-II) as specified in Division XVI.

6. TESTING

Each crane shall be tested after complete installation to demonstrate the crane meets the following requirements:

a. When crane is loaded to full rated capacity, the maximum speeds for hoist, trolley travel, and bridge travel will meet the specification. Adjustable speed cranes shall have the speed steps in approximately equal increments.

b. The crane shall lift, without damage to the crane or rails, a load equal to 125 per cent of rated capacity.

c. The load limit switch shall be adjusted to prevent hoisting of load in excess of 125 per cent rated capacity.

d. The illumination of the crane flood lights shall be verified to be a minimum of 20 foot candles on the floor below in the absence of all natural or other artificial light.

e. The operation of all limit switches shall be verified.

f. The hook-to-wall minimum distances, maximum hook height, and clearances shall be verified as complying with the specifications. 
DIVISION XV

BLEVATOR AIND DURBWAITER

\section{GENERAI}

\section{1. $\mathrm{SCOPE}$}

This division covers the elevator and dumbwatter and accessory controls for the Fuels Recycle Pilot Plant, Building 324.

2. REFEREANCED STANDARDS AND SPECIFICATIONS

The standards and specifications listed below form a part of the specification to the extent indicated by subsequent references.

2.1 AMERICAN STANDARDS ASSOCIATION (ASA)

ASA A17.1 - 1960 Safety Code for Elevators, Dumbwaiters and Escalators.

2.2 AMERICAN SOCIETY FOR TESTING AND MATERIAIS (ASTM)

ASTM A36-6IT Specifications for Structural Steel.

2.3 NATIONAI FIRE PROTECTION ASSOCIATION (NFPA).

NFPA $70-1962$ National Electrical Code (NEC).

3. SUBMISSION OF DRAWINGS

The Contractor shall furnish to the Comission for approvel, detalled installation drawings, wiring diagrams, equipment drawings and specifications covering all equipment to be instailed in accordance with the requirements of this division. The drawings shall show how the equipment is to be adapted to the space provided. in the building structure as well as details of

$i$ items to be embedded in concrete or masonry. Drawings shall. be delivered to the Commission 30 days prior to purchase of equipment. Submittal of drewings shall be in accordance with the requirements stated in the Special Conditions. 
4. ELEVATOR

4.1 GENERAL

a. The elevator shall be a 4,000 pound net capacity, hydraulicelectric elevator which shall be designed, fabricated and installed in conformance with ASA AI7.I, Part III.

b. The elevator shall be designed to serve front and back openings at elevations $0^{\prime}-0^{\prime \prime}$ and plus $11^{\prime}-6^{\prime \prime}$, and a front opening only at elevation minus $10^{\prime}-0^{\prime \prime}$ and elevation plus $25^{\prime}-6^{\prime \prime}$ 。

c. The elevator shall be an "Oildraulic" Freight Elevator as produced by the Rotary Lift Division of the Dover Corp., adapted as specified herein, or an approved equal.

\subsection{CAR}

a. The elevator platform shall be 6 feet wide by 9 feet long front to back, and shall be surfaced with smooth steel plate. The platform shall be designed for Class " $C$ " loading as defined in Rule 207, ASA AI7.1.

b. The car shall be enclosed on the sides with sheet steel of not less than 14 gauge. Car height inside shall be 8 feet.

c. A perforated sheet steel top, of not thinner than 16 gauge, or expanded metal not lighter than 14 gauge, shall be provided over the car. The car top shall be supported to withstand a load of not less than 300 pounds on any 4 square feet of area.

d. An emergency escape exit shall be provided in the car top.

e. The elevator car shall be equipped with vertical lift gates, front and back, formed from expanded sheet metal on a steel frame.

f. The car frame shall be formed from rolled structural steel shapes conforming to ASTM A36. Structural members shall be jointed by welding. Castings shall be attached by bolting.

g. The car shall be equipped with two flushmounted 120 volt light fixtures controlled by a switch in the car. 


\section{MATERIALS (Continued)}

\subsection{CAR (Continued)}

h. The car shall have one 120 volt, Twistlock receptacle attached to the car frame $6^{\prime}-6^{\prime \prime}$ above the car floor.

\subsection{TRAVEL SPEEED}

a. The elevator "up" speed shall be 50 feet per minute. Travel speeds shall be rated at capacity load.

b. The elevator shall lower by gravity. The "down" speed shall be capable of regulation within the range 70 to $80 \mathrm{fpm}$.

\subsection{ELEVATOR CYLINDIR AND PLUNGER}

a. The elevator cylinder shall be constructed of steel pipe of sufficient thickness to withstand a test pressure $2_{\overrightarrow{2}}$ times the design working pressure without exceeding the yield strength of the material. The bottom of the cylinder shall be closed and the top provided with a cylinder head equipped with an adjustable packing gland having bronze bearings and a type of packing suitable for use with a readily available petrolevis oil.

b. The plunger shall be constructed of steel pipe turned true and smooth with a fine pollshed finish. Plungers of built-up construction shall be joined by means of intermal couplings. The plunger shall be provided with a stop, welded to the bottc: to positively prevent the plunger from leaving the cylinder.

c. A steel pipe casing shall be provided to contain the cylinder.

a. The elevator cylinder shall be furnished with an exterior coa:i二 consisting of:

(I) a coat of hot asphalt

(2) a wrapping of $15 \mathrm{Ib}$. asphalt-saturated roofing felt

(3) a second coat of hot asphalt

(4) a wrapping of heavy kraft paper 


\section{MATERIAIS (Continued)}

\subsection{POWER SUPPLY}

a. The power supply for the pumping unit is 440 volt, 3 phase, 60 cycle alternating current.

b. The lighting and control circuits shall be 120 volt, single phase, 60 cycle alternating current.

c. All control devices except pushbuttons and signals shall be contained in a single cabinet of NEMA 12 construction,

4.6 POWER UNIT

The power or pumping unit for the elevator shall consist of a positive displacement pump driven by an induction motor with both units mounted on a common bed plate. The pump shall be designed to use a petroleum oil. A permanent nameplate shall be attached to the pump indicating the brand and viscosity of oil recommended by the elevator manufacturer for replacement. Motor shall have magnetic starter with manual reset, type overload relay.

\subsection{AUTOMATIC LEVELING DEVICE}

The elevator shall be provided with an automatic creepage correction device which shall be arranged to maintain the elevator to within $\frac{1}{4} "$ of level with the building floor in the event the elevator should creep down a pre-determined amount below floor level. This device shall be operative at all floors served, whether the hoistway door and/or car gate is opened or closed, provided there is no interruption of power to the elevator. This device shall also bring the car to a stop within $\frac{1}{4}$ " of level with any floor for which a stop has been initiated regardless of load or direction of travel.

\subsection{AUTOMATIC TERMINAL STOPS}

The elevator shall be equipped with an automatic stopping device arranged to bring the car to a stop at the terminal landings independent of the regular operating device in the car.

\subsection{OPERATION}

a. Car operation shall be by single "call" button at each floor and a flush-mounted operating device in the car which shall include

a bank of buttons numbered to correspond to the landings served, a switch for the car light, an alarm buttom connected to a bell 


\subsection{OPERATION}

a. (Continued)

which serves as an emergency signal, and an emergency stop switch. The operating device shall give the persons in the car uninterrupted use of the elevator until the car has reached the desired landing and for a pre-determined interval thereafter to allow sufficient time for the car gate to be opsned.

b. The elevator shall be incperative when the car gate or any of the hois way doors is open.

c. A single call pushbutton shall he provided for mounting adjacent to each hoistway door. A momertary pressure on any such pushbutton shall bring the car to that landing provided the elevator is not in use and provided the car gat,es aja the hoistway doors are closed. After the car stops at a landing in response to a landing call, a time relay shall render the car incperative from other landing buttons for a pre-determineci interval.

d. The car shall be equipped with a well which will ring while a call button is being pressed and a car gate or hoistway door is cpen.

e. A "trcuble" alarm bell, operatod by the alarm button in the car, shail ke provided for mounting outside the hoistway at the plus $11^{\prime}=6^{\prime \prime}$ landing on the east side of the shaft.

\subsection{GUIDE RAIIS AND SHCES}

a. Guide rails for the elevator shall be pianed steel tees designed for fastening to the hoistway walls and framing, by an approved metrod. The ends of guide sejtions shall be tongued and grooved to form matched joints. Stesl splice plates shall be provided.

b. The eleyator car shall be equipped with milled, swivel type guide shoes to engage the guide rails,

c. Cuide rail lubricators shall be furnished for the car to distribute oil to the guide rails.

\section{11 BUFFEFS}

Spring buffers stall be provided, rounted on pit floor or supported on the cylinder hesd. Bufiers ehall be blocked up as required to protect. 


\subsection{BUFFERS (Continued)}

cylinder head and packing gland in the event the car should for any reason pass the bottom limit switch setting. Striking plates shall be provided on underside of car frame to.engage burfers.

\subsection{HOISTWAY DOORS AND INTERLOCKS}

a. Hoistway doors shall be menually operated, all steel, counterbalanced, vertically-sliding, bi-parting doors $6^{\prime}-0^{\prime \prime}$ wide $\times 7^{\prime}-6^{\prime \prime}$ nominal height with replaceable panels made of not less than $\frac{11}{11} 4$ U.S. gauge sheet steel. Whexe headroom is restricted, doors may be more than two panels. Doors and track assemblies shall be supported from the building. structural members and shall not bear on or be supported from the plaster partitions.

b. Doors opening on the west side at the $0^{\circ}-O^{\prime \prime}$ and $1 I^{\prime}-6^{\prime \prime}$ elevations shall be Class "B" labeled fire doors a Fire doors shall bear the label and class stamp of the National Board of Fire Underwriters.

A wire glass window, $8^{\prime \prime} \times 10^{\prime \prime}$, in each upper door panel shall be provided. Each door shall be equipped with an approved interloc: which prevents the operation of the ellevator until all doors are closed and locked.

c. Each upper panel shall include a handlie for opening and a webbed strap or othex means for closing the doors. Door interlocks shall provide that a hoistway door shall remain locked until the elevator arrives at the landing where the door is located.

d. A I" safety astragal shall be provided on the lower edge (meeting rail) of the upper panel of the bi-parting, vertical-sliding doors.

\subsection{OIL RESERVOIR AND PIPING}

a. The oil storage tank for the elevator shall be all-welded steel construction. The tank shall be provided with a tight-fitting steel cover, protected vent opening, an oil level gauge, a filtering screen over the pump suction line outlet and a valved drain connection. The tank shall have a capacity equal to the volume of oil required to lift the elevator too the highest terminal, plus a reserve of at least 10 gallons. 


\subsection{OII RESERVOIR AND PIPING (Continued)}

b. All pipe and fittings for the hydraulic elevator system shall be steel or wrought iron. Threaded connections shall be ASA standard pipe threads.

c. Equipment shall be of a size and so assembled to fit the space provided in room number 20 as shown on H-3-20190. The equipment shall be arranged to provide ease of access for maintenance.

5. DUMBWAITER

5.1 GENERAL

The dumbwaiter shall be a heavy duty, floor-level-loading, traction drive, electric dumbwaiter. The machine shall have a capacity of 500 Ib. net load; shall travel at the rate of 50 feet per minute; and shall. operate on a 440 volt, 3 phase, 60 cycle power supply. The dumbwaiter shall serve openings at $0^{\prime}-0^{\prime \prime}, 11^{\prime}-6^{\prime \prime}$ and $24^{\prime}-6^{\prime \prime}$ building elevations. The dumbwaiter shall stop within tolerance of plus or minus $\frac{1}{4}$ from building floor levels. The design, fabrication and erection of the machine shall conform to the requirements specified herein and in ASA AI7.1, Part VII. The dumbwaiter shall be Energy Elevator Co. Bulletin 405, adapted as specified below, or an approved equal.

\subsection{CAR}

a. The car shall be $2^{\prime}-6^{\prime \prime}$ wide by $3^{\prime}-6^{\prime \prime}$ deep by $4^{\prime}-0^{\prime \prime}$ high, open on the front side only.

b. The car frame shall be formed from stainless steel rolled structural shapes and shall be lined on three sides and at the top with 16 gauge stainless steel sheet metal. The floor of the car shall be stainless steel sheet not thinner than $1 / 8$ inch and shall slope to rear of car at $\frac{11}{4}$ per foot. All stainless steel parts shall be 300 series, comerci $\varepsilon_{-}^{-}$ grade. Inside face of liner sheet shall have a No. 4 finish.

c. The car shall be equipped with a flush-mounted ceiling light fixture and call buzzer. Bronze guide shoes shall be provided to hold the car in alignment with the guide rails. A separate car gate is not required.

\subsection{HOIST MACHINERY}

a. The dumbwaiter hoist shall consist of a close coupled, electric motor- 


\section{MATERIALS (Continued)}

\subsection{HOIST MACHINERY (Continued)}

a. Continued

driven, worm geared, traction type, winch drum designed for two hoist cables. The hoist shall be designed for overhead mounting on structurasteel support beams furnished by the hoist manufacturer and attached to the Hi-Bay Cell wall which forms the south wall of the hoistway.

b. The hoist drum shall be equipped with an adjustable shoe type, electric brake. The drum shall be scored for two hoist cables and shall be equipped with sheave guards.

c. Bearings shall be ball or rollex type, Iubricated from the gear case oil bath.

\subsection{CAR AND COUNIEERWEIGHT GUIDES}

Guide rails shall be rolled structural steel channels weighing 6.0 lb per foot. Guide rails shall have bottom footing plates and terminal safety stops for car and counterweight.

\subsection{DOORS}

a. Service doors at each of the three specifie $\ddot{d}$ levels shall be biparting, Class " $B$ " fire doors. These doors shall bear the stamped label of the National Board of Fire Underwriters.

b. Service doors shall have stainless steel truckable sills and shall be equipped with pressed steel frames and electro-mechanical locks operated by a cam on the car.

c. An access door or doors shall be provided in the north or west wall of the hoistway at the elevation of the dumbwaiter hoist to permit maintenance of the hoisting machinery.

\subsection{CONIROIS}

a. The dumbwaiter control shall consist of full automatic, momentary pressure pushbuttons. A full bank of buttons, numbered for each level to be served, shall be provided at each service door.

b. The control system shall include manual reset overload protection for motor, reversing starter, and timed non-interference operation. The motor starter shall be mounted in the motor control center No. 4 . 


\section{MATERIALS (Continued)}

\subsection{CONIROLS (Continued)}

c. Hoistway control equipment shall include terminal limit switches, floor selector switches and combination locks and electric contacts for hoistway service doors.

\subsection{SIGNALS}

The pushbutton panel adjacent to each door served by the dumbwaiter shall incorporate an Arrival Light to indicate when the car arrives at that landing and an In-Use Light to indicate that the car is in use or that a hoistway service door is open. Fressing the call button, when the car is standing at a landing with the door open shall sound the buzzer mounted on the car ceiling.

\section{PAINTING}

a. All ferrous surfaces including car walls, floor and ceiling surfaces, doors, car gates, structural and miscellaneous members of elevator and dumbwaiter shall receive a heavy coat of rust inhibitive primer at the factory. Contact surfaces of moving parts shall not be painted.

b. The elevator hydraulic machinery, including electric motors shall have factory applied enamel finish, color gray.

c. Final painting of elevator car interior, elevator car gates and doors and dumbwaiter doors after erection shall be done in accordance with Division XVI of this specification.

\section{WORIMANSHIP}

\section{EIEVATOR INSTAITATION}

\subsection{WIRING}

a. The Contractor shall furnish and install complete, all necessary insulated wiring to connect all parts of the equipment. All wire, except traveling cables, shall have a flame retarding and moisture resisting outer cover and shall be run in metal conduit, metallic tubing, wire ducts or raceways. 
WORKMANSHIP (Cont)

\subsection{WIRING (Continued)}

b. Traveling cables shall be flexible and suitably suspended so that there is no strain on the individual conductors. All electrical material and work shall comply with the requirements of Division XVII and the elevator manufacturers wiring diagrams.

\subsection{CYLINDER WEIL}

a. Excavation of the cylinder well. may be done by any customary process which does not disturb the bearing for adjacent building foundations. A steel pipe casing shall be installed in the well to contain the cylinder.

b. When the elevator cylinder has been placed in the well and properly supported and aligned the annular space between the cylinder and the well casing shall be filled rith $1 / 4$ " minus sand. The sand shall de compacted into place with a vibrator, of the type used in placement of concrete, until settlement of the material is complete.

\section{$7 \cdot 3$ INSTALLATION OF GUIDE RAILS}

Guide rails shall be attached to the hoistway walls by a method approved by the Commission. Rails shali be shimmed straight and plumb. Steel splice plates shall be fastened between sections of rail and the rails Iubricated before the car is lifted.

\subsection{POWER UNIT AND OIL RESERVOIR}

a. The elevator power unit, electric controller and oil reservoir shall be installed in Room 116 A shown on drawing H-3-20160. All units of equipment shall be anchored to floor or walls as indicated on the elevator manufacturer's drawings.

b. Piping, valves and fittings shall be installed between the tank, power unit, hydraulic controller and the cylinder in accordance with the elevator manufacturer's piping drawings. In addition to the valves required for normal operation, a gate valve shall be installed in the supply line to the cylinder.

c. An initial supply of oil, sufficient for proper operation of the elevatcr. with reserve as specified herein shall be supplied and installed by the Contractor. 
8. DUMBWAITER INSTAIJATION

a. The dumbwaiter hoisting mechanism supports shall be attached to the concrete wall of the hoistway. Vibration isolators shall be installed between the hoist and the steel support beams.

b. The guide rails shall be attached to the hoistway talls or to supplementary steel framing supplied by the dumbwaiter manufactirer. Rails shall be straight and plumb.

c. Electric wiring shall be as shown on the dumbwaiter manufacturer's wiring diagrams and shall be installed as specified in Division XVII. All switches, relays and controls shall be connected to permit the dumbwaiter to function as specified by the manufacturer and herein.

9. INSPECTION AND TESTING

a. At the completion of installation of the elevator and dumbwaiter each machine shall be given a full load functional test in the presence of the Commission.

b. All pushbutton controls, lights and automatic controls shall be operated to verify compliance with the requirements stated herein. Doors interlocks at all floors shall be checked and leveling tolerances verified. 
PAINTING, PROTECTIVE COATING \& FLOOR COVERING

\section{GENERAL}

\section{SCOPE}

This division covers painting, special protective coating work and floor covering for the Fuels Recycle Pilot Plant, Building 324, except for standard products of approved manufacturer's which are normally finished by painting in the manufacturer's plant and except for special interior coating of the Exhaust Stack covered in Division XXIV.

2. REFERENCED STANDARDS AND SPECIFICATIONS

The standards and specifications listed below form a part of this specification to the extent indicated by subsequent references.

2.I AMERICAN STANDARDS ASSOCIATION (ASA)

ASA 108.3 - 1958, Specifications for Installation of Quarry Tile and Pavers in Cement Mortars

\subsection{FEDERAL SPECIFICATIONS}

L-T-00345, Tile, Floor, Vinyl Asbestos SS-T-308b, Tile Ceramic, Floor, Wall and Trimmers SS-W-00110, Water Repellant, Colorless, Silicone Resin Base TT-P-0029a, Paint, Latex-Base, Interior, Flat TT-P-56b, Primer Coating (primer-sealer) Pigmented Oil, Plaster and Wallboard

TT-P-86a(1), Paint, Red-Lead Base, Ready Mixed

TT-E-487, Enamel, Floor and Deck

TT-E-489c, Enamel, Alkyd, Gloss

TT-E-527a, Enamel, Synthetic, Lusterless

TT-E-529a, Enamel, Alkyd, Semi-Gloss

TT-E-545a, Enamel Undercoat, Alkyd, Interior

TI-P-64lb, Paint, Primer, Zinc-Dust Zinc-Oxide

\subsection{U.S. MARITTME ADMINISTRATION}

USMA 52-MA-202, Zinc Chromate, Alkyd Base 
2. REFERENCED STANDARDS AND SPECIFICATIONS - Continued

2.4 HANFORD STANDARD SPECIFICATIONS

HWS-53ll-S, Rev. 1, Identification of Piping Systems

2.5 STEEL STRUCTURES PAINTING COUNCIL (SSPC)

SSPC-PT2-53T - Cold Phosphate Surface Treatment

SSPC-SPI-52T - Solvent Cleaning

SSPC-SP3-52T - Power Tool Cleaning

SSPC-SP5-52T - Blast Cleaning to "White" Metal

SSPC-SP6-52T - Commercial Blast Cleaning

3. QUALIFICATION OF SPECIAL PROTECTIVE COATINGS

If the Contractor proposes to use Special Protective Coatings other than those named herein he shall submit certified reports from independent laboratories showing the results of tests to determine conformance to the requirements stated herein. The certified laboratory reports shall be submitted to the Commission within 60 days after issuance of the Notice to Proceed in order to be considered for approval.

4. PAINT MATERIAIS

a. Sealer for concrete block walls exposed to the weather shall conform to the requirements of Federal Specification SS-W-00110. Same material shall be used on interior walls where specified on the drawings.

b. Primer for structural and miscellaneous carbon steel shall conform to Federal Specification TT-P-86a or USMA 52-MA-202.

c. Primer for galvanized metal shall conform to USMA 52-MA-202.

d. Primer-sealer for interior masonry and concrete shall conform to Federal Specification TT-P-56b.

e. Enamel undercoat, for surfaces specified to be finished with enamel, shall conform to Federal Specification TT-E-545a.

f. Wherever enamel is specified in the Finish Schedules (drawings H-3-20174 \& 175) other than for floors the material used shall be an alkya, gloss enamel conforming to Federal Specification TT-E-489c Class A. 
4. PAINT MATERIALS - Continued

g. Enamel for floors shall be a material made specifically for floor service and conforming to the requirements of Federal Specification TT-E-487.

h. Where semi-gloss enathel is shown the material shall conform to Federal Specification TT-E-529a, Class A.

i. Where lusterless enamel is specified, the material shall conform to Federal Specification TT-E-527a.

j. Where "rubber-base" paint is specified in the Finish Schedules on the drawings the material used shall be a latex emulsion conforming to Federal Specification TT-P-0029a.

\section{SPECIAL PROTECTIVE COATINGS}

\subsection{CRP-I}

a. The chemical resistant paint (CRP-I) to be applied at the locations designated on drawings $\mathrm{H}-3-20174$ and 75 , shall be a phenolic or epoxy base resin material formulated for air curing at room temperatures.

b. To qualify for the service intended, the coating shall have withstood 30 day, room temperature, imnersion tests in the following solutions without swelling, softening, becoming sticky, sloughing, blistering, disintegrating, dissolving, losing adhesion between coats or to the coupon, discoloring the solution or more than mildly discoloring the coupon:
(1) $10 \%$ nitric acid
(2) $10 \%$ phosphoric acid
(3) $10 \%$ sulphuric acid
(4) $10 \%$ hydrochloric acid
(5) $10 \%$ caustic soda
(6) Xylene
(7) Methyl isobutyl ketone
(8) High purity water (500,000 ohms specific resistance)

c. CRP-I shall resist abrasion to the extent that it will show not more than 0.160 grams weight loss per 2500 cycles in the Standard Taber Abraser test using a CS -17 wheel with a 1000 gram load. Loss of film thickness shall not be greater than 0.002 inches under the same conditions. Abrasion tests shall not be made on coating samples on which coating has been hardened by baking. 


\section{SPECIAL PROTECTIVE COATINGS}

\subsection{CRP I - Continued}

d. CRP-I coating system shall have successfully withstood a radiation exposure of $1 \times 10^{9}$ roentgens without damage other than slight discoloration, such as changing white coating to cream color. Damage shall be interpreted to mean any of the defects mentioned in paragraph $b$. above.

e. Coating for CRP-I service shall be Carboline Co. "Phenoline" 300 system or Amercoat Corp. "Amercoat," No. 74 system, or approved equal. Color samples of the coating system to be used shall be submitted to the Commission for approval. Samples will be used for comparison with the finished work.

\subsection{CRP-IA}

a. The coating for submerged service in the Wet Basin shall meet all the requirements specified in section 5.1 above for CRP-I, except for immersion tests in hydrochloric, sulphuric and phosphoric acids, but need not be the same generic type.

b. In addition CRP-IA shall have a low permeability rate in water. The moisture vapor transmission rate shall not exceed 0.7 grams per 100 square inches per 24 hours at $95 \mathrm{~F}$. with a pressure differential of $0.75 \mathrm{psi}$.

c. The CRP-IA coating system shall have good bond strength to both concrete and steel, shall be applied in not less than 4 coats, and shall have a dry film thickness of $30 \mathrm{mils}(0.030$ inches) or more.

d. The CRP-IA coating system shall be one of the following, or an approved equal system:

(1) Carboline Co. "Phenoline 300-302" four coat system applied as:

1 coat No. 300 AE Primer

1 coat No. 302 Black

1 coat No. 302 Green

1 coat No. 300 Finish White

with a total ary film thickness of 30 mils $\left(0.030^{\prime \prime}\right)$. 


\section{SPECIAL PROTECTIVE COATINGS}

\subsection{CRP-IA}

d. (Continued)

(2) Amercoat Corp. "Amercoat 66" five coat system applied as:

1 coat No. 66 Primer

1 coat No. 66 Surfacer

1 layer open weave $(12 \times 18)$ glass cloth

I coat No. 66 Surfacer

2 coats No. 66 Seal Gloss

with a total dry film thickness of $30 \mathrm{mils}\left(0.030^{\prime \prime}\right)$.

\subsection{CRP-II}

a. The coating system to be used where CRP-II is designated on the Finish Schedules, drawings $\mathrm{H}-3-20174$ and 75 , shall be a polyamidecured epoxy coating.

b. To qualify for the service intended, the coating used shall have been demonstrated to be suitable for the conditions listed below without cracking, peeling, blistering, or loss of adhesion:

(1) Single coat application (not less than $3 \mathrm{mil}$ dry film) on concrete or shop-primed steel (see Division IV) where it will be subjected to mild chemical fumes, wash-down with household detergent in water but no foot or vehicle traffic (such as on uper walls and ceilings).

(2) Being over-coated with CRP-I after 6 months air curing.

c. Carboline Co. "Epoxy 190", or approved equal, shall be used where CRP-II is specified on the Finish Schedule, drawings $\mathrm{H}-3-20174$ and H-3-20175. Color samples shall be submitted to the Commission for approval. Approved color samples will be used for comparison with the finished work.

\section{FLOOR COVERINGS}

\subsection{VINYL-ASBESTOS TILE}

a. Vinyl-asbestos floor tiles, where shown on the Finish Schedules on drawings $\mathrm{H}-3-20174-75$, shall be $3 / 32$ " gauge and shall conform to the requirements of Federal Specification I-T-00345. Feature strips shall be black vinyl-asbestos 4 " wide. 


\section{FLOOR COVERINGS}

\subsection{VIRIL-ASBESTOS TIIE - Continued}

b. The following tile color and pattern numbers shown on the Finish Schedules shall be Armstrong Cork Co. "Excelon", or approved equal.
(1) No. 861 - Ancestral White
(2) No. 869 - Ivory Tan
(3) No. 876 - Wild Honey

c. The following tile color and pattern numbers shall be Mastic Tile Division of the Rubberoid Co. "Matico", or approved equal.
(1) No. 3000 - Marbelized blue with white
(2) No. 3813 - Marbelized pearl gray with white, chalk blue and copper

d. Cement for laying vinyl-asbestos tile shall be a waterproof type suitable for adhering tile to concrete on-grade. Armstrong's S-90 is an example of the type required.

\subsection{QUARRY TILE}

a. Quarry tile shall be 6" $\times 6 " \times 1 / 2^{\prime \prime}$ non-vitreous, natural clay tile with plain face and shall conform to the requirements of Federal Specification SS-T-308b, TJpe I, Class C. Tile color and surface shall be Mosaic Tile Co. "Carlyle Greytone" No. 140, or approved equal. The Contractor shall furnish two samples of the tile he proposes to use to the Commission for color comparison and approval prior to purchase of the material.

b. Ingredients for mortar bedding for quarry tile shall conform to the requirements stated in Section 6 , Division II of this specification, except that cement for pointing mortar shall be white masonry cement.

\section{EPOXY TOPPING CEMENT}

Epoxy cement for constructing door sills as shown on drawing H-3-20l72 shall be an epoxy resin material with washed and graded silica filler. Sills shall be built up with resin containing filler and finished with a coat of resin without filler. Color shall be light gray. Topping cement shall be Permagile Corp. of America, "Permatop"; or Carboline Co. "Epoxy No. 183", or approved equal. 
8. $\quad$ COCOA MAT

Cocoa fiber mat for entry shall be $22^{\prime \prime} \times 36^{\prime \prime} \times 11 / 2 "$ thick. Mat shall be Arafe Rubber Co. "Giraffe" brand; Koffler Sales Corp. "Fiber King", or approved equal.

\section{WORKMANSHIP}

9. HANDLING AND STORAGE OF PAINTS AND COATINGS

a. All paint and coating materials shall be delivered to the job site in the manufacturer's original containers with labels intact and seals unbroken.

b. Paint and coating materials shall be carefully handled and shall be stored in accordance with the manufacturer's recommendations and in a well-ventilated place where they will not be exposed to excessive heat, smoke, sparks, flame, or direct rays of the sun.

c. Paints and coating shall not be mixed within $25 \mathrm{ft}$. of stored materials.

d. The Contractor shall take all necessary precautions to prevent fires. Rags, waste, paper, or other materials that have become spotted or soaked with paint, coatings, oil, or solvents shall be placed in closed metal containers and disposed of each day. The Contractor shall furnish and maintain the closed metal containers at the work site.

10. SURFACE PREPARATION FOR PAINTING

Surfaces to be painted shall be prepared as specified below:

a. The minimum surface preparation for carbon steel to be painted shall be in accordance with the requirements of SSPC-SP3.

b. Galvanized and zinc-coated surfaces shall be prepared for painting by solvent cleaning in accordance with SSPC-SPI.

c. All concrete and plaster surfaces to be painted shall be aged 4 weeks minimum prior to painting. Plaster surfaces which are too smooth for proper adherence of paint shall be roughened by sanding lightly with $2 / 0$ sandpaper.

d. Damage to shop coats shall be touched-up prior to application of succeeding coats. 


\section{SURFACE PREPARATION FOR PAINTING - Continued}

e. All surfaces to be painted shall be dry and free from dirt, grease, oil, weld spatter and other foreign materials prior to applying paint.

f. Paint materials shall not be applied until surface preparation has been approved by the Comission.

11. PAINT MIXING

a. Ready-mixed oil paints, in original containers, shall be vibrated in a power driven vibrator-type paint mixer for a period of from three to ten minutes to remove all heavy sediment from the bottom of the can. The entire quantity shall then be "boxed" and strained through a fine wire screen or cheese-cloth before using.

b. Ready-mixed enamels shall be thoroughly stirred in small quantities and "boxed" for uniformity.

c. Paint shall not be mixed when the paint or surrounding air temperature is less than $50 \mathrm{~F}$.

\section{PAINTING}

a. Finished hardware, glass, stainless steel and floor tile surfaces shall not be painted. Aluminum surfaces such as vent ducts, grating, etc., shall not be painted except where specified on the Finish Schedule.

b. The Contractor shall take all necessary precautions to protect surfaces not to be painted.

c. Paint shall be applied in conformance with the "Painting Schedule", of this division of the specifications.

d. All paint materials shall be applied and spread with care to a uniform film thickness, showing no runs, sags, crawls, brush marks, oversprä: or other defects.

e. Painting shall not be done when the ambient temperature of the surface temperature is below $50 \mathrm{~F}$, without written permission from the Commission.

f. Painting shall not be done when the atmospheric humidity is greater than 80\%; or when dusting operations are in progress nearby; or when surfaces are damp to touch or frosty. Only thoroughly clean 


\section{PAINTING - Continued}

\section{f. (Cont.)}

and dry surfaces shall be painted. A minimum of 24 hours shall elapse between coats of paint.

g. All finished work shall be free from defective brushing, or clogging of lines and angles. Edges of paint adjoining other colors or materials shall be clean and sharp without overlapping.

h. "Wet Paint" signs shall be posted to protect newly finished surfaces from damage.

i. Rags or other material which have become spotted or soaked with paint materials shall not be permitted to accumulate anywhere inside of buildings except in closed metal containers during working hours and shall not be left within any building after working hours.

j. All surfaces of structural steel or steel siding which are in contact with concrete and/or will be inaccessible for painting after erection shall receive 2 coats of finish paint, as specified in the Painting schedule, before being erected. This requirement does not apply to surfaces to be embedded in concrete.

k. Paint coats shall be applied with succeeding coats in contrasting colors and finished with the specified final color. Color contrast between coats shall meet the approval of the Commission.

1. Where specified on the drawings, surfaces of masonry walls shall be sealed with 2 coats of the clear silicone water repellant coating specified. Coating shall be applied in accordance with the coating manufacturer's directions after the masonry has been thoroughly cleaned.

m. Equipment Piece Numbers (EPN), shown in Divisions VI, X, XVII and XX for various types of equipment, shall be painted on the equipment using gloss enamel. Letters and numbers shall be block characters not less than one nor more than 2 inches high. Black enamel shall be used on gray and lighter colored backgrounds and white enamel on deep blue, red and darker backgrounds. These requirements shall also apply to identification legends specified in Division XVII.

\section{PAINTING SCHEDULE}

\section{I INTERIOR SURFACES}

a. Where sealer is specified for masonry walls, 2 coats of silicone sealer, per Federal Specification SS-W-OO110, shall be applied. 


\section{PAINTING SCHEDULE}

\subsection{INTERIOR SURFACES - Continued}

b. Plaster, concrete and masonry to receive a pigmented finish shall be primed with one coat of primer-sealer per Federal Specification TT-P-56b.

c. Surfaces to receive enamel finishes shall be given one coat of enamel undercoat (F.S. TT-E-545a) over the specified primer and finished with one coat of the enamel specified.

d. Surfaces to be finished with "rubber base paint" shall be given 2 coats of the finish over the specified primer.

e. Aluminum and galvanized surfaces to be painted shall be primed with one coat of zinc chromate, per USMA-52-MA-202.

f. All interior piping shall be identified in accordance with Hanford Standard Specification HW-5311-S.

g. All ferrous metal items received at the jobsite without a shop coat of paint, other than items to be embedded in concrete, shall be primed with red-lead (F.S. TT-P-86a, Type II) or zinc-chromate (52-MA-202).

\subsection{EXTERIOR SURFACES}

a. Exterior concrete block walls shall be given 2 coats of clear silicone sealer, Federal. Specification SS-W-00110.

b. Exterior metal surfaces shall receive 2 coats of alkyd enamel over the specified primer. Gloss of finish shall be as indicated by color numbers on drawing H-3-20175.

c. Door frames No. 102 and No. 103 shall be painted to match adjacent tubular columns and window militions. 


\section{SURFACE PREPARATION FOR SPECIAL PROTECTIVE COATINGS}

\subsection{METAI SURFACES}

a. Metal surfaces to receive CRP-I and CRP-IA shall be sandblasted to "white metal" in accordance with SSPC-SP5. This includes grating in the Chemical Makeup platform (Room 309) and over Truck Lock Sump (Room 138).

b. Metal surfaces to receive CRP-II which have been shop-primed as specified in Division IV, shall be touched up and then coated with CRP-II finish after removal of dust and oil. Ferrous metal items which are received unprimed or fabricated at the job site and are to receive CRP-II shall be sandblasted in accordance with SSPC-SP6 and given a prime and finish coat of CRP-II.

\subsection{CONCRETE, PIASTER \& MASONRY SURFACES}

a. Concrete surfaces to receive CRP-I, IA or II shall have been given an F-4 finish (see HW-4798-S for definition of F-4) as specified in Division II. If the concrete finish has been marred or damaged in any way prior to coating it shall be repaired with latex-cement surfacer specified in Division II, Section 11. The same shall apply for concrete block surfaces which have become damaged.

b. Concrete surfaces to be coated which are glazed or too smooth for proper adherence of the coating, as determined by the commission, shall be etched with a solution of muriatic acid (1 part hydrochioric acid to 4 parts water). When solution stops bubbling all traces of acid shall be removed by rinsing with clean water. The process shall be repeated if the surface does not show sufficient "tooth" or profile for proper adherance of the coating.

c. All cracks which develop in the concrete in the Wet Basin shall be cut out approximately 1/4" wide at surface by 1/4" deep and filled with epoxy-polysulphide compound, Carboline Co. No. 225, or approved equal, by the General Contractor, prior to coating application.

d. If the coating manufacturer's specification recomends surface preparation other than that stated herein it shall be done in adition to the requirements stated here.

e. Plaster surfaces which are too smooth for proper adherence of the coating as determined by the Commission shall be sanded lightly with $2 / 0$ sandpaper. Dust shall be removed with brush and vacuum.

f. Coating materials shall not be applied until the surface preparation has been approved by the commission. 


\section{APPLICATION OF CHEMICAL RESISTANT COATINGS}

a. The Contractor shall take all necessary precautions to protect surfaces not to be coated.

b. Coatings shall be applied in conformance with the "Coating Schedule" in this division of the specifications.

c. Spraying and/or other application equipment for chemical resistant coatings shall be as recommended by the coating manufacturer.

d. Preparation of material, cleaning of surfaces, and application of coatings shall be performed in strict accordance with the coating manufacturer's puilished recommendations. Coatings shall be applied to not less than the thickness required in the "Coating Schedule" included in this Division.

e. Sandblasted surfaces of metal shall be primed as soon as possible after sandblasting. In all cases surfaces shall be primed not later than 8 hours after being sandblasted. The first body coat shall be applied not later than 48 hours after surface has been primed.

f. Coatings shall not be applied when the ambient temperature or the surface temperature is below $50 \mathrm{~F}$.

g. Solvent fumes in some of the coating solutions are hazardous for breathing and are also flammable. When the coating is to be applied in confined locations, forced air circulation shall be provided and personnel shall wear fresh air masks during application. Work shall not be done near a source of ignition. Matches, torches, and smoking shall be prohibited in these locations. Air circulation must be maintained during application and curing.

h. Surface cracks or openings not covered or filled with the first coating application shall be filled in accordance with manufacturer's recommendations prior to applization of succeeding coats. Filled surfaces shall be coated same as remainder of surface.

1. To insure complete coverage, successive coats shall be applied in alternate colors, finishing with the desired final color.

j. Manufacturer's instructions on pet life of coating and cleaning of equipment shsll be rigidly observed.

k. Each coat of special protective cottings shall be free of "orange peel" effect, overspray, embedied or partially embedded particles, craters, finholes, "holidays" or other defects.

1. A K-D Company Bird Dog Detector, or minxer and Rasor M-I Detector, shall be used to check for holidays and pinholes on coated metal surfaces. 
16. COATING SCHEDULE

16.1 CRP-I

a. For floors, stairs, slabs, Damper Pit, Sampler Room (No. 145) and interiors of process cells:

(1) "Amercoat" epoxy coating system or approved equal, shall be a minimum of 0.010 inches in thickness applied as: 1 coat No. 74 Primer; 2 coats No. 74 Body coat and 2 coats No. 74 Seal.

(2) "Phenoline" coating system (more than $85 \%$ solids content) or approved equal, shall be a minimum of 0.020 inches in thickness applied as at least two coats of "Phenoline" 300.

b. For walls and ceilings and locations not subject to abrasion of foot and vehicle traffic and all interior surfaces of Zone I exhaust tunnels:

(1) "Amercoat" epoxy system or approved equal, shall be a minimum of 0.006 inches in thickness applied as one coat No. 74 Prime, one coat of No. 74 Surfacer and a minimum of two coats of No. 74 Seal.

(2) "Phenoline" system or approved equal, shall be a minimum of 0.010 inches in thickness applied as one coat of No. 305 prime and one coat No. 305 Finish.

c. All carbon steel surfaces of decontamination stall shall be coated the same as specified for concrete in paragraph a. above.

d. Coating thicknesses specified above shall be verified by cutting $I^{\prime \prime} \times 2^{\prime \prime}$ coupons from the finished work and measuring the thickness with a micrometer. Coupons shall be taken at the discretion of the Commission but not more than one per 500 square feet unless the coating thickness is found to be deficient. Deficiencies in coating thickness shall be corrected by applying one or more seal coats. Surfaces laid bare by the removal of coupons shall be repaired, at the Contractor's expense, in the same manner as application of the original coating.

\subsection{CRP-IA}

a. Amercoat No. 66 epoxy coating system or approved equal shall be a minimum of 0.030 inches in thickness applied in not less than 5 coats, with a layer of glass cloth embedded between coats of Surfacer as specified in Section 5.2 d. above.

b. "Phenoline" coating system or approved equal shall be a minimum of 0.030 inches in thickness applied in not less than 4 coats as specified in Section 5.2 d. above.

c. CRP-IA coating thickness shall be tested the same as specified for CRP-I in paragraph $16.1 \mathrm{~d}$. above. 
16. COATING SCHEDUTE

16.2 CRP-IA - Continued

a. CRP-IA shall be applied to all floor, wall and curb surfaces of the Wet Basin except that stainless steel and aluminum surfaces shall not be painted.

16. 3 CRP-II

a. On concrete floors the polyamide epoxy (CRP-II) shall be applied to a thickness of 0.005 inches in not less than 2 coats (one primer, one finish).

b. On concrete and masonry walls and ceilings CRP-II shall be applied in one finish coat to a thickness of 0.003 inches minimum.

c. On steel items, primed as previously spectfied, CRP-II shall be applied in one finish coat to a thickness of 0.003 inches. On steel items which have not been shop coated with red lead or zinc chromate, CRP-II shall be applied to a thickness of 0.005 inches in not less than 2 coats applied as one primer, one finish. (This includes interior surfaces of carbon steel exhaust ducts and filter holders for Hot Metallurgical Cells).

d. Hot-dip - galvanized surfaces, such as pipe and ductwork, shall be treated with phosphoric acid pretreatment per SSPC-PI2, rinsed clean and dried prior to applying CRP-II. Following pretreatment CRP-II shall be applied as one prime coat and one finish coat to a thickness of not less than 0.005 inches.

17. INSTALIATION OF FLOOR COVERINGS

\subsection{VINYL ASBESTOS TILE}

a. Vinyl asbestos tile shall be applied on the stairs and concrete floors of the rooms indicated in the Finish Schedule, drawing $\mathrm{H}-3-20174$ and 75 .

b. Vinyl asbestos tiles shall be cemented in place with an adhesive furnished by the manufacturer of the tile.

c. Colors and patterns shall be as shown on Finish Schedule.

d. Feature strips in black ahall be placed in the locker rooms, where shown, for zoning purposes.

e. Aluminum edge mouldings shall be installed where tile terminates at doorways which do not have thresholds. 
17. INSTALLATION OF FLOOR COVERINGS

\subsection{VINYL ASBESTOS TILE}

e. Tiles shall be applied prior to fastening metal cove strip in place at junctions with walls.

f. Tile cement shall be applied only to clean, dry floor surfaces. Surfaces to be tiled shall be free from dust, dirt, grease and oil and shall be thoroughly dry. Concrete floors shall be cleaned by vacuuming immediately prior to applying tile cement.

\subsection{QUARRY TIIE}

a. Concrete in Entry and Lobby floor slab shall be placed to the proper elevation to allow for application of quarry tile and setting bed (see drawing H-3-2054I).

b. Quarry tile shall be set in a bed of Portland cement mortar 1 inch thick. Application shall conform to the requirements of ASA Al08.3, except that cement for pointing and grcuting mix shall be white cement.

c. Bull nose tiles shall be used at the edges of the recess for the floor mat.

d. References in ASA Al08.3 to reinforcement, cleavage membrane and dope coat shall be disregarded.

\section{$17 \cdot 3$ CEMENT DOOR SILIS}

a. Where door thresholds are shown on the drawings to be formed from epoxy topping cement, the preparation of surfaces, mixing of ingredients and the application of the cement shall comply with the cement manufacturer's recommendations.

b. The topping cement shall not be applied in layers greater than $1 / 2$ " in thickness, to provide for the dissapation of heat generated by the reaction of the ingredients and to prevent subsequent cracking.

c. The thresholds shall be formed in straight lines with tops perfectly level in order that weatherstripping will fit properly.

a. Thresholds shall be finished with a $1 / 16$ " thick coat of resin cement containing no aggregate. 
DIVISION XVII

ELECTRICAL

GENERAL

1. SCOPE

This division covers electrical work for the Fuels Recycle Pilot Plant, Builoing 324. Substation and main switchgear equipment is specified in Division XVIII. Communication and alarm equipment is specified in Division XIX.

\section{SUBMISSION OF DRAWINGS AND INFORMATION}

a. The Contractor shall furnish to the Commission dimensional outlines, complete wiring aiagrams, installation instructions, maintenance instructions, performance data and specifications for the equipment specified herein in accordance with the Special Conditions.

The drawings and information shall be furnished in two categories as follows:

(1) Drawings and information submitted for approval and comment prior to purchase and installation.

(2) Certified drawings and information submitted for the permanent files showing equipment as furnished and installed.

b. Data in the category $2 a(1)$ only shall be required for panel boards; drytype transformers; fabricated assemblies such as control stations, relay panels, and terminal boxes; welding outlets; lighting fixtures; automatic emergency lighting units, cathodic protection rectifier; 5 and $15 \mathrm{KV}$ cable; interlocked armored cable, wire ducts, wireways, and cable trays.

c. Data in both the first and second categories shall be required for the motor control centers and fire alarm system.

d. Drawings and specifications shall be submitted for approval, of all equipment and materials which are being furnished as an "approved equal" to equipment and material called for on the drawings and specifications.

e. Material or equipment purchased or installed without prior approval may be rejected.

\section{REFERENCED STANDARDS AND SPECIFICATIONS}

The standards and specifications listed below form a part of this specification to the extent indicated by subsequent references. 
3.1 AMERICAN STANDARDS ASSOCIATION (ASA)

ASA 0 5.1-1948

Specifications and Dimensions for Wood Poles

ASA C $78.1305-1962$

Electrical Discharge Lamps (Mercury), 400 Watt

ASA Z 55.1-1959

Gray Finishes for Industrial Apparatus \& Equipment

3.2 AMERICAN SOCIETY FOR TESTING AND MATERIAIS (ASTM)

ASTM A218 Zinc Coated Steel Wire Strand, Class C

\subsection{AMERICAN WOOD PRESERVERS ASSOCIATION (AWPA)}

AWPA C7-1958 Incised Pole Butts, Preservative Treatment by Non-Pressure Process

AWPA MI-1954 Purchase and Preservation of Forest Products

AWPA P1-1954 Creosote

AWPA P8-1961 Oil Borne Preservatives, Pentachlorophenol

AWPA P9-1962 Standard for Petroleum Used in Pentachlorophenol

3.4 FEDERAL SPECIFICATIONS

WW-C-581 c Conduit, Electrical, Steel, Zinc-Coated

WW-T-806 b Tubing, Electrical, Metallic

WW-C-540 a Conduit, Metal, Rigid (Aluminum)

W-P-131 a Panelboards (Equipped with Automatic Circuit Breakers)

\subsection{HANFORD STANDARD SPECIFICATIONS}

HWS-8000-S, Rev. 5 Motor Control Centers, 600 volt

HWS-8002-S, Rev. 4 Thermoplastic Insulated Wire and Cable

HWS-8003-S, Rev 3 Synthetic Rubber Insulated, Jacketed Wire and Cable, 600 Volt

HWS-8004-S, Rev. 0 Thermoplastic Insulated, Jacketed Control Cable, 300-1000 Volt

HWS-80c6-S, Rev. 3 Butyl Rubber Insulated, Jacketed Cable, 5 and $15 \mathrm{KV}$

HWS-8007-S, Rev. 2 Interlocked Armored Cable, 600 Volt, 5 and $15 \mathrm{kV}$

HISS-8200-S, Rev. 1 Industrial Fluorescent Lighting Units

3.6 HANFORD STANDARDS
$D-2-2 a$
$9^{\prime}-2^{\prime \prime}$ Crossarm
$D-2-2 b$
8'-0" Crossarm
$\mathrm{D}-2-2 \mathrm{C}$
$5^{\prime}-7^{\prime \prime}$ Crossarm
$D-2-2 d$
$10^{\prime}-0^{\prime \prime}$ Crossam
$D-2=78$
Pole Riser Assembly, Non-Metallic Duct Line
$D-2-7 D$
Pole Roser Assembly, Steel Conduit Line
$D-3-3 a$
Distribution Grounding Assembly, Personnel Operated Equiprent
$D-3-3 c$
Distribution and Telephone Grounding Assembly, with
D-4-1a. Galvanized Ground Rods
$D-4-1 b$
$D-4-1 C$
Concrete Cone Anchor
$D-4-1 d$
Extra Light Duty Hoxizontal and Down Gưy Assemblies
Light Duty Horizontal and Down Guy Assemblies
Medium Duty Horizontal and Down Guy Assemblies 


\subsection{FANEORD STANDARDS (Continued)}

D-4-Ie Heavy Duty Horizontal and Down Guy Assemblies

D-4-If Extra Heavy Duty Horizontal and Down Guy Assemblies

D-6-85

D-12-150 Lights on Buildings

D $-15-1$

D-15-20a

$D-15-48$

$\mathrm{D}-15-50$

$D-15-51$

D-20-10

13.8 KV Trarsition - Open wire to Underground

1 \& 2 Duct Underground Conduit, Concrete Encased

Typical Sump for Underground Steel Conduit

Underground Cable Marker

Typical Line Manhole, Concrete

Typical Corner Manhole, Concrete

System \& Equipment. Grounding, Basic Requirements and

Conductors

D-20-10a

System \& Equipment Grounding, Services, Panels and Conduits

$D-20-10 b$

System \& Equipment Grounding, 120/240 and 120/208 Volt

Systems

D-20-10c

$\mathrm{D}-20-10 \mathrm{~d}$

$\mathrm{M}-2-18$

System \& Equipment Grounding, 480 and 277/480 Volt Systems System \& Equipment Grounding, Ground Conductor Connections Safety Showers for Heated Installations

\subsection{ITATIONAL ELECTRIC MANUTACTURERS ASSOCIATION (NEMA)}

NEMA. AB 1-1959 Molded Case Circuit Breakers

3.8 MAIONAI FIRE PROTECTION ASSOCIATION (NFPA)

NFPA-70, 1962 National Electrical Code

NFPA-72, 1962 Proprietary Auxiliary and Local Protection Signaling Systems,

WFPA-73, 1962 Municipal Fire Alarm Systems

3.9 MATIONAI BUREAU OF STANDARDS

National Electrical Safety Code (NESC), 1959

3.10 WSHINGTON STATE DEPARTMENT OF IABOR AND INDUSTRIES

Rules for Instailing Electric Wires and Equipment, 1954

3.11 EDISON ELECTRIC INSTITUTE (EEI)

DD-90, 1960 Douglas Fir Crossarms

\section{MATERIAIS}

\section{STAIDARDS FOR MATERTALS}

a. Materials and equipment shall be new and as specified on the drawings and this specification, or the approved equals (see Section 2d and 4c). The listing of particular equipment or material shall not be construed as all of the materials or equipment required to complete the job and place it in satisfactory operating condition. 
4. STAINDARDS FOR MATERIAIS (Continued)

b. Materials and equipment shall conform to the National Electrical Manufacturer's Association (NEMA) or NEC Standards if such standards have been established for the particular materials and equipment. NEMA Standards for performance shall also apply.

c. Materials or equipment that are not listed as being approved for the intended service by Underwriter's Laboratories, Inc., shall not be accepted as substitutes for materials or equipment that are UL approved.

5. POLES

Poles shall be western red cedar cut from live stock and shall conform to ASA 0 5.1. All poles shall be conditioned and air-seasoned in accordance wi.th the AWPA MI. All poles shall be incised above and below the standard ground line, and butt treated with either creosote or pentachlorophenolpetroleum solution in accordance with AWPA C7. Each pole shall be branded on the butt to designate the class and length of pole; and shall be branded on the face at about 6 feet above the standard ground line but not less thar I2 feet above the butt. The face brand shall designate the supplier's code or trade-mark, plant location, year of treatment, species and preservative code, class and length of pole. The pole roof and gain shall be brush coated with creosote conforming to AWPA PI or pentachlorophenal-petroleum solution conforming to AWPA P8 and P9. Each pole shall have a gain on the face of the pole $1 / 2$ inch deep by 4-1/2 inches in length with the center of gain 12 inches below the axis of roof cut. A $13 / 16$ inch diameter thru hole shall be drilled at the center and at right angles to the face of the gain. The top of each pole shall have a one-way roof cut sloping 30 degrees (120 degrees with pole axis) and the cut surface shall face at right angles to the pole face.

\section{ANCHORS}

Anchors shall conform to Hanford Standard D-4-1a. All anchor rods shall have double thimble eyes.

7. GUY STRAND

All guy strand shall be galvanized steel as specified on the drawings.

8. LINE HARDWARE

All line hardware for framing assemblies shall be galvanized and shall be as shown or noted on the drawings, or approved equals. 


\section{CROSSARMS}

Crossarms shall conform to EEI TD-90, and shall be of the size shown on Hanford Standards D-2-2a, D-2-2b, D-2-2c, and D-2-2d.

10. LINE CONDUCTORS

All line conductors shall be of the type, size and material as shown on the dxawings. Conductors of size No. 2 AWG and larger shall be stranded.

11. BOXES, ENCLOSURES AID DEVICES

Unless detailed, or specified otherwise on the drawings, boxes, enclosures and devices shall be as follows:

a. In the Hot Pilot Cells (Area 3) all boxes or enclosures shall be cast copper-free aluminum with threaded conduit hubs and gasketed covers. The enclosure shall be watertight.

b. In the Hot Metallurgical Cells (Area 4) all boxes or enclosures shall be cast metal with threaded conduit hubs and gasketed covers. The enclosures shall be watertight.

c. In the Cold Canyon Tank Pit (Area 1) all boxes or enclosures shall be Class I Group D explosion proof with a polyvinyl chloride, thermoplastic covering and stainless steel screws and fittings.

d. In the locations listed below all boxes or enclosires shall be vapor proof and cast metal or NEMA Type 12 with threaded conduit hubs and gasketed covers:

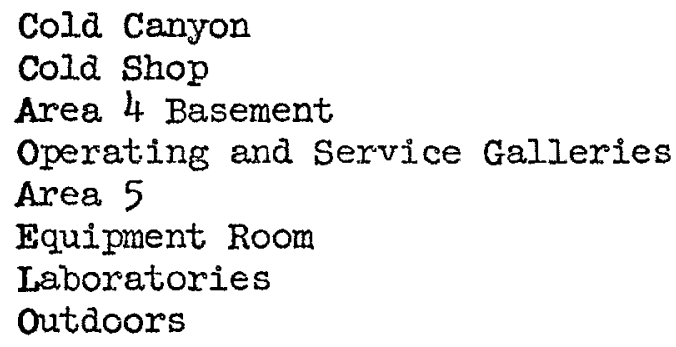

e. In Area 2 all boxes or enclosures shall be sheet metal or pressed steel. Plaster covers shall be used on switch, receptacle, or telephone boxes installed flush in plaster walls or ceilings. Where devices are shown back to back in a two-inch plaster wall, shallow two-gang covers shall be used with a double opening two-gang box and a two-gang plate with off-set duplex receptacle cutout.

All flush mounted boxes shall have stainless steel plates to fit the devices to be installed. 


\section{BOXES, ENCLOSURES AND DEVICES (Continued)}

f. Devices used in the areas specified above shall be made vapor proof or watertight, as required, by using cover plates to suit the device.

\section{RACEWAYS AIND FTTTINGS}

a. Rigid steel conduit shall be hot dipped galvanized, zine metalized, or sherardized conduit and shall meet the requirements of Federal specification WW-C-58Ic. An anti-friction finish shall be applied to the internal surfaces. Unless otherwise shown on the drawings, minimum size conduit shall be $3 / 4$ inch I.P.S.

In the Cold Canyon Tank Pit and Room 15 all conduits and fittings shall be coated with polyvinyl chloride.

b. Electric Metallic Tubing shall be hot dipped galvanized, zinc metalized, or sherardized with an internal surface finish of anti-friction lacquer and shall meet the requirements of Federal Specification WW-T-806b. Connectors and couplings shall be watertight. Indentor type fittings are not permitted. Unless specified otherwise on the drawings, the minimum size of EMI shall be $3 / 4$ inch; except, $1 / 2$ inch EMP may be usej for 120 volt receptacles and switches mounted in two-inch plaster walls.

c. Flexible conduit and fittings shall be liquid tight, Type UA. The liquid tight flexible conduit shall be jacketed with radiation resistart compounds such as Hypalon 40, Neoprene, Polyethylene, Scotch No. 27 tare, or approved equal.

d. All steel conduit fittings shall be galvanized. Threadless fittings shall not be used.

e. Rigid aluminum conduit in accordance with Federal Specification WW-C-540a may be used in all sizes $3 / 4$ inch and larger as a substitute for EMI or rigid steel conduit, except where embedded in concrete or another type is specified on the drawings or in this specification. An anti-friction finish shall be applied to the internal surfaces.

f. Only aluminum couplings and fittings shall be used with aluminum conduit.

g. Wireways or ducts and fittings shall be flangeless, of the size specified on the drawings, fitted with hinged covers and shall be General Electric "Hinged Cover Wireway," Square D Company "Lay-InDuct," Keystone "Lay-In-Wireway," or approved equal. 
12. RACEWAYS AND FITTINGS (Continued)

h. Auxiliary gutters shall be constructed of galvanized sheet steel. Removable covers shall be held in place by winged head captive fasteners not smaller than 1/4 inch diameter. Maximum length of any one cover shall be four feet. Maximum spacing of cover fasteners shall be 12 inches. Cover fasteners, coupling, and fittings shall not extend into the duct and shall not have sharp edges or points. Struts, spaced not more than four feet epart, shall be fixed across the open side in order to maintain rigidity.

i. Wireways, gutters, cable trays, or banks of conduit and equipment shail be supported on hangers, factory rade for the purpose, or on built up metal framing such as "Unistrut," "Kindorf," or approved equal.

j. Cable trays and fittings shall be of the size specified on the drawings and shall be ladder type with rungs slotted and spaced six inches on center unless specified otherwise. The sides of the ladder shall be a nominal three inches in height formed in channel or "zee" with $3 / 4$ inch legs. The rungs shall be rigidly attached to the channels. The channei and rungs shall be not less than 0.081 inch thick, high strength aluminum alloy. Channel connectors shall be 0.125 inch thick aluminum. Ladier and fittings shall be free of any sharp edges or projections. All bolts and nuts used for support and assembly shall be non-corrosive type and shall not project into the cable space except for large radius, $3 / 4$ inch minimum, bolt heads.

k. Interlocked armored cable terminating connectors shall be aluminum, watertight and with a grounding cable pad or connector. Accessories for bracket supporting or threaded hub connections shall be compatible with the termination. Connectors and accessories shall be sized to fit the armored cable.

\section{CONDUCTORS}

\subsection{GENERAL}

Wire and cable shall be a type specified herein. Size and number of conductors shall be as shown on the drawings and as specified herein. All wire and cable for use in the 324 Building shall be accompanied by manufacturer's certification as to compliance with the applicable specificaticn as listed under section 13.2 below and as to date of manufacture. All sirgle conductor insulated wire shall be rejected for installation unless readily identified by continuous, permanent marking to indicate type, voltage, wire size and manufacturer. 


\subsection{WIRE AND CABLE - 600 VOLT}

a. Synthetic rubber insulated cable with polychloroprene or thermoplastic jacket shall be used in sizes No. 1/O AWG and larger and shall conform to Hanford Standard Specification HWS-8003-S.

b. Wire and cable for use in the Hot Pilot Cells and the Hot Metallurgical Cells including the surrounding walls, unless specified otherwise on the drawings, shall be insulated with polyethylene as specified in Hanford Standard Specification HWS-8002-S.

c. Except in High Radiation Zones; Hanford Standard Specification HWS-8002-S, Type $60 \mathrm{c}$ wire shall ke used for branch circuits from lighting panels, fire alarm system circuits and annunciator circuits. All other wire and cable shall be Type $75 \mathrm{C}$, except that wire installed in the wiring channels of baseboard heater-units shall be Type AVA as listed by Underwriter's Laboratories.

d. The minimum wire size for lighting and power circuits shall be No. 12 AWG. Unless specified otherwise, wire sizes No. 8 and larger shall be stranded and No, 10 and smaller shall be solid, except that all control wire and equipment grounding conductors shall be stranded. All conductors shall be copper unless shown otherwise on the drawings.

e. Multiple conductor cables shall be as specified in Hanford Standard Specification HWS-8004-S.

\subsection{WIRE MARKERS}

Identification marking of individual conductors, where required by the drawings or this specification, shall be by imprinted tubular plastic wire markers as manufactured by the E.C.P. Corporation, 4726 superior Avenue, Clevelanc 3, Ohio, or an approved equal.

\subsection{CABIE - $5 \mathrm{KV}$ AND $15 \mathrm{KV}$}

Cable shall be sized in accordance with the drawings. The $5 \mathrm{KV}$ cable shall be unshielded and shall conform to Hanford Standard Specification HWS-8006-S. The $15 \mathrm{KV}$ cable shall be shielded and shall conform to Hanferd Standard Specification HWS-8006-S.

\subsection{ITIERIOCKFD ARMOR CABLE}

Armored cable shall conform to Hanford Standard Specification HWS-8007-S. All splicing and terminating fittings shall be compatible with the cable and according to the manufacturer's recommendations. 


\subsection{GALVANIZED GROUNDING CONDUCTOR}

All grounding conductors, buried in the earth or encased in concrete, shall be steel strand wire, Common Grade, with Class B zinc coating in accordance with ASTM A218. Size shall be as shown on the drawings.

14. SOLDERLESS CONNECTORS AND TERMINALS - 600 VOLTS AID LESS

Pressure type, solderless connectors and terminal lugs shall be used in wiring not exceeding 600 volts between conductors. Connectors with insulating caps or covers shall be UL approved for the voltage of the system in which they are used. Connectors shall be as specified below, or approved equals.

a. For Conductors No. 8 AWG and smaller

(1) Ideal Industries, Inc. - IdeaI set screw type

(2) Burndy Engineering Company - "Hydent"

(3) Minnesota Mining and Manufacturing Company - "Scotchlock"

(4) Thomas \& Betts Company - "STA-KON"

b. For Conductors No. 6 AWG and larger

(1) Burndy Engineering Company - Screw pressure connectors or "Hypress"

(2) Thomas \& Betts Company - "Lock-Tite" connectors

(3) General Electric Company - "Pressure" connectors

\section{PANELS, BRANCH CIRCUIT}

a. Branch circuit panels for $120 / 240$ volt, three wire, single-phase systems shall be heavy duty circuit breaker type. The panels shall comply with U.S. Federal Specification W-P-13la, Class C. Bolted-in circuit breakers shall be 100 ampere frame and thermal magnetic type. The number and rating of circuit breakers for each panel shall be as shown on the panel schedule. The breakers shall comply with NEMA Publication No. AB-I-1959. Circuit breakers marked "Spare" shall be furnished in the size marked. Blank covers shall be provided for circuit breakers marked "Future." The main buses shall be rated for 225 amperes with solderless lug terminals. Cabinets shall be flush or surface mounted as indicated on the drawings. Cabinets shall have hinged doors with lock-type latches. 


\section{PANELS, BRANCH CIRCUIT (Continued)}

b. Subpanels located in the Cold Canyon, Cold Shop, and Low Level Canyon shall be 8 circuit 120/240 volt single phase, three wire, in a raintight enclosure. One 50 ampere, double pole circuit breaker and six 20 ampere single pole circuit breakers shall be provided with a solid neutral insulated from ground. Circuit breakers for subpanels may be plug-in type and shall be in accordance with Federal specification W-P-I3la, Class AI or A2.

16. GENERAL PURPOSE TRANSFORMERS, DRY TYPE

General purpose, dry type transformers shall be single phase, 60 cycle, 480 volts primary with two 2-1/2\% taps above and two 2-1/2\% taps below normal $120 / 240$ volts secondary. The transformers shall meet all ASA, NEMA, and AIES standards for transformers and specialty transformers. The transformers shall be suitable for floor or wall mounting. The ambient temperature rat: shall be $40 \mathrm{c}$. The maximum operating temperatures, dimensions, and weignts listed below for transformers, shall not be exceeded:

$\begin{array}{lllll}\text { Rating } & \text { Temp. Oper. } & \text { Height } & \text { Wt. Max. } \\ 25 \text { KVA } & 130 \mathrm{C} \mathrm{Max.} & 25 \mathrm{In} . \text { Max. } & 310 \text { Ibs. } \\ 37.5 \text {-KVA } & 170 \mathrm{C} " & 28 \text { " " } & 345 " 1 \\ 50 \mathrm{KVA} & 220 \mathrm{C} \mathrm{"} & 31 \text { " " } & 460 "\end{array}$

\section{LIGHTING FIXTURES}

\subsection{FLUORESCENT TYPE}

a. Lighting fixtures shall be of the type, size and quality specified on the drawings and in this specification. Each fixture shall meet or exceed the specified standards including photometric data, components, construction and materials. All components and the fixtures shall beethe UL label or the RLM label. Unless otherwise specified, each fixturi shall be furnished with standard cool white lamps.

b. Each fluorescent lamp ballast shall be individually fused in the primary circuit, or each ballast shall be protected with its own builtin, non-resettable thermo switch. Each ballast shall be CBM certified and of the high power factor type. Ballasts shall be replaceable witiout removal of the fixture and shall be mounted in the channel with non-turn studs.

c. Unless otherwise specified, the minimum thickness sheet metal used for the fixtures shall be 0.032 inch for steel and 0.040 inch for alumirim 


\subsection{FLUORESCENT TYPE (Continued)}

d. Wiring from the outlet box to the fixture or continuous mounted fixtures shall be UL approved $\# 14$ fixture wire rated at $90 \mathrm{C}$ and 1000 volts.

e. Type A fixtures shall be two lamp, industrial type for 1.5 ampere, 96 inch lamps in accordance with Hanford Standard Specification HWS-6200-S-II 28-1.5 and shall have steel reflectors and louvers.

f. Type B fixtures shall be two lamp, industrial type for 800 milli-ampere, 96 inch lamps in accordance with Hanford Standard Specification HWS-8200-S-II 28-HO and shall have steel reflectors and louvers.

8. Type C fixtures shall be two lamp, industrial type for 430 milli-ampere, 48 inch lamps in accordance with Hanford Standard Specification HWS-8200-S-IL 24-RS and shall have steel reflectors and louvers.

h. Type $D$ fixtures shall be suitable for mounting in the angle formed between the ceiling and the wall. The mounting shall be by fixture stud to a flush-mounted wall outlet box, unless shown otherwise. There shall be two 40112 RS lamps in each fixture. An extruded acrylic plastic or low-brightness glass diffuser shall reduce the brightness to 800 lamberts as measured at a 75 degree angle to the vertical. The finish shall be baked-on, gray or white enamel or aluminum.

i. Type $\mathbf{E}$ fixtures shall be troffer lay-in type with drop-dished, matte white finish, heavy gauge acrylic plastic diffuser. The fixture shall fit into a space formed by inverted " $T$ " bars spaced one foot by four feet. There shall be three 40TI2 RS lamps in each fixture. The coefficient of utilization for each fixture shall not be less than 0.31 and 0.42 for Room Indexes of 0.8 and 1.5 respectively. Lamps shall be replaceable without the use of tools. The diffuser and frame shall have devices to prevent accidental separation (or dropping) from the fixture body. All hinges and latches shall be concealed. When fixtures are mounted in continuous rows, the separating end plates shail be removed to reduce shadows at the lamp ends. The maximum depth of the fixture body shall be seven and a half inches. The brightness at 45 degrees nadir shall not be more than 850 foot lamberts.

1. Type $F$ fixtures shall be the same as Type $E$; except they shall be designed for two 40TI2 RS lamps.

k. Type $G$ fixtures shall be weather-proof floodlights for 96 inch 1.5 ampere lamps. Lamp holaer and connection fittings shall be watertight. Neoprene boots shall seal the lamp end to the holder. The reflector shall be aluminum with white baked enamel or polished aluminum reflecting surface. The reflector shall be mounted to permit an aiming range of 360 degrees. The lamp ballasts shall be remotely mounted in weatterproof or NEMA 12 enclosures. Lamp holders shall not be sealed with pitch and shall be wired with polyethylene insulated wire. 


\subsection{FLUORESCENT TYPE (Continued)}

1. Type J fixtures shall be two lamp industrial type for 1.5 ampere 48 inch lamps in accordance with Hanford Standard Specification HWS-8200-S-IWL 24-1.5 with steel reflectors and without louvers.

m. Type $M$ fixture shall be a shallow surface mounting two foot square unit with $1 / 2$ inch plastic cube louver. The fixture shall have six 24 inch, 20 watt preheat type lamps. The frame of the fixture shall be opaque with white baked enamel or aluminum finish.

n. Type $Y$ fixtures shall be nominal two foot round recessed type with a matte white, domed acrylic plastic diffuser. The fixture shall have six 20 watt, 24 inch preheat lamps. The recessed portion of the fixture may be rectangular, but the plaster ring and diffuser frame shall be round. The frame hinges and latch sihall be concealed. The coefficient of utilization of light shall not be less than 0.39 with a room index of 1.25. Maximum fixture depth shall be nine inches.

\subsection{INCANDESCENT AND MERCURY VAPOR TYPE}

a. Type H fixtures shall be wall mounted, porcelsain, pull chain, lampholder with white opal glass half shade and ome 150 watt lamp.

b. Type $K$ fixtures shall be industrial type with ventilated porcelain enamel reflector for an $R 52$ lamp. The hood shall be a disconnecting type with shock absorbing mogul socket. The lamp used shall be 400 watt, mercury vapor, reflector type No. H33-IHDN/C, per ASA C78.1305. The ballast used for two Type $K$ fixtures shall be two lamp, voltage stabilizing type for a 460 volt primary.

c. Type $L$ fixtures shall be the same as Type $K$ ffixtures; except the lamp used shall be a 500 watt $R 52$ bulb.

d. Type $\mathbb{N}$ fixtures shall be flush mounted recesssed type for a 150 watt PAR 38 spot light. The lamp shall be adjustable to 30 degrees from the vertical and 360 degrees horizontal.

e. Type $P$ fixtures shall be outside type in accrordance with Hanford Standard D-6-85 with 150 watt lamp.

f. Type $R$ fixtures shall be industrial type RIM standard dome. The hood shall be a disconnecting type with shock abssorbing mogul socket. The lamp used shall be a 300 watt mogul base sillver coated bowl \#300/SBIF. 


\subsection{INCANDESCENT AND MERCURY VAPOR TYPE (Continued)}

g. Type SS fixtures shall be vapor tight cast metal with green globe and metal guard. The lamp shall be 100 watt, inside frosted. The fixture shall be pendant, box or wall mounted to suit the installation. See Hanford Standard M-2-18 for the position of lamp with respect to the safety shower.

h. Type V fixtires shall be vapor tight cast metal with clear globe and without guard. The lamp usec shall be 200 watt, inside frosted. The fixture shail be penjant or wail mounted in accordance with the installation.

i. Type $W$ fixtures shall be Class I Group $D$ explosion proof with a polyvinyl chloride covering. The fixtures shall be ceiling type with 30 degree angle refiector. The globe shall be clear. The lamp used shall be 200 watt, inside frosted. Crouse Hinds EVCX 2157, or approved equal.

j. Type $W$ fixtures with a "SS" subscript shall be the same as Type W; except lamps shail be 100 wati and the globe shall be green.

k. Type $X$ fixtures shail be surface mounted exit lights with six inch high red translucent letters on an opaque background. Each fixture shall have two medium base scckets ana two 25 watt lamps.

\subsection{CELI LIGHTING FIXTURE ASSEMBLY}

Cell lightirg fixture assemblies shall be in accordance with Drawing 15-3-20333 and these specifications. The position of the Base outlet Unit with respect to the Guice Bracket shall be identical for all assemblies to permit complete interchangeability of the lamp-hclder units. All exposed metel on the assemblies shall be copper-free aluminum or stainless steel. For fixtuses utilizing mercury vapor lamps, the remote mounted. ballasts shali be single-lamp power factor corrected, auto-transformer type with taps for 440 and 460 volts.

\section{AUTOMATIC EMERGENCY IIGHTING UNITS}

Automatic lighting units shall be self-contained cabinets including a nickel-calnium battery, full-wave rectifier charger, control relay, and with two 25 watt seales. bean head lamps. The battery capacity shall be at least 30 ampere hours at s ter-hour discharge rate to 1.1 volts per cell. The batiery shall be capable of supplying 9.5 amperes for ninety (90) minutes to a minimum end voltage of 1.1 volts per cell. The control relay shall automatically connect the lamps to the battery upon failure of the II5 volt supply voltage. The battery voltage shall be maintained by trickle charging and high rate charging either timed or automatic. Each 
18. AUTOMATIC EMERGENCY LIGHTING UNITSS (Continued)

unit shall be connected to the power supply with a three wire cord and twist lock, cord-grip, 15 amp, 125 volt grounding plug cap. Maximum overall height of unit shall be 18 inches.

\section{FABRICATED ASSEMBLIES}

Fabricated assemblies such as equipment control stations, relay panels, and terminal boxes shall be as detailed on the drawings utilizing the components specified, or approved equal.

Unless otherwise specified, the wire shall be size \#14 stranded type $75 \mathrm{C}$ per HWS-8002-S. Crimp type terminals to fit the connected device shall be used. Terminal blocks shall be Burndy-Crablok, or approved equal. Identification of wire shall be according to section 36.f, and device numbers shall be painted in the enclosure near the device. A light gray enamel finish shall be applied to inside and outside surfaces of the enclosure. Unless otherwise specified, the contactors and relays used shall be in accordance with NEMA Standards and shall have contacts rated according to size specified. The contacts shall be convertible from normally open to normally closed or vice versa.

20. MOTOR CONTROL CENTERS

a. The motor control centers shall be constructed in accordance with Hanford Standard Specification HWS-8000-S and the schedules shown on Drawings $\mathrm{H}-3-20317, \mathrm{H}-3-20343, \mathrm{H}-3-20344, \mathrm{H}-3-20345, \mathrm{H}-3-20346$ and H-3-20347; except circuit breakers and overload devices in motor starters shall be sized for the motors furmished with the equipment.

b. The wiring of magnetic starters shall be as shown in "Elementary Diagrams" on Drawings H-3-20348, H-3-20349 and H-3-20350. Terminal points shall be marked with the wire numbers shown on the diagrams.

\section{CATHODIC PROTECTION RECTIFIER}

The direct current power supply unit shall be suitable for outdoor mounting and rated 48 volts, 20 amperes output. The power supply shall be complete with enclosure, transformer, metallic rectifier, voltmeter, ammeter, tap switch for voltage variation, and thermal-magnetic circuit breaker for the alternating current input. The voltage shall be variable from 24 to 48 volts in a minimum of twenty steps. The enclosure shall be rain tight with a hinged cover, and shall be suitable for pole or wall mounting. The ambient temperature rating shall be $50 \mathrm{C}$. The power input shall be nominal 120 or 240 volt $A C$. 
a. Equipment and materials shall be designed, approved, furnished and installed in accordance with NBFU 72 and with this section of the specifications and shall form an integrated auxiliary fire alarm system. The equipment shall be designed and applied to function as an auxiliary system to an existing municipal type fire alarm system. The municipal system utilizes a Gamewell Company Type B Vitaguard Central station with a line current of 100 milliamperes.

b. The auxiliary system shall consist of a coded master box, a local energy supply and control panel, a supervisory panel, five separate fire detector circuits, an auxiliary non-coded box circuit, a sprinkler system detector circuit, and a twenty-four drop annunciator. The sprinkler system is defined in Division XIII of these specifications. Location of the equipment is shown on Drawings $\mathrm{H}-3-20324$ and $\mathrm{H}-3-20325$. Screw type wire terminal blocks shall be provided and identified in each component for all interconnection wiring.

c. The master box shall be of the non-interfering and successive coded type (code number is 2311) in a flush mounting cabinet. The master box shall be of the local energy type in accordance with NFPA 73 . The master box shall be able to transmit its coded signal to the central station through the closed metallic circuit or through the ground in event the closed circuit is broken. The master box shall contain the spring driven type signaling mechanism that is tripped either manually or from the auxiliary circuits, a manual signal key, telephone jacks, silent test feature, manual grounding devices, and disconnecting devices.

d. The local energy supply and control panel shall contain the equipment to rectify and supervise a power supply for the system and also contain an auxiliary battery of sufficient capacity to maintain the system for 24 hours after the normal power is cut off. The input power to the local energy supply and control panel shall be 115 volts, 60 cycle single phase. The local energy control panel shall contain devices to monitor ten (includes three spares) fire detector or auxiliary box circuits and to transmit the alarm signal to the master box as well as signal the annunciator. Supervisory and trouble alarm circuits shall be provided to shown open detector circuits, loss of power, open alarm transmission circuit and low battery voltage. The auxiliary battery shall be dry type. A battery test pushbutton and volt meter with a one ohm per volt battery loading shunt resistor shall be included. Ammeters or one ammeter with transfer switch shall be provided to measure current in all monitored circuits. A $10 \mathrm{amp}, 115$ volt $\mathrm{AC}, \mathrm{N} . \mathrm{C}$. contact shall be provided to open on true alarm only (future fan shut down). The locai energy supply and control cabinet shall be provided with a keyed lock and shall be wall mounted. 
e. The supervisory panel shall provide an audible and visual indication that an alarm is being transmitted. The visual indication shall continue until the master box is reset and restored to operable condition. The supervisory panel shall provide features for supervised tripping of the master box, local fire drill evacuation, bell circuit relaying and silencing, and trouble alarm with silence switch for the local energy panel. The supervisory panel shall be flush mounting type with stainless steel or brushed aluminum front panel.

f. The auxiliary boxes shall be of the non-coded type. They shall be of a distinctive appearance and finished in "signal red" color. All stations shall be surface mounted unless noted otherwise on the drawings. All auxiliary stations shall have D.P.D.T. contacts of the positive type. Mercury column type contacts are not acceptable.

g. Automatic fire detectors shall be approved for coverage of 625 square feet. In addition, they shall be fixed temperature, rate compensated to close contacts on temperature rise to $160 \mathrm{~F}$ or $225 \mathrm{~F}$ as specified. Contacts shall be approved for one ampere at 24 volts DC or 120 volts AC.

h. The annunciator shall have twenty-four drops which are operated by closing contacts. The annunciator shall be signal flag type or lamp type. If lamp type is used, a single button lamp test control shall. be provided. The annunciator shall have a lock-in feature on the drops and a button to reset when the alarm is removed. An engraved, laminated phenolic plate shall be mounted on the cover to provide a schedule of the alarmed zones with respect to the drop number. See Drawing H-3-20325 for the schedule. The annunciator box shall be flush mounted with key-locked door. Cover finish shall be aluminum.

i. As an option, the local energy supply and control panel, the supervisory panel and the annunciator may be combined into one dust-proof, flush mounted cabinet not greater than 32 wide $x 60$ high $x 6$ inches deep. Only annunciator and supervisory indicating lamps shall be visible on the combined cabinet cover. The cover shall be shop primed and finish painted with the wall. The combined cabinet shall be mounted in the north wall of room 103, which forms part of the electrical chase. Some rearrangement of the devices in the electrical chase (see H-3-2033I) will be required. The rearrangement shall meet the approval of the Commission.

j. Terminal boxes shall be provided where shown and as needed to consolidate wiring circuits. Screw or pressure type terminals with identifying numbers shall be provided. Box enclosures shall be NEMA Type 12 or approved equal.

k. Interconnection wiring in detector and auxiliary box stations shall be color coded and wired in a definite and consistent pattern similar to method shown in Figure 1 herein.

\section{MULTIPLE OUTLET ASSEMBLIES}

Multiple outlet assemblies shall be provided with receptacles of the voltage and rating called for on the drawings. The receptacles shall be integrated into a metallic surface raceway to form a UL approved system. 
WIRES "A,D,EE'H" SHALL CONNECT ONLY TO THE LAST FIRE DETE CTOR OR AUXILIATY BOX IN THE SERIES

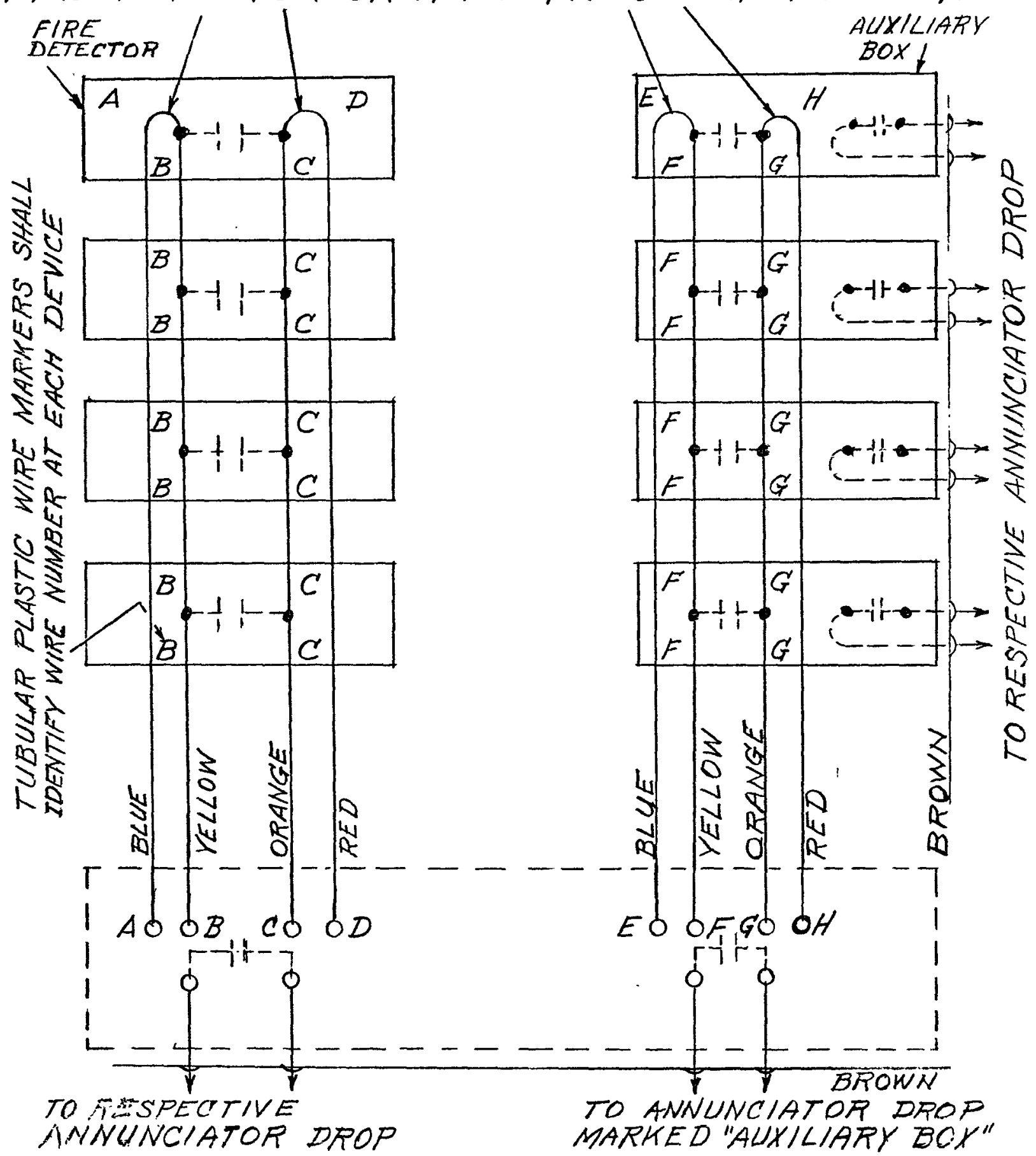

TYPICAL WIRING FOR FIRE DETECTOR AND AUXILIARY BOX CIRCUITS

$$
\text { FIG }{ }_{-255-} \quad H W S-5967
$$


24. BASEBOARD HEATERS

Electric baseboard heaters shall be sized in accordance with requirements shown on the drawings and shall have 230 volt, single phase, heating elements rated at 160 watts per lineal fobt.. Thermostats for baseboard heaters shall be 2 pole, 5000 watt capacity, line voltage thermostats mounted in matching sections to the heater units. Heater housings shall be finished in a neutral gray baked-on enamel. Dummy sections shall match heater sections.

\section{WORKMANSHIP}

\section{GENERAL}

a. All equipment, materials, conduits and boxes shall be installed as indicated on the drawings, and as specified herein.

b. The work shall conform to the requirements of the following listed codes except where specified otherwise on the drawings, or on the Hanford Standards or in this specification.

(1) National Fire Protection Association, NFPA 70, 72 \& 73. (2) National Electrical Safety Code (NESC)

(3) Washington State Rules for Installation of Electric Lines, 1954 and supplements thereto

Recommended methods and materials for installation of work described in the above codes, shall be mandatory unless specified otherwise herein, on the drawings, or on the referenced Hanford Standards.

c. All equipment, boxes, and conduit shall be securely bolted or fastened to structural members of the building or to metal supports attached to the structure. Fastening to metal wall or ceiling panels is not permitted. Supports attached to structural steel shall be clamped or welded.. Drilling of holes in structural steel will not be permitted except with specific written approval. Gunset studs or expansion anchors shall be used to fasten equipment to concrete structure.

d. All equipment, boxes, and conduit shall be located as per the dimensions on the drawings. When location dimensions are not shown, the equipment, boxes, and conduit shall be located approximately where shown and in relation to equipment served. Conduit raceways and boxes shall not be installed in positions that interfere with other services such as piping and ventilation. 
a. Poles shall be carefully unloaded and handled to avoid damage. They shall be hauled to location and not dragged over the ground or paved surfaces. Construction hooks, tongs, or other sharp tools shall not be used on treated portions of poles.

b. If poles are to be stored for longer than two weeks they shall be stacked carefully upon supports at least one foot above ground. Strength and spacing of supports and manner of piling shall be such that no noticeable distortion will be produced in poles so stored.

c. Preframed and treated poles shall be placed and oriented to comply with facing requirements of crossarms specified under section 27. Additional framing including gains, butt cuts and re-roofing that may be required shall be brush treated with cresote conforming to AWPA PI.

d. Holes shall be dug large enough to admit a tamping bar completely around the pole butt. Explosives shall not be used to excavate pole holes.

e. Backfill shall be made with material which can be solidly compacted by hand tamping in six inch lifts. Surplus earth shall be compacted around the pole in a cone one foot high. Where the backfill has settled, additional backfill shall be placed and tamped before completion of the work.

f. Poles shall be set plumb and in line, except that corners and strain points which are guyed shall have butts displaced to keep the tops in line.

\section{INSTALLING CROSSARMS}

Crossarms shall face each other on alternate spans on level construction. Crossarms shall be mounted at right angles to the axis of the poles. They shall be at right angles to the line on tangents, but shall bisect the angle where a line departs from a straight line but not exceeding 20 degrees. Double arms shall be used for dead ends, railroad and communication line crossings as required by the codes and as specified on drawings. Crossarms supporting wires of size No. O AWG or larger, shall be supported by ne-piece angle crossarm braces in place of the usual flat steel braces.

\section{INSTALLING HARDWARE}

Bolts shall be of sufficient length for full thread engagement of the nut, but shall not protrude through poles or arms in excess of two inches. 
28. INSTALLING HARDWARE - Continued

Bolt ends shall not be cut off. Square washers shall be used with each through-bolt and double-arming bolt.

29. INSTALLING INSULATORS

All primary insulators and strain insulators shall be wet process porcelain with brown glaze. Insulators for series street and fence lighting circuits shall have a white glaze. Pin insulators shall be tightened on the pin threads and top groove shall be adjusted parallel to the line. Insulator pins shall be steel. Holding nuts shall be made secure.

30. INSTALLING GUYS AND ANCHORS

a. Backfill around anchors shall be thoroughly compacted throughout the entire depth of the hole.

b. Where possible, down guys shall be run at an angle of 45 degrees. Guy rods set in earth shall be in line with the guy strand and shall have not less than 6 inches nor more than 12 inches of rod length exposed. Down guys shall be provided with steel guy guards in traffic areas.

c. Guys and anchors shall be installed according to Hanford Standards D-4-Ib, D-4-IC, D-4-Id, D-4-1e, D-4-1f.

31. STRINGING CONDUCTORS

a. Conductors shall be strung from reels. They shall not be dragged over the ground or permitted to lie where they may be damaged. Conductors shall be pulled through stringing sheaves, or over rounded surfaces on crossarms and racks. Conductors shall be inspected as they leave the reels and any weak or damaged section shall be cut out. Splices in conductors shall not be permitted in adjacent spans, dead end spans, or within four feet of a crossarm or support. Conductors shall be strung and tied to proper stringing tension in accordance with the recommendation of the manufacturer of the conductor.

b. All splices under tension shall be made mechanically and electrically secure by means of compression fittings. Self-gripping or automatic tension splicing sleeves shall not be used. Taps, jumpers, etc. shall be made with mechanical connectors. Dead ends on disc type insulators shall be by means of straight line clamps. 
31. STRINGING CONDUCTORS - Continued

c. Conductors shall be tied in the top groove of pin-type insulators when straight through or on the side against the strain at angle turns. Tie materials, sizes and lengths for various conductors and methods of tying shall be as shown or noted on the drawings.

d. Jumpers and taps shall be of kind and size equal to the smaller conductors of the tap line.

32. INSTALLING POLE LINE GROUNDS

Ground installations for aerial power distribution and telephone lines shall conform to Hanford Standard $D-3-3 a$ and $D-3-3 c$.

\section{INSTALLING BUIIDING GROUNDING SYSTEMS}

\subsection{UNDERGROUND ELECTRODES AND CONNECTIONS}

a. Grounding shall be by means of ground mat supplemented by driven ground electrodes in accordance with the drawings.

b. Ground rods shall be of galvanized steel not less than 5/8 inch in diameter by eight feet in length. They shall be driven at least six feet apart in areas where a number of rods are needed to reduce ground resistance. Resistance to ground shall be measured by the volt-ammeter or Wheatstone bridge methods or by commercial instruments designed for measuring ground resistance. Where the measured resistance to ground of a ground rod or rods exceeds 25 ohms, longer rods shall be driven if practical, or additional rods to a maximum of six shall be installed.

c. All grounding conductors installed in earth or concrete shall be Class B galvanized stranded steel. Grounding conductors exposed to the atmosphere shall be copper cable as shown on the drawings.

d. A ground bus, consisting of two 5/8 inch dia. galvanized steel cond.. uctors in parallel, bonded at intervals of not more than 40 feet, and buried at least 18 inches below grade, shall be placed around the periphery of the building, and connected to ground rods where shown on the drawings. The ground bus shall be connected to all metal water lines serving the building, as snow on the dzritirigs .

e. Buried grounding conductors shall be protected against all mechanical damage before and during backfill. Backfill material within one foot of the cable shall not contain rocks larger than two inches in diameter. 
33. INSTALLING BUIIDING GROUNDING SYSTEMS

\subsection{UNDERGROUIND ELECTRODES AND CONNECTIONS - Continued}

f. Splices and taps in galvanized steel grounding conductors that are to be buried in earth or concrete shall be made with cast copper joints, "Cadweld Process", or approved equal. The joint shall be completely covered with asphaltic paint and cotton tape for at least six inches each way from the joint.

g. Where it is necessary to join a copper conductor to a galvanized steel conductor or to any steel, the joint shall be made above the ground in a dry location.

h. The resistance of a ground conductor with joints or taps shall not be greater than the resistance of an equal length of continuous conductor without joints or taps.

\subsection{SYSTEM AND EQUIPMENT GROUNDING}

a. The neutral conductor of single-phase and three-phase, wyeconnected distribution systems shall be grounded at the transformer bank only.

b. Grounding methods shall be according to Hanford Standards, D-20-10, $\mathrm{D}-20-10 \mathrm{a}, \mathrm{D}-20-10 \mathrm{~b}, \mathrm{D}-20-10 \mathrm{C}$, and $\mathrm{D}-20-10 \mathrm{~d}$.

c. In this specification and on the drawings the term "equipment" shall be understood to mean all exposed metal parts of a wiring system including conduit, raceways, metal armor of cables, cabinets, switch boxes, outlet boxes, motor frames, motor controllers, panel boards, lighting fixtures, etc.

d. All metallic conduits, wixing channels, and the armor of armored cable shall be connected at each end to the grounding conductor or firmly attached at each end, with a good electrical contact, to a properly grounded connection box. Ground connections must be made to the grounding conductor at each box.

e. Portable electrical equipment shall be grounded by means of a separate green colored grounding conductor in the cord or cable equal in current-carrying capacity to the largest line conductor. The ground shall be completed through a separate grounding pole in the plug and receptacle.

\section{3 STATIC GROUNDING}

a. The steel columns of the building shall be thoroughly grounded to the ground grid as shown on the drawings. 


\section{INSTALLING BUILDING GROUNDING SYSTEMS}

\subsection{STATIC GROUNDING - Continued}

b. The installation of ground conductor risers, embedded in concrete, shall be in a manner to form an ever rising path from the ground mat to the highest termination. Also, bends of less than 8 inch radius shall not be permitted.

\section{RACEWAY AND TRAY INSTALIATION}

\subsection{INSTALLING STEEL CONDUITS}

a. Concealed conduits shall be run as directly and with as long bend radii as possible except in the cell walls (see Section 34.1 I). Exposed conduits shall be mun parallel to or at right angles with the lines of the building. Exposed horizontal runs of conduit shall be run not less than nine feet above the floor level unless shown otherwise on the drawings. All bends shall be made with standard conduit ells, field bends, or screw jointed conduit fittings.

b. All conduit field bends shall be made with standard bending devices and shall have an inner edge radius not less than specified in the National Electrical Code. All bends shall be free of dents or flattening and shall be capable of passing metal mandrels, with hemispherical ends, conforming to the following dimensions:

SIZE OF CONDUIT

$3 / 4$
$1-1 / 4$
$1-1 / 2$
2
$2-1 / 2$
3
4

\section{MANDREL DIAMETER} INCHES
0.62
0.78
1.03
1.20
1.55
1.85
2.30
3.00

\section{MANDREL IENGTH INCHES}
1.24
1.57
2.07
2.42
3.10
3.70
4.60
6.00

c. All conduit shall be cut square, reamed, have burrs removed, and shall be cleaned before the introduction of wires or cables. Immediately after installation, all conduit ends shall be plugged or capped with standard conduit accessories until wires are pulled.

d. Conduit joints shall be set up tight. Hangers and fastenings shall be secure and of a type appropriate in design and dimensions for the particular application. Maximum distance between supports shall be 7 feet for $3 / 4$ inch conduit or smaller and 10 feet for one inch conduit and larger. Runs shall be straight and plumb. Elbows, offsets and bends shall be uniform and symmetrical. 
34. RACEWAY AND TRAY INSTALLATION

\subsection{INSTALLING STEEL CONDUITS - Continued}

e. Couplings, connectors and fittings shall be approved types and shall be installed to provide a rigid mechanical assembly and positive electrical conductivity. Conduit and fittings shali be deburred.

f. Galvanized steel locknuts and bushings shall be used for attachment to enclosures unless a threaded hub is specified. In addition, ground wedges or bushings shall be installed as required by the grounding standards referenced in Section $33.2 \mathrm{~b}$. Threadless fittings are not permitted for rigid conduit unless specifically indicated on the drawings. Ericson type couplings shall be used where required. Running threads are not permitted.

g. One-hole malleable-iron pipe straps equipped with clamp-backs shall be used for fastening conduit to surfaces.

h. Conduits shall be run without moisture traps where possible. Where traps are unavoidable, a pull box or condulet with drilled hole shall be placed at each low point to provide a means of escape for moisture except where low point is embedded in concrete. Burrs snall be removed from driliec holes

i. The use of EMT is permitted only for exposed communication and lighting branch circuit wiring.

j. Flexible conduit in sections two feet long or less shall be used to make connections to motors and other equipment subject to vibration. Flexible conduit may also be used for other equipment where the use of rigid conduit is impractical. Galvanized flexible conduit and fittings shall be used in Area 2 (offices) only. Liquid-tight flexible conduit and fittings shall be used in all other locations. Where flexible conduit is extended from rigid aluminum conduit, a stainless steel or galvanized iron fitting shall be used at the flexible connection.

k. Conduit runs through outside walls and runs between Zones where an air pressure differential exists shall be sealed at both ends to prevent the flow of air through the conduit and consequent condensation of moisture on the inside surface of the conduit. Duct sealing compound such as "Volseal" or "Kerite" putty, or approved equal, shall be used for this purpose.

1. All conduit penetrations through walls, floors, or ceilings of the Hot Metallurgical Cells and Hot Pilot Cells shall be installed 
34. RACEWAY AND TRAY INSTALLATION

34.1 INSTALLITG STEEL CONDUITS - Continued

1. (Continued)

at the elevations and locations show on the drawings. Conduit terminations on the inside cell walls, etc. shall be flush stainless steel couplings welded to the metal liner. Unless otherwise dimensioned, conduits through a cell wall, floor or ceiling shall be offset a minimum of four size diameters. Each conduit end shall terminate perpendicular to the wall and shall have a straight length of one-third the wall thickness.

m. Conduit shall not be installed within six inches of piping operating at more than $140 \mathrm{~F}$ unless high temperature wire is to be used within the conduit.

n. Conduit runs shall be either all steel or all aluminum conduit except for flush coupled sleeves in walls or slabs. Aluminum conduit shall not be embedded in concrete.

o. Rigid steel conduit shall be used where embedded in masonry or concrete building construction. Under-slab runs of conduit shall be encased in concrete of 3 inches minimum thickness on all sides of the conduit.

p. All underground conduits shall be encased in concrete. The minimum depth below grade of underground ducts shall be 30 inches. The slope of the conduits shall be continuously toward the manhole or moisture trap. Conduit encasement shall conform to Hanford Standard D-15-1. Sumps shall conform to Hanford Standard D-15-20a. Pole risers shall conform to Hanford Standard D-15-22, D-15-20, D-15-20a, and $D-11-150$.

q. Type I asbestos-cement or fiber conduit shall be used only where encased in concrete.

$r$ All spare conduit runs shall have galvanized steel or copper pull wires installed.

s. Penetrations of conduits through walls, excluding cell walls, shall conform to details on $\mathrm{H}-3-20182$. 
34. RACEWAY AND TRAY INSTALIATION - Continued

34.2 INSTALLING ALUMINUM CONDUIT

a. Where rigid aluminum conduit is used, Sections 34.1 a, b, c, a, $e, f, g, h, m$ \& $n$ shall apply.

b. Aluminum conduit shall not be used for exposed runs in the Cask Handling and Truck Loak Areas or outdoors.

c. Where aluminum conduit enters a galvanized, sherardized, or painted steel cabinet, it shall be assembled the same as when using steel conduit. Where aluminum conduit joints with a steel conduit, an aluminum fitting shall be used.

Where a steel conduit sleeve with steel coupling is used through a masonry or concrete vall, aluminum conauit may be directly connected to the steel coupling without the use of aluminum fittings for continuation of the exposed aluminum conduit run except in wet locations, as described in Section $34.2 \mathrm{~b}$, where aluminum conduit shall not be used.

d. The installation instructions for aluminum conduit described below shall be followed when preparing and installing conduit. Also, installation instructions recommended by the conduit manufacturer shall be followed if not in conflict with the following:

(1) Sizes 1-1/4" and smaller shall be cut with a hacksaw. Sizes 1-1/2" and larger may be cut with a wheel-type cutter provided the conduit is carefully reamed after cutting.

(2) Conduit sizes 3/4" shall be bent with a I" EMT hand or \#I mechanical bender. Conduit sizes $I^{\prime \prime}$ shall be bent with a 1-1/4" hand or \#1 mechanical bender. Conduit sized $1+1 / 4^{\prime \prime}$ and larger shall be bent with \#2 mechanical or hydraulic bender.

(3) Sharp dies and cutting oil shall be used when threading conduit. Conduits shall be threaded to comply with d (5) below.

(4) When joints are made up tight, conduits shall not butt together. To assure a continuous ground path, the last three threads on each conduit connection shall be tight enough to make metal to meral contact to the coupling or fitting. 
34. RACEWAY AND TRAY INSTALIATION

\subsection{INSTALIING ALUMINUM CONDUIT - Continued}

d. (Cont.)

(5) All threaded joints skall be prepared by using an antiseize compound in the threads. Zinc dust and petroleum jelly in equal proportions by weight, heavy cup grease containing 25 per cent lubricating graphite, Crouse-Hinds STL type screw-thread lubricant, Burndy "Penetrox-A" oxide inhibiting compound, or approved equals are satisfactory.

\subsection{INSTALLING METAL RACEWAY OTHER THAN CONDUIT}

a. Cable trays, wireways, and metal duets shall be installed complete with the necessary fittings, connectors and parts according to the recomendations of the manufacturex.

b. All parts of cable trays, wireways, and metal ducts shall be assembled accurately and supported firmly. Supports shall be spaced not less than five feet apart, unless specifically shown otherwise on the drawings. Manufastured sections and fittings shall be used wherever possible. Field cuts or alterations shall be made in the manner prescribed by the manufacturer.

c. Cable trays, wireways, and metal ducts shall be free of all obstructions, burrs and sharp edges, and shall present a smooth surface for introduction of cable and wire.

d. Penetrations through walls or filoors by cable tray, wireways or metal ducts shall be sealed with a room temperature vulcanizing rubber compound. The wall or floor penetration shall be sized to give a close fit to the raceway in order to keep the amount of sealing compound to a minimum. Excess compound shall be trimmed off flush with the surface. Penetrations through metal walls shall be framed with closure strips similar to details for ducts on $\mathrm{H}-3-20182$.

\subsection{IDENTIFICATION OF CABLE TRAYS AND CCIDUIT}

a. All cable trays shall be identified with the tray number as shown on the drawings. The identification shall be black letters and numbers not less than $1-1 / 2$ " in height painted at intervals not exceeding 20 feet on a clearly visible side of the tray. 
34. RACEWAY AND TRAY INSTALIATION

34.4 IDENTIFICATION OF CABLE TRAYS AND CONDUIT - Continued

b. All embedded conduits shall be identified with the assigned conduit ( $P$ ) number or sleeve (SL) number by black characters not less than $1 / 2$ " in height painted on the wall where the conduit enters and emerges. Where conduits enter the back, sides, or tops of flush boxes, the conduit number shall be painted inside the box as close to the particular conduit as possible and visible upon inspection of the box. All surface conduit runs shall be identifiej at each end with $1 / 2^{\prime \prime}$ high black painted letters and numbers on the conduits.

35. INSTALIING BOXES, ENCLOSURES AND WIRTNG DEVICES

a. Junction and pull boxes shall be sized and installed in accordance with the National Electrical Code, unless other sizes are shown on the drawings. The type enclosure is specified in Section 11 herein.

b. Plpe plugs and knockout seals shall be installed in all unused openings of enclosures.

c. Outlet boxes for lighting fixtures shall be as shown in typical mounting on $\mathrm{H}-3-20318$.

d. All boxes shall be rigidly secured in position and plumb.

e. Outlet boxes, panels, or other electrical equipment must be 10cated at least 10 feet laterally from safety showers, unless such equipment is located eight feet or more above the floor.

f. Unless specified otherwise on the drawings, switches shall be mounted at four feet above the floor; receptacles shall be mounted at 18 inches above the floor in corridors or offices and four feet in all other locations, junction boxes shall not be lower than nine feet above the floor or six inches below the celling line.

8. All junction and pull boxes shall be identified with the proper number as shown on the drawings. The identification shall be painted black letters and numbers not less than one inch in helght on the box cover and on one side of the box for surface mounted boxes. For flush mounted boxes the cover shall be identified with one inch high black painted letters. The flush mounted boxes shall be identified with black painted letters 
35. INSTALLING BOXES, ENCLOSURES AND WIRING DEVICES - Continued

g. (Continued)

not less than $1 / 2$ " in height inside and on an unobstructed side or back portion of the box after the wiring installation is complete.

36. INSTALIING CONDUCTORS

a. All conduit runs shall be cleaned, dried, and blown free of all debris before any wire is pulled.

b. Wire smaller than No. 12 AWG shall not be installed unless specifically indicated on the drawings or in these specifications.

c. Cables installed in the trays shall not be bent, either during installation or in their permanent locations, to radii less than the cable manufacturer's corresponding minimum bending radii. Single conductor wires, when installed in trays, shall be tied together with cord to form feeder and control cables according to the wire run list. Knots shall be a maximum of 18 inches apart. Placing of cables in trays shall be in a manner to form straight parallel lines and to avoid crossing cables over each other.

d. All wires and cables carried in cable trays shall be tied to the tray at eight foot intervals or less with waxed linen cord or nylon tape. In all vertical cable tray runs, cables shall be tied to the trays at intervals of four feet maximum.

e. Circuit conductor color coding shall be:

Three Phase System
A Phase - Red
B Phase - Yellow
C Phase - Blue
Neutral - White
Ground - Green or bare

Single Phase System

Ungrounded - Black

Neutral - White

Ground - Green or bare

Paint or pressure-sensitive colored tape may be used to identify the conductors in lieu of colored insulation. Phase color coding shall be maintained for all main circuits, feeders, and subfeeders up to motor starters or branch circuit panels, but need not be carried to individual motors or branch circuits, except that the neutral and equipment ground conductors, where required, shall be identified throughout the system. 
36. INSTALLING CONDUCTORS - Continued

f. At each terminal point each individual conductor shall be identified according to the drawings by imprinted tubular plastic wire markers.

g. Only the cable manufacturer's recommended lubricant shall be used to decrease friction when pulling wire and cable through conduit.

h. Cables for the cathodic protection system shall be directly buried in earth to a minimum depth of eighteen inches. The cable shall be embedded in sand at least 3 inches above and below the cable with a 1 ; 8 creosoted board over the upper said layer.

37. SPLICES, TAPS, AND CABLE TERMINATIONS

a. Splices and taps in building wire shall be made with the solderless connectors as described under Section 14. Taps in receptacle or switch boxes shall be made with connectors and pig-tail wires to the device. Terminals on a device shall not be used as a wire tap.

b. Solderless connectors shall be used according to the Manufacturer's instructions. For connector types which require installation tools, the proper tool made especially for the connector shall be used. Connectors without insulating covers shall be taped.

c. Plastic insulating tape, made especially for electrical work, shall be used for all splices and taps on circuits up to 600 volts; except in Hot Cells where Scotch No. 27 tape, or approved equal, shall be used. The insulating tape shall be applied to a thickness at least equal to that of conductor insulation. Where a bolted splice or connection presents an irregular surface, an insulating putty, "Scotch-Fill", or approved equal, shall be applied to the joints before taping.

d. Manufacturer's instructions and directions shall be strictly adhered to for splices, stress cones and terminations for cables operating at over 600 volts to ground.

e. Armored cable shall be installed in cable trays as indicated on the drawings. Cables shall be strapped in place on all runs with a slope greater than 30 degrees from the horizontal. Insulation of joints and connectors shall be accoraing to the manufacturer's instructions and as detailed on the drawings.

38. INSTALLING EQUIPMENT FURNISHED BY THE COMMISSION

Wiring to equipment furnished by the Commission shall be furnished and installed in accordance with these specifications. Connections shall 


\section{INSTALLING EQUIPMENT FURNISHED BY THE COMMISSION - Continued}

be made according to insiructions with the equipment or to standard practice.

39. INSTALLING LIGHTING FIXTURES

a. Lighting fixtures shall be installed (according to the fixture schedule) complete with lamps. The heights of mounting shall be as specified on the drawings.

b. Fixtures shall be securely mounted by an approved fastening method. A fixture stud shall be used where fixtures weighing more than 15 pounds or fluorescent fixtures are hung from an outlet box. The box cover fastening screws. shall not be used to support these fixtures.

40. INSTALLING DISTRIBUTION AND BRANCH CIRCUTT PANELS

a. Panels shall be installed where shown on the drawings.

b. Circuits shall be connected to the disconnecting devices as shown on the drawings.

c. A panel directory shall be provided to identify the equipment served by each circuit.

41. INSTALIING MOTOR CONTROL CENTERS

a. Installation of motor control centers shall be according to the equipment manufacturer's instructions and as specified herein.

b. Motor control centers shall be plug welded to the angle sills, both front and back, a minimum of two places in each vertical section. Control centers shall be assembled and wired at shipping section breaks in accordance with manufacturer's instructions and all connections shall be checked and tightened. All covers and enclosures which have been removed for shipment or installation shall be replaced and bolted in place.

c. All wiring between adjacent control centers routed (as shown on the drawings) through the opening, either top or bottom, between the centers shall be installed and connected to the proper terminals as called for on the motor control center manufacturer's drawings.

d. Phase rotation shall be checked prior to making cable connections and shall be in accordance with the phase arrangement of the motor 
42.

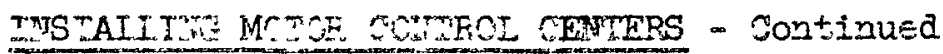

d. (constinued)

control :ex*er dxawinge, Cat ie ana bus conductors shall be son $c^{+} \in J$ Fitr phase sequen:e as follows when onserved from the front.
A Fhase
Fron:
Ieft
Top
B Drase
Gen:er.
Certer
CEnter
C Phas?
Fea:
Right
Bottom

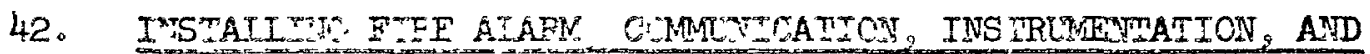
ETACUADTEXA AIAPM SISTDM

a. Elrept as spe:ifiei in this Ss sion, wing metrods for the fire alarm, somminiatcr. icstumentation and evacuation alarm systems are the same as for the cther electrisal systems covered in these spesifizarions.

b. All apil:es in alarm systems skall be made mechanically strong and soilexid. Single condiodcre in interior alarm systems shall not of smaller trar No. I4 AWG stranded.

c. Fire alam loc let.stor eirtuits shall be color coded and the same colors s2ail be mantingez trroughout each eircuit. (see Fig.I, Pg. 225)

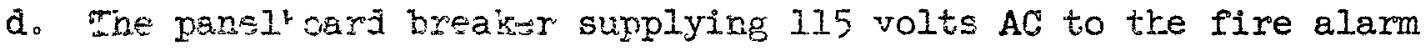
supsrisoty parsl, Homunicstion sysisem aud evecuetion alarm shall be fithed with a Elitable ghara requiring the rencval of a screw to opes the braarer, The supply breaker henlle shall be painted wit3 red examel.

e. Tht aukiliary fire alarm terminal boxes shall ke painted with red

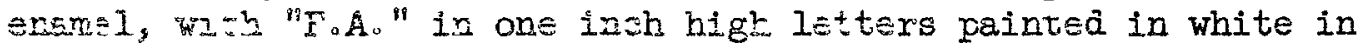
a prominent piace.

f. All fire alarm junztion axd pull box sovers shall be painted with red erarsel.

43. ISTAII TNC MOER CPERA EED DOORS

Wirlug to motcr operated dicrs shall be in accordance with the arawirgs, these specifications, and the acor manufacturer's instructions. Wirl:g to the limz: stitohes is not shown on the dravings but must be incluate in the znstellation. 


\section{INSPECTION AND TESTING}

\subsection{GENERAL}

a. All electrical equipment and wiring installed under these specifications shall be inspected and tested by the Contractor before any attempt is made to operate the equipment. Resistance, current and voltage measurements may be made as the work progresses. The Contractor shall maintain a systematic record by using a schedule or chart of all the tests and measurements. Space shall be provided to record readings, dates, and witnesses. All tests shall be witnessed by the Commission.

\subsection{MOTORS AIND GENERATORS}

a. All safety hazards to men and machinery shall be corrected.

3. Frames of motors and generators shall be checked for proper grounding.

c. Voltage, frequency and number of phases of power supply shall correspond with those required for the machine.

d. The electrical connections shall be checked for tightness and proper insulation.

e. Leads to motors and generators and power wiring shall be checked for proper numbering in accordance with drawings and specifications.

f. Bearlngs shall be inspected for proper lubrication.

g. The shaft end play and freedom of rotation shall be checked by hand where practical.

h. Belts shall be checked for the correct tension.

i. The voltage, current and speed under normal operating load shall be measured and recorded.

j. Supply and exhaust fans of the ventilation system shall be operated under normal load for a 6 hour heat run. The fan bearing temperatures and the motor bearing and winding temperatures shall be measured and recorded. Equipment shall be checked for any unusual noises or vibration.

\subsection{WIRING SYSTEMS}

a. All conduits and devices shall be checked for secure mounting and proper attachment.

$$
\text { -271- HWS }-5967
$$


44. INSPEGION AND TESTING

\subsection{WIFIME SYSTEMS - Gontinued}

b. Conarilets; junsticn boxes and raceways shall be checked for loose or misging covers.

c. Conduit connections shall be checked for tightness.

d. Panels shell be chesked for tightness of connections, filling of all open kncek-out holes, seclirity of mounting, mechanical dambe, identification of panel and circuits therein, cleanliness, and fuse size or overload protective device settings.

e. Cirouit numbers shall be checked for conformance with the arawings.

f. All wiring connections shall be cheoked for proper installation.

g. The proper color coding for all wire and cable shall be verified. All insulated ground conduetors shall be checked for green colored insulation identification.

h. Receptasles stall be chesked to assure proper functioning of devices, sorrest wiring and sorrect polarity of plugs and receptacles.

i. All wiring and sable, rated 600 volts or less, and used for services, power feeders, and brsnch circuits, shall be tested phase to phase and phase to ground with a 500 volt megger. The instrument manufacturer's instruction pamphlet, accompanying the instmment, will provide the detailed instructions for methods of conducting the tests. Any device not capable of withstanding the voltage and eurrent of a megger test (such as microphones, resoriding and indicating instruments, relays, and lamps) shall be disconsestad or by-passed before the test is made. To prevent damage to tire wiring under test and to the electrical devices left in plase ciuring the test, the maximum output of the megger to be used with eack elass of insulation shall be as follows:

\section{VOTWAEE OU PUT CF MEGGER}

100 and 250 volts

400 volts

500 volts
VOLTAGE RATING OF EQUIPMENT AND WIRTNC TO BE TESTED

Up to 100 volts

$T \in$ lephone cable

100 to 600 volts 
44.3 WIRTVIG STSTEMS - Continued

j. It is permissibie to test the entire system or any part of a system ineluding feeder cables, etc., provided the observed minimum insuiation resistance is equal to or greater than the values specified in Section 110-19 of the National Electrical Code for the smaliest size of wire included in the system or part under test. If such readings are low, the system must be sepsrated until the part causing the low reading is determined and corrected.

\subsection{IICHING SESFEMS}

a. An inspertion shall be made to determine that panel interiors ere ciean, wiring has been properly supported, breakers are of correct rating as shown on the drawings, and that circuit directories have been satisfactorily filled out.

b. An inspection shs,ll be made to insure that all lighting fixtures are properly mounted, equipped with correct size of lamps or tubes, are ciean and in satisfactory operating condition.

c. All fixtures, receptacles, anä appliances shall be checked for correct circuiting and switching as per the drawings.

d. It shall be demonstrated that each fixture, other than fluorescent, in the Hot Metailurgical Cells and the Hot Pilot Cells can be removed from and replaced on the fixture base using only a hook and the fixture bail. It shall be further demonstrated that fixivres are interchangeable between bases.

\subsection{MOTOR CONTROT CENTERS AND STARTERS}

a. Each cublcie shall be checked for proper nameplate identification.

b. Equipment and devices ir contrcl center cubicles shall be checked with the drawings and schedules to assure that they are correctly mounted and wired, and installed in the correct compartment. The size and rating of breakers, fuses and overload heaters shall be verified.

c. Wire tag numiers, terminal strip markings and wiring shall be checked with the drawings. Wiring shall be checked for standard color coting of phases. 


\section{INSPECTION AND TESTING}

\subsection{MOTOR CONTROL CENTERS AND STARTERS - Continued}

d. The instaliation of arc-confining baffles or barriers between compartments and devices where provided in control centers shall be checked.

e. All vertical and horizontal bus supports and insulator bolts shall be checked for tightness. All connections, bus to bus, bus to lugs, and bus to stabs shall be inspected to determine that they are silvered, tight, and corrosion free. Buses shall be checked for proper bus phase arrangement as called for in these specifications.

f. Each unit assembly in the control center shall be removed and checked for horizontal and vertical alignment of units and guides, and alignment of stabs with buses. There shall be no tendency to twist or turn out of position or fit loosely. The unit stabs shall make contact automatically with insertion of unit and disconnest automatically with removal of unit.

g. Compartment door fit and door handle interlocking features shall be checked to assure that door cannot be opened when unit it houses is energized. Operating handle linkages shall have a minimum of slack or play. Handle shall be lockable in either the "on" or "off" position. The switch or breaker position marker shall be checked for correct indication, i.e., breaker or switch is "open" or "closed" or breaker is "tripped" as marker indicates.

h. All breaker, switch, and starter mechanisms shall be checked to see that nuts and bolts are in place and tight, that no pins or keys have worked out of place and that all cotter pins have sufficient spread. Mechanism rods and moving parts shall not bind and shall be in proper working orōer.

i. Motor starters shall be operated several times to check for bindfree operation of moving parts, proper contact area and pressure of main and auxiliary contacts, and correct operating coil voltage.

j. Control transformers shall be checked for proper voltage ratio. Fuses for the transformers shall be removed and checked for correct size and condition. All connections and mounting bolts shall be tight. 
44. INSPECTION AND TESTING

44.5 MOTOR CONTROL CENTERS AND STARTERS - Continued

k. Pilot lights shall be checked to assure proper indication of motor operation. Push buttons shall be checked for connections and operability.

1. Insulation tests shall be made before energizing the control center by meggering all buses, intemal cabling, breakers and starters, phase to phase and phase to ground.

44.6 TRANSFORMERS

a. The condition of high and low voltage bushings shall be .checked for freedom from damage and cleanliness.

b. The condition of high voltage stress cone connections and low voltage bus connections shall be checked.

c. Oil gauges and thermometers shall be checked for damage, tightness, and proper indication.

d. The oil level shall be checked and corrected to temperature of oil.

e. The case and fittings shall be inspected for oil leaks.

f. The breather shall be checked for obstructions.

g. The relief diaphram shall be checked for operation.

h. The tank ground shall be checked for continuity and tightness of connections.

\subsection{SWITCHGEAR}

a. The switchgear, auxiliarles and conduits shall be checked for workmanship and general appearance. Any external factors such as moisture, chemicals, dust and oil that are detrimental to the switchgear shall be noted and corrected.

b. All breakers and compartments shall be checked for identification according to the drawings.

c. Switchgear shall be checked for missing covers, loose or missing parts, dirt on relays, meters, or other devices. Doors and locks shall be checked for proper fit. 
44. INSPECTION AND TESTTING

44.7 SWIICHGEAR - Continued

d. The overcurrent tripping devices and the trip latches shall be inspected for freedom of movement.

e. The operating voltage shall be adequate for correct operation of all breakers.

f. All breakers shall be "racked out" from the enclosures and checked for proper functioning of the mechanism. All readily accessible parts shall be checked for proper insulation from live parts of . the breaker. The mechanical interlccks shall be checked for positive trip before a breaker can be moved from the correct position, and when approaching the connect position from the disconnect position.

g. The door shall be checked to insure that it cammot be opened when the breaker is closed without tripping the breaker as specified. Check provisions for locking the breaker in the trip position and locking of the lift mechanism or door.

h. All buses, incoming lines, feeders, and tie conmectors shall be checked for phase sequence, identity and proper color coding.

i. Each control switch shall be checked for operatiion and provision for locking in the trip position. Operation ofi red and green lights shall be checked for correct operation in the respective positions of the breakers.

j. Insulation tests shall be made before energizimg the switchgear by meggering all busses, internal cabling and breakers, phase to phase and phase to ground.

k. All overcurrent, undervoltage and timing relayss shall be:

(1) Tested and adjusted according to the Manuffacturer's instructions by the Commission. The Contractor shall remove and replace the relays in the switchgear for these tests.

(2) The Contractor shall notify the Commissiom three working days prior to the time the relays are to be tested. Completion of the test and adjustment of relays will nott constitute acceptance of the switchgear.

1. All electrically operated circuit breakers shalll be:

(1) Closed and opened at least three times usijing the respective control switch.

(2) Tripped three times by simulating overcurrent conditions.

(3) Tripped (bus tie) and closed (emergency liine) three times by simulating loss of voltage on the normal ibus. 
44. INSPECTION AND TESTING

44.7 SWITCHGEAR - Continued

m. All manually operated circuit breakers shall be closed and opened three times. The overcurrent settings shall be checked for the correct settings.

n. Voltmeters and ammeters shall be checked for proper indication on each phase by operating transfer switch.

o. Key interlocked breakers and primary disconnects shall be checked for operation of the Iock system. The number of keys specified for each interlock system shall be checlied.

p. Painted surfaces shall be checked for scratches.

\subsection{FIRE AIARM}

a. Check that each fire detector loop circuit is color coded and that the same colors are maintained throughout each individual circuit.

b. The supervisory current of each loop circuit and master box trip circuit shall be checked.

c. The fire alarm test switch shall be operated to determine that the alarm sounds.

d. All circuits shall be checked for grounds.

e. Supervised circuits shall be checked for open line operation.

f. Each master box shall be operated and checked for non-interference operation and broken-line operation. Proper timing and coding, as determined by the Cormission, shall be checked.

g. Each auxiliary box shall be checked for operation of master box.

h. Each fire detector head shall be thermally checked for operation of master box.

i. All sprinkler systems shall be checked for proper operation of master box.

j. The alarm function for loss of $\mathrm{AC}$ power supply and low battery voltage shall be checked.

k. A.l annunciator signals for detectors, auxiliary boxes and flow switches shall be checked for proper operation and identification. 


\section{DIVISION XVIII}

SUBSTATION AND SWITCHGEAR

\section{GENERRAL}

\section{1. $\quad$ SCOPE}

This division covers two outdoor-mounted transformers with secondary bus duct and connections to indoor, metal clad switchgear for power supply to the Fuels Recycle Pilot Plait, Building 324. Arrangement of the equipment is shown on drawing H-3-20292.

\section{SUBMISSION OF DRAWINGS AND INFORMATION}

a. The Contractor shall furnish to the Commission for approval, elementary drawings, outline, wiring and connection diagrams for all equipment furnished under this division of the specifications. In adition, time-current characteristic

curves of all fuses and other overcurrent devices shall be plotted on $\mathrm{K} \& \mathrm{E} 336 \mathrm{E}$ graph paper and furnished to the Cormission prior to purchase of such equipment. Maintenance, installation and oper. ating instructions together with suggested spare parts lists for the equipment actually furnished shall be supplied to the Commission at the time the equipment is shipped from the factory. Drawings and information shall be furnished in conformance with the requirements stated in the Special Conditions.

b. The Contractor shall furnish to the Commission a set of 8 " $\times 10^{\prime \prime}$ (minimum size) photographs of the transformer core and windings, taken at the factory during assembly. The photographs shall be taken from a sufficient number of points to show details of construction, connection arrargements and location of internal parts. Photographs shall be made just prior to mounting core and windings in the tank. Each photograph shall be labeled with the transformer KVA rating, voltage rating and serial number. Photographs shall accompany the certified test reports specified in Section 5 herein.

3. REFERENCED STANDARDS AND SPECIFICATIONS

The standards and specifications listed below form a part of this specification to the extent indicated by subsequent references. 


\subsection{AMERICAN STANDARDS ASSOCIATION (ASA)}

ASA C57.12.00-1958 Requirements, Terminology and Test Code for Distribution, Power and Regulating Transformers - General.

ASA C57.12.00-1958 Transformers, 67,000 Volts and Below, 501 Through 10,000 KVA, 3 Phase.

ASA C76.1-1943 Apparatus Bushings and Test Code for Apparatus Bushings.

ASA C76.1a-1958 Outdoor Apparatus Bushings.

3.2 FEDERAL SPECIFICATIONS

TT-E-489c Enamel, Gloss, Alkyd, Interior and Exterior

3.3 FEDERAL STANDARDS

No. $595 \quad$ Colors

3.4 HANFORD STANDARD SPECIFTCATIONS

HWS-8001-S, Rev. I Metal Enclosed Switchgear, 600 Volts.

HWS-8011-S Electrical Insulating 0 il.

\section{MATERIAIS}

\section{TRANSFORMERS}

4.1 RATINGS

a. The $1680 \mathrm{KVA}$ oil-filled transformer rating shall be as follows:
(1) Temperature Rise over $40 \mathrm{C}$ -
65 C by resistance
(2) Oil Air Rating -
(3) Forced Air Oil Rating -
$80 \mathrm{C}$ by Hot Spot
$1680 \mathrm{kVA}$
(4) High Voltage Winding, Delta -
1932 KVA
(5) Low Voltage Winding Wye -
(6) Number of Phases -
(7) Frequency -
13,800 Volts 480 Volts
3
60 Cycles 


\subsection{RATINGS (continued)}

b. The $225 \mathrm{KVA}$ oil filled transformer rating shall be as follows:

(I) Temperature Rise over $40 \mathrm{C}$ -

(2) Oil Air Rating -

(3) Number of Phases -

(4) Frequency -

(5) High Voltage Winding, Delta -

(6) Low Voltage Winding Wye -
$55 \mathrm{C}$ by resistance

$65 \mathrm{C}$ by Hot Spot $225 \mathrm{KVA}$

3

60 Cycles

2400 volts

480 volts

4.2 TYPE

Both transformers shall be standard oil preservation type in sealed tank in accordance with ASA C57.12.10, section 179.800 .

\subsection{MANUAL TAP CHAINGERS}

The transformers shall be provided with four 2-I/2 per cent rated KVA taps in the high voltage winding; two above and two below rated primary voltage. The manual tap changers shall be externally operated; shall have five (5) positions; and shall be suitable for operation only when the transformer is de-energized.

4.4 INCOMING LINE SECTION

Each incoming line section shall be designed in accordance with industry standards and shall be equipped as described below.

a. The $1680 \mathrm{KVA}$ transformer shall have an unfused air=interrupter switch with stored energy mechanism. The switch shall be 2-position (openclose) rated $15 \mathrm{kV}, 600$ amperes and key interlosked with low voltage breakers.

b. The $225 \mathrm{KVA}$ transformer shall have an unfused, air-interrupter switch with stored energy mechanism. The switch shall be 2-position (openclose) rated $5 \mathrm{KV}, 600$ amperes and key interlocked with low voltage breakers.

\subsection{IOW VOLTAGE TRANSITION SECTION}

a. The low voltage bushing and transition section of the 1680 KVA transformer shall be properly coordinated for field connection to the 3000 ampere bus duct. The low voltage neutral bushing shall be brought out and equipment provided for field connection to the transformer ground block and the switchgear ground bus. 


\subsection{IOW VOLTAGE TRANSITION SECTION (Continued)}

b. The low voltage bushings and transition section of the 225 KVA transformer shall be properly coordinated for conduit and cable connection from below. The neutral bushing shall be brought out and terminals provided for field connection to transformer ground block and a ground cable connection for run to the switchgear.

\subsection{MAINIENANCE DEVICES AND ACCESSORIES}

a. The following devices shall be provided as a part of each transformer:
(1) Ground pads
(2) Lifting lugs for lifting complete transformer
(3) Jacking bosses
(4) Towing attachments
(5) Pressure-vacuum gauge
(6) Diagramatic nameplate
(7) Drain valve
(8) Tap-filler valve
(9) Magnetic liquid level gauge

b. In addition to the above, the 1680 KVA transformer shall have the following:

(1) Forced air cooling fans with automatic temperature control by hottest spot indicator-relay with temperature indicator and three sequence contacts.

(2) Fan control cabinet.

\subsection{TRANSFORMER CONSTRUCTION}

a. The transformer tanks shall conform to the requirements of ASA C57. 12.10, Section 17.900 except that the tank finish shall match color No. 16329 from Federal standard 595.

b. A manhole shall be provided in the cover, above the oil level of the $1680 \mathrm{KVA}$ transformer and if circular, shall be a minimum of 18 inches in diameter; and if rectangular or oval, shall have minimum dimensions of 12 inches by 18 inches. The 225 KVA transformer shall have covered handholes as specified in ASA C57.12.10, Section 17.930.

c. The transformer tanks shall be equipped with the necessary radiators to meet the ratings specified. The radiators shall be supported from the transformer tank. 


\subsection{TRANSFORMER CONSTRUCTION (Continued)}

d. All meters, instruments, relays, and indicators shall be located $\mathrm{cn}$ the exterior of the transformer tanks. Any connections to wiring and/or devices located on the interior of the transformer tank shall be sealed, gasketed, and ctherwise arranged to prevent leakage of oil outward or air and moisture inward.

e. The 1680 KVA transformer shall have weatherproof cabinets with removable covers or hinged doors and these cabinets shall be welded to the exterior of the tank or mounted on brackets welded to the tank. The cabinets shall accomodate terminal blocks for wiring to external locations and controls and equipment required for the transformer. All of the cabinets shall have removable drilling plates and screened drip-proof breathers located in the bottom of the cabinets. All cabinets shall be completely supported by the transformer tank only ard shall be located near the transformer base. The terminal blocks ir the cabinets shall conform to the requirements of ASA C57.12.10, SEction $17 \mathrm{a} .639$.

f. Tank grounding pads shall conform to the requirements of ASA C57.12.10, Section 17.990. In additicn, clamp type, solderless terminals shall be bolted to the pads. The clamps shall be sized for 250 to 500 MCM stranded copper.

g. The transformers shall have a temperature instrument to measure and indicate the transformer winding "hctspot" temperature. The indicator dial shall not be smaller than, nor have a temperature range of less than that specified for the top oil thermometer. The temperature instrument for the $1680 \mathrm{KVA}$ trarsformer shall have not less than three, electrically separate, SPDT, self resetting switches with one normally open and one normally closed contact on each switch. The switch operation shall be as follows:

(1) Number 1 switch operate on rising temperature at $80 \mathrm{C}$ and reset at not less than $75 \mathrm{C}$ for decreasing temperature.

(2) Number 2 switch operate on rising temperature at $95 \mathrm{C}$ and reset. at not less than $85 \mathrm{C}$ for decreasing temperature.

(3) Number 3 switch operate on rising temperature at $105 \mathrm{C}$ and reset at not less than $95 \mathrm{C}$ for decreasing temperature.

The No. I switch contacts shall be rated for, and wired to control, the transformer cooling fans. The No. 2 and No. 3 switch contacts shall be wired to terminal blocks and reserved for future usage. All switches shall be independertly adjustable with the range plus or mirus $10 \mathrm{C}$ of the rising temperature operation point. 


\subsection{TRANSFORMER CONSTRUCTION (Continued)}

h. Transformer drain and filter valves shall be double disc gate type conforming to the requirements of the ASA C57.12.10, Section 17.660.

i. The liquid level gauge shall conform to the requirements of ASA C57. 12.10, Section 17.620 .

j. The thermometer for measuring the top oil temperature shall conform to the requirements of ASA C57.12.10, section 17.630. The thermometer shall show a red band on the dial above the maximum safe operating temperature level. The gauge shall have a self-resetting, high temperature, alarm contact, adjustable within the range of $65 \mathrm{C}$ to $100 \mathrm{C}$. The guage shall be adjusted at tine factory to close the alarm contact at $80 \mathrm{C}$.

k. The tap-changers shall conform to the requirements of ASA C57.12.I0, Section 17.610 .

1. Transformer cooling fans and controls, for the $1680 \mathrm{KVA}$ transformer, shall conform to the requirements of ASA C57.12.10, Section 17a.640, and shall be 240 volt, single phase.

m. Wiring and piping for the accessories ard parts of the transformers shall be provided in place. This requirement shall include all connections between electrical features and the wiring cabinet terminal blocks, for connection to external wiring.

\subsection{CORE AND WINDINGS}

a. The core of the transformers shall be made form non-aging, high permeability sheet steel in the form of stacked, thin laminations. The method of cutting and finishing the core laminations shall eliminate all burrs and irregularities on the pieces. The laminations shall be annealed and both sides of each piece shall be insulated with a heat resistant enamel.

b. The high and low voltage windings shall be separated by insulation barriers. The core and all non-current carrying metal parts shall be separated from the windings by insulation barriers. The assembly of the windings, barriers, and cores shall provide duct passages which will expose the transformer virdings to direct contact with the circulating cooling oil. The oil duct shape and arrangement shall be provided and maintained by the use of insulating materials formed into spacers which are secured into place by ties and/or cement not affected by continuous immersion in the insulating oil used. 


\subsection{CORE AND WINDINGS (Continued)}

c. The windings shall be braced and fastened into place so there will not be any movement during normal or abnormal operating conditions including fault current. Where redges and blocks are used, they shall be held in place by means of set screws or metallic fasteners.

d. The windings shall withstand impulse, induced and dielectric test voltage in accordance with ASA C57.12.00, Section 6.200.

e. All winding connections shall be brazea and/or clamp type solderless. Solder connections shall not be used.

f. The windings shall be fully insulated and rated for operation on an ungrounded system.

4.9 BUSHINGS

a. All bushings shall be furnished installed and ready for service.

b. All bushings shall conform to and be tested in accordance with ASA C76.1, C76.1a and C57.12, section 7.100.

c. All porcelain parts shall be glazed, uniform colored, wet-process porcelain with galvanized iror or steel mounting flanges.

d. The transformer windings shall be connected to the bushings by solderless methods which can be disconnected and reconnected without the use of destructive methods such as the breaking of welded or brazed joints. Each bushing shall be equipped with double clamp type terminal connectors.

\subsection{TRANSFORMER OII}

Transformer insulating oil shall be in accordance with Hanford Standard Specification HWS-8011-S.

\section{II NAMEPLATES}

Transformer nameplates shall conform to the requirements specified in ASA C57.12.00, Section 7.750 .

\subsection{PAINTING}

a. All metal surfaces shall be thoroughly cleaned to remove scale, embedded and extraneous materials and weld spatter prior to painting. The exterior surfaces shall be given a minimum of one coat of metal-protective primer and two coats of alkyd, gloss enamel, conforming to 


\subsection{PAINIING (Continued)}

Federal Specification TT-E-489c, Type II. Color shall be No. 16329 per Federal Standard 595.

b. Before the transformer is painted, all finish work, plated metal, gasket surfaces, bearing surfaces, and the interior areas of yipe connections shall be masked with strippable materials. The masking shall be removed prior to placement of the transformer in service. All edges, corners, and other prominent painted features likely to be scuffed, scratched, or otherwise damaged shall be protected during assembly, testing, shipment and installation.

\subsection{GASKEIS}

a. All gaskets shall be neoprene or other non-aging, tough, oil, acid, alkali and weather resistant synthetic materials.

b. An additional set of gaskets, with cement, identified by markings and installation instructions for use to replace temporary cover plates and barriers used during shipment shall be furnished to the Commission. Gasket cement, where required, shall be furnished packased with location and usage instructions.

c. When gaskets cannot be furnished as precut, one piece units, the scarf joints shall be prepared and match marked before shipment. The pieces for any one gasket shall be tied or packaged as a single bundle and identified by a durable label.

\section{CERTIFIED TESTS}

a. The tests listed below shall be applied to the transformers ard tap changer and shall be performed at the factory. Recorded data and/or oscillogram shall be certified as correct and sent to the Comission in 10 copies.

b. All tests shall be performed in accordance with ASA C57.12.90.

c. The transformer shall receive the following tests:

(1) Resistance measurements of all windings on the rated voltage tap connection and also at the tap extremes.

(2) Ratio tests on the rated voltage connection and on each tap connection.

(3) Polarity and phase-relation tests on the rated voltage connection. 
5. CERTIFTED TESTS (Continued)

c. (Continued)

(4) No-load loss at 90 per cent, 100 per cent, and 110 per cent of rated voltage.

(5) Exciting current at 85 per cent, 100 per cent and 115 per cent of rated voltage.

(6) Impedance and load loss at rated current on the rated voltage connection and also or the tap extremes.

(7) Regulation test for self cooled and fan cooled ratings at 80 per cent, 90 per cent, and unity power factors.

(8) Temperature rise tests at self-cooled and forced-air=cooled nameplate KVA ratings. The winding and top oil temperature readings indicated by the meters furnished with the transformer shall be reported in the certified test report together with simultaneous readings indicated by the factory test instruments.

(9) Applied potential test.

(10) Induced potential test.

(II) Impulse test.

(12) Voltage regulation at unity and 80 per cent lagging power factor for self-cooled and forced-air-cooled ratings.

d. An efficiency curve shall be calculated from no lead to full forcedair-cooled load for the $1680 \mathrm{KVA}$ transformer and no load to full self-cooled load on the $225 \mathrm{KVA}$ transformer. These measurements shall be made at rated voltage on the rated voltage connection.

e. The $1680 \mathrm{KVA}$ transformer windings shall be given the following tests:

(1) Capacitance between $13.8 \mathrm{kV}$ windings and ground.

(2) Capacitance between $13.8 \mathrm{KV}$ and 480 volt windings.

f. The certified test report assembly shall contain the following items:

(1) Results of wiring and equipment dielectric tests on control devices made in compliance with NEC and NEMA instructions. 
5. CERTIFIED TESTS (Continued)

f. Continued

(2) Photos of core and windings made prior to placing in tank for shipment.

(3) Certification that the transformer and parts will be free from corona damage for all voltages less than 115 per cent of the highest rated tap voltage.

6. FIEID TESTS

a. During the construction period a program of tests shall be made tc determine whether the equipment specified in the division may be safely energized. The test program will go beyond the usual minimum checks for alignment, clearances, air gaps and wiring errors. The Commission will furnish the test equipment and the operators. The Contractor shall furnish the labor required to take oil samples, move equipment, make connections, remove connections and related activities in connection with the tests named.

b. The test program shall include the following tests:

(1) Oil sample

(2) Voltage ratio

(3) Polarity

(4) Megger

(5) Doble power factor tests

(6) Operation check of fans, tap changer, etc.

(7) Winding resistance test on all tap settings.

c. Each transformer will be inspected and examined for shipping damage and unsatisfactory condition by the Commission prior to any field testing. The results of the inspection and/or field test data which appear to indicate deficiencies will be referred to the Contractor for correction.

a. The Contractor shall notify the Commission 3 working days prior to the time the equipment is ready to be tested. Completion of the test prcgram specified herein vill not constitute acceptance of the equipment by the Commission but shall be completed prior to such acceptance.

7. LOW VOLTAGE FEEDER BUS WAY

a. The feeder busway between the 1680 KVA transformer and switchgear sha1] be in accordance with the construction drawings and shall be furnishe with all necessary components for a complete system. 


\section{LOW VOLTAGE FEEDER BUS WAY (Continued)}

b. Housing shall be of fabricated sheet metal providing mechanical protection for the conductors and shall include mounting rails to which hangers may be attached at any point. Housing shall be finished in medium - light gray enamel, Federal standard 595, color no. 16329 over a rust inhibitive primer.

c. Bus bars shall be silver plated at all contact points and braced for the specified short-circuit rating. Entire system shall be polarized.

d. Hangers shall be provided for mounting as shown on the drawing.

e. The busway shall be ratea 3000 ampere continuous, 50,000 amperes RMS asymmetrical short circuit, 3 phase, 3 wire with half neutral, 600 volts. Voltage drop shali not exceed $1 / 2$ volt per 100 feet at 80 per cent power factor with rated load.

f. Busway shall be of the ventilated, outdoor type. Bus bars shall be of aluminum and shall be wrapped with four layers of weatherprocf, self-sealing, insulating tape for their entire length except at joints. Joints shall have boot-type enclosing covers. The joint shall be designed in such a manner that it is possible to assemble the joint entirely from one side of the busway.

\section{METAL CLAD SWITCHGEAR}

\subsection{TYPE AND SERVICE}

The switchgear shall consist of an indoor, metal enclosed assembly arranged as shown on drawing H-3-20292. The entire assembly, equipment components: and construction shall conform to the general requirements of Hanford Standard Specification HWS-8001-S. The switchgear shall be suitable for the control of equipment and circuits arranged for operation on a grounded wye system rated 480 volts, three phase, three wire, sixty cycles which is shown on the one line diagram, drawing No. H-3-20292. The switchgear power buses in the assembly shall have a continuous current rating as follows:

\section{a. Normal power section - 3000 amps}

b. Emergency power section - 600 amps

Control voltage for operation of relays and tripping of certain air circuit breakers shall be 48 volts, 2 wire DC, supplied from substation batteries which are described in Section 9 of this division. 


\subsection{NORMAL BUS SECTION}

The normal bus incoming-line air circuit breaker shall be rated for 480 volts with a maximum design voltage rating of 600 volts. Current rating shall be 3000 amperes at 60 cycles. The breaker shall have an interrupting rating of 100,000 RMS anperes, asymetrical, at rated voltage. The breaker shall operate electrically with stored energy mechanism. The breaker shall have a shunt trip for operation on 48 volts $D C$ as auxiliary relays will be used for overcurrent and fault protection. The following auxiliary equipment shall be furnished with the breaker:

a. 3-Adjustable time overcurrent relays with extremely inverse stardard time current characteristics and 4 to 16 ampere time unit. (51) (See drawing H-3-20292).

b. 1-Auxiliary relay, $48 \mathrm{vclt}$ DC operating coil, hand reset with $3 \mathrm{~N} .0$. and 3 N.C. contacts. (86) (See drawing H-3-20292).

c. 3-Current transformers, ratio $3000 / 5$.

d. 4-Potential transformers, ratio 480-120 volt, with current limiting fuses. (2 for line section and 2 for bus section).

e. I-Ammeter switch, shorting type with engraved escutcheon plate, "A", "B", "C", and "Off". "Off" position to short all C.T.'s.

f. I-Indicating A.C. ammeter, single 5 ampere element, 0-3000 ampere. 7.1 inch, $250^{\circ}$ scale.

g. 1-Circuit breaker control switch, pistol grip handle with red and green indicating light.

h. 1-Voltmeter transfer switch with engraved escutcheon plate to read "A-B", "B-C", "C-A", and "Off", "incoming line", and "A-B", "B-C", "C-A",- "Bus".

i. 6-Feeder Air Circuit Breakers, Nos. 7, 8, 9, 10, 11 and 12, rated 600 ampere trip, 480 volts, 35,000 amperes asymetrical interrupting rating, TPST, drawout type, manual operation with stored energy mechanisms, dual magnetic series overcurrent trips, having adjustable time and instantaneous overcurrent protection, and clamp type cable terminals.

j. One compartment completely wired and fitted for one future 600 ampere air circuit breanter equivalent to breakers described in 8.2 i. above. 


\subsection{BUS-TIE SECTION}

The bus-tie air circuit breaker shall be rated for 480 volts with a maximum design voltage of 600 volts and a current rating of 600 amperes at 60 cycles. The breaker shall have an interrupting rating of 35,000 RMS amperes (asymmetrical) at rated voltage. The breaker shall operate electrically with stored energy mechanism and shall be provided with a shunt trip for operation on 48 volts DC. The trip will be operated by auxiliary relays remote from the breaker. The following auxiliary equipment shall be furnished with the Bus-Tie breaker:

a. 3-Current transformers ratio, 2000/5.

b. 3-Adjustable time overcurrent relays with extremely inverse standard time current characteristics and 4-16 ampere time unit (5I).

c. 1-Auxiliary relay, 48 volts, D.C. operating coil, hand reset, with $3 \mathrm{N.O}$, and $3 \mathrm{~N} . \mathrm{C}$. contacts $(86)$.

\subsection{EMERGENCY BUS SECTION}

The emergency bus incoming line air circuit breaker shall be rated for 480 volt service with a maximum design voltage of 600 volts and a currert rating of 600 amperes at 60 cycles. The breaker shall have an interrupting rating of 35,000 RMS amperes (asymmetrical) at rated voltage. The breaker shall operate electrically with stored energy mechanism and shall be provided with a shunt trip for operation of 48 volts DC. In addition, the breaker shall have adjustable, dual magnetic, series overcurrent trip with time and instantaneous elements for overcurrent protection. The following auxiliary equipment shall be furnished with the emergency bus:

a. 3-Current transformers, ratio $300 / 5$.

b. 4-Potential transformers, ratio 480-120 volts with current limiting fuses (2 for line section and 2 for bus section).

c. I-Ammeter switch, shorting type, with engraved escutcheon plate, "A", "B", "C", and "Off". "Off" position to short all C.T.'s.

d. I-Indicating A.C. ammeter with single 5 ampere element and 0-300 ampere, 7.1 inch, $250^{\circ}$ scale.

e. 1-Voltmeter transfer switch with engraved escutcheon plate to read "A-B", "B-C", "C-A" and "Off" - "Incoming Line" and "A-B", "B-C", "C-A" - "Bus". 


\subsection{EMERGENCY BUS SECTION (Continued)}

f. I-Adjustable A.C. instantanecus undervoltage relay, with 115 volt, 60 cycle operating coil adjustable from 55 to 140 volts, to close contacts on decreasing voltage.

g. 1-Auxiliary A.C. timing relay, time adjustment from 20 cycles to 20 seconds, 115 voltage A.C. 60 cycle operating coil, two normally open, and two nomally closed contacts (relay times out after energization of operating coil).

h. 3-Feeder Air Circuit Breakers, nos. 4, 5 and 6 rated 600 ampere with 225 ampere trip coil, 480 volts, 35,000 ampere asymmetrical interrupting rating, TPST drawout type for manual operation with stored energy mecharisms, adjustable dual magnetic series overcurrent trips with time and instantanecus elements for overcurrent protection and clamp type cable terminals.

i. One compartment completely wired and fitted for one future 600 ompere air circuit oreaker equivalent co ureaker's desribed in

\subsection{OPERATION OF UNDERVOLTAGE TRANSFER}

Under normal operation, power is supplied to the emergency bus through the bus tie breaker from the normal bus, and the emergency incoming line breaker No. I is normally open.

Upon loss of voltage to the emergency bus, the operation of relay (27) starts the operation of the timing relay ( $T$ ) if there is power on the emergency incoming line side of breaker No. 1. Upon completion of the timing operation, the timing relay ( $T$ ) trips the bus tie breaker No. 3 and closes the incoming line breaker No. $I$.

Breaker No. 3 must be open before breaker No. 1 can close. This inter. lock will be through the use of auxiliary contacts on breaker No. 3 in the "close" and "trip" circuit of breaker No. 1. Through double electrical interlocks, it shall be impcssible to close both breakers No. 3 and No. $I$ at the same time. This is to prevent the paralleling of two systems which may be out of synchronism.

\subsection{OPERATION OF BUS TIE BREAKER}

Faults on the emergency bus when supplied by the bus tie breaker will cause the operation of the bus tie cvercurrent relay (51). This relay will trip the lockout relay (86) which will then trip the bus tie breaker and block the operation of the undervoltage transfer to emergency power source. 


\subsection{RELAY COORDINATITON}

The power system furnished under this division of the specification shall have overcurrent coordination for selective tripping with overcurrent settings similar to those shown on time-current curve sheet, drawing $\mathrm{H}-3-20358$.

\subsection{LIFTING DEVICE}

A circuit breaker lifting device shall be provided on track type supports above each breaker unit for use in raising and lowering any size breaker to any compartment. The lifting device shall retract to the front surface of the switchgear so as not to obstruct the aisle in front of the gear when the lifting device is not in use.

\subsection{POWER CABLE TERMIINATIONS}

Each feeder breaker shall be supplied with clamp type cable connectors to accomodate the following wire sizes:

Breaker No. $4-1-4 / 0$ per $\phi$

$$
\begin{array}{r}
5-1-4 / 0 \text { per } \phi \\
6-1-4 / 0 \text { per } \phi \\
7-2-350 \mathrm{MCM} / \phi \\
8-2-350 \mathrm{MCM} / \phi \\
9-2-350 \mathrm{MCM} / \phi \\
10-2-350 \mathrm{MCM} / \phi \\
11-2-350 \mathrm{MCM} / \phi \\
12-2-350 \mathrm{MCM} / \phi
\end{array}
$$

\subsection{GROUND BUS}

The ground bus specified in HWS- $8001-S$ shall be connected to the neutral bus in the low voltage feeder busway with cable or bar equal in size to the ground bus. The ground bus shall have clamp type terminals for ground cables as follows:

1 size 4/0 for each 225 amp. feeder breaker.

2 size 4/0 for each 600 amp. feeder breaker

2 size 4/0 for building ground cables.

9. D.C. TRIPPING POWER SUPPLY

The D.C. tripping power supply system shall consist of the following: 
a. 1 - 48 volt D.C. nickel-cadmium battery with 20 ampere-hour capacity sufficient for switchgear tripping and relay duty.

b. 1 - Power rectifier for charging of 48 volt battery complete with automatic self-regulating electronic voltage regulation. The unit shall include a D.C. ammeter and a D.C. voltmeter. Primary voltage shall be 120 volt, 60 cycle, single phase. The charging level shall be manually adjustable.

c. 1 - Automatic throw-over switch for transfer of control power from one source to another, 480 volt operating coil, two pole double throw, mechanically held, 30 ampere, 600 volt contact rating.

d. 1 - Control transformer 480/120 volt, for power supply to battery charger and operation of stored energy motors on air circuit breakers.

e. 1 - Set of two current limiting power fuses, 20 ampere, 600 volts for connection to emergency bus and automatic throw-over switch.

f. 1 - Set of two current limiting power fuses, 20 ampere, 600 volts for connection to normal bus and automatic throw-over switches.

10. KEY INTERLOCKS

a. Key interlocks shall be provided between the transformer primary disconnect switch and the transformer main secondary breaker. These key operated interlocks shall prevent the opening of the primary switch except when the secondary breaker is in the open position.

b. One set of locks and two keys (one a spare) shall be provided for interlocks between the primary disconnect switch on the 225 KVA emergency power transformer and the 480 volt breaker No. 1.

c. One set of locks and two keys (one a spare) shall be provided for interlocks between the primary disconnect switch on the $1680 \mathrm{KVA}$ normal power transformer and the 480 volt breaker No. 2.

d. The lock mechanisms shall be different for the two systems such that keys for the emergency locks will not operate in the normal power interlock system.

\section{SHORT CIRCUIT TESTS}

A short circuit test shall be made on the switchgear, specified in this division, at the manufacturer's plant before shipment, to test whether or not the bus will withstand 50,000 amperes short circuit 
11. SHORT CIRCUIT TESTS (Continued)

satisfactorily. The test will consist of bolting a shorting bus bar across the 3000 ampere bus at the extreme end opposite the inccming feeder connection. A short circuit of approximately 50,000 RMS amperes will be applied to the bus for a minimum of 10 cycles. If any damage to the bus or appurtenances should occur, the Contractor will be required to make all repairs at his own expense. Subsequent tests will be made on the equipment until it passes the final test satisfactorily. It is required that a representative of the Commission shall be present to witness the test.

12. INSTALLATION OF EQUIPMENT

The transformers, busways and switchgear shall be installed at the locations shown on the construction drawings in accordance with the manufacturer's installation instructions and approved erection drawings and the requirements of this specification.

13. INSPECTION AND TESTING

The substation and switchgear shall be inspected and tested in accordance with the requirements stated in sections 44.6 and 44.7 in Division XVII of these specifications. 
DIVISION XIX

COMMUNICATIONS SYSTEMS AND BUILDING ALARMS

\section{GENERAL}

1. $\mathrm{SCOPE}$

This division covers the telephone system and the paging and alarm systems for the Fuels Recycle Pilot Plant, Building 324 .

2. SUBMISSION OF DRAWINGS AND INFORMATION

The Contractor shall furnish to the Commission, dimensional outlines, complete wiring diagrams, installation instructions, maintenance instructions, performance data and spesifications for the equipment specified herein in accordance with the Special Conditions.

The drawings and information shail be furnished as follows:

a. Data submitted for approval and comment prior to purchase and installation.

b. Certified data submitted for the permanent files showing equipment as furnished and installed.

\section{MATERIAIS}

\section{TELEPHONE EQUIPMENT}

a. Telephone instmments and PABX equipment including attendant's cabinet will be furnished and installea by the Commission.

b. Telephone wire between main terminal cabinet and telephone outlets shall be PVC insulated, NO. 22 AWG, telephone wire, twisted pair Whitney Blake Co., "Plastite" No. 22 PN-2, or approved equal.

c. The duct system in the second floor office area shall be a prefabricated metal, surface wiring system. Elbows and fittings used shall be products of the same manufacturer as the duct used. Duct shall be fitted with 6-inch long, removable cover sections at outlets. Covers shall have a muber gromet in the outlet hole. Duct shall be of the size shown on the drawings and shall be Wiremold No. 2200, or approved equal. 
3. TELEPHONE EQUIPMENT (Continued)

d. The main telephone terminal cabinet shall be furnished by the Contractor and shall be as spesified on drawing H-3-20239.

d. Conduit, raceways, pull boxes and accessory fittings shall be as specified in Division XVII.

f. Telephone connecting blocks shall be furnished and installed at all telephone outlet boxes. Telephone connecting blocks are not required at outlets in the duct system.

4. PAGING AND BUILDING ALARM SYSTEM

\subsection{MICROPHONE}

The microphone shall be of the uni-directional (cardioid), dynamic type with a uniform frequency response of 50 to, 10,000 cps. It shall be mounted on a special desk stand with the zone control switches. The output shall be 150 ohm impedance at a levell not lower than -55 db. Finish shall be satir chrome. Ten feet of shielded, two-conductor, microphone cable shall be fumished with plug and receptacle in the microphone outlet box. Microphore shall be (I) Electro-Voice Model 664 , (2). Turner Model 98, (3) Schure Model 55s orr (4) Astatic Model 77, or an approved equal.

\subsection{MTXER-PREAMPLIFIER}

The mixer-preamplifier shall have a minimum of five microphone inputs ( 4 used and one spare). Inputs shall be low impedance (or with input transformers of 50-150 ohms primary impedance). Each input channel shall have a separate lockable gain control. The master gain control, if used, shall be provided with a knob or shaft: lock. The output impedance shall be $600 \mathrm{ohms}$ at $+18 \mathrm{db}$. minimum with $2 \%$ or less distortion. The unit shall have a frequency response of \pm 2 ab from 60 to 10,000 cps. A treble tone control for all charnels shall be provided with a minumum range of $+12 \mathrm{db}$ at $10 \mathrm{kc}$. The signal sshall be attenuated below $350 \mathrm{cps}$ at the rate of $10 \mathrm{dk}$ per octave. Eithesr a lockable bass tone control or fixed low-frequency filter shall be used. The preamplifier shall be self-powered and for operation at 1200 volts, 60 cycles. It shall be mounted on a standard 19 inch rack pamel with slides. The mixer-preamplifier shall be Bogen Model MXM, Nerwcomb $\mathrm{KX}-6 \mathrm{~A}$, Grommes Model G-5M, or an approved equal, suitably modiffied as specified herein.

\subsection{POWER AMPLIFIERS}

The power amplifiers (booster amplifiers) shall be three units, each rated at least 100 watts program material powerw output. The amplifiers 


\subsection{POWER AMPLIFIERS (Continued)}

shall be connected and cpsrated in parallel, and failure or removal of one unit shall rot affest the operation of the other two. The output shall fieed ard match the 70.7 volt audio distribution system. Input impedarce shall be 500-600 chms. The frequensy response shall be $\pm 2 \%$ from 60 to 10,000 ops ard the total distortion shall not exceed 5\% at 100 watts output. Hum and roise shall be at least 60 $\mathrm{ab}$ below ratel output. The amelifiers shall be for operation at 120 volts, 60 cysies and shall be equipped with line fuse, switch and pilot light. They shall be mounted or a standard 19 inch rack panel with all necessary hardware so that they can be removed from the front of the rack cabinet. All resessary plugs, transformers and cables for intercornections shall be proriasd. Each power amplifier shall have a plate curreat relay ircorporated on the amplifier chasis, connected to remove the $B+$ supply frcm the oxtput tubes when the relay is de-erergized. Relays shall be operated from the 24-28 volt, d-c audio control circuit as shown on 2rawing H-3-20331. The amplifiers shall be Bogen Model MOLOO, or approved equal.

\subsection{AMPLIFIER AND RELAY RACK CABINET}

A rack cabinet to house the amplifiers specified in Sections 4.2 and 4.3 above shall be furnished axd located as shown on the drawings. The cabiret shall also contain a wiring space with terminal blocks for the connection of all wiring external to the cabiret and section for the cortrol relays and the 24 volt power supply. Plug-in relays shall be use with industrial type sockets. All internal wiring shall be neatly trained and cabled, and supported where recessary with insulated clips or cable bande. Ior-level audio wiring shall be separated from alternating ourrent power wiring. Forced ventilation shall be provided. All chasis sinell be grounded by means of 3-wire power cords, caps and receptacies ard the cabinet shail be grounjed through the supply circuit conouit.

\subsection{SOUND BOX}

The sound box shall be constmuted as shown on drawing H-3-20332. It shall be suspended from the eeiling with 200 lb test nylon rope. Cables and cords snall be provided with loaking plugs and receptacles in the cabinet. Space shall be provided for a fourth pair of receptacles for possible future adjitiox of arother soundirg device.

\subsection{PAGING AND ALARM SPEAKERS}

The paging and alarm speakers shall be high-efficiency horn-typs urits. The speaker location and type are shown or the schedule on drawing H3-20330. Drivers shall be 4, 8 or 16 ohms impelance. Unless other- 


\subsection{PAGING AND ALARM SPEAKERS (Continued)}

wise stated kelow they shail have a erequency range of 350 to $8000 \mathrm{cps}$. Speakers shall be furnished coxplete with mounting brackets. All types are for indoor use exeep's as noted below. All power ratings are for program material above low-frequexcy hora cut-off。

a. Rewentrant, round hcres - Type I speakers shall be rated a minimum of 15 watts. Speakers shali be rcund recentrant, horn type with 90 to 100 degree dispersion argle. Speakers shall be ElectroVoice 844, Uriversity MII-A, Atias HU-15N or approved equals.

b. Re-entrant, round hom - Thpe II speakers shall ke rated not less than 40 watts with a 60 to 95 degoe dispersion. They shall be heavy-duty, mourd-kom, resentrant type urits, and shall be Uriversity $C R$, Racon $R E 25$ horn with FM-623 driver, Jensen H-150 hors with Dou do driver, or approved equal.

c. Wide-angle - Type I speaxers stall have a 7.5 watt minimum ratirg. They shall be a re-extrast rectangular horn type with a dispersion angle of at least 120 by 60 degrees. Low frequency response shall not be less thax 400 ops. Skeakers shall be University CMII-A, Atlas CJ-I4N, or approved equal.

d. Wide-argle - Tyce II speaikars shall be the same as specified in paragraph cabove except a larger size with power rating of 25 watts ard a low-frequercy 1 imit of $250 \mathrm{cps}$. They shall be ElectroVoice 847, University $C I B-A$, Atlas $C J-30 N$, or approved equal.

e. Bi-directional speakers shall be re-entrant, dual homs with a single driver with a mininim power rating of 25 watts. The highfrequeroy responze shail, ret be less than 6000 eps. Speakers shall be University 2WP hom with ID-co driver, Atlas TP-15N or two Electro-Vsice 84if Uzís, or appocved equal.

f. Weatherpoct speakers shall be heary duty urits for use outdocrs on in wet Iscations. The power $=0$ ang shall be not less than 40 watts. High-frequensy response shall be at least $5000 \mathrm{cps}$. Weatherprof speakers siali be furrished with a weatherproof transformer housing and shall be University MM-2L, Rasox MG-2I-B, Atlas CJ-44, or approved equal.

\subsection{TRANSFORMERS}

Iine to voice coll, impedarce matchirg trassforners shall be installed as shown on the drawings at each speaker lccatton. The power rating in watss of each tramstommer shall he rot lese thax shows in the schedule on 


\subsection{TRANSFORMERS (Continued)}

drawing H-3-20330. There shall be at least five power taps on each transformer at $3 \mathrm{db}$ intervals lower than rated power. Taps shall be arranged on a solderless plug-in teminal board. The initial power setting shall be approximately $25 \%$ of the transformer rating as shown in the schedule.

\subsection{AUDIO CONDUCTORS}

a. Wiring between the microphone and pick-up speakers shall be standardduty, two-conductor (10w Impedarice) No. 22 AWG shielded microphone cable, and shall be Alpha Wire Corp. No. 1710, or an approved equal.

b. Wire for the 70.7 volt audio distribution system shall be twisted pair No. I6AWG stranded with plastic jacket - Alpha Wire No. 1899, or an approved equal.

c. The control cable from rack cabinet to microphone desk stand shall be 8 conductor No. 22 AWG with PVC insulation and cotton braid or plastic jacket - Alpha Wire No. 1188, or approved equal.

5. LOBBY ANIUNCIATOR

a. The lobby annunciator shall be suitable for flush mounting in the plaster wall as shown on drawing H-3-20332. A suitable frame and brackets shall be provided. The annunciator shall be of the backlighted-nameplate type having windows allowing for an engraving space of approximately $2^{\prime \prime}$ high by $3 "$ wide. It shall have a total of 48 positions and shall be eight units wide and six units bigh. Acknowledgement and test push buttons shall be provided in a separate flush mounted enclosure. The first row of nameplates shall be red translucent plastic, and all others shall be white translum cent plastic. Nameplates shail be as shown on drawing H-3-2033I. Blank nameplates shall be provided for all unused positions. The individual nameplates shail be removable without the use of tools. Each nameplate shall be lighted with two six watt lamps in parallel. The cabinet door shall be supplied with a continuous hinge along the entire left side for adequate support of the door. The metal face of the cabinet shall be firished in a baked-on, light gray enamel.

b. The relays shall be located within the cabinet, and shall be of the plug-in type. Relays shall be mounted in hermetically sealed, gas filled cans. Positions 25 through 48 shall be provided with complete chases and terminal blocks but shall be without relays.

c. The annunciator shall be the "fail-safe" type with both relays per station normally energized. Should either relay fail, the buzzer 
5. LOBBY AINUNCLATIOR (Continued)

shall sound and the lamp of that station shall flash. The circuit shall allow either normally-closed or normally-open signal contacts to be used. Auxiliary contacts shall be normally open, and these contacts shall be wired to individual terminals on the terminal block.

d. The system shall be for operation on 120 volt, 60 cycle, singlephase, power supply.

e. The operational sequenee shall be as follows:

CONDITION

Normal

Alert

Audible silence

(Acknowledge)

Normal.

Operational Test
NAMEPLATE IAMP

Off

Flashing

Steady-on

Off

Flashing
SIGNAL LAMP AND

AUDIBLE SIGNAL

Off

Off

off

off

On

f. The audible signal shall be a buzzer for indoor use and for surface mounting. The buzzer shall provide a sound level of approximately $89 \mathrm{db}$ at a distance of 10 feet.

6. CONTROL ROOM ANNUNCIATOR

a. A lamp cabinet without relays shall be provided for the control room, and shall operate from the auxiliary contacts of the lobby anrunciator. The cabinet shall be similar to the lobby annunciator except that it shall be for surface mounting. The same nameplate schedule shall be used as shown on drawing H-3-2033I for the lobby annunciator. Acknowledgement and test push buttons shall be located in a separate exclosure as shown on the drawings and shall be connected in parallel with those of the lobby arnunciator.

b. The cabinet shall be designed to be supported by means of brackets or by direct attachment to the wall. Terminal blocks shall be accessible from the front of the cabinet when the hinged light box compartment is opened.

c. A buzzer, identical to that specified in Section 5 for the lobby annuciator shall be supplied.

d. Each annurciator position shall be lighted by two six watt lamps in parallel. One side of the lamps in each row shall be cormon, while the 
6. CONTROL ROOM ANNUNCIATORS (Cont,irued)

other side of each pair of lamps shall be wired to the terminal strip for connecting to the lobby annunciator.

e. The annunciator cabinet shall be finished in a baked-on, light gray enamel.

7. INSTALIATION OF COMMUICATION SYSIEES AND BUILDING ALARMS

7.1 GENERAL

The installation of electrical systems and equipment covered by this division of the specifications shall be governed by the same requirements specified for other electrical work in Division XVII, except where specifically shown otherwise on drawings H-3-20228, 29, 30, 31 and 32 .

\subsection{TELEPHONE SYSTEM}

a. The completed telephone system will be a private automatic exchange. The Contractor shall install all conduit, raceways, ducts, pull boxes, outlet boxes, accessory fittings and the main telephone terminal cabinet.

b. The telephone instruments, the PABX equipment and the attendants equipment in the lobby will be installed by the Commission at a later date.

c. The Contractor shall install one pair of No. 22 AWG telephone wires from each outlet shown on the drawings to the main telephone terminal cabinet. A connecting block and cover shall be installed at each box outlet. Conrecting blocks shall not be installed at duct outlets in and Floor offices.

\subsection{PAGING SYSTEM AND BUIIDING ALARMS}

a. The completed system will be a zoned public address system for paging and voice communication combined with distribution of building alarm sounds for critical incident (howler), fire (bell) and civil defense (siren).

b. The alarm sounders (howler, bell and siren) shall be located in the compartmerted sound box as showr on drawing H-3-20332. The fire alarm signal will be relayed from the fire alarm supervisory panel in the lobby. The civil defense alarm will be activated by a signal originating in the 300 Area $C D$ headquarters and transmitted to the building via a telephone pair. The critical incident 


\subsection{PAGING SYSTEM AND BUIIDING ALARMS (Continued)}

alarm will be activated by a signal from any one of five radiation detection instruments located in the building as shown on drawing H-3-20328. The radiation detection instruments will be furnished by the Commission to the Contractor for installation.

c. The signals shall activate the correct relay to sound the associated alarm and automatically channel the amplified sound to the speakers in all zones of the building.

\section{INSPECTION AND TEESTING}

\subsection{TELEPHONE}

Check for continuity and correct labeling of each pair from the main telephone terminal to each telephone outlet.

\subsection{PAGING SYSTEM}

a. Provide a typical voice signal into the microphone at normal speaking volume.

b. Set the master and microphone channel pre-amplifier gain controls at $50 \%$. Note the sound level at each speaker area. Adjust the transformer tap as necessary to increase or decrease the desired sound intensity.

c. Actuate each alarm signal. Adjust the channel gain control on the pre-amplifier to the desired sound intensity. Remove the knobs and lock gain controls in position.

(1) The fire alarm signal shall be generated by operating a pull box.

(2) The civil defense signal shall be generated with a $1-1 / 2$ volt battery.

(3) The critical incilent alarm shall be sounded by manually operating the relay in each of the five radiation detection instruments. 


\section{DIVISION XX}

\section{INSTRUMENTATION}

\section{GENERAL}

\section{SCOPE}

a. This division covers instrumentation for the Fuels Recycle Pilot Plant, Building 324, other than that required for the heating and ventilating system. Testing of individual instruments and complete systems is also included.

b. Mechanical supports and brackets, electrical and pipe fittings and other small miscellaneous items, which are not detailed on the drawings but are required to connect and support instrumentation components, or to meet the requirements of the National Electrical Code, shall be provided by the Contractor.

c. The following phases of work are covered by other divisions of these specifications:

$$
\begin{aligned}
& \text { Piping work - Division VI Piping \& Plumbing } \\
& \text { Electrical work - Division XVII Electrical }
\end{aligned}
$$

\section{REFERENCED STANDARDS AND SPECIFICATIONS}

The standards and specifications listed below form a part of these specifications to the extent indicated by subsequent references.

2.1 AMERICAN SOCIETY FOR TESTING AND MATERIALS (ASTM)

ASTM B75-61, Seamless Copper Tube

ASTM B210-61, Aluminum-Alloy Drawn Seamless Tubes

\subsection{HANFORD STANDARDS AND SPECIFICATIONS}

HWS-7200-S, Rev. 2, Instrument Panel Piping and Wiring $\mathrm{J}-2-4$, Rev. 2, Instrument Panel Curb

$\mathrm{J}-2-7$, Instrument Fanel Nameplates

$\mathrm{J}-3-1 a$, Space Behind Instrument Panels

\section{SUBMISSION OF DRAWINGS AND INFORMATION}

a. The Contractor shall furnish the following items, to the Commission for approval, 30 days prior to purchase of instruments or fabrication of instrument panels: 


\section{SUBMISSION OF DRAWINGS AND INFORMATION - Continued}

a. (Continued)

(1) Complete, dimensioned, working drawings of the instrument panel

(2) Manufacturer's specifications for instruments to be furnished.

(3) Instrument panel wiring and piping diagrams

b. At the time of shipment of instruments and panels from the factory the Contractor shall furnish the following items to the Commission:

(1) Approved installation drawings

(2) 'Instrument operating and maintenance instructions

(3) Instrument manufacturer's suggested spare parts lists

c. At the time of completion of the work and prior to acceptance of the control systems, the Contractor shall furnish to the Commission one set of drawings of the control systems, revised to show the actual as-built conditions of instrument panels and circuit arrangements.

\section{MATERIAIS}

4. TUBING

a. Copper tubing shall conform to the requirementss of ASTM B75, annealed temper, unless shown otherwise on the drawings. Wall thicknesses shall be as follows:

$$
1 / 4^{\prime \prime}-0.030^{\prime \prime}, 3 / 8^{\prime \prime}-0.032^{\prime \prime}, 1 / 2^{\prime \prime}-0.035^{\prime \prime \prime}
$$

b. Aluminum tubing where called for on the drawings shall conform to the requirements of ASTM B210, alloy 6061-T4. Wall thicknesses shall be as follows:

$$
1 / 4^{\prime \prime}-0.035,3 / 8^{\prime \prime}-0.042,1 / 2^{\prime \prime}-0.049
$$

c. Fittings for copper and aluminum tubing shall be wrought or bar stock brass, SAE $45^{\circ}$ flared, unless shown otherrwise on the drawings. Cast fittings are not acceptable.

5. CONDUIT

Conduit and fittings for instrument wiring shall bee rigid steel or aluminum conforming to the requirements stated in DDivision XVII. 
6. INSTRUMENT CONTROL PANELS

a. The Contractor shall assume responsibility for the method of fabrication and erection within the limits of the referenced Hanford

Standards and Specifications. The Contractor shall furnish the panels with all instruments and appurtenances as stipulated herein, to make a complete and well integrated assembly.

b. The panel arrangement as shown on the contract drawings shall be followed closely. Minor deviations may be required to accommodate certain instrument components. The exact arrangement proposed by the panel manufacturer shall be submitted to the Commission for approval as one of the working drawings specified in section 3 above.

7. INSTRUMENTS

The following instrument specifications supplement the information shown on the construction drawings referenced.

7.1 SHUNTFLO METER - Part No. 1, Drawing H-3-20373

Fluid

Pressure

Main line size

Meter size

Main line flow

Main line capacity

Includes

Motor calibration

Mark
- Saturated steam

- 125 psig

- 8", sch. 40 with 150 Ib. ASA flanges

- 2" bypass

- horizontal

- Normal 25,000 1b. per hour

- Maximum 50,000 1b. per hour

- Main line orifice, valves and bypass assembly

- Pounds of steam

- EPN 324-5903-401

7.2 PRESSURE SWITCH - Part No. 12, Drawing H-3-20373

Range

Enciosure

Contact rating

Contact action

Trip adjustment

Mounting

Pressure connections

Electrical connection

Mark
- 0 to $200 \mathrm{psig}$

- NEMA Type 1

- 5 amps at 120 volts, 60 cycles, A-C

- Close on decreasing pressure

- Adjustable between 10 and 180 psig

- Surface mounting

- 1/4" NPP male thread

- For $1 / 2^{\prime \prime}$ rigid conduit

- EPN 324-5903-405-1

7.3 PRESSURE SWITCH - Part No. 24, Drawing H-3-20373

Range

- 0 to 250 psig 
7. INSTRUMENTS

7.3 PRESSURE SWITCH - Continued

Enclosure

Contact rating

Contact action

Trip adjustment

Mounting

Pressure connections

Electrical connection

Mark
- NEMA Type 1

- 5 amps at 120 volts, 60 cycles, A-C

- Close on decreasing pressure

- Adjustable between 20 and 200 psig

- Surface mounting

- 1/4" NPT male thread

- For $1 / 2^{\prime \prime}$ conduit

- EPN-324-5903-405-2

7.4 TEMPERATURE INDICATOR - Part No. 12, Drawing H-3-20388

$\begin{array}{ll}\text { Range } & \text { - O to } 400 \mathrm{~F} \\ \text { Type } & \text { - Potenticmetric circuit } \\ \text { Calibration } & \text { - Type "J" (iron-constantan) } \\ \text { Size } & \text { - Approx. } 7^{\prime \prime} \times 7^{\prime \prime} \times 18^{\prime} \text { deep } \\ \text { Power } & \text { - l20 volt, } 60 \text { cycle, A-C } \\ \text { Dial } & \text { - Circular with approx. } 250^{\circ} \text { rotation } \\ \text { Standardization } & \text { - Continuous with constant voltage supply } \\ \text { Calibrated accuracy } & \text { - t } 0.25 \% \text { of full scale } \\ \text { Speed of response } & \text { - Nominal } 3 \text { seconds for full scale travel } \\ \text { Reference Junction Compensation - Fully automatic } \\ \text { Controls } & \text { - None } \\ \text { Mounting } & \text { - Flush panel mount } \\ \text { Representative type } & \text { - Thermo Electric Co. Inc. } \\ & \text { Saddle Brook, N.J. Model } 80249\end{array}$

7.5 THERMOCOUPLES - Part No. ITE-6 thru 6TE-6, Drawing H-3-20366

Type

Calibration

Wire Gauge

Sheath Material

Length

Hot Junction

Sheath Diameter

Representative Type:

Mark
- Swaged $\mathrm{MgO}_{\mathrm{g}}$ insulated

- ISA Symbol J (Iron-Constantan)

- No. 22 B \& S

- Aluminum

- As specified on drawing

- Closed tip, isolated from sheath

- 1/8 inch O.D.

- Thermal Electric Co., Inc. Saddle Brook, N.J., Type CeAl-18-AT, or approved equal

- No. ITE-6 thru 6TE-6 as indicated by length on drawing 
7. INSTRUMENTS - Continued

7.6 PRESSURE INDICATING CONTROLLER - I Requirea, Drawing H-3-20476

Input:

Scale:

Element:

Control:

Supply Air:

Output:

Mounting:

Setpoint:

Connections :

Mark:
(Distilled Water Heat Exchanger)

- 0 to 80 inches water

- 0 to 80

- Stainless Steel, welded bellows

- Differential Gap, on-off, adjustable from 1 to 100 percent of span

- 20 psig

- 15 psig air

- Wall or pipe mounting

- Knob adjustable, with pointer to indicate setpoint

- I/4 inch NPT

- EPN $324-445$

7.7 PRESSURE SWITCH - 3 Required, Drawing H-3-20385

Range:

Fluid:

Action:

Contacts:

Enclosure:

Connections:

Mounting:

Representative Type:

Mark:
- 0 to 20 psig, nominal

- Compressed air

- Contacts to close on decreasing pressure

- One SPDT, rated 5 amperes at 120 volts, AC

- General purpose, manufacturer's standard

- 1/4 inch NPT, female, input 1/2 inch NPS conduit

- Surface wall type

- Barksaale valves Catalog No. DIT-HI8, or approved equal

- (1) Bldg. 324-1 PS3

(1) Bldg, 324-3 PS3

(1) BIdg. 324-2 PS3

\section{THERMOCOUPLE WIRE}

a. Thermocouple wire, to be used between junction boxes near waste tanks and panel mounted indicators, shall be $22 \mathrm{~B} \& \mathrm{~S}$ gauge,

ISA symbol " $J$ " (iron constantan), polyvinyl duplex rip-cord. The wire shall be marked $1 \mathrm{TE}-6$ through $6 \mathrm{TE}-6$ to correspond to markings of the thermocouples to which it is attached.

b. Thermo Electric Co. No. P-26-DT is a representative type meeting the requirements stated in (a) above. 
9. FABRICATION AND INSTAIIATION OF INSTRUMENT PANEISS

a. Piping and wiring for instrument panels shall be fabricated and installed as specified in Hanford Standard Specification HWS-7200-S. Ends of tubing and wiring shall be identified as specified in HWST200-S.

b. All instrument panels shall be grounded to the building grounding system as specified for other equipment in Division XVII.

c. All instrument panels shall be mounted in accordance with the specification designated on the applicable drawings. If a specification or detail is not given on the drawings, mounting shall be in accordance with Hanford Standards $\mathrm{J}-2-4$ and $\mathrm{J}-3-1 \mathrm{a}$.

10. INSTRUMENT PIPING AND TUBING

a. All joints in tubing shall be located and installed for maintenance accessibility. Tubing shall not be painted.

b. All tubing runs shall be supported by light-weight structural steel units such as "Unistrut", or approved equal, unless specified otherwise on the drawings.

c. All tube bends shall be made with bending tools similar to Parker or Imperial types. After cutting or flaring all burrs shall be removed from tubing ends.

d. Piping and tubing shall not contain unnecessary or unsightly bends or kinks or low points where foreign material could collect. Annealed tubing may be stretched to a maximum of $I^{\prime \prime}$ in $10^{\prime}$ for straightening.

e. Instruments or valves shall not be supported by tubing. Separate brackets or clamps shall be used if valves are connected directly to tubing.

\section{IDENTIFICATION OF TUBING}

Instrument tubing shall be identified at each end with the identification number shown on the drawings. Identification numbers shall be stamped on metal tags which shall be attached to the tubing by wiring or clamping. The tags shall be visible and accessible. 


\section{INSTRUMENT WIRING}

a. All instrument wiring shall be insulated in accordance with applicable portions of the National Electrical Code. Continuity tests shall be made to assure freedom from open circuits and unintended ground connections.

b. No ground connections shall exist except as required by these specifications or where shown on the drawings.

c. All cables shall be marked with the cable identification number at each terminating end with imprirted tubular plastic wire markers similar to the type available from the EPC Corporation, or equal.

a. All thermocouple wires shall be connected to the panel instrument terminal strip. Thermocouple lead wire shall be continuous from the process vessel to the instrument terminal strip, unless otherwise indicated on the drawings.

\section{INSTRUMENT IDENIIFICATION}

All field mounted instruments shall be clearly identified with the application numbers given on the instrument drawings. Nameplates shall be attached to the mounting bracket or to apparatus near the instrument location; not on the instruments. The nameplates shall be similar to those detailed on Hanford Standard J-2-7.

\section{INSTRUMENT INSTALIATION TESTING}

a. During installation and prior to any test work, or instrument connection, piping and tubing shall be cleaned of all foreign materials such as filings, chips, dirt, etc. by blowing out with clean, dry, oil-free air for a period of time as determined by the Commission.

b. All instrument tubing lines shall be subjected to a pressure leak test. Instruments shall be disconnected during pressure testing. Test hook-up and procedure are shown below.

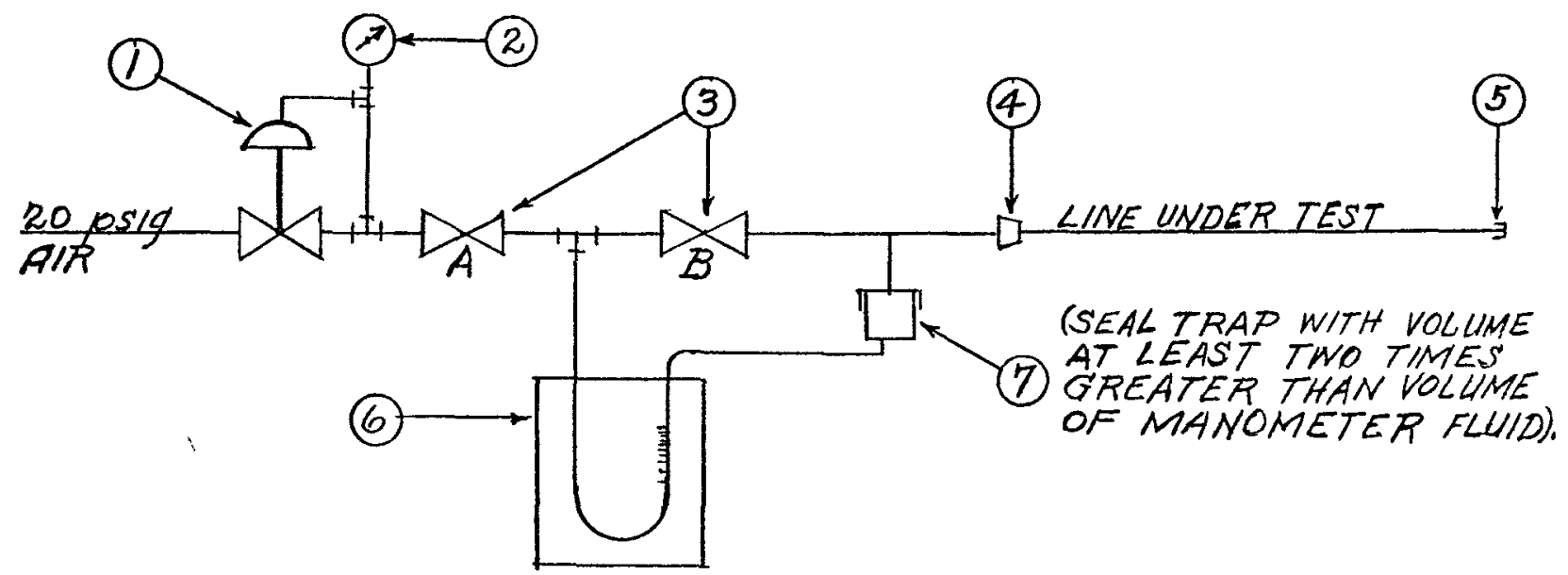


14. INSTRUMENT INSTALIATION TESTING

b. (Continued)

\begin{tabular}{|c|c|c|}
\hline Item & Qty & Description \\
\hline 1 & 1 & Press Red. Valve Conoflow H-20 \\
\hline 2 & 1 & $4 \frac{1}{2} "$ gage, $0-20 \mathrm{psi}$ \\
\hline 3 & 2 & $\frac{1}{4} "$ brass globe valve \\
\hline 4 & 1 & Adapter to connect to line under test \\
\hline 5 & 1 & Cap or plug for line under test \\
\hline 6 & 1 & $24 " U$-tube manometer \\
\hline 7 & 1 & Seal trap \\
\hline
\end{tabular}

\section{OPERATION:}

1. Open valve $B$

2. Open valve $A$

3. Regulate PRV until line under test, and manometer, are at 15 psi

4. Close valve $B$

5. Observe manometer for rise in seal fluid on side connected to line under test. An unbalance of manometer fluid indicates a leak.

6. Close valve A

7. Open valve $B$ before disccnnecting line to prevent blowing manometer fluid.

c. All instrument power wiring shall be checked for continuity and proper connections. The instrumeats shall be disconnected during these tests. After any necessary corrections to the power wiring have been made the instruments shall be reconnected.

d. Proper signal connections between instruments shall be determined by changing the process variable at the detecting element and determining that the proper response is obtained at the measuring instrument. Any errors in wiring shall be corrected. 
DIVISION XXI

VIEWING WIINDOWS

\section{GENERRAL}

1. SCOPE

This division covers the design, fabrication and installation of process cell viewing windows for the Fuels Recycle Pilot Plant Building 324. Dry type and oil-filled windows are included as indicated on drawings $\mathrm{H}-3-2024 \mathrm{I}$, $\mathrm{H}-3-20244, \mathrm{H}-3-20466$ and $\mathrm{H}-3-20247$.

2. SUBMTSSION OF DRAWTIGS AND INFORMATION

a. The Contractor shall furnish to the Commission the following drawings and information covering the equipment specified in this Division and in accordance with the requirements specified in the special Conditions.

(1) Composite shop drawings showing dimensions and method of assembly and including the following:
(a) Type and size of lead glass used
(b) Viewing angles
(c) Index of refraction of various types of glass
(d) Overall dimensions of wall liners
(e) Expansion tank size
(f) Approximate location of vent and drain fittings
(g) Individual band frames and method of setting glass
(h) Approximate weight of each type of window

(2) Specifications for all materials proposed for use including densities of various types of glass.

(3) Manuals containing instructions for cleaning and disassembly of windows.

b. Items (1) and (2) in paragraph a. above shall be furnished to the Cormission for approval, prior to purchase of equipment by the Contractor.

c. Final approved copies of all items listed in paragraph a. above shall be forwarded to the Commission at the time the equipment is shipped to the job site.

3. REFERENCED STANDARDS AIND SPECIFTCATIONS

The standards and specifications listed below form a part of this 
3. REFERENCED STANDARDS AND SPECIFICATIONS (Continued)

specification to the extent indicated by subsequent references.

\subsection{JOINT ARMY-NAVY SPECIFICATIONS}

JAN-G-174 (1), Optical Glass, Class C Striae.

\subsection{INIERRATIONAL COMMISSION ON IIIUMTNATION}

Tungsten Light Quality, Illuminant A.

4. SHIELDIIVG REQUIREMENIS

Window assemblies shall be designed, shaped and constructed to maintain the shielding integrity of the cels wall in which they will be installed. Aggregate fliled window housings shail be as shown on the drawings.

4.1 DRY TYYE WINDOW

The dry type window, which is located in Dor No. 178, shall be equal in shielding to 18 inches of 7.3 specific gravity Meehanite cast iron (13I density inches minimum). The wixdow shall not protrude more than $1 \frac{1}{2}$ " on either side of the door (overall depth 21 " maximum).

\subsection{OII-FIILED WINDOWS}

The oil-filled, laminated lead glass, window assemblies shall: provide shielding equal to four feet of high density concrete of the type specified in Division 3 ( 172 density inches minimum).

5. ENVIRONMENT

The building site is approximately 400 feet above sea level. The cells will be essentially leak-tight and interiors of cells will be maintained at a slightly lower pressure than the surrounding galleries. Temperatures may vary from $40 \mathrm{~F}$ to $150 \mathrm{~F}$.

\section{WINDOW ASSEMBLIY}

a. The steel wall-penetration liners for oil-filled windows shall be sufficiently rigid to withstand the fluid loads imposed during the piacement of the concrete shielding, without distortion.

b. The steel liners, the housings and the windows shall be so designed, fabricated and installed so that an air seal is maintained on the cells.

c. The entire removable assembly shall be leak-tight and sufficiently strong and rigid to prevent damage during shipment, storage and installation. 


\section{WINDOW ASSEMBLLY (Continued)}

d. Windows in the Metallurgical Cells shall be removable from the gallery side of the wall. Windows in the Hot Pilot Cells shall be removable from inside the Cell. Provisions shall be incorporated in all windows to permit attachment of lifting and installation devices.

e. Window housings shall be cleaned of dirt, oil and rust and then painted on the interior with a material suitable for submerged service in the fluid with which the window is to be filled.

f. Band frames holding the non-browning cover glass on the cell side of the Hot Pilot Cell windows shall be Type $304 \mathrm{~L}$ stainless steel. The bolts holding these frames in place shall be any AISI 400 series stainless steel. The annulus betweer the window housing and the cell wall liner on the cell side shall be fitted with a gasket. The backup plate and retainer screws shall be stainless steel.

g. All window housings shall successfully pass a hydrostatic test at 5 psig for a period of two hours. Steel plates shall be substituted for the cover glasses and shall be bolted and gasketed in place for pressure test purposes. All visible leaks shall be repaired and the housing retested.

h. Each viewing window in the Metallurgical Cells shall contain a gasseal plate.

(1) The gassseal plate shall be mounted on the "hot" side of the window assembly and shall be sealed directly to the steel penetration liner.

(2) The gasmseal plate shall be 2.7 nominal density, non-browning, tempered plate glass.

(3) The gas-seal plate shall be capable of withstanding a positive pressure differential of 5 psig between the "hot" side and the "cold" side.

7. COVER GLASS

a. The "hot" side cover glass shall be of 2.7 nominal density, nonbrowning plate glass.

b. The "cold" side cover glass shali be tempered, commercial plate glass.

8. OVERAIT LIGHTT TRANSMISSION

The overall light transmission of the window assemblies, from cover glass to cover glass, shall be 30 percent or higher, based on transmission of white light, as determined by one of the following methods: 
8. OVERAIL LIGHT TRANSMISSION (Continued)

a. Response of Weston Photronic cell, corrected to eye responce by Viscor filter.

b. Tungsten light quality of International Comission on Illunination, Illuminant $A$.

c. Spectrophotometer light values at 580 millimicron wave length.

9. NON-BROWNTNG CHARACTERISTICS

a. One inch cube samples of each pour of non-browning lead glass shall be submitted to the Commission for testing prior to fabrication of the windows.

b. Samples of non-browning lead glass will be tested as follows:

(1) The Iuminous transmittance for white light shall be measured using any standard test apparatus with collimated beam spectrophotometer for 550 millimicron light before irradiation.

(2) The sample shall receive 10 million roentgen units, plus or minus 20 percent, of gamma radiation at a rate of approximately 1 million roentgens per hour. The source to be from mixed fission products cooled 30 to 90 days.

(3) After the sample has been irradiated, the light transmittance shall be determined 10 minutes after exposure using the same apparatus and the same procedures used to establish the initial values.

(4) If the ratio of transmittance, 10 minutes after exposure to the transmittance before exposure is greater than 0.95 per inch, the sample and that pour of giass shall be considered acceptable.

10. $\mathrm{OII}$

a. Oil for oil-filled windows shall be the manufacturer's normal optical oil. The oil shall be compatible with other window components to prevent clouding of the oil or fogging of the glass.

b. Oil-filled windows shall be provided with means for filling, draining and maintaining oil level without entraping air bubjles or impurities.

11. QUALITY REQUIREMUETVTS FOR GLASS

11.I GENERAI

a. Viewing windows shall incorporate the quality requirements specified herein. Imperfections shall be withir the limits specified below. 


\section{I GENERAI (Continued)}

b. Where the term central area is used herein it shall be understood to mean that portion of the view area of the window, either oval or circular in shape, the axes or diameter of which, are not less than 80 percent of the overall dimersions of the glass.

\subsection{INCLUSIONS}

a. The total projected area of all blisters, seeds, stones and cther inclusions on a polished surface, when examined visually, shall not exceed 0.001 percent of the area per inch of light path (thickness) of lead glass and shall not exceed 0.00625 percent of the area per inch of light path (thickness) of non-browring cover glass. The total number of blisters, seeds, stores and/or other inclusions shall not exceed eight per cubic irch. In the central area of the plate, the maximum number of inclusions in adjoining one inch square areas will not be considered acceptable.

b. One half of the allowable projected area of inclusions may be inclusions between .060 inches in diameter and the maximum diameter indicated below for the appropriate window size:

\begin{tabular}{|c|c|c|}
\hline \multirow[b]{2}{*}{ Area 0} & \multicolumn{2}{|c|}{$\frac{\text { Maximum Diameter of Inclusions }}{\text { (Inches) }}$} \\
\hline & Central Area & $\begin{array}{l}\text { Outside } \\
\text { Central Area }\end{array}$ \\
\hline $\begin{array}{l}\text { Iess than } 1 \frac{1}{2} \mathrm{sq} \text {. ft. } \\
1 \frac{1}{2} \text { to } 4 \mathrm{sq} \text {. ft. } \\
4 \mathrm{sq} \text {. ft. and over }\end{array}$ & $\begin{array}{l}.062 \\
.125 \\
.187\end{array}$ & $\begin{array}{l}.062 \\
.125 \\
.250\end{array}$ \\
\hline
\end{tabular}

\section{II.3 STRIAE}

Striae shall not exceed the permissible values show for Class $C$, Optical Glass in JAN-G-174(1).

\subsection{EDTES}

a. The edge surfaces of the glass shall be dull and non-reflecting. Such surfaces shall be similar in appeararce and profile to surfaces produced by acid etching, sawing or sandblastirg. When glass is to be framed, the edge contour may be deliberately ribbed or rippled to facilitate a bond between the glass and the calking or "leading" compound.

b. On edge surfaces which will not be gasketed, small chips and checks are permissible to the extent that suck imperfections do not extend into the glass more than one percent of the nominal width or length dimension and in no case more than one inch. 


\subsection{EDGES (Continued)}

c. On edge surfaces which will be gasketed, chips and checks are permissible to the extent that they do not extend into the glass more than one percent of the nominal width or length dimension and in no case more than $\frac{2}{2}$ inch.

d. Edge checks shall be smoothed so that they will not induce further breakage.

\subsection{FRAMES}

Glass shall be "leaded" into a metal frome with a high density alloy or compound as a convenient means to provide radiation shielding in the peripheral regions of the glass parts, and for ease in handling. The thickuess of the alloy shall be kept to a minimum, but shall be sufficient to aliow for the variation in the size of the glass and the frames. The thickness of the frame shall be sufficiently less than the thickness of the glass that, with allowance for unevenness and warpage of the frame, the glass may be ground to finished thickness without interference from the frame.

\subsection{POLISH}

Viewing surfaces shall be plane ground and polished. The polish in the central area shall be free frcm short finish. Small areas of "short" finish are acceptable outside the central area. Deviations from a plane surface will not be acceptable on surfaces to be gasketed except as specified in Section 11.4 above. A low reflectance type coating shall be provided on polished surfaces. The low reflectance coating shall be resistant to damage when cleaned with lint-free cloth or tissue.

12. AGGREGATTE-FIIJED WINDOWS

a. Window housings which are not to be glazed at this time, shall be the same as for glazed windows. These housings shall be suitable for removal from the cell wall and installation of high-density glass at a later date.

b. Window housings to be filled with heavy aggregate shall be cleaned on the inside and outside and given a shop coat of rust-inhibitive primer.

c. Window housings to be filled with heavy aggregate shall have a steel plate installed in the spaces at each end of the assembly which would ordinarily be occupied by the cover glasses.

\section{INSFECTION}

a. Inspection by the Commission during fabrication and testing of the glass and of the window assembly in the manufacturer's plant is required. 


\section{INSPECTION}

a. (Continued)

The Commission shall be notified at least two weeks prior to beginning each operation.

b. The method of examination and inspection of glass described below shall be adhered to so that inspection results will be uniform. The position of the glass relative to the light, the intensity of the light and the line of sight, all affect the visibility of imperfections in the glass. Requirements for visible defects shall be interpreted by examining glass in accordance with paragraph c. below when inspecting for imperfections outlined in the quality requirements specified in Section 11 above.

c. Glass shall be examined in light equivalent to that from a clear sky without sun when placed in a position similar to that of a glazed light with the inspector's eye on a level with the center of the sheet. Examination shall be made by looking through the window from a distance of approximately 36 inches, toward a brick wall or similar background, approximately 10 feet from the window, which shows essentially straight paraliel lines. 


\section{DIVISION XXII}

SPECIAL EQUIPMENT AND FURNISHINGS

\section{GENERAL}

\section{SCOPE}

This division covers laboratory and lunch room furnishings, small shop equipment, storage bins and shelving for the Fuels Recycle Pilot Plant, Building 324.

\section{SUBMISSION OF DRAWINGS AND INFORMATION}

If the Contractor proposes to supply furnishingsother than those specified in this division, he shall submit 5 copies of complete descriptive information and specifications for such items to the Commission for approval prior to purchase. The information submitted shall show the Equipment Piece Number (EPN) of the item for which the alternate is proposed, the mamufacturer's name and identification number of item specified herein, and the manufacturer's name and identification number of the proposed item. Commission approval of aiternate items is required pxior to purchase.

\section{MATHRIAIS}

\section{WORK BENCHES}

a. Work benches shall be steel framed benches with 1-3/4" laminated maple wood tops. Steel cabinets, doors and drawers shall be formed from stretcher-leveled steel furniture stock. All metal surfaces shall be finished in baked-on, light gray enamel. Wood tops shall be filled and sealed to resist grease and oil stains.

b. Work benches, identified on drawings H-3-20437 and 438 by Equipment Piece Number (EPN), shall be Lyon Metal Products, Inc.; Columbia-Hallowell division of Standard Pressed Steel Co. $\$$ Republic Steel Co., or approved equal. Iyon Catalog No. 100-H part numbers are used in the following list for more accurate designation of requirements.

EPN 1000 - 60"x28"x34" high - Iyon No. 2914

EPN 1001 - 60"x28"x34" high - Lyon No: 2844 with sliding doors No. 2860

EPN 1002 - 72"xe8"x34" high - Lyon No. 2846 with sliding doors No. 2861 EPN 1003 - $202^{\prime \prime} \times 28^{\prime \prime} \times 34^{\prime \prime}$ high - Assembly of the following parts: 
MATTERIATS (Continued)

\section{WORK BENCHES}

b. Continued

1 - Maple top Iyon No. 2715, 48"x28"

1 - Maple top Lyon No. 2717, 60"x28" (cut to 54" length)

3 - Steel base, Lyon No. 2994

8 - Drawers, Iyon No. 2788 (2 units - 4 drawers each)

1 - Cabinet, Iyon No. 2991

c. Work benches (3) EPN 324-0802-1004 will be fumished by the Commissi on but will require alteration by the Contractor for fitting in Room 211 as shown on arawing $\mathrm{H}-3-20438$.

4. STORAGE CABINETS

a. Storage cabinets shall be standard steel closed shelving with dividers where required for sizing of bins. Storage cabinets shall be finished in the manufacturer's standard light gray baked enamel. Cabinets shall be adjustable shelving except where specified otherwise.

b. Cabinets are shown on drawings H-3-20437 and H-3-20438. Cabinets shall be made up as follows:

(1) Closet shelving - EPN 1005 - 3'-0"x7'-3"xI'-0" deep, HalloweIl No. 523 .

(2) Storage bins - EPN 1006 - $3^{\prime} 0^{\prime \prime} \times 7^{\prime}-0^{\prime \prime} \times l^{\prime}-6^{\prime \prime}$ deep, without steel base and with mesh wire fronts as shown.

(3) Storage shelving - EPN $1007-3^{\circ}-0^{\prime \prime} \times 7^{\prime}-0^{\prime \prime} \times I^{\prime}-6^{\prime \prime}$ deep, without steel base, as shown.

(4) Specimen storage rack - EPN 1008 - Sized as shown on the drawing, non-adjustable type shelving (without holes in support members) and with bin-front bar.

(5) Lunch box rack - EPN 1009 - sized as shown, non-adjustable closed. type shelving, designed for floor support but attachment to wall at the top.

(6) Storage cabinet - EPN 1010, $3^{\prime}-0^{\prime \prime}$ wide $\times 7^{\prime}-1^{\prime \prime}$ high $\times 2^{\prime}-0^{\prime \prime}$ deep with 4 adjustable shelves, double swinging doors and 3 point latch but without lock, Republic No. $3716 \mathrm{~B}$. 
(7) Bin storage cabinet - EPN 1011, 3'-0" wide $x 7^{\prime \prime} 0^{\prime \prime}$ high $x 12$ " deep with bins varying in size from $3^{\prime \prime} \times 6^{\prime \prime}$ to $12^{\prime \prime} \times 9^{\prime \prime}$ plus 6 shallow drawers (approximately 120 compartments, total), Republic Automotive Bin Unit No. F-218.

(8) Wall cabinets - EPN 1017, $3^{\circ}-0^{\prime \prime} \times 4^{\prime}-0^{\prime \prime} \times 12^{\prime \prime}$ deep, for wall mounting with 3 shelves and double swinging doors and self-mounted catches.

(9) Wall cabinets - EPPN 1018, 2:6" $\times 4^{\prime \prime}-011 \times 12 "$ deep, same type as cabinets in (8) above except for size.

c. Storage cabinets shall be Republic Steel Co.; Hallowell Div. of Standard Pressed Steel Co.; Iyon Metal Prcducts Co. Inc., or approved equal.

\section{KITCHEN EQUIPMENT}

a. Wall kitchen cabinets - EPN 1019, $3^{\circ}-0^{\prime \prime}$ wide by $2^{\prime}-6^{\prime \prime}$ high by $13^{\prime \prime}$ deep, wall mounted, white baked enamel finfsh, double swinging doors, Geneva Modern Kitchens Div. of Acme Steel Co. No. 3630W, or approved equal.

b. Wall kitchen cabinets - EPN 1022, $2^{\prime}-0^{\prime \prime}$ wide by $2^{\prime}-6^{\prime \prime}$ high by $13^{\prime \prime}$ deep, same as a. above except for size, "Geneva" No. $2430 \mathrm{~W}$, or approved equal.

c. Wall kitchen cabinets - EPN 1023, 2'-0" $\times 1^{\prime}-6^{\prime \prime}$ high by $13^{\prime \prime}$ deep, same as a. above except for size, "Geneva" No. $2418 \mathrm{~W}$, or approved equal.

d. Exhaust hood cabinet - EPN 1020, shail be shs'et steel, approximately $36^{\prime \prime}$ wide by $18^{\prime \prime}$ high by $12^{\prime \prime}$ deep (minimum) with double swinging doors and white baked enamel finish. Bottom of the cabinet shall be suitable for attaching range hood and shall be adapted for passage of $16^{\prime \prime} \times 4^{\prime \prime}$ exhaust duct vertically through the center of the cabinet. Cabinet shall be "Geneva" No. 3618 W, adapted as specified above, or approved equal.

e. Range hood, EPN 1021, shall, be 36" wide by $19^{\prime \prime}$ deep (minimum), stainless steel with aluminum mesh grease filtser and 110 volt, light fixture but without fan. Range hood shall be fitted for $16^{\prime \prime} \times 4^{\prime \prime}$ top exhaust and shall be Nutone, Inc. No. 3028, or approved equal.

f. Kitchen range, EPN 1042 , shail be $27^{\prime \prime}$ white porcelain enamei range suitable for "building in" with metal base cabinets. Range shall have 4 calrod type surface units and $2 I^{\prime \prime}$ oven with front controls. Range shalI be 220 volt, General Electric Co. No. JM-6I-W, or approved equal. Renge shall be furnished complete witt chrome plated trim moulding.

8. Food warmers - EPN 1045, shall be built-in type approximately $12^{\prime \prime} \times 15^{\prime \prime} \times 8^{\prime \prime}$ to 10" high for operation wet or ary. Warmer shall be capable of heating foods within the range $100 \mathrm{~F}$ to $250 \mathrm{~F}$. Warmer shall be 230 volt, 600 


\section{MATERTALS (Continued)}

5. KITCHEN ERUIPMENI (Continued)

g. Continued

watt, with signal light and front control panel. Food warmers shall be McGraw-Edison Co. "Toastmaster" Model 15A4, or approved equal.

h. Kitchen base cabinets shall be formed with stretcher-leveled steel furniture stock and finished in white baked enamel. Cabinets shall be sized as follows:

(1) EPN-1041 - 36" wide by $25^{11}$ deep, with 2 drawers over shelved cabinet space having double swingiag doors and interior door catches. Geneva Modern Kitchens Div. Acme Steel Co. No. $36 \mathrm{C}$, or approveả equal.

(2) EPN-1043 - 24" wide by 25" deep, with single drawer over cabinet apace, otherwise same as in (1) above, Geneva No. 24C, or approved equal.

(3) EFN-1044 - 36" wide by $25^{\prime \prime}$ deep, with front panel adapted for food warmers (paragxaph go above) and with shelved storage space below having double swing doors, Geneva No. $36 \mathrm{RC}$, or approved equal.

(4) EPN-1047, 42". wide by 25" deep, sink counter cabinet without sink and drainboard, double doors below, Geneva "Sink Front" No. 42SF-FF with bottom plate, or approved equal.

(5) EPN-1049, 24" wide by 25" deep, sink counter cabinet without sink

- and drainboard, with single drawer on the right with shelved storage below and space for sink on left, Geneva No. 24 SC-FF, or approved equal.

(6) EPI-1050, $21^{\prime \prime}$ wide by $25^{\prime \prime}$ deep, single drawer at top with shelved storage space below and double swinging doors, Geneva No. 21 C, or approved equal.

\section{ILABORATORY FURNISHINGS}

\subsection{GENERAI}

a. Laboratory base and wall cabinets shall be formed from steel furniture stock not lighter than 18 gauge. Cabinets shall be finished at the factory with baiked-on, light gray enamel. 


\section{MATERIALS (Continued)}

\section{I GENERAI (Continued).'}

b. Cabinets shall be reinforced with pressed steel angles and gussets at corners to form a rigid structure. All welds exposed to view from outside the cabinet's shall be ground smooth prior to painting.

c. Glass for glazing doors shall not be lighter than double strength window glass.

d. Base cabinets shall have recessed-toe space and 1-1/4" thick tops and reagent shelves of black or charcoal gray Chemstone or Colorlith, or approved equal, except where specified otherwise on the drawings. Where maple tops and reagent shelves are specified, the material used shall be laminated hard maple $1-1 / 4^{\prime \prime}$ thick. Supports for reagent shelves shall be steel.

e. Cabinet shelves shall be full depth of cabinets. Half-depth shelves are not acceptable. Drawers shall be formed from sheet steel, not lighter than 20 gauge. Drawer guides and róllers shall be ball bearing types.

f. Laboratory furnishings are identified by Equipment Piece Number (EPN) herein and on the drawings.

\subsection{IABORATORY WAIL CABINETS}

Wall cabinets shall have 3 shelves and sliding glass doors and shall be of the following sizes:

EPN 1024, $2^{\prime}-11^{\prime \prime} \times 3^{\prime}-0^{\prime \prime} \times 12^{\prime \prime}$, Metalab No. 135-3, or approved equal. EPPN 1025, 3'-17"x3'-0"x]2", Metalab No. 147-3, or approved equal.

\subsection{IABORATORY BASE CABINETS}

Laboratory base cabinets shall be of the sizes listed below. Catalog numbers are given to identify the desired arrangement and number of drawers and cupboard spaces.

EPN 1051, 24-1/4" wide by 35-3/4" high by $22^{\prime \prime}$ deep, Metalab No. 327. EPN 1052, 24-1/4". wide by 35-3/4". high by 22". deep, Metalab No. 227. EPN 1053, 24-1/4" wide by 29-3/4" high by 22" deep, Metalab No. 821. EPN 1054, 47" wide by 29-3/4" high by $22^{\prime \prime}$ deep, Kewaunee No. 59, Lt. hand. EPN 1055, 18-1/4" wide by 29-3/4" high by $22^{\prime \prime}$ deep, Metalab No. 811. EPN 1056, 24-1/4" wide by 29-3/4" high by 22". deep, Metalab No. 221. 


\section{MATERIALS (Continued)}

\subsection{IABORATORY BASE CABINETS (Continued)}

EPN 1057, 35" wide by 29-3/4" high by 22 " deep, Metalab No. 331. EPN 1058, 47" wide by 35-3/4" high by $22^{\prime \prime}$ deep, Metalab No. 847. EPN 1059, 35" wide by 22" deep, Metalab No. ID35I.

EPN 1060, $35^{\prime \prime}$ wide by $35-3 / 4^{\prime \prime}$ high by 22 " deep, Metalab No. 637. EPN 1061, 37" wide by 22" deep, Metalab No. 1D37L.

EPN 1063, 4'-0" wide by $7^{\prime}-0^{\prime \prime}$ high by 16" deep, Metalab No. 2500. EPN 1064, 35" wide by 35-3/4" high by 22" deep, Metalab No. 137. EPN 1065, 24-1/4" wide by 22" deep, Metalab No. 1024 (between cabinets). EPPN 1066, 24-1/4" wide by $35-3 / 4 "$ high by $22^{\prime \prime}$ deep, Metalab No. 3X27. EEPN 1067, 24-1/4" wide by 35-3/4" high by 22" deep, Metalab No. 8M27. EPN 1068, $54^{\prime \prime}$ wide by $37^{\prime \prime}$ high by $22^{\prime \prime}$ deep, Metalab No. SC3126 w/o sink. EPN 1069, 35" wide by 35-3/4", high by $22^{\prime \prime}$ deep, Metalab No. AS 37. EPN 1070, 18-1/4" wide by 35-3/4" high by $22^{\prime \prime}$ deep, Metalab No. 117 . EFPN 1071, 47" wide by $35-3 / 4^{\prime \prime}$ high by $22^{\prime \prime}$ deep, Kewaunee No. 97, rt. hand. EPN 1072, 35" wide by 35-3/4" high by $22^{\prime \prime}$ deep, Metalab No. 237. EPN 1073, 35" wide by 35-3/4" high by $22^{\prime \prime}$ deep, Metalab No. 837. EPN 1074, 35". wide by 35-3/4" high by 22" deep, Metalab No. 337. EPN 1075, 35" wide by 35-3/4" high by 22" deep, Metalab No. 6M37. EPN 1076, 28-1/4" wide by 22" deep, Metalab No. 1 D28 (between cabinets). EPN 1077, 18-1/4" wide by 35-3/4" high by 22" deep, Metalab No. 817.

Iaboratory base cabinets shall be Metalab; Duralab; Kewaunee; or approved equal.

\subsection{WALK-IN HOOD - EPN 324-0802-1034 (I REQUIRED)}

a. Walk-in fume hood shall be $5^{\prime}-1^{\prime \prime}$ wide by $3^{\prime}-0^{\prime \prime}$ deep by $8^{\prime}-0^{\prime \prime}$ high, overall measurements.

b. The hood shall have a lining of type 302 stainless steel with No. 4 finish and all seams sealed by welding.

c. Service fixtures shall be provided in the hood as follows:

1 - Hot sanitary water - 85 psig.

1 - Cold" " - 85 psig.

1 - Propane - 11"WC

1 - Vacuum - 2I" Hg.

1 - Compressed air - 90 psig.

1 - Steam - 125 psig.

2 - Type 304 I stainless steel spares, 1/2" with Type 316 stainless steel valves. 


\title{
MATHRIAIS (Continued)
}

\author{
6.4 WALK-IN HOOD - EPN 324-0802-1034 (I REQUIRED) (Continued) \\ c. Continued
}

Services shall be $3 / 8^{\prime \prime}$ or $1 / 2^{\prime \prime}$ unless specified otherwise. All services shall be equipped with control valves having extension handles to permit operation from outside the hood. Services shall terminate inside the hood with a tapered stainless steel hose nipple. The hood shall have a $1-1 / 2^{\prime \prime}$ stainless steel drain in the bottom.

d. The hood shall be served by a fluorescent light fixture in the hood top, a light switch and 110 volt and 220 volt outlet receptacles shall be provided on the hood front.

e. Two sash frames formed from Type 302 stainless steel and glazed with safety plate glass shall provide access to the hood. Sash shall seal the front opening of the hood water tight when closed.

f. The hood shall be equipped with a 12" diameter exhaust outlet through the top.

g. The walk-in hood shall be Duralab Equipment Corp. Model HWLAF60s, or approved equal.

\subsection{HOOD BASE CABINETS - EPN 324-0802-1062 (8 REQUIRED)}

Hood base cabinets shall be $47^{\prime \prime}$ wide by $22^{\prime \prime}$ deep by $35-3 / 4 "$ high. Cabinets shall be all steel construction with remote control mounting panel at the top and cupboard space below. Cupboard space shall have one full depth steel shelf and shall be served by double swinging doors. Cabinets shall be finished with baked-on light gray enamel. Hood base cabinets shall be Metalab Equipment Co. No. FC47, or approved equal.

\section{SINKS}

7.I IABORATORY SINKS - EPN 324-0802-1080

Laboratory sinks shall be single bowl seamless drawn, 18 gauge stainless steel with all corners coved. Interior of bowl shall be No. 4 finish and underside shall be coated with a sound deadening material. Sinks shall be 20-1/8" $\times 16^{11 \times 10^{\prime \prime}}$ deep with $1-1 / 2^{\prime \prime}$ drain. Sinks shall be Metalab Equipment Co. No. $323 I-S$, or approved equal.

\subsection{KITCHEN SINK - EPN 324-0802-1081}

Kitchen sink shall be double bowl, seamless drawn, 18 gauge stainless steel with all corners coved. Bowls and ledges shall be No. 4 finish. Back rim 


\section{MATERIAIS (Continued)}

7.2 KITCHEN SINK - EPN 324-0802-1081 (Continued̄)

shall have 2 cutouts 8 " $0 . c$. stradding center line. Sink shall be $33^{\prime \prime} \times 22^{\prime \prime} x$ 7-3/8" deep with 1-1/2". drains. Sink shall be Lyons-Stainless Products

"Iyoncraft" No. 2080, or approved equal.

8. TOOL STANDS - EPN 324-0802-1078 (2 REQUIRED)

Tool stands shall be 18"x24" $\times 32$ " high, all-steel construction with tray type tops and two tray shelves.- Tool stands shall have light gray baked ënamel finish but shall not have casters. Tool stands shall be Hallowell Division of Standard Pressed Steel Co. Model 430-1824, or approved equal.

9. LUNCH ROOM FURNITURE AND COUNTER TOPS

a. Iunch room tables shall be steel, double pedestal tables $29^{\prime \prime}$ high with plastic covered tops. Pedestal feet shall be equipped with adjustable floor glides and kick plates. Table tops shall be plywood with melamine plastic surfacing, I" thick overall. Edges shall be reinforced with a $3^{\prime \prime}$ wide strip of plywood to bring edge thickness to $1-1 / 2^{\prime \prime}$. Tops and edges. of table tops shall be surfaced with 1/16" thick melamine plastic, General Electric Co. "Textolite" pattern TX-4815 Aqua Twilight, or approved equal, to match lunch room counter tops. Tables shail be Royal Metal Kf5. Co. No. 968, or approved equal. Eight tables are required..

b. Iunch room counter tops and 6" high splashback shall be the same material o.s used for table tops except. top shall be 3/4" thick, reinforced to $1-1 / 2^{\prime \prime}$ at edges and self-edged with surfacing material. Stainless steel edge molding shall be provided around splashback with $1 / 2^{\prime \prime}$. stainless cove molding at joint with counter top.

c. Iunch room chairs shall be $18^{\text {"1 }}$ seat height, one piece, molded glass fiber seat and back with round, chrome plated, tubular steel legs. Seats and backs shall be salmon color. Iegs shall be fitted with non-marring floor glides. Chairs shall be Brunswick-Balke-Collander Co. "Stacking Chair" in "CN-Salmon" color, or approved equal. Sixty-four chairs are required.

10. IOCKERS AND BENCHES

a. Iockers in the Change Room shown on drawing H-3-20163 numbered I to 83 shall be $12^{\prime \prime} \times 15^{\prime \prime} \times 72^{\prime \prime}$ with hat shelf, 3 coat hooks and padlock hasp for private locks. Iockers shall have flat tops, louvered doors and shall be finished in light gray baked-on enamel. Lockers shall bear number plates to correspond with numbers shown on the drawings. Lockers shall 
MATERIALS (Continued)

10. LOCKERS AND BENCHES

a. Continued

be single row, single tier, without legs for curb mounting, Republic Steel Corp. Type SS, No. 50-gray; Lyon Metal Products, Inc. No. 5032 (catalog No. 100-H); Penco Div. Alan Wood Steel Co: Series 6100, 10. 704 Warm Gray, or approved equal.

b. Box lockers shall be $12^{\prime \prime} \times 15^{\prime \prime} \times 12^{\prime \prime}, 6$ tiers high in 5 sections for a total of 30 lockers. Lockers shall be similar in construction and finish to lockers in a. above. Iockers shall have spring latch and shall be fitted. for private padlocks. Locker units shall be without legs for curb mounting. Iockers shall be:

Republic Steel Corp. Type S, No. 50 Gray; Lyon Metal Products, Inc., No. 5342, Lyon Gray; Penco Div. Alan Wood Steel Co. Series 6300, No. 704 Warm Gray

c. All lockers specified in paragraphs $a$. and $b$. above shall be products of one manufacturer.

d. Locker benches shall have steel pedestals with laminated birch or maple tops $9-1 / 2^{\prime \prime}$ wide and 1-1/4" minimum thickness. Benches shall be $17-1 / 2^{\prime \prime}$ or 18" high. Tops shall be filled, sealed and finished with clear lacquer or varnish. Locker benches shall be of the lengths shown on the drawings, with benches longer than 9 feet having 3 pedestals. Locker benches shall be Republic Steel Corp., Iyon Metal Products, Inc., Penco Div. of Alan Wood Steel Co., or approved equal.

\section{TOIIET COMPARMMENTS AND BAFFLES}

a. Toilet compartments and urinal baffles shall be galvanized, bonderized steel with chrome plated hardware. Partitions and baffles shall be finished in dark blue baked-on enamel. Urinal baffles shall have full depth flange for mounting on plaster wall. Toilet compartments shall be flush top with floor support pilasters. All panels shall be not less than I" thick with 1-1/4" thick pilasters and shall be filled with sound deadening core material. Color shall match color No. 15080 in Federal Standard 595. Compartments shall have roll paper holder on wall and coat hook on door.

b. Toilet compartments shall be:

Sanymetal Products Co. Inc. "Normandie" style, No. 25 Blue; 


\section{MATERIAIS (Continued)}

17. TOIIET COMPARTMENTSS AND BAFFIES

b. Continued

Robart Partitions, Inc. Type A, No. 11564 BIue;

Milwaukee Stamping Co. "Ferrometal" Type FT, dark blue; or approved equal.

c. Urinal baffles shall be $24^{\prime \prime} \times 42^{\prime \prime}$ and shall be:

Sanymetal Products Co. Inc. Type A, No. 25 BIue;

Robart Partitions, Inc. Type FS, No. 11564 Blue;

Milwaukee Stamping Co. "Ferrometal" Type 2, dark blue; or approved equal.

12. FIRE HOSE CABINETS

a. Fire hose cabinets mounted in-the-wall shall conform to Hanford Standard AC-1-30, with the following exceptions:

(1) 75 feet of 1-1/2" Iinen hose shall be furnished except where other lengths are specified on the drawings.

(2) Cabinet shall have doors glazed with double strength glass.

(3) Cabinets in Area 2 shall be painted to match adjacent walls.

(4) Cabinets shall have one 5 lb. dry chemical extinguisher.

(5) Cabinets shall have $2-1 / 2^{\prime \prime}$ return face trim.

Allen Mfg. Co. "Shallowall" cabinet Fig. No. 215 AT is an example of the type equipment required.

b. Fire hose cabinets, other than in Area 2, shall be the same as specified in paragraph a. above except they shall be designed for surface mounting. Allen Mfg. Co. "Allenco" cabinet Fig. No. $215 \mathrm{AW}$, is an example of the type required.

\section{EQUIPMENT ANCHORS}

Anchors to be used in fastening machines and small shop equipment in place shall be cone type with threaded bottom unit, Rawlplug Co. Inc. "Threaded Multi-Calks", or approved equal. 
MATERIALS (Continued)

\section{MIRRCRS}

a. Mirrors shall te of the size shown on the drawings. They shall be made from polished plate glass with silver applied to one side. Silver film shall be protected by electrolytically plating copper in a solid film over the silver. Copper plate shall be protected with a coat of hard paint. Mirror frames shall be of stainless steel or chrome plated steel. Mirrors shall be Charles Parker Co. No. 3020 , or approved Equal.

b. Mirrors over lavatories shall have a $5 " \mathrm{x} 16$ " stainless steel shelf attachsd at the bottom. Other than shelf, lavatory mirrors shall conform :0 the requirements stated in paragraph a. above. Mirror with sheif shall be Charles Parker Co. No. 53020, or approved equal.

\section{PAPER TOWEL DISPENSERS}

Paper towel Jispensers shall be "Westowel Cabinets" with mirror front as manufactured by the West Disinfecting Co., or approved equal. Color: White.

\section{WASTE RECEPTACLES}

a. Two waste receptasies shall be provided for the men's change room. Receptacles shall have swing top and gray baked enamel finish on the exterior. Inner container shall be galvanized steel of approximately 27 gallons capacity . Receptacles shall be approximately 16" x 16" x 36" high. Receptacles shall be West Disinfecting Co. No. 130, or approvez equal.

b. Two metal wastehaskets, one per lavatory, shall be provided for the women's rest room. Size: approximately 12" x 12" x 15". Color: gray.

c. One waste receptacle shall be provided in women's rest room for soiled sanitary napkins. Receptacle shall be approximately 11 inches high by $7-5 / 8$ inches wide by $3-3 / 4$ inches deep and shall be U. S. Sanitary Specialties Corporation No. 198 "Useptican", or approved equal.

d. Waste receptacie for the lunch rocm shall be approximately 15" diameter by $36^{\prime \prime}$ high and finished in white baked enamel with chrome plated push-open top and trim. The receptacle shall have a galvanized inner container of approximately 15 gallons capacity. Lunch room waste recfptacle shall be West Disinfecting Co. "Round Top Receptacle" Style IJo. 1536, or approved equal.

\section{SANITARY NAPKIN DISPENSER}

A sanitary napkin dispenser shall be provided for the women's rest room. Dispenser shall be West Disinfecting Company Napkin Dispenser, or approved equal. Color: White. 
18. IAUNDEY BAG HOIDERS

Laundry hag holders shall be fabricated of carbon steel tubing in accordance with Hanford Standard AC-1-2l. Holders shall be cleaned of all weld spatter, sandblasted and painted with one coat steel primer and two coats gray enamel.

19. CHALKBOARD AND BULLETIN BOARD

a. Chalkboard shall be Son-nel Mfg. Co. "Calslate" chalkboard, or approved equal, of the size shown on the drawings. Color: Dull blue. Chalkboard shall be furnished with extruded aluminum frame and aluminum chalk and eraser tray.

b. Bulletin board shall be Son-nel Mfg. Co. No. B-10 Bulletin cork board, or approved equal, $1 / 4$ " thick with extruded aluminum frame and chalk and eraser tray to match chalkboard. Color of corkboard: wheat tan.

c. Chalkboard and bulletin board shall have common frame.

20. PROJECTICN SCREEN

Projection sereen shall be a Radiant model W 70" x 70" All Purpose Wall Projection Screen, or approved equal.

\section{FIRE BLAIIKET}

Fire blanket for laboratory shall be approximately $62^{\prime \prime} \times 82^{\prime \prime}$ of flame proofed wool enclosed in a metal case with rope pull. Case shall be designed for wall mounting. Fire blanket shall be Mine Safety Appliance No. FA-10227, or approved equal.

\section{VINYL TAPE}

Tape for sealing the right angle joint between laboratory table tops and pipe space covers or walls shall be a $2^{\prime \prime}$ wide, black, polyvinyl chloride tape with adhesive backing. Tape shall be 0.010 inches thick and shall be Permacel No. 306, or approved equal.

23. CIGARETTE URNS

Cigarette urns shall be floor standing, cylindrical, steel sand urns with steel or aluminum tray in the top. Urns shall be $10^{\prime \prime}$ in diameter and approximately 19" high. Lawrence Metal Products No. 24-X or No. 32-A are examples of available products meeting these requirements.

24. BUIIDING AND ROCM IDENTIFICATION SIGNS

a. Building sign for exterior building identification shall be black enamel sheet aluminum letters 5 " high, Spencer Industries, Philadelphia, Pa., "Kabel Design", or approved equal, with P-8 projected mounting. Sign shall consist of the building number digits, 324 . Digits shall be $1 / 2$ " deep, $7 / 8$ " stroke width with 1 " long aluminum spacer sleeves. 


\section{MATERIAIS (Continued)}

b. Room identification signs shall be Spencer Industries, Philadelphia, $\mathrm{Pa}$., Bakelite Signs, or approved equal, black face with white gothic style letters and numerals, minimum size of sign $2^{\prime \prime} \times 6^{\prime \prime}$. Lettering and numerals shall be specified in this division.

\section{WORKMANSHIP}

\section{INSTALLATION OF CABINETS AND FURNITURE}

a. Laboratory and kitchen cabinets, shelving and storage bins shall be located as shown on the drawings. Items not specifically located on the drawings shall be located as directed by the Commission.

b. Metal furnishings shall have all burrs, sharp points and edges removed.

c. Lockers and locker benches shall be anchored to the floor with bolt anchors. Chalkboard, projection screen, mirrors and other wall-mounted furnishings shall not be hung with cord or wire but shall be rigidly secured to the mounting surface with mechanical fasteners.

d. Lunch box rack shall be anchored to the wall near the top of the rack to prevent overturning.

e. Where laboratory table tops abut vertical surfaces such as walls, pipe space covers and reagent shelf supports the right angle joint shall be covered with 2 " wide PVC tape. Tape shall lap on the vertical surface one inch. Tape shall be applied in straight lines and corners shall be lapped 2 inches.

f. Metal closure strips shall be installed where shown on the drawings. Closure strips shall be attached to adjacent cabinets with sheet metal screws and shall be painted to match the cabinets.

\section{MOUNTING BUIIDING AND ROOM IDENTIFICATION SIGNS}

a. Building identification sign consisting of the digits " 324 " shall be mounted using Spencer Industries P- 8 projected mounting devices or approved equal. Numerals shall be located as shown on drawing H-320186.

b. Each rocm in the administration and laboratory areas shall be identified by a room number sign or a legend. Rooms in the other parts of the building will not require signs except as noted below.

c. Doors No. 104, 105, 108, 204, 248, 302, 320 \& 327, shall have emergency exit signs per Hanford Standard AC-3-2, Type II, except that signs shall be mounted $5^{\prime}-6^{\prime \prime}$ above the floor.

d. Room number signs shall be mounted to the right of the respective doors five feet, six inches (5' 6") above the floor. Fastening shall be by No. $4-40$ binding head, self-tapping steel machine screws, 2 per sign. Rocm identification signs shall be mounted on the door 


\section{WORKMANSHIP (Continued)}

26. MOUIFING BUIIDING AND ROOM IDENTIFICATION SIGNS

d. Continued

five feet, six inches $\left(5^{\prime} 6^{\prime \prime}\right)$ above the floor with self-tapping steel machine screws for metal doors.

Legend for Sign

LUNCH ROOM

MEN

WOMEN

MENSS CHANIGE ROOM

STAIRS

CLEAN CLOTHES STORAGE

SOIIED CLOTHES STORAGE

JANITOR

CONTROL ROOM

VENIIIATION EQUIPMENT ROOM

CHEMICAI MAKEUP

CHEMICAL STORAGE

SERVICE TUNNEI

FILTER ROOM

ROOM FIIIEERS

CEII, FILTEERS

COLD CANYON EXHAUST FAN ROOM

FIRE WATERR VALVE

PERSONNEEI DECONTAMINATION
Iocation of Sign

(Door numbers)

Doors $142 \& 143$

217

246

$117,118,128,133,152 \& 161$ $14,124,147,148,160,184$, $205,222,234,249,255,303$, $305,321 \& 327$ 146

$149 \& 150$

$130,153 \& 212$

319

303

317

315

$16 \& 17$

$3,4,5,311,312 \& 328$

$10 \& 13$

$6 \& 9$

$310 \& 313$

186

15

27. SPECIAL EQUIPMENT

a. Certain items of tanks, hoods and small shop equipment will be furnished by $=\vdots=$ Commission to the Contractor for installation, as listed in the Special Conditions.

b. All items of floor-standing equipment shall be fastened in place with bolts and bolt anchors except where shown otherwise on the drawings.

c. Cigarette urns shall be located as follows:

(1) One in Room 112 .

(2) Two in Room 123.

(3) One adjacent to each door in Room 117. 


\section{DIVISION XXIII}

ROADS AND PAVIITG

GENERAI

1. $\mathrm{SCOPE}$

This division covers the grading and surfacing of roadways and the parking lot as shown on drawing $\mathrm{H}-3-20152$, for the Fuels Recycle Pilot Plant, Building 324.

2. REFERENCED STANDARDS AND SPECIFICATIONS

The standards and specifications listed below form a part of this specification to the extent indicated by subsequent references.

2.1 HAIEORD STANDARD SPECIFICATIONS

HWS-6131-S, Rev. 1, Hot Laid Asphaltic Concrete Pavemuent

HWS-6134-s, Grading and Drainage For Roads

HWS-6136-S, One-Course Crushed Gravel Surfacing

\section{MATERTAIS}

3. ASPHAITIC CONCRETE PAVEMENT

Materials for base course, leveling course and asphalitic concrete for roadways, parking lot, driveways and ramp shall conform to the requirements specified in Hanford Standard Specification HWS-6131-mS. Prime coat of "cutback" asphalt will not be required for, the work csovered by this division.

4. GRAVEL SURFACING

Gravel and binder for the wearing course of the gravesl surfaced roadway east of the building shall conform to the requirementss stated in Hanford. Standard Specification HWS-6136-S.

5. CULVERT PIPE

Corrugated metal culvert pipe shall conform to the reequirements stated in Hanford Standard Specification HWS-6134-S. 


\section{WORKMANSHIP}

6. GRADING AND DRAINAGE

a. Earth grading for roadways, parking lot, driveways, and ramps shall be done in accordance with the requirements stated in Hanford standard Specification HWS-6134-S.

b. Culvert pipe shall be installed as specified in Hanford standard Specification HWS-6134-S.

7. ASPHALTIC CONCRETE PAVING

a. The base course and leveling course shall be constructed on the earth subgrade prepared as specified in section 6 above.

b. The asphaltic concrete shall be iconstructed as specified in Hanford Standard Specification HWS-6131-S. Prime coat under asphaltic concrete will not be required.

c. The crown in the asphalt surfacing shown in the typical roadway section on drawing $\mathrm{H}-3-20152$ shall be moved to the south edge where the roadway parallels the loading dock at the rear of the building. Drainage shall be away from the building and across the road.

8. GRAVEL SURFACED ROADS

a. The earth subgrade for the gravel surfaced road, east of the building, shall be prepared as specified in section 6 above.

b. The base course for the roadway shall be constructed using the materials and the methods specified in Section 3 of Hanford standard Specification HWS-6131-S.

c. A single course gravel surfacing shall be laid on the roadway in accordance with the requirements stated in Hanford Standard Specification HWS-6136-S. 
DIVISION XXIV

EXHAUST STACK

GENERAL

1. SCOPE

This division covers the design and construction of the reinforced concrete exhaust ventilation stack, Building 324-B, as indicated on drawing $\mathrm{H}-3-20621$, for the Fuels Recycle Pilot Plant, Building 324.

2. REFERENCED STANDARDS AND SPECIFICATIONS

The standards and specifications listed below form a part of this specification to the extent indicated by subsequent references.

2.1 HANFORD STANDARDS

AC-2-6, Rev. I, Steel Ladder Rung for Concrete Walls

\subsection{AMERICAN STANDARDS ASSOCIATION}

ASA C 5.1-1959 Code for Protection Against Lightning for Persons

ASA C 5.2-1959 Code for Protection Against Lightning for Buildings and Miscellaneous Property

2.3 AMERICAN CONCRETE INSTITUTE

ACI 505-54 Specification for Design and Construction of Reinforced Concrete Chimneys

2.4 INIERNATIONAL CONFERENCE OF BUIIDING OFFICIALS

Uniform Building Code, 1961 Edition

\subsection{AMERICAN SOCIETY FOR TESTING MATERIALS}

ASTM A123-59 Specification for Zine (Hot-Galvanized) Coatings on Products Fabricated from Rolled, Pressed and Forged Steel Shapes, Plates, Bars and Strips

ASTM A.312-61T Specification for Seamless and Welded Austenitic Stainless Steel Pipe 
a. The Contractor shall prepare and submit, for comment or approval of the Commission complete design drawings, diagrams, calculations and construction specifications for a reinforced concrete stack and foundation meeting the requirements specified herein and the requirements shown on Drawing No. H-3-20621. Design drawings and specifications shall be submitted in accordance with the requirements stated in the Special Conditions.

b. Plans and specifications shall be prepared under the direction of, and stamped by a licensed professional civil or structural engineer.

4. STANDARDS FOR DESIGN

AlI materials, design and construction shall be in accordance with the following codes and standard's:

a. Design shall conform to the requirements of ACI 505.

b. The forming, placing, finishing and curing of concrete shall be covered in the construction specifications to be submitted in accordance with the Special Conditions.

c. Design for earthquake shall conform to ACI 505 and section 2312 and Appendix section 2312 of the Uniform Building Code for Zone 2 requirements.

d. Design for wind pressure shall conform to ACI 505. Wind pressure shall be taken as $100 \mathrm{mph}$ at $30^{\prime}$ above grade in accordance with Table 1 of ACI 505.

e. The allowable design soil bearing pressure shall not exceed 4000 lbs. per sq. ft.

f. Iightning protection shall conform to ASA C 5.1 and C 5.2 and the following:

(1) Conductors above grade shall be 4/0 AWG stranded copper wire ( $98 \%$ conductivity). Conductors below grade shall be $5 / 8$ " extra galvanized steel.

(2) Conductors shall be of unbroken lengths. Connections shall be made by the thermite fusion process.

(3) Conductors shall be connected to $3 / 4^{\prime \prime} \times 8^{\prime}$ galvanized ground rods. Ground rods shall be driven at least $7^{\prime}$ below the bottom of the stack footing. 
4. STAMDARDS FOR DESTGN (Continued)

(4) Conductors shall be connected to the ground rod by the thermite fusion process.

(5) Joints in the conductors and connection to the ground rods shall be completely covered with asphaltic paint and friction tape for at least 6" from the joint.in each direction.

(6) Conductors and ground rods shall be located as indicated on the building grounding plan, drawing H-3-20295.

(7) Conductors (leads) shall be provided for connecting the ground grid from the 324 Building to the grounding system provided for the stack.

g. Stack lighting shall consist of four obstruction warning lights, 90 degrees apart in a horizontal plane not more than 10 feet below the top of the stack.

(1) Lighis shall be double fixture, weatherproof, Crouse-Hinds No. $43950 \mathrm{~A}$, Type VAW marker lights, or approved equal.

(2) Iamps shall be 100 watt, 115 volt A-C, No. A-2l clear, with red cover glass.

(3) Light switch shall be a photo-electric cell, General Electric Co. No. C42OGOI3, or approved equal.

(4) Thompson Disconnect Hangers, or approved equal shall be used, to permit servicing the lights from the ground.

(5) Obstruction lights shall be connected to Circuit No. 5, Panel "U", show on drawing No. $\mathrm{H}=3-20377$.

(6) Conduit for lighting circuits shall be rigid, galvanized steel.

(7) Wire for lighting circuits shall be NO. I0 THW.

h. The breeching shall be constructed of steel lined concrete in such a manner to make an airtight connection between the stack and the concrete duct. The breeching shall have a flexible expansion joint that will prevent earthquake stresses from transmitting from the stack to the underground ducts.

\section{OPERATTNE CONDITIONS}

a. For design purposes, the atmosphere temperature range at the site shall 
a. (continued)

be taken as minus $20 \mathrm{~F}$ to $110 \mathrm{~F}$.

b. It is anticipated that the maximum temperature of gases inside the stack at the breeching will not be greater than $120 \mathrm{~F}$.

6. STACK ADPTRTIAANCES

5. Exierior Iadder shall be as show on drawing H-3-2062l. An interior ladder will not be required. Ladder mungs shall be galvanized per ASTM AI23.

b. A stack access door, approximately $30^{\prime \prime} \times 36^{\prime \prime}$ shall be located opposite the breeching with bottom of door one foot above earth grade. Door and Irsme may be cast iron or fabricated steel. The door shall be fitted with lugs or hasp suitable for padlocking from the outside.

c. The stack cap ring shall be cast iron or alloy steel as specified in ACI 505 .

d. Stock spray rings shall be Type 304-I seamless or welded stainless steel pipe conforming to ASTM A312.' Spray supply riser is not required.

\section{SMACK FIVISH}

a. Exterior formed surfaces shall have all fins, joint marks, bulges, projections and loose material removed, and defective concrete, form-tie holes, air bubble holes, surface pits, holes from defective forms, nailhead holes and similar surface defects repaired.

b. Interior formed surfaces shall have all projections removed. Holes, pits, and all other types of depressions shall be filled with a mixture of litex resin and finely ground hydraulic cement. Sherwin-Williams "Iroxon"; Carboline Co. \#3340 Surfacer, or approved equal, shall be used for interior repair prior to painting.

\section{PAINTING}

a. AII interior surfaces of the stack and breeching which will come in contact, wi.th the exhaust gases shall be coated with a chemical resistant, sir curing, Vinyl coating system capable of withstanding the following conditions without damage greater than slight discoloration:

(1) Maximum temperature: $120 \mathrm{~F}$ dry. 
a. (Continued)

(2) Submergence in $30 \%$ nitric acid or $50 \%$ sodium hydroxide for 30 days.

(3) The dry coating system shall not support combustion and shall be self-extinguishing when individual strips are subjected to and removed from a flame.

b. E. I. duPont Co. "Imlax" vinyl coating system 6 mil (0.006 inches) thickness; Amercoat Corp. "Amercoat 55" vinyl coating system 6 miI ( 0.006 inches) thickness and Carboline Co. "Polyclad No. 955" system, $6 \mathrm{miI}(0.006$ inches) are exampies of coating systems which are acceptable for the service intended. Thicknesses are for the finished dry film including 2 seal coats.

c. Exterior of the access door and its frame, the stack cap ring and the flange covering the monitoring hole shall be painted the same as the metal of the breeching specified in paragraph a. above.

d. The galvanized steel ladder rungs and the stainless steel spray piping are not to be painted.

e. Exterior finish paint shall be color No. 16329 per Federal Standard 595. Irterior finish shall be either white or the same as exterior color. 


\section{APPENDIX A \\ PROCESS AREA VENTILATION \\ ACCEPTANCE TEST PROCEDURE}

1. SUPPLY FANS

a. Test Procedure shall not be performed until system balancing is complete.

b. With the normal ventilation system running, record the following supply fan data: ‥m

\begin{tabular}{|c|c|c|c|c|c|c|c|c|c|}
\hline Fan & Motor & Speed & Bearing & Vibration & Inlet & Diff S.P. & & \multicolumn{2}{|c|}{ Corr. Values (3) } \\
\hline EPN & Arip. & $\mathrm{RPM}$ & Temp (1) & Displnt. (2) & Temp & In。 w.g. & $\mathrm{CFM}$ & $\mathrm{S}_{0} \mathrm{P}_{0}$ & $\mathrm{CFM}$ \\
\hline 901 & & & & & & 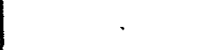 & & & \\
\hline 1902 & & & & & & & & & \\
\hline
\end{tabular}

(1) Normal bearing running temperature should be approximately $150 \mathrm{~F}$.

(2) The peak-to-peak amplitude of vibration of the installed fan, when measured on the shaft or bearing caps in the horizontal and vertical planes at the rated flow, static pressure, and speed, shall not exceed 0.002 inches. Displacement may be measured by an International Research and Development Analyzer or similar portable instrument.

(3) Correct the static pressure and flow to $70 \mathrm{~F}$ and 29.92" Hg.

c. With one supply fan and half of the exhaust fans running, check the supply fan performance against the submitted fan performance curve by regulating the flow through the radial inlet damper. (Vary the exhaust flows as required to get supply fan data). A minimum of four points should be plotted. Correct the static pressure and flow to $70 \mathrm{~F}$ and $29.92 " \mathrm{Hg}$. Return damper settings to normal.

\begin{tabular}{|c|c|c|c|c|c|c|c|c|}
\hline ' & & & asure & alues & & & & \\
\hline Fan & & & & & & & & \\
\hline EPN & $S_{0} P_{0}$ & CFM & S.P. & CFM & $S_{0} P_{0}$ & $\mathrm{CFM}$ & $\mathrm{S}_{0} \mathrm{P}_{0}$ & $\mathrm{CFM}$ \\
\hline 901 & & & & & & & & \\
\hline 902 & & & & & & & & \\
\hline
\end{tabular}




\begin{tabular}{|c|c|c|c|c|c|c|c|c|}
\hline \multirow{3}{*}{\begin{tabular}{|l} 
Fan \\
EPN \\
\end{tabular}} & \multicolumn{6}{|c|}{ Corrected Values } & \multirow{2}{*}{\multicolumn{2}{|c|}{ (4) }} \\
\hline & \multicolumn{2}{|c|}{ (1) } & \multicolumn{2}{|c|}{ (2) } & \multicolumn{2}{|c|}{ (3) } & & \\
\hline & $S_{0} P_{0}$ & CFM & S.P. & CFM & $S_{0} P_{0}$ & $\mathrm{CFM}$ & $S_{0} P_{0}$ & CFM \\
\hline 901 & & & & & & & & \\
\hline 902 & & & & & & & & \\
\hline
\end{tabular}

Describe any defects or note acceptance

d. With one suppiy f'an ard half the exhaust fans running, test the discharge damper of the other for leak tightness. Leakage shall not exceed $5 \%$ of the rated flow at the rated differential pressure. Correct the fliow to $70 \mathrm{~F}$ and $29.92 \mathrm{l} \mathrm{Hg}$.

\begin{tabular}{|l|c|c|c|}
\hline Fan & Rated Flow & \multicolumn{2}{|c|}{ Discharge Damper Leakage } \\
\cline { 3 - 4 } E.P.N. $_{0} \mathrm{~N}_{\circ}$ & CFM & Measured & Corrected \\
\hline 901 & & & \\
\hline & & & \\
\hline
\end{tabular}

Describe any defects or note acceptance

e. Adjust the supply fan radial inlet damper stops so that the damper operators are restrained one-half way between the normal operating ard the ciosed positions.

\section{SUPPLY UNIT ATR WASHERS}

With the rormal ventilation system running, recond the following temperatures and caiculate the saturation efficiency of each air washer. It should not be less than $95 \%$ when the unit is operating normally. Record the pressure drop across the air washer which should not exceed 0.45 inches w.g.. Correct the static pressure and flow to $70 \mathrm{~F}$ and $29.92^{\prime \prime} \mathrm{Hg}$. Note spray coverage of pads and any Ileaks.

$t_{1}$ - dry buil temperature upstream of washer

$t_{2}-d r y$ bulb temperature downstream of washem

$t_{3}$ - wet bulb temperature

$$
\begin{aligned}
& \% \text { sat. eff }= \\
& \frac{t_{1}-t_{2}}{t_{1}-t_{3}} \times 100
\end{aligned}
$$




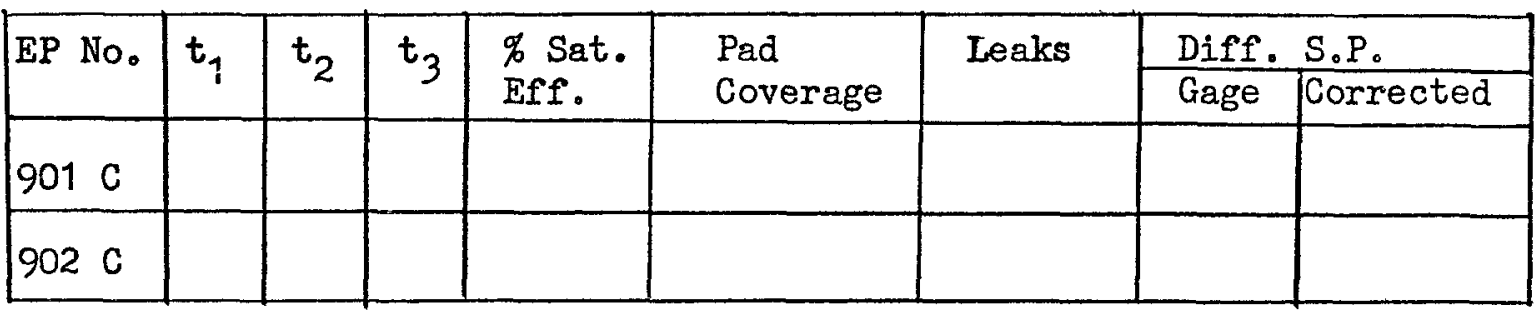

Describe any defects or note acceptance

\section{SUPPLY UNIT AIR FILTERS}

With the normal ventilation system running, record the pressure drop across the filters. With clean media a pressure drop greater than 0.20 inch W.g. shall not be acceptable. Correct the static pressure to $70 \mathrm{~F}$ and $29.92^{\prime \prime} \mathrm{Hg}$. Verify that filter controls, trips, and drive work satisfactorily.

\begin{tabular}{|c|c|c|c|c|}
\hline EP No. & Measured Diff. S.P. & Air Temp & Corrected S.P. & Controls\&Drive \\
\hline 901 D & & & & \\
\hline 902 D & & & & \\
\hline
\end{tabular}

Describe any defects or note acceptance

4. STEAM SUPPLY UNIT HEATING COIIS AND ZONE REHEAT COIIS

a. Each coil section shall be tested separately to avoid excessive building temperature.

b. The control valve for the coil being tested shall be open and full steam flow shall be on the coil.

c. Record the following data:

(1) With the entire normal ventilation system running, and after the temperatures have stabilized, measure and record the dry bulb temperature of air entering and leaving the coil and verify that the heating capacity is at least equal to the manufacturer's rating. 


\section{4. (CONTINUED)}

c. (continued)

(2) Measure and record the static pressure drop across each coil and air flow and compare with the manufacturer's rated values.

(3) Verify that all traps function properly.

\begin{tabular}{|c|c|c|c|c|c|c|c|c|}
\hline \multirow{3}{*}{$\ddot{\text { EPN }}$} & \multicolumn{2}{|c|}{ Rated } & \multicolumn{6}{|c|}{ Measured } \\
\hline & \multirow{2}{*}{$\begin{array}{l}\mathrm{Cap}_{\circ} \\
\mathrm{BTU} / \mathrm{hr}\end{array}$} & \multirow{2}{*}{$\begin{array}{l}\text { Diff. } \\
\text { S.P. }\end{array}$} & \multirow{2}{*}{$\begin{array}{r}\text { Diff. S.P. } \\
\text { Meas. Corr. } \\
\end{array}$} & \multirow{2}{*}{$\begin{array}{l}\text { Ent. } \\
\text { Air }\end{array}$} & \multirow{2}{*}{$\begin{array}{l}\text { Lig. }{ }^{\circ}{ }_{F} \\
\text { Air }\end{array}$} & $\overline{C F M}$ & \multirow{2}{*}{$\begin{array}{l}\text { Capo } \\
\text { BTU/hr }\end{array}$} & \multirow[b]{2}{*}{ Traps } \\
\hline & & & & & & Meas. Corr & & \\
\hline \multicolumn{9}{|c|}{$901 \mathrm{E}$} \\
\hline \multicolumn{9}{|c|}{901 B } \\
\hline \multicolumn{9}{|c|}{$902 \mathrm{E}$} \\
\hline \multicolumn{9}{|c|}{$902 \mathrm{~B}$} \\
\hline \multicolumn{9}{|l|}{909} \\
\hline \multicolumn{9}{|l|}{910} \\
\hline \multicolumn{9}{|l|}{911} \\
\hline \multicolumn{9}{|l|}{912} \\
\hline \multicolumn{9}{|l|}{913} \\
\hline \multicolumn{9}{|l|}{914} \\
\hline \multicolumn{9}{|l|}{915} \\
\hline \multicolumn{9}{|l|}{916} \\
\hline \multicolumn{9}{|l|}{917} \\
\hline \multicolumn{9}{|l|}{918} \\
\hline 919 & & & & & & & & \\
\hline
\end{tabular}

Describe any defects or note acceptance 
5. ELECTRIC ZONE REHEAT ELEMENTS E.P.N.920

a. Thermostat shall be calling for heat.

b. Record the following data:

(1) After the temperatures have stabilized, record the dry bulb temperature of the air entering and leaving the heating elements and verify that the heating capacity is at least equal to the manufacturer's rating.

(2) Measure and record the static pressure drop across the heating elements and the air flow and compare with the manufacturer's values. Correct the static pressure and flow to $70 \mathrm{~F}$ and $29.92^{\prime \prime} \mathrm{Hg}$.

\begin{tabular}{|c|c|c|c|c|c|c|c|c|c|}
\hline \multirow{3}{*}{ EPN } & \multicolumn{2}{|c|}{ Rated } & \multicolumn{6}{|c|}{ Measured } & \multirow{3}{*}{$\begin{array}{l}\text { Cap. } \\
\mathrm{BTU} / \mathrm{hr}\end{array}$} \\
\hline & \multirow{2}{*}{$\begin{array}{l}\text { Cap. } \\
\text { BTU/hr }\end{array}$} & \multirow{2}{*}{$\begin{array}{l}\text { Diff. } \\
\text { S.P. }\end{array}$} & \multicolumn{2}{|c|}{ Diff. S.P. } & \multirow{2}{*}{$\begin{array}{l}\text { Ent. } \\
\text { Air } o_{F}\end{array}$} & \multirow{2}{*}{$\begin{array}{l}\text { Lvg. } \\
\text { Air }{ }^{\circ}{ }_{F}\end{array}$} & \multicolumn{2}{|c|}{$\overline{C F M}$} & \\
\hline & & & Meas。 & Corro & & & Meas. & Corr. & \\
\hline 920 & & & & & & & & & \\
\hline
\end{tabular}

Describe any defects or note acceptance

6. POWERED ROOF VENTILATIONS

Verify that damper closes when the ventilator motor is shut off.

\begin{tabular}{|c|c|}
\hline $\begin{array}{c}\text { Ventilator } \\
\text { E.P.N. }\end{array}$ & $\begin{array}{c}\text { Damper } \\
\text { Action }\end{array}$ \\
\hline 979 & \\
\hline
\end{tabular}

Describe any defects or note acceptance 
7. GRAVITY ROOF VENTILATORS

Record the following data:

a. Observe damper position of gravity roof ventilator when the normal ventilation system is running.

b. Shut off all motors of entire ventilation system and verify that gravity ventilator dampers close.

\begin{tabular}{|l|l|l|}
\hline $\begin{array}{l}\text { Ventilator E.P.N. } \\
\text { And Location }\end{array}$ & $\begin{array}{l}\text { Damper Action } \\
\text { Vent System-On }\end{array}$ & $\begin{array}{l}\text { Damper Action } \\
\text { Vent System-Off }\end{array}$ \\
\hline $961 \operatorname{Rm} 308$ & & \\
\hline 961 Stair \#6 & & \\
\hline $962 \operatorname{Rm} 101-$ West & & \\
\hline $962 \operatorname{Rm} 101-$ East & & \\
\hline $963 \operatorname{Corr} 30-$ North & & \\
\hline $963 \operatorname{Corr} 30-$ South & & \\
\hline $963 \operatorname{Rm} 312-$ West & & \\
\hline $963 \operatorname{Rm} 312-$ East & & \\
\hline
\end{tabular}

8. HOT PILOT CELLS VENTILATION DURTNG ACCESS

a. With the entire ventilation system shut off, note and mark the position of the exhaust damper operators for the open and closed position of the respective dampers.

b. Verify that the damper operating mechanisms work freely for the following dampers:

\begin{tabular}{|l|l|}
\hline Damper $\mathrm{E}_{2} \mathrm{P}_{2} \mathrm{~N}_{2}$ & Mechanism Action \\
\hline $957-\mathrm{AL}-1$ & \\
\hline $957-\mathrm{AL}-2$ & \\
\hline $957-\mathrm{HB}-1$ & \\
\hline $957-\mathrm{HB}-2$ & \\
\hline
\end{tabular}


8. (CONTINUED)

b. (contimued)'

\begin{tabular}{|l|l|}
\hline Damper E.P.N. & Mechanism Action \\
\hline $957-\mathrm{LB}-1$ & \\
\hline $957-\mathrm{LB}-2$ & \\
\hline $957-\mathrm{M}-1$ & \\
\hline $957-\mathrm{M}-2$ & \\
\hline $957-\mathrm{P}-1$ & \\
\hline $957-\mathrm{P}-2$ & \\
\hline
\end{tabular}

Describe any defects or note acceptance

c. Adjust the stops on the cell supply duct dampers so that the damper arm of each one is restrained at 10 degrees from the closed position.

d. Door and damper operation during cell access.

(1) As the air lock cell door is opened, door limit switches cause the cell supply duct dampers to close. The exhaust dampers automatically open in an attempt to maintain cell negative pressure.

(2) As an interior cell door is opened, door limit switches cause the cell supply duct damper (s) to close and the air lock cell supply duct dampers to open. The process cell exhaust dampers automatically open in an attempt to maintain cell negative pressure. Since the process cell pressures are more negative than that of the air lock, the air lock exhaust dampers automatically close.

e. With the complete normal ventilation system running, record the data required in the following table: 
HOT PILOT CELIS - VENTILATION DURTIG ACCESS

\begin{tabular}{|c|c|c|c|c|c|c|c|c|c|c|c|c|c|}
\hline \multirow{2}{*}{\multicolumn{2}{|c|}{$\mathrm{Cell}$}} & \multicolumn{3}{|c|}{ Before Access } & \multicolumn{9}{|c|}{ Access Door Open } \\
\hline & & \multirow{2}{*}{$\begin{array}{l}\text { Cell } \\
\text { S.P. }\end{array}$} & \multicolumn{2}{|c|}{ Air Source } & \multirow{2}{*}{$\begin{array}{l}\text { CelI } \\
\text { S.P. }\end{array}$} & \multicolumn{2}{|c|}{ Air Source } & \multicolumn{2}{|c|}{ Supply Damper } & \multicolumn{2}{|c|}{ Exhaust Damper } & \multirow{2}{*}{$\begin{array}{l}\text { Door Opng } \\
\text { CFM }\end{array}$} & \multirow{2}{*}{ Remarks } \\
\hline Title & $\mathrm{Rm}$ & & $\mathrm{Rm}$ & S.P. & & $\mathrm{Rm}$ & S.P. & E.P.N. & Position & E.P.N. & Position & & \\
\hline Air Lock & 135 & & 137 & & & 137 & & $\begin{array}{l}956-2- \\
\text { North } \\
956-2- \\
\text { South }\end{array}$ & & $\begin{array}{l}957-A I-1 \\
957-A I-2\end{array}$ & & & 1 \\
\hline High Bay & 136 & & 137 & & & 137 & & $956-2$ & & $\begin{array}{l}957-\mathrm{HB}-1 \\
957-\mathrm{HB}-2\end{array}$ & & & \\
\hline Low Bay & 133 & & 244 & & & 244 & & $\begin{array}{l}956-3- \\
\text { North } \\
\text { 956-3- } \\
\text { South }\end{array}$ & & $\begin{array}{l}957-L B-1 \\
957-L B-2\end{array}$ & & & $\begin{array}{l}\text { Verify } \\
\text { damper } \\
\text { EP \#957 } \\
\text {-SG in } \mathrm{Rm} \\
244 \text { opens. }\end{array}$ \\
\hline $\begin{array}{c}\text { Mechani- } \\
\text { cal }\end{array}$ & 246 & & 137 & & & 137 & & $956-1$ & & $\begin{array}{l}957-M-1 \\
957-M-2\end{array}$ & & & \\
\hline Pyro & 134 & & 137 & & & 137 & & $956-1$ & & $\begin{array}{l}957-P-1 \\
957-P-2\end{array}$ & & & \\
\hline $\begin{array}{l}\text { Low Bay } \\
(1) \\
\text { and }\end{array}$ & 133 & & 244 & & & 244 & & $\begin{array}{c}956-3 \\
\text { North } \\
956-3 \\
\text { South } \\
\end{array}$ & & $\begin{array}{l}957-I B-1 \\
957-L B-2\end{array}$ & & & \\
\hline Air Lock & 135 & & $\begin{array}{c}137 \\
-\end{array}$ & & & 137 & & $\begin{array}{l}956-2 \\
\text { North } \\
956-2 \\
\text { South }\end{array}$ & & $\begin{array}{l}957-A L-1 \\
957-A L-2\end{array}$ & & & \\
\hline
\end{tabular}

(1) With the Air Lock Cell access door open and an operating cell access door open at the same time, the Air Lock exhaust dampers should be closed and the operating cell exhaust dampers should be open.

(2) 6,000 cfm, minimum. 
9. HOT METALUURGICAL CELIS - VENTILATION DURING ACCESS

a. Adjust the stops on the cell supply duct dampers so that the damper arm of each one is restrained at 10 degrees from the closed position.

b. Door and damper operation during call access.

(a) As the air lock cell door is opened, door limit switches cause the cell supply duct dampers to close. The exhaust dampers automatically open in an attempt to maintain cell negative pressure.

(2) As an interior cell door is oponed, door limit switches cause the cell supply duct damper (s) to close and the air lock cell supply duct dampers to open. The exhaust dampers automatically open in an attempt to maintain cell negative pressure. Since the process cell pressures are more negative than that of the air lock, the air lock exhaust dampers automatically close.

c. With the normal ventilation system muning, record the data required in the following table on page 10 . 
HOT METALEURGICAL CELIS - VENTILATION DURING ACCESS

\begin{tabular}{|c|c|c|c|c|c|c|c|c|c|}
\hline \multicolumn{2}{|c|}{ Cell } & \multirow{3}{*}{$\begin{array}{c}\text { Before Access } \\
\text { Cell } \\
\text { S.P. } \\
\end{array}$} & \multicolumn{7}{|c|}{ Access Door Open } \\
\hline & & & $\overline{C e 11}$ & Supply & Damper & Exhaust & Damper & Door Opng & Remarks \\
\hline Title & $\mathrm{Rm}$ & & S.P. & EPN & Position & EPN & Position & CFM (2) & \\
\hline Air Iock & 141 & & & $956-6$ & & $\begin{array}{l}\text { 953-AI- } \\
\text { West } \\
\text { 953-AL- } \\
\text { East }\end{array}$ & & & \\
\hline Fabrication & 140 & & & $\begin{array}{r}956-5 \\
\text { West } \\
956-5 \\
\text { East }\end{array}$ & & $\begin{array}{l}953-\mathrm{F}- \\
\text { West } \\
953-\mathrm{F}- \\
\text { East }\end{array}$ & & & \\
\hline Preparation & 142 & & & $956-5$ & & $\begin{array}{l}953-P- \\
\text { North } \\
953-P- \\
\text { South }\end{array}$ & & & \\
\hline $\begin{array}{l}\text { Fabrication } \\
\text { (1) } \\
\text { and }\end{array}$ & 140 & & & $\begin{array}{r}956-5 \\
\text { West } \\
956-5 \\
\text { East }\end{array}$ & & $\begin{array}{l}953-F- \\
\text { West } \\
953-F- \\
\text { East }\end{array}$ & & & \\
\hline Air Lock & 141 & & & $956-6$ & & $\begin{array}{c}953-A L \\
\text { West } \\
\text { 953-AL- } \\
\text { East }\end{array}$ & & & \\
\hline
\end{tabular}

(1) With the Air Lock Cell access door open and an operating cell access door open at the same time, the Air Lock exhaust dampers should be closed and the operating cell exhaust dampers should be open.

(2) 6,000 cfm, minimum.

Dericritie any defocts or note uccoptance 
10. TRUCK LOCK - (Rm 138)

a. Record static pressure in the Low Level Canyon (Rm 146). inch w.g.

b. With the normal ventilation system running, open the outside door of the truck lock.

(1) Verify that as the door opens, door limit switches cause the dampers in the truck lock supply duct to close.

(2) Record the static pressure in the Low Level Canyon. inch w.g.

(3) Slight or no change in the pressure of $\mathrm{Rm} 146$ indicates that damper E.P. No. 983 is functioning satisfactorily. Verify.

11. CASK HANDTING - (Rm 137)

a. Record the static pressure in the cask handling.___inch w.g.

b. With the normal ventilation system munning, and the truck lock outside door open, open the door between the truck lock and cask handling.

(1) Record the static pressure in the cask handling. inch w.g.

(2) Verify that the supply duct damper, E.P.N. 956, modulated toward the closed position.

c. Close both equipment doors.

12. HOT PIIOT CELL GALIERIES SUPPLY

a. Record the static pressure in $\mathrm{Rm} 244 . \ldots$ inch w.g.

b. With the normal ventilation system running, open the outside door of stair 8 and doors of rooms 131,244, and 311 leading to stair 8 . 


\section{2. (CONTINUED)}

b. (continued)

(1) Record the static pressure in Rm 244 . inch w.g.

(2) Verify that the supply duct damper E.P. No. 956-4 modulated toward the closed position

c. Close all doors.

13. HOT METALLURGICAL CELL GAIIERY SUPPLY (Rm 139)

a. Record the static pressure in Rm 139__ inch w.g.

b. With the normal ventilation system running, open the outside personnel door.

(1) Record the static pressure in $\mathrm{Rm} 139$ _ inch w.g.

(2) Verify that the supply duct dampers E.P.N. 956-7 and 956-8 modulated toward the closed position

c. Close door.

d. With the normal ventilation system running, open the doors common with the cask handling room. ( $\mathrm{Rm}$ 137).

(1) Record the static pressure in Rm 139 inch w.g.

(2) Since the pressures in rooms 139 and 137 are essentially the same, opening the common doors should have negligible effect on the supply dompers of either space. Note and describe any change in the position of supply dampers E.P.N. 956-7 and 956-8 for Room 139 Note and describe any change in the position of supply damper E.P.N. 956 for Room 137

e. Close doors. 
14. ZONE I AND II EXXAUST FANS

a. With the normal ventilation system running, record the following exhaust fan data:

\begin{tabular}{|c|c|c|c|c|c|c|c|c|c|}
\hline Fan & Motor & Speed & Bearing & Vibration & Inlet & Diff S.P. & & Corr. $\mathrm{Vs}$ & lues (3) \\
\hline EPN & Amp. & RPM & $\operatorname{Temp}(1)$ & Displmt. (2) & Temp & In. w.g. & CFM] & S.P. & CFM \\
\hline 971 & & & & & & & & & \\
\hline 972 & & & & & & & & & \\
\hline 973 & & & & & & & & & \\
\hline 974 & & & & & & & & & \\
\hline 75 & & & & & & & & & \\
\hline
\end{tabular}

(1) Normal bearing munning temperature should be approximately $150 \mathrm{~F}$.

(2) The peak-to-peak amplitude of vibration of the installed fan, when measured on the shaft or bearing caps in the horizontal and vertical planes at the rated flow, static pressure, and speed, shall not exceed 0.0002 inches. Displacement may be measured by an International Research and Development Analyzer or similar portable instrument.

(3) Correct the static pressure and flow to $70 \mathrm{~F}$ and 29.92" Hg.

b. With one fan running, check the fan performance against the submitted fan performance curve by regulating the flow through the radial inlet damper. Open filter room and corridor doors to the outside prior to testing. A minimum of four points should be plotted. Correct the static pressure and flow to $70 \mathrm{~F}$ and $29.92^{\prime \prime} \mathrm{Hg}$. Return damper settings to normal. 
14. (CONTINUED)

b. (continued)

\begin{tabular}{|c|c|c|c|c|c|c|c|c|}
\hline \multicolumn{9}{|c|}{ Measured Values } \\
\hline \multirow{2}{*}{$\begin{array}{l}\text { Fan } \\
\text { E'PN }\end{array}$} & \multicolumn{2}{|c|}{ (1) } & \multicolumn{2}{|c|}{ (2) } & \multicolumn{2}{|c|}{ (3) } & \multicolumn{2}{|c|}{ (4) } \\
\hline & S.P. & CFM & S.P. & CFM & S.P. & $\mathrm{CFM}$ & S.P. & $\mathrm{CFM}$ \\
\hline 971 & & & & & & & & \\
\hline 972 & & & & & & & & \\
\hline 973 & & & & & & & & \\
\hline 974 & & & & & & & & \\
\hline 975 & & & & & & & & \\
\hline
\end{tabular}

Describe any defects or note acceptance

\begin{tabular}{|c|c|c|c|c|c|c|c|c|}
\hline \multicolumn{9}{|c|}{ Corrected Values } \\
\hline \multirow{2}{*}{$\begin{array}{l}\text { Fan } \\
\text { EPN } \\
\end{array}$} & \multicolumn{2}{|c|}{ (1) } & \multicolumn{2}{|c|}{ (2) } & \multicolumn{2}{|c|}{ (3) } & \multicolumn{2}{|c|}{ (4) } \\
\hline & S.P. & $\mathrm{CFM}$ & S.P. & CFM & S.P. & CFM & S.P. & CFM \\
\hline 971 & & & & & & & & \\
\hline 972 & & & & & & & & \\
\hline 973 & & & & & & & & \\
\hline 974 & & & & & & & & \\
\hline 975 & & & & & & & & \\
\hline
\end{tabular}

Describe any defects or note acceptance. 
14. (CONIINUED)

c. With the normal ventilation system munning, test the discharge damper of each fan for leak tightness by stopping each one individually and measuring damper leakage.

Leakage shall not exceed $5 \%$ of the rated flow at the rated differential pressure. Correct flow to $70 \mathrm{~F}$ and $29.92 \mathrm{l} \mathrm{Hg}$. Verify that damper closes satisfactorily when fan is stopped.

\begin{tabular}{|l|l|l|l|l|}
\hline Fan & Rated Flow & \multicolumn{2}{|c|}{ Discharge Damper Leakage } & Damper \\
EPN & CFM & Measured & Corrected & Operation \\
\hline 971 & & & & \\
\hline 972 & & & & \\
\hline 973 & & & & \\
\hline 974 & & & & \\
\hline 975 & & & & \\
\hline
\end{tabular}

\section{ZONE III EXHAUST FANS}

a. With the normal ventilation system running, record the following exhaust fan data:

\begin{tabular}{|c|c|c|c|c|c|c|c|c|}
\hline $\begin{array}{l}\text { Fan } \\
\text { EPN }\end{array}$ & $\begin{array}{l}\text { Motor } \\
\text { Amp. }\end{array}$ & $\begin{array}{l}\text { Speed } \\
\text { RPM }\end{array}$ & $\begin{array}{l}\text { Bearing } \\
\text { Temp(1) }\end{array}$ & $\begin{array}{l}\text { Vibration } \\
\text { Displm. (2) }\end{array}$ & \begin{tabular}{|l} 
Inlet \\
Temp
\end{tabular} & $\begin{array}{l}\text { Diff S.P } \\
\text { In. W.g. }\end{array}$ & CFM & $\begin{array}{c}\text { Corr.Values (3) } \\
\text { S.P. CFM }\end{array}$ \\
\hline 976 & & & & & & & & \\
\hline 977 & & & & & & & & \\
\hline
\end{tabular}

(1) Normal bearing running temperature should be approximately $150 \mathrm{~F}$. 
15. (CONTINUED)

a. (continued)

(2) The peak-to-peak amplitude of vibration of the installed fan, when measured on the shaft or bearing caps in the horizontal and vertical planes at the rated flow, static pressure, and speed, shall not exceed 0.0002 inches. Displacement may be measured by an International Research and Development Analyzer or similar portable instrument.

(3) Correct the static pressure and flow to $70 \mathrm{~F}$ and 29.92" $\mathrm{Hg}$.

b. With one fan running, check the fan performance against the submitted fan performance curve by regulating the flow through the radial inlet damper. Open filter room and corridor doors to the outside prior to testing. A minimum of four points should be plotted. Correct the static pressure and flow to $70 \mathrm{~F}$ and $29.92 \mathrm{l} \mathrm{Hg}$. Return damper settings to normal.

\begin{tabular}{|c|c|c|c|c|c|c|c|c|}
\hline \multirow{3}{*}{$\begin{array}{l}\text { Fan } \\
\text { EPN }\end{array}$} & \multicolumn{8}{|c|}{ Measured Values } \\
\hline & \multicolumn{2}{|c|}{ (1) } & \multicolumn{2}{|c|}{ (2) } & \multicolumn{2}{|c|}{ (3) } & \multicolumn{2}{|c|}{ (4) } \\
\hline & S.P. & CFM & S.P. & CFM & S.P. & $\mathrm{CFM}$ & S.P. & $\mathrm{CFM}$ \\
\hline 976 & & & & & & & & \\
\hline 977 & & & & & & & & \\
\hline
\end{tabular}

Describe any defects or note acceptance

\begin{tabular}{|l|c|c|c|c|c|c|c|c|}
\hline \multirow{3}{*}{$\begin{array}{l}\text { Fan } \\
\text { EPN }\end{array}$} & \multicolumn{7}{|c|}{ Corrected Values } & \multicolumn{2}{|c|}{ (2) } & \multicolumn{2}{|c|}{ (3) } & \multicolumn{2}{|c|}{$(4)$} \\
\hline & S.P. & CFM & S.P. & CFM & S.P. & CFM & S.P. & CFM \\
\hline 976 & & & & & & & & \\
\hline 977 & & & & & & & & \\
\hline
\end{tabular}

Describe any defects or note acceptance 
19. (CONTINUED)

c. With the normal ventilation system running, test the intake plenum dampers of each fan by stopping each one individually and measuring damper leakage. Leakage shall not exceed $5 \%$ of the rated flow at the rated differential pressure. Correct flow to $70 \mathrm{~F}$ and $29.92 "$ Hg.

\begin{tabular}{|l|c|l|l|}
\hline Fan & Rated Flow & \multicolumn{2}{|c|}{ Discharge Damper Leakage } \\
\cline { 3 - 4 } EPN & CFM & Measured & Corrected \\
\hline 976 & & & \\
\hline 977 & & & \\
\hline
\end{tabular}

Describe any defects or note acceptance

\section{EMERGENCY POWER OPERATION}

a. With the normal ventilation system running, simulate a complete loss of normal power.

b. Verify that one of the Zone II exhaust fans starts on emergency power

c. Verify that one of the Zone I exhaust fans starts on emergency power

d. Verify that the cell and room negative pressures do not exceed the specified numerical values by more than $25 \%$

Verify that the cell negative pressures are not less than the specified numerical values by more than $25 \%$

e. Adjust the stops of the proper supply duct dampers as required. Verify that the relief dampers EPN 982 on the bottom of the roof duct are actuated 
With the complete ventilation system running, verify that upon simulated instrument air failure to the radial inlet damper of each fan that the operator rod is clamped in the last position of control.

\begin{tabular}{|l|c|}
\hline $\begin{array}{l}\text { Fan } \\
\text { EPN }\end{array}$ & $\begin{array}{c}\text { Damper Operator } \\
\text { Rod Clamped }\end{array}$ \\
\hline 971 & \\
\hline 972 & \\
\hline 973 & \\
\hline 974 & \\
\hline 975 & \\
\hline 976 & \\
\hline 977 & \\
\hline
\end{tabular}

Describe any defects or note acceptance

\section{INSTALEED HIGH-EFFTCIENCY FIITER TESTS}

a. Upon completion of high-efficiency filter installation and after balancing of the process area ventilation system, the filters shall be tested by the Commission.

b. Testing will be done by means of a portable DOP test unit.

c. No leakage will be permitted around the filter unit gaskets.

d. Filters shall have a minimum efficiency of $99.95 \%$, i.e., the penetration of 0.3 micron diameter, homogeneous particles of dioctyl phthalate (DOP) particles shall not exceed $0.05 \%$. Pressure drop shall not exceed 1 inch of water.

e. Inspect placement of filters prior to testing. 
18. (CONTINUED)

f. Verify that the filters are acceptable and note in the following tables:

(1)

\begin{tabular}{|c|c|c|c|c|}
\hline \multicolumn{5}{|c|}{ Process Area Vent. Supply Plenum } \\
\hline \multirow{2}{*}{$\begin{array}{l}\text { Vertical } \\
\text { Row } \\
\text { No. } \\
\end{array}$} & \multicolumn{4}{|c|}{ Horizontal Row No. } \\
\hline & $\begin{array}{c}\text { East } \\
1\end{array}$ & 2 & 3 & $\begin{array}{c}\text { West } \\
4\end{array}$ \\
\hline 1 (Top) & & & & \\
\hline 2 & & & & \\
\hline 3 & & & & \\
\hline 4 (Bottom) & & & & \\
\hline
\end{tabular}

Describe any defects or note acceptance $\because$

(2)

\begin{tabular}{|c|c|c|c|c|c|}
\hline \multicolumn{5}{|c|}{ Zone I Filter Room No. 9 } \\
\hline $\begin{array}{c}\text { Vertical } \\
\text { Row } \\
\text { No. }\end{array}$ & $\begin{array}{c}\text { Horizontal Row No. } \\
1\end{array}$ & 2 & 3 & 4 & $\begin{array}{c}\text { North } \\
\text { (Top) }\end{array}$ \\
\cline { 2 - 6 } & & & & & \\
\hline 2 & & & & & \\
\hline 3 & & & & & \\
\hline 4 (Bottom) & & & & & \\
\hline
\end{tabular}

Describe any defects or note acceptance 
18. (CONTINUED)

f. Verify that the filters are acceptable and note in the following tables: (continued)

(3)

\begin{tabular}{|c|c|c|c|c|c|}
\hline \multicolumn{5}{|c|}{ Zone I Filter Room No. 10 } \\
\hline $\begin{array}{c}\text { Vertical } \\
\text { Row } \\
\text { No. }\end{array}$ & $\begin{array}{c}\text { South } \\
1\end{array}$ & 2 & 3 & 4 & $\begin{array}{c}\text { North } \\
5\end{array}$ \\
\hline 1 (Top) & & & & & \\
\hline 2 & & & & & \\
\hline 3 & & & & & \\
\hline 4 (Bottom) & & & & & \\
\hline
\end{tabular}

Describe any defects or note acceptance

(4)

\begin{tabular}{|c|c|c|c|c|c|c|c|c|}
\hline \multicolumn{7}{|c|}{ Zone II Filter Room No. 6 } \\
\hline $\begin{array}{c}\text { Vertical } \\
\text { Row } \\
\text { No. }\end{array}$ & $\begin{array}{c}\text { South } \\
1\end{array}$ & 2 & 3 & 4 & 5 & 6 & 7 & $\begin{array}{c}\text { North } \\
8\end{array}$ \\
\hline 1 (Top) & & & & & & & & \\
\hline 2 & & & & & & & & \\
\hline 3 & & & & & & & & \\
\hline 4 (Bottom) & & & & & & & & \\
\hline
\end{tabular}

Describe any defects or note acceptance 
18. (CONTINUED)

f. Verify that the filters are acceptable and note in the following tables: (continued)

(5)

\begin{tabular}{|c|c|c|c|c|c|c|c|c|c|}
\hline \multicolumn{10}{|c|}{ Zone II Filter Room No. } \\
\hline $\begin{array}{c}\text { Vertical } \\
\text { Row } \\
\text { No. }\end{array}$ & $\begin{array}{c}\text { South } \\
1\end{array}$ & 2 & 3 & 4 & 5 & 6 & 7 & 8 & \begin{tabular}{c} 
North \\
\hline 1 (Top)
\end{tabular} \\
\hline 2 & & & & & & & & & \\
\hline 3 & & & & & & & & & \\
\hline 4 (Botton) & & & & & & & & & \\
\hline
\end{tabular}

Describe any defects or note acceptance

(6)

\begin{tabular}{|c|c|c|c|c|c|}
\hline \multicolumn{5}{|c|}{ Zone III Filter Room 313 } \\
\hline $\begin{array}{c}\text { Vortical } \\
\text { No. }\end{array}$ & \multicolumn{4}{|c|}{ Horizontal Row No. } \\
\hline 1 & 1 South & 2 & 3 & 4 & 5 \\
\hline 2 (Top) & & & & & \\
\hline 3 & & & & & \\
\hline 4 (Bottom) & & & & & \\
\hline
\end{tabular}

Describe any defects or note acceptance 
18. (CONTINUED)

f. Verify that the filters are acceptable and note in the following tables: (continued)

(7)

\begin{tabular}{|c|c|c|c|c|c|}
\hline \multicolumn{6}{|c|}{ Zone III Filter Room 314 } \\
\hline $\begin{array}{c}\text { Vertical } \\
\text { Row } \\
\text { No. }\end{array}$ & $\begin{array}{c}\text { South } \\
1\end{array}$ & 2 & 3 & 4 & \begin{tabular}{c} 
North \\
\hline 1 (Top)
\end{tabular} \\
\hline 2 & & & & & \\
\hline 3 & & & & & \\
\hline 4 (Bottom) & & & & & \\
\hline
\end{tabular}

Describe any defects or note acceptance

(8)

\begin{tabular}{|c|c|c|c|c|c|}
\hline \multicolumn{5}{|c|}{ Fabrication Cell Room 140 } \\
\hline Wall & \multicolumn{5}{|c|}{ Position } \\
\hline & South & Middle & North & North & Middle \\
\hline West & & & & & \\
\hline East & & & & & \\
\hline
\end{tabular}

Describe any defects or note acceptance 
18. (CONTINUED)

f. Verify that the filters are acceptable and note in the following tables: (continued)

(9)

\begin{tabular}{|l|l|l|l|l|l|}
\hline Wall & \multicolumn{5}{|c|}{ Air Lock Cell Room 141 } \\
\hline & South & North & West & East & East \\
\hline West & & & South \\
\hline North & &
\end{tabular}

Describe any defects or note acceptance

(10)

\begin{tabular}{|l|l|l|l|l|l|l|}
\hline \multirow{3}{*}{ Wall } & \multicolumn{5}{|c|}{ Preparation Cell Room 142 } \\
\cline { 2 - 6 } & West & Middle & East & East & Middle & West \\
\hline \multirow{2}{*}{ North } & & & & & & \\
\hline
\end{tabular}

Describe any defects or note acceptance

(11) DECONTAMINATION STALL - ROOM 138

Describe any defects or note acceptance 
18. (CONTINUED)

f. (Continued)

(12) DECONTAMINATION HOODS - ROOM 147

North

South

Describe any defects or note acceptance

19. TESTING OF PROCESS AREA VENTIIATION SYSTIEM WITNESSED BY:

\begin{tabular}{ccc} 
& For & Date \\
\hline For & Date \\
\hline For & Date \\
\hline
\end{tabular}




\section{APPENDIX B}

\section{ADMINISTRATION AREA VENTIIIATION ACCEPTANCE TEST PROCEDURE}

1. SUPPLY FAN EPN 903

a. Test Procedure shall not be performed until system balancing is complete.

b. With the normal ventilation system muning, record the following supply fan data:

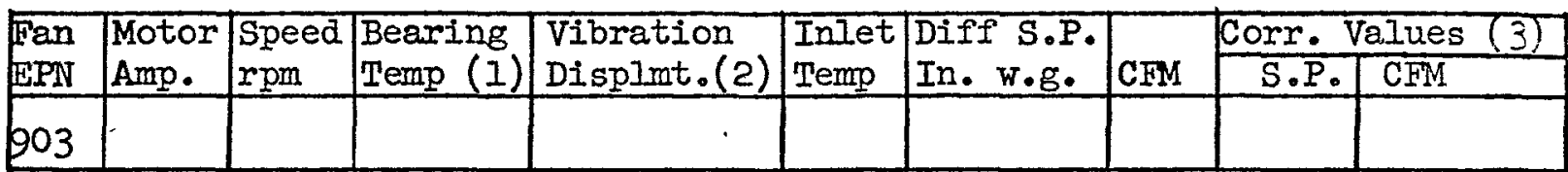

(1) Normal bearing running temperature should be approximately $150 \mathrm{~F}$.

(2) The peak-to-peak amplitude of vibration of the installed fan, when measured on the shaft or bearing caps in the horizontal and vertical planes at the rated flow, static pressure, and speed, shall not exceed 0.002 inches. Displacement may be measured by an International Research and Development Analyzer or similar portable instrument.

(3) Correct the static pressure and flow to $70 \mathrm{~F}$ and $29.92^{\prime \prime} \mathrm{Hq}$.

c. Check the fan performance against the submitted fan performance curve by regulating the flow through the radial inlet damper. A minimm of four points should be plotted. Correct the static pressure and flow to $70 \mathrm{~F}$ and $29.92 " \mathrm{Hq}$. Return the damper setting to normal.

\begin{tabular}{|c|c|c|c|c|c|c|c|c|}
\hline & \multicolumn{8}{|c|}{ Corrected Values } \\
\hline & \multicolumn{2}{|c|}{ (1) } & \multicolumn{2}{|c|}{ (2) } & \multicolumn{2}{|c|}{ (3) } & \multicolumn{2}{|c|}{ (4) } \\
\hline $\begin{array}{l}\text { Fan } \\
\text { EPN }\end{array}$ & S.P. & $\mathrm{CFM}$ & S.P. & CFM & S.P. & CFM & S.P. & CFM \\
\hline & & & & & & & & \\
\hline
\end{tabular}

Describe any defects or note acceptance

\begin{tabular}{|l|c|l|l|l|l|l|l|l|}
\hline & \multicolumn{2}{|c|}{ (1) } & \multicolumn{2}{c|}{ (2) } & \multicolumn{2}{c|}{ (3) } & \multicolumn{2}{c|}{ (4) } \\
\hline Fan & S.P. & CFM & S.P. & CFM & S.P. & CFM & S.P. & CFM \\
\hline & & & & & & & & \\
\hline
\end{tabular}

Describe any defects or note acceptance 
2. SUPPLY UNIT AIR FIITER - EPN 903-D

With normal ventilation system running, record the pressure drop across the filter. With clean media, a pressure drop greater than 0.2 inch $\mathrm{w} . \mathrm{g}$. shall not be acceptable. Correct the static pressure to $70 \mathrm{~F}$ and $29.92^{\prime \prime} \mathrm{Hq}$.

Measured Diff. S.P. inch w.g. Corr. Diff. S.P. inch $w \cdot \Xi$.

Describe any defects or note acceptance

\section{STPAM SUPPLY UNIT HEATING COII AND ZONE REHEAT COIIS}

a. Each coil section may be tested separately to avoid excessive building temperature.

b. The control valve for the coil being tested shall be open and full steam flow shall be on the coil.

c. Record the following data:

(1) With both ventilation systems ruming, measure and record the dry bulb temperature of air entering and leaving the coil and verify that the heating capacity is at least equal to the manufacturer's rating.

(2) Measure and record the static pressure drop across each coil and compare with the manufacturer's rated drop. Correct the static pressure and flow to $70 \mathrm{~F}$ and $29.92^{\prime \prime} \mathrm{Hq}$.

(3) Verify that all traps function properly.

\begin{tabular}{|c|c|c|c|c|c|c|c|c|c|c|}
\hline \multirow{3}{*}{$\begin{array}{l}\text { COII } \\
\text { EPN }\end{array}$} & \multicolumn{2}{|c|}{ Rated } & \multicolumn{8}{|c|}{ Measured } \\
\hline & \multirow{2}{*}{$\begin{array}{l}\text { Capacity } \\
\text { BTU/hr }\end{array}$} & \multirow{2}{*}{$\begin{array}{l}\text { Diff. } \\
\text { S.P. }\end{array}$} & \multirow{2}{*}{\multicolumn{2}{|c|}{\begin{tabular}{l|l} 
Diff. S.P. \\
Meas. Corr.
\end{tabular}}} & \multirow{2}{*}{$\begin{array}{l}\text { Ent. } \\
\text { Air F }\end{array}$} & \multirow{2}{*}{$\begin{array}{l}\text { IVI. } \\
\text { Air F }\end{array}$} & \multicolumn{2}{|c|}{ CFM } & \multirow{2}{*}{$\begin{array}{l}\text { Capacity } \\
\text { BTU/hr }\end{array}$} & \multirow[b]{2}{*}{ TRAPS } \\
\hline & & & & & & & Meas. & Corr. & & \\
\hline $903 c$ & & & & & & & & & & \\
\hline 904 & & & & & & & & & & \\
\hline & & & & & & & & & & \\
\hline 905 & & & & & & & & & & \\
\hline & & & & & & & & & & \\
\hline 900 & & & & & & & & & & \\
\hline 907 & & & & & & & & & & \\
\hline
\end{tabular}

Describe any defects or note acceptance 
4. WATER CHITIER

a. With the supply unit and water chiller running determine the cooling capacity of the unit by setting the preheat coil thermostat at a temperature above the thermostatic set point of the chilled water coil.

b. Record the following data:

(1) Measure and record the $d r y$ bulb temperature of air entering and leaving the coil and verify that the cooling capacity is at least equal to the manufacturer's rating.

(2) Measure and record the static pressure drop across the cooling coil and compare with the manufacturer's rated drop. Correct static pressure and flow to $70 \mathrm{~F}$ and $29.92^{\prime \prime} \mathrm{Hq}$.

(3) Measure and record the temperatures of the chilled water supply, chilled water return, condenser water supply, and condenser water discharge.

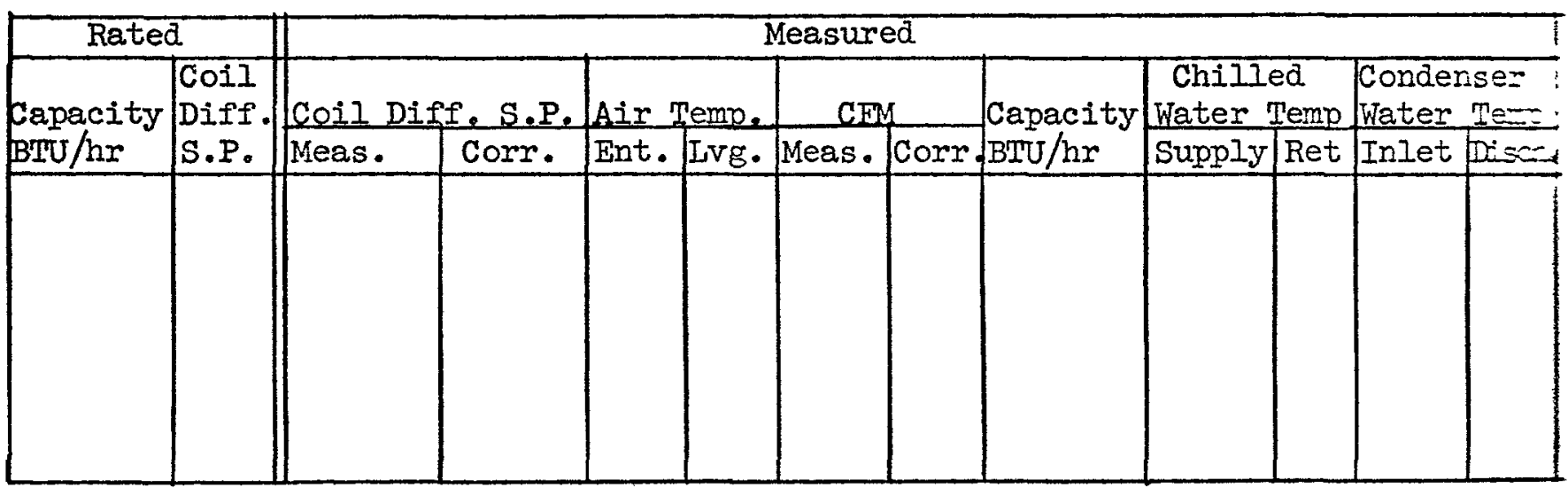

c. Verify that the condenser water control valve opened when the water chiller was started

d. Verify that the condenser water control valve closed when the water chiller was stopped

e. Describe any defects or note acceptance

5. POWERED WALI AND ROOF VENTIIATORS

Verify that the dampers close when the ventilaor is shut off.

\begin{tabular}{|c|r|}
\hline $\begin{array}{c}\text { Ventilator } \\
\text { EPN }\end{array}$ & $\begin{array}{r}\text { Damper } \\
\text { Action }\end{array}$ \\
\hline 979 & \\
\hline 980 & \\
\hline
\end{tabular}


5. (CONTINUED)

Describe any defects or note acceptance

6. GRAVITY ROOF VENTTIATIOR

a. Observe damper position of gravity roof ventilator when the normal ventilation system is running.

b. Shut off the entire ventilation system and verify that the damper closes.

\begin{tabular}{|l|l|l|}
\hline $\begin{array}{l}\text { Ventilator } \\
\text { Eri and Location }\end{array}$ & $\begin{array}{l}\text { Damper Action } \\
\text { Vent System-on }\end{array}$ & $\begin{array}{l}\text { Damper Action } \\
\text { Vent System-Off }\end{array}$ \\
\hline 960 stair \# 2 & & \\
\hline
\end{tabular}

7. TESTING OF ADMINISTRATION AREA VENTIIATION SYSTFM WITNESSED BY:

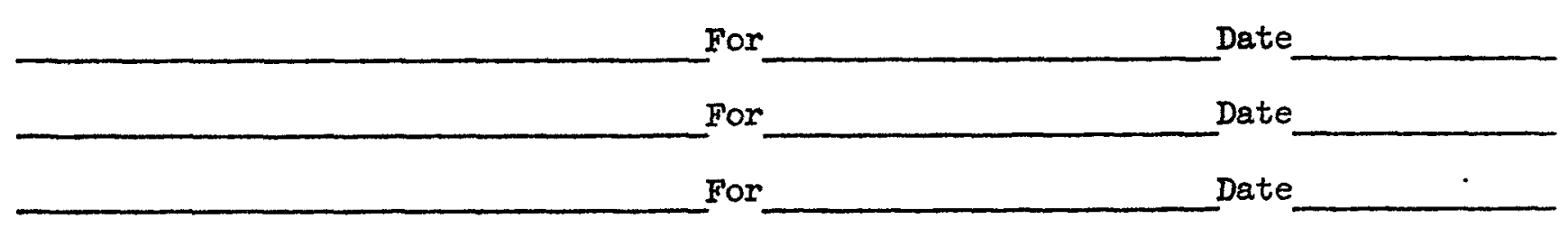




\section{APPENDIX "C"}

PRESSURE PIPING COMPLETION RECORD

\begin{tabular}{|l|l|l|l|l|l|}
\hline AREA NO. & BUILOINO ORFACILITYNO. & LATION \\
\hline
\end{tabular}

DESCR:PTION OP PIPING IF NECESSARY USE ADOITIONAL SHEETSI

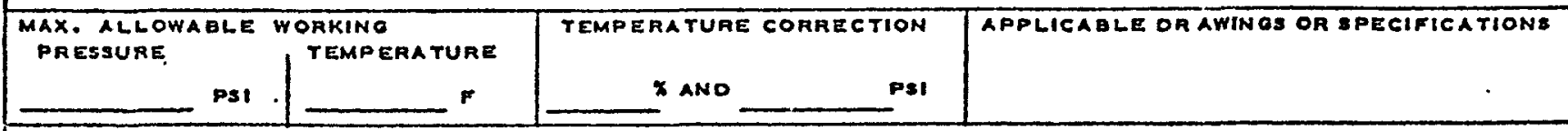

PIPE MATERIAL sPECIFICATIONS. LASTM, ETC.l

\begin{tabular}{|c|c|c|c|}
\hline ORIGINAL CONBTRUCTION & MODIFICATION & REPAIR & JOB ORDER IPROJECT NO..CONTRACT NO.. OR M.O.NO.J \\
\hline
\end{tabular}

FABRICATOR (NAME OF PLANT FORCE FACILITY, COST PLU3 FF CONTRACTOR, LUMP SUM CONTRACTORI

WELDINO DONE IN ACGORDANCE WITH QUALIFIEO WELDING PFOCEOURE HOS.

\section{FILLER MATERIAL (ASTM ANO TYPE)}

WELDERS OR WELDINO OPERATORS WELO IDENTIFICATION NO. AND OATE LA3T QUALIFIED

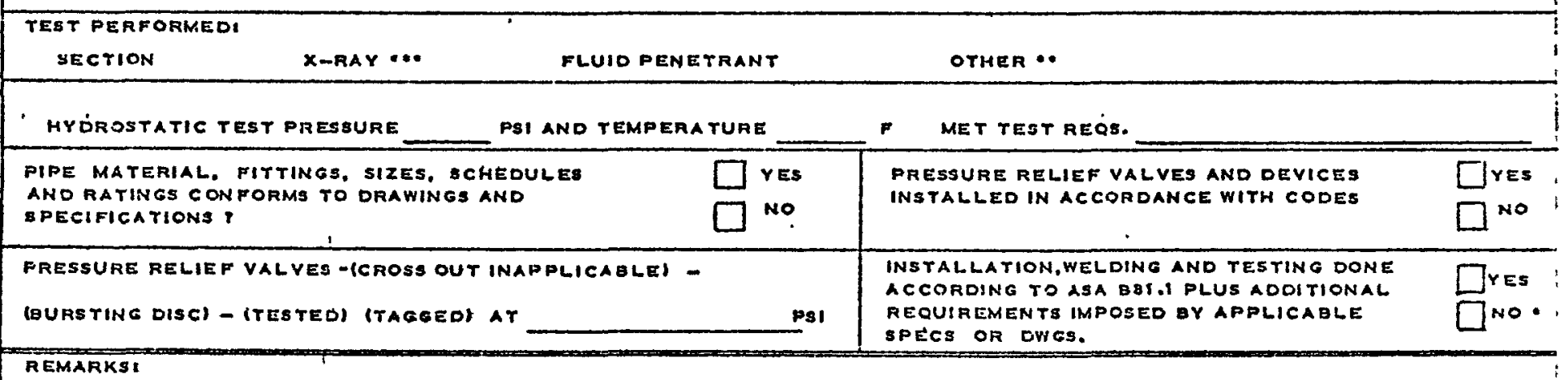

REMARKSI

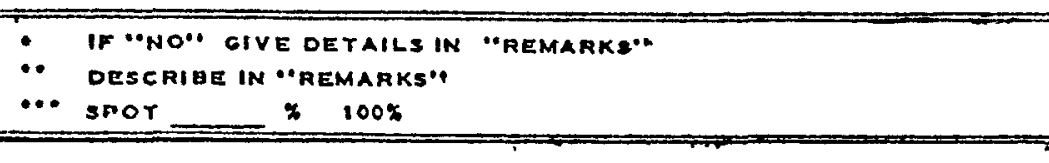

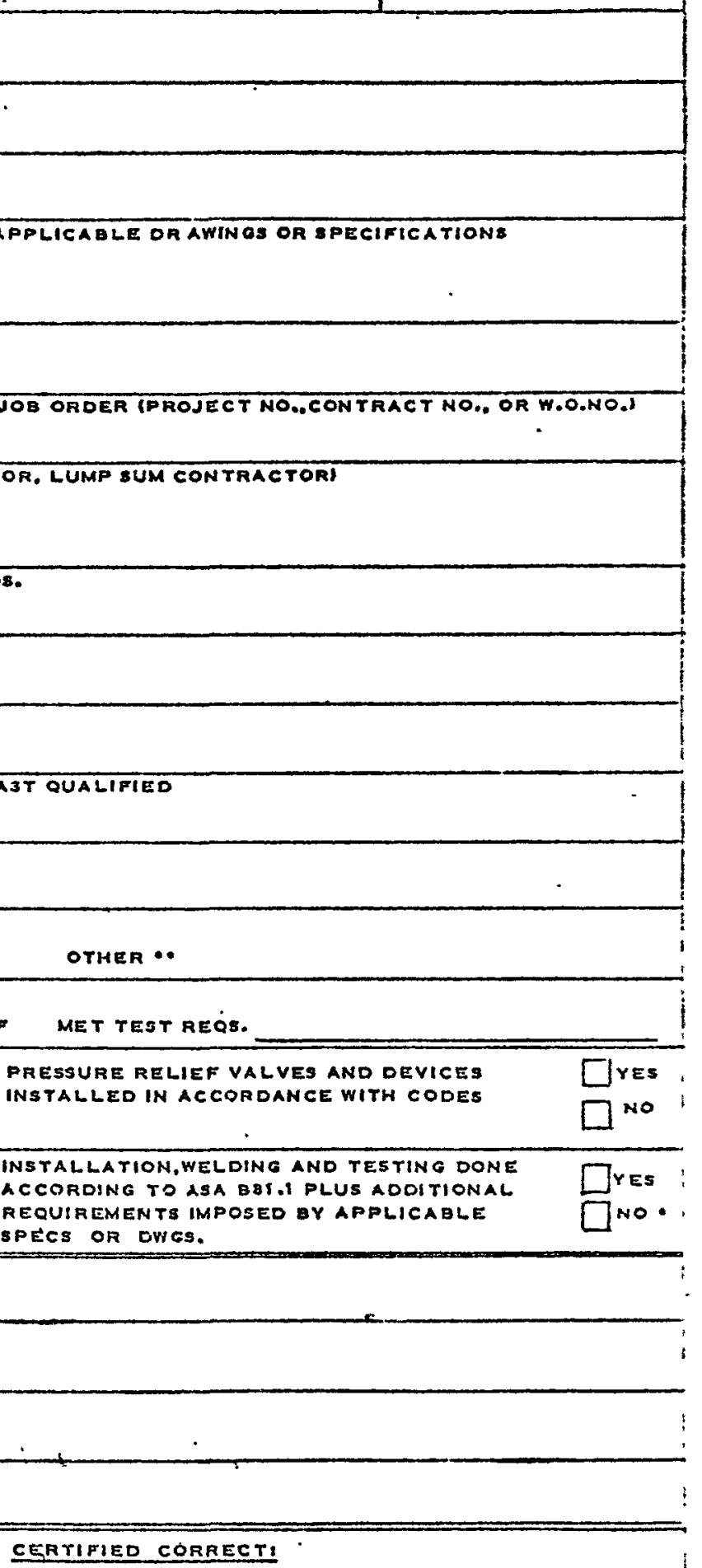

FABRICATOR

TESTS WITNESSED QY

INSPECTOR

REVIEWEO ANDAPPROYEO BY:

ENOINETR

$\because \ldots$ 